639.313

F 2 brfi

2000

C. 2

$\therefore$

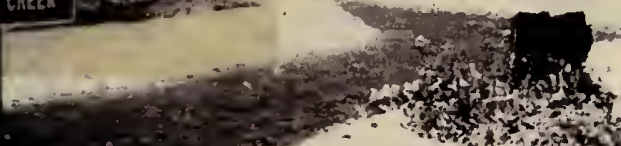

$-1$

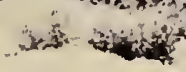

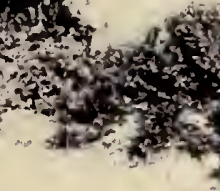

\title{
Blackfoot River
}

Fisheries Inventory,

Monitoring and

Restoration

Report 2000 stare oncmimerrs couleo Whortana Fish. 116092000 MNTANA STATE LIBRARY HELENA, E. 6th AVE.
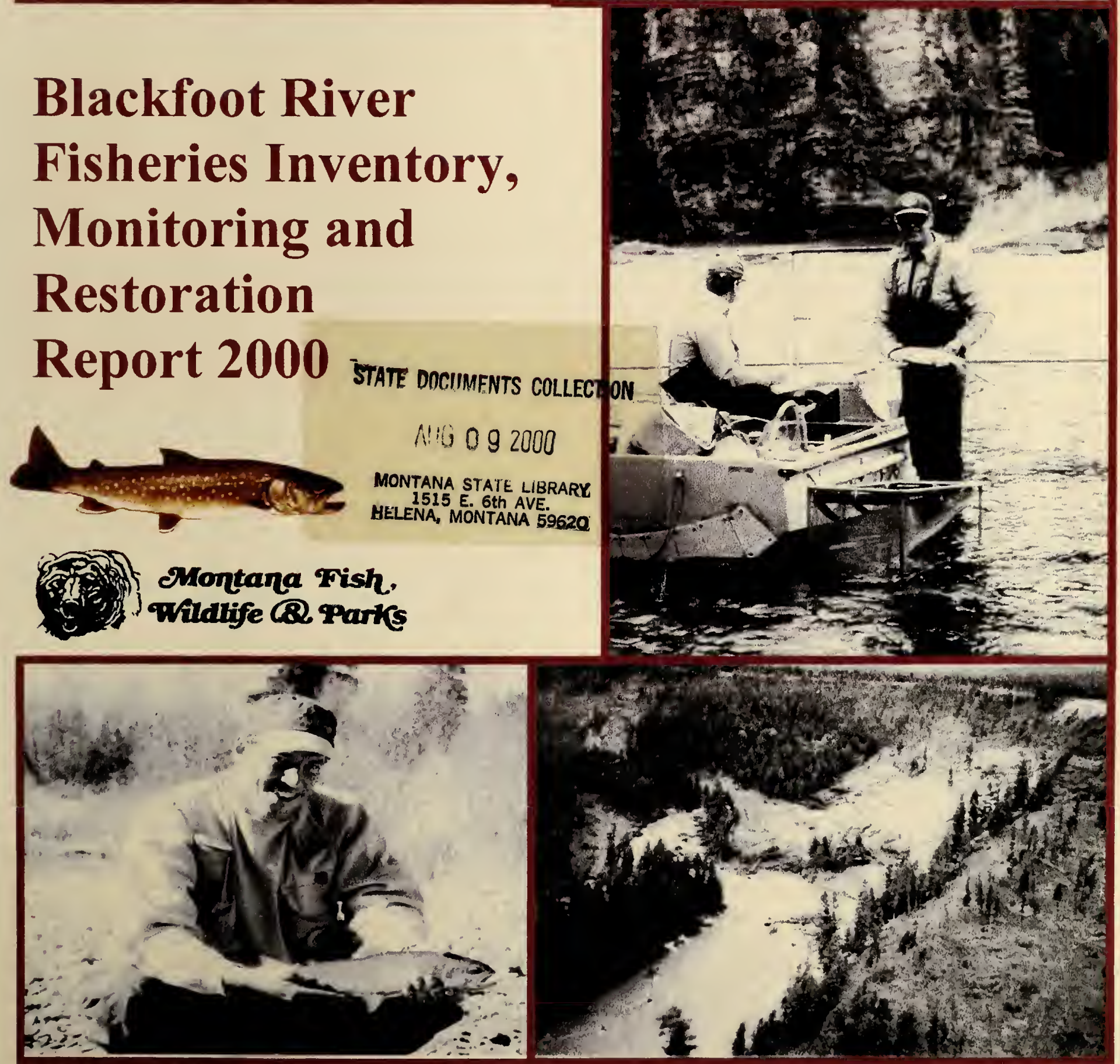

EA, MONTANA 59620 


\title{
Blackfoot River \\ Fisheries Inventory, Monitoring and Restoration Report 2000
}

\author{
Ron Pierce and Craig Podner \\ Montana Fish, Wildlife and Parks \\ 3201 Spurgin Road \\ Missoula, Montana 59804
}

April 2000 



\begin{abstract}
In order to expand native fish recovery in the Blackfoot River watershed, we redirected fish population investigations from the restoration program in lower Blackfoot River basin to fish and habitat data collection in the upper basin. The upper basin effort included baseline tributary inventories, problem identification and monitoring of five historic fish population survey sections last sampled in 1988. Tributary fish population inventories found a widespread distribution of westslope cutthroat trout (Onchorynchus clarki lewisi) with a high degree of genetic for the upper Blackfoot River drainage upstream of Nevada Creek. We found no pure rainbow trout (O. mykiss) in any of the upper river samples. Bull trout (Salvelinus confluentus) were at very low densities throughout the upper basin, with the exception of higher densities in Copper Creek. We identified potential restoration opportunities throughout the upper basin. Fish population surveys in the upper Blackfoot River indicated continued declines in westslope cutthroat trout downstream of the Mike Horse Mine. Downstream surveys, between Lincoln and Nevada Creek, show improved numbers of mature brown trout (Salmo trutta) and fluvial westslope cutthroat trout, but very little change downstream of Nevada Creek compared with 1988 levels. In 1999, restoration efforts continued on 16 streams in the mid-tolower portion of the Blackfoot Watershed. Project monitoring continued on 12 streams where restoration projects have been implemented. Several recent project reaches showed increased fish numbers. Riparian health inventories completed on the Blackfoot River documented overall healthy riparian conditions with the exception of the Blackfoot River corridor in the area of Nevada Creek. Whirling disease investigations showed increased infections at the lower elevations of Blackfoot River watershed.
\end{abstract}


Digitized by the Internet Archive in 2017 with funding from Montana State Library 


\section{Table of Contents}

EXECUTIVE SUMMARY........................................................

Bull Trout Restoration..................................................

Westslope Cutthroat Trout Restoration......................................10

INTRODUCTION........................................................ 13

Study Area....................................................... 14

\section{PROCEDURES}

Working with Private Landowners.................................. 18

Fish Population Investigations............................................ 19

Bull Trout Redd Surveys................................................... 19

Whirling Disease Investigations..................................... 20

Westslope Cutthroat Trout Genetic Investigations......................... 21

Stream Temperatures................................................ 21

Blackfoot River Riparian Health Inventories............................ 21

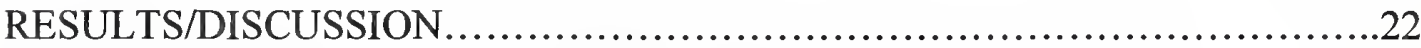

PART I: Blackfoot River Environment: Headwaters to the North Fork

Reach 1: Headwaters to Lincoln, MT................................... 22

Reach 2: Lincoln, MT. to Nevada Creek.................................. 23

Reach 3: Nevada Creek to the North Fork.................................24

Blackfoot River Trout Populations

Reach 1: Headwaters to Lincoln, MT.................................... 24

Reach 2: Lincoln, MT. to Nevada Creek....................................25

Reach 3: Nevada Creek to the North Fork.................................26

PART II: Fisheries Inventories in Tributaries to the Upper Blackfoot River

Alice Creek..........................................................28

Arrastra Creek........................................................29

Bartlett Creek......................................................29

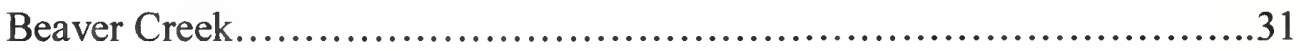

Copper Creek .......................................................... 32

Hogum Creek ....................................................... 32

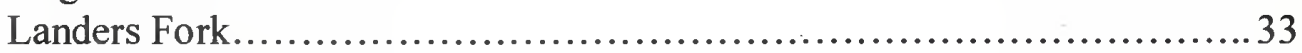

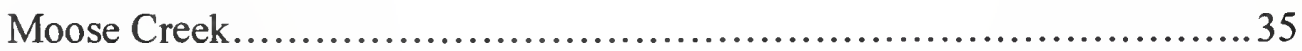

Poorman Creek............................................................. 35

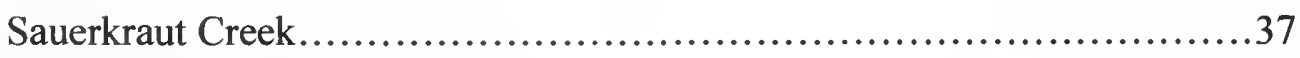

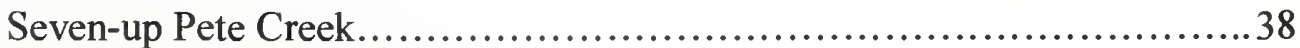

Willow Creek (below Lincoln)............................................39

Willow Creek (above Lincoln)...........................................40 


\section{Table of Contents (cont.)}

PART III: Fish Population and Habitat Assessments for Restoration Streams

Bear Creek.................................................................41

Blanchard Creek.....................................................42

Cottonwood Creek.................................................... 43

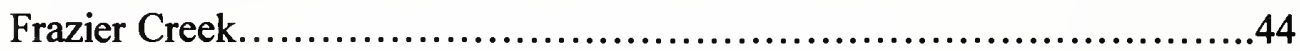

Gold Creek............................................................ 45

Kleinschmidt Creek.................................................46

McCabe Creek.........................................................

Monture Creek.........................................................49

Pearson Creek........................................................50

Rock Creek.............................................................50

Spring Creek...........................................................

PART IV: Additional Aquatic Investigations

Whirling Disease Investigations..................................... 51

Temperature Studies................................................. 53

Blackfoot River Temperatures for August 1999.....................54

Tributary Temperatures for August 1999........................55

Westslope Cutthroat Trout Genetics......................................56

Riparian Health Inventories.........................................57

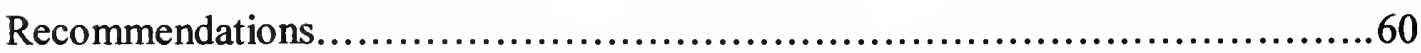

Acknowledgements........................................................61

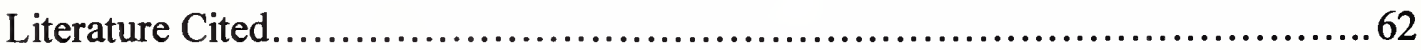

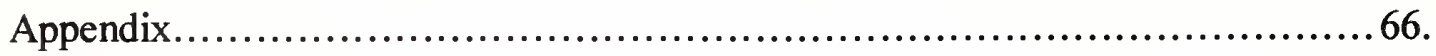




\section{Executive Summary}

In 1999, we expanded fisheries fieldwork from restoration efforts and project monitoring in the lower basin to fish population data collections on 13 tributaries of the Blackfoot River upstream of Nevada Creek. Potential fisheries restoration opportunities were identified on 11 of the 13 tributaries. The upper river effort also included fish population monitoring at five long-term Blackfoot River survey sections last sampled in 1988.

Tributary surveys upstream of Nevada Creek found the distribution of westslope cutthroat trout (Onchorynchus clarki lewisi) throughout the upper Blackfoot River drainage. However several streams supported low densities, particularly in lower stream reaches. Westslope cutthroat trout genetic testing confirmed that the upper Blackfoot Basin is a region of high westslope cutthroat trout purity. Ten of 13 upper Blackfoot River tributaries found no westslope cutthroat trout introgression with other species. However, mild westslope cutthroat trout/rainbow trout (O. mykis) introgression was found at four low-elevation sites within the region, including three tributaries and one section of the upper Blackfoot River. All hybrid samples recorded $<2 \%$ introgression. In 1999 , pure rainbow trout were absent from all upper basin samples although hatchery rainbow trout were stocked in the area of introgression through the mid- 1970s.

Generally, bull trout (Salvelinus confluentus) are at very low densities throughout the upper tributary system with the exception of Copper Creek. Although densities in Copper Creek are higher, they have remained static since the late 1980s. Brook trout ( $S$. fontinalis) distribution extends throughout the upper Blackfoot drainage, with the exception of the Blackfoot River downstream of the Landers Fork and a few tributaries including the Landers Fork and its primary tributary Copper Creek. Brown trout (Salmo trutta) inhabit the lower reaches of several tributaries but were rare in tributaries upstream of Lincoln.

Three of the five long-term Blackfoot River fish population survey sections, located upstream of Lincoln, were resampled in 1988 and 1999. These sites were established in the early 1970s. In 1999, age 1 and older westslope cutthroat trout were absent from the upper-most river survey (Pop's Place Section). The decline of westslope cutthroat trout at this site began in the 1970s and coincides with the release of contaminated mining waste into the upper Blackfoot River. Brook trout densities remained stable in this section between 1988 and 1999 but were lower than densities in the 1970s.

Four miles down stream, in the Flesher Pass Road section, westslope cutthroat trout numbers showed no change between 1988 and 1999, but remain at levels below those recorded in the 1970s. In 1999, brook trout densities returned to the higher levels recorded in the 1970s.

At the Hogum Bridge section, the composition of the sample indicates lower brook trout and higher brown trout numbers than were recorded in the 1970s and 1980s. In 1999, this survey site recorded the only bull trout found in the upper Blackfoot River samples.

The Canyon section, located between Lincoln and Nevada Creek, supported improved numbers of sub adult and adult brown trout and fluvial westslope cutthroat trout. In 1999, the Raymond Bridge section, located between Nevada Creek and the 
North Fork, recorded low numbers comparable to 1988 levels, although numbers of westslope cutthroat trout appear to have improved. Improved westslope cutthroat numbers, combined with signs of angler capture, demonstrate that westslope cutthroat trout in the upper river between Lincoln and the North Fork have responded to catch-andrelease regulations initiated in 1990. However, numbers of sampled westslope cutthroat trout in this reach were considerably less than the lower Blackfoot River downstream of the North Fork where more extensive restoration efforts have occurred. We found very low bull trout densities in upper Blackfoot River samples and recorded no bull trout in the sample section between Nevada Creek and the North Fork.

In 1999, we completed additional fisheries related investigations including restoration project monitoring, riparian health inventories, a basin-wide temperature study, whirling disease studies and angler creel surveys. We continued restoration on 16 streams and fish population monitoring on 12 project tributaries to the lower Blackfoot River downstream of Nevada Creek. These efforts included restoration in three bull trout recovery areas; Cottonwood Creek, Monture Creek and North Fork watersheds. In 1999, bull trout redd counts continued to upward trend in both Monture Creek and the North Fork while the Copper Creek long-term trend is stable. Spring Creek (trib. to Cottonwood Creek) was a bull trout rearing stream in 1989, but supported no bull trout in 1999. Project monitoring for restoration streams documented increased fish numbers in Bear Creek, Gold Creek, Monture Creek and Kleinschmidt Creek. We also established fish population monitoring sections on sections of new project streams including Rock Creek, McCabe Creek, Monture Creek and Pearson Creek

An assessment of the riparian health and plant communities was completed for 55 miles of the Blackfoot River, including 46 river miles between the Landers Fork and Cedar Meadows Fishing Access Site (FAS), and a nine mile section between Corrick River Bend and Gold Creek. The assessment found overall healthy conditions with the exception of the Blackfoot River corridor near the Nevada Creek confluence.

During the summer of 1999, a basin-wide stream temperature study was completed in the Blackfoot Watershed. This study encompassed nine Blackfoot River sampling locations including five long-term monitoring stations, plus 32 sampling sites on 29 tributaries. August temperatures for the Blackfoot River increased in the downstream direction with mean temperature 10 degrees F higher at Milltown Dam than near Lincoln. Maximum river temperatures for August ranged from $>62$ degrees at Lincoln to a high of $>70$ degrees at Raymond Bridge. Tributaries recorded a wide range of thermal properties, reflecting favorable as well as unfavorable conditions for salmonids, depending on the specific tributary.

Whirling disease samples from the lower Blackfoot River were positive for the first time in 1998. The 1999 whirling disease studies show continued spread of the disease and rapidly increasing infection levels at several locations. The known distribution of the disease now extends from Kleinschmidt Creek, located in the North Fork Blackfoot River drainage, down river to the mouth of the Blackfoot River, and includes the lower reaches of at least three other tributaries. Tributaries with increasing infections include but are not limited to Kleinschmidt Creek (grade 3.5), Warren Creek (grade 2.1), Cottonwood Creek (grade 4.7) and and Chamberlain Creek (grade 2.7) Spring Creek near Lincoln and Shanley Creek has also tested positive in 1997 with a lowgrade infection. In 1998, two upper mainstem Blackfoot River samples upstream of the 
North Fork Blackfoot River and the North Fork Blackfoot River upstream of Kleinschmidt Creek tested negative for whirling disease. The Kleinschmidt Creek restoration effort will test the hypothesis that whirling disease can be reduced in a degraded spring creek by restoring stream health and reducing water temperatures.

\section{Bull Trout and Westslope Cutthroat Trout Restoration}

Three previous Blackfoot River reports detail bull trout and westslope cutthroat trout status, life history and restoration information for the Blackfoot River drainage (Peters 1990, Pierce, Peters and Swanberg 1997, and Pierce and Schmetterling 1999). The following section summarizes our general findings from a restoration perspective, synthesizes new information, and is presented to help guide future bull trout and westslope cutthroat trout recovery efforts.

\section{Bull Trout Restoration}

On June 5th 1998, the Secretary of Interior arrived on the banks of the Blackfoot River to announce the listing of bull trout in the Columbia River drainage as "Threatened" under the Endangered Species Act (ESA). During his announcement, Bruce Babbitt mentioned the Blackfoot initiative to be the best example of bull trout restoration within the range of the fish; he urged the restoration team to continue the existing effort. At this time, Blackfoot River bull trout restoration plans are being developed by the Montana Fish, Wildlife and Parks and U. S. Fish and Wildlife Service. The primary goals of the bull trout plan are to restore metapopulations, conserve genetic diversity and restore and maintain connectivity within and between all restoration and conservation areas.

The Blackfoot River currently supports one of the better populations of fluvial bull trout within the range of the species (Peters 1985). Nevertheless, fisheries investigations in the mid-to late 1980s indicated declining populations. Excluding the Clearwater drainage, fluvial bull trout currently inhabit 16 Blackfoot River tributary streams which includes three additional tributaries (upper Nevada Creek, Sauerkraut Creek and Kleinschmidt Creek) identified as supporting bull trout in 1999. Currently, fluvial bull trout inhabit approximately 110 miles of the Blackfoot River mainstem and approximately 330 miles of tributaries. Bull trout have not been documented in the Blackfoot River between the North Fork and Nevada Creek. The majority of fluvial bull trout reproduction occurs in Monture Creek, the North Fork Blackfoot River and Copper Creek in localized areas of groundwater upwelling. Several secondary streams including Gold, Belmont, Cottonwood, Arrastra, Poorman and Alice Creeks support additional but limited bull trout spawning.

Throughout the decade of the 1990s, bull trout recovery efforts were undertaken in five of seven "core" area drainages, and several streams historically supporting bull trout (Pierce et al 1997, Pierce and Schmetterling 1999). Major efforts included fish screening on irrigation canals, riparian livestock management changes, removing barriers to movement, habitat restoration, and erosion control efforts, increasing stream flows, protection of spawning areas and enrolling landowners in perpetual conservation easement programs.

In 1999, three core area watersheds (Cottonwood Creek, Monture Creek and North Fork of the Blackfoot River) received additional special land and water 
management activities directed toward bull trout recovery. Both Monture Creek and the North Fork continue to respond with increased bull trout densities (Figure 1). Bull trout status remains precarious in Cottonwood Creek. Bull trout reproduction and rearing in Cottonwood Creek occurs in headwater areas upstream of stream mile 12.0 upstream of the known distribution of whirling disease (Smith 1998). In this area of the drainage, habitat problems affecting bull trout include degraded riparian areas, habitat simplification and habitat fragmentation including culvert barriers in the North Fork of Cottonwood Creek combined with the recent loss of bull trout rearing areas in Spring Creek.

From 1989 to 1999 , redd counts increased from 10 to 65 in the index reach of Monture Creek and from 7 to 87 in the North Fork Black foot River (Figure 1). While redd counts increased in the two primary lower spawning streams, redd counts in Copper Creek, the primary spawning stream in the upper river bull

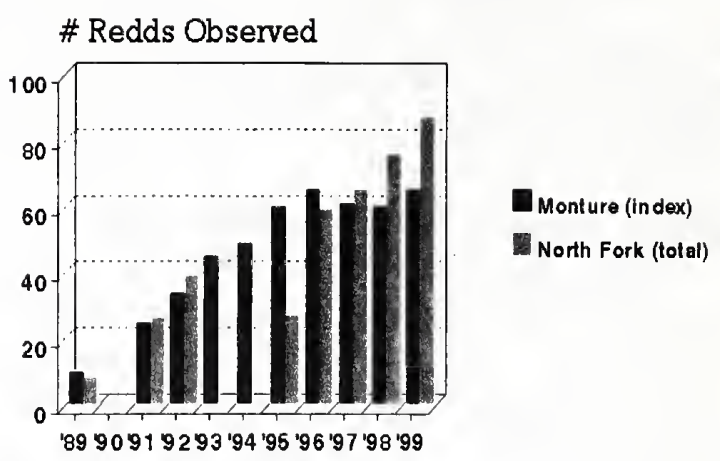
$1989-1999$

Figure 1. Bull trout redd counts for Monture Creek and the North Fork, 1989-1999.

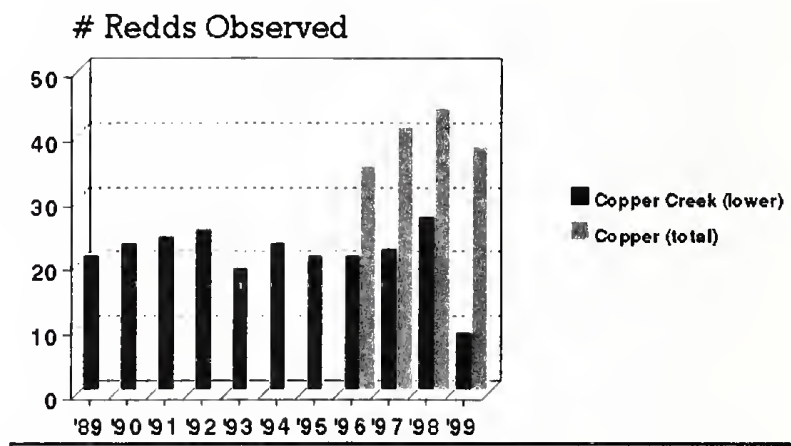

Figure 2. Bull trout redd counts for Copper Creek, 1989-1999. trout population remained static through this period (Figure 2). As of 1998, juvenile bull trout densities were increasing in both Monture Creek and the North Fork. Juvenile bull trout are utilizing several restored smaller tributaries for rearing including Chamberlain, East Twin, Rock, Kleinschmidt and Spring Creeks (Pierce et al. 1997, Pierce and Schmetterling 1999). Temperature studies suggest several additional streams, particularly tributaries to the lower Blackfoot River, as having cool enough summer temperatures to support bull trout use including juvenile rearing and thermal refugia (Appendix $\mathrm{H}$ ). Bull trout densities in the lower river system (Black foot River mouth up stream into the North Fork) were stable to increasing in the 1990s. In 1998, bull trout (fish >6.0") densities increased in the upstream direction from 2.4 to 3.5 to 3.8 fish/1,000' at Johnsrud, Scotty Brown Bridge and Harry Morgan Section of the North Fork, respectively. In comparison, bull trout surveys upstream of the North Fork indicate much lower densities (Figure 3). Although not directly comparable, the differences in sampled numbers between the upper and lower Black foot River are so large that the disparity between the two river sections is obvious. For 5 mainstem Black foot River fish population samples upstream of the North Fork, bull trout estimates were not obtained in 1999 as only three individuals were 
captured in 19,624' of sampled river.

The 1999 upper Blackfoot Basin fisheries inventories found bull trout present in five of thirteen tributaries. Bull trout were present in Sauerkraut, Poorman, Landers Fork, Arrastra and Copper Creeks. All bull trout samples indicated very low abundances with the exception of Copper Creek (Appendix D). Combining all 1999 sample locations on Copper Creek, the catch-per-unit-effort (CPUE) for juvenile bull trout was recorded at 1.4 fish/100', down from the $1989 \mathrm{CPUE}$ of 1.9. The 1999 Copper Creek CPUE was considerably lower than both the 1998 Monture Creek (CPUE of 5.6) and North Fork Blackfoot River (CPUE of 5.6) juvenile densities. In 1999, low numbers of juvenile bull trout were found in the Landers Fork below Silver King Falls in survey sections that supported no bull trout in 1989.

Telemetry studies indicated

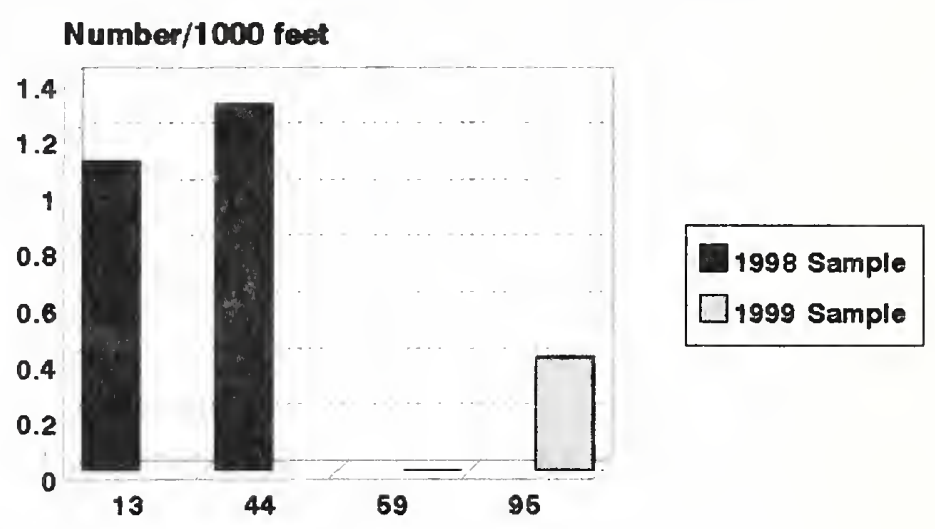

River Mile Midpolnt

Figure 3. Total electrofishing catch for bull trout $>6.0$ inches in four sections of the Blackfoot

that adult bull trout from the lower portion of the Blackfoot River drainage did not migrate to the upper portion of the drainage. This suggests a partial separation of the Blackfoot River population into an upper and lower component (Swanberg 1996, Swanberg and Burns 1997).

Swanberg and Burns (1997) reported that the upper river bull trout component completes its life history in a smaller section of river than the lower river population. In 1996, four of five radio-tagged adult bull trout that spawned in Copper Creek spent the winter in either the lower Landers Fork or in the Black foot River near the Landers Fork confluence. During the fall 1996, one radio-tagged bull trout (post-spawn adult) was trapped and froze in a riffle of the Landers Fork that went intermittent during the outmigration period. In November 1999, the Blackfoot River became intermittent three miles downstream of the Landers Fork. These intermittent reaches further limit adult outmigrant bull trout to restricted areas of winter habitat (Swanberg and Burns 1997). The quality of winter habitat has not been well quantified. Bull trout trapped in intermittent reaches or restricted to marginal winter habitat reportedly result in high morality rates (L. Burns, USFS, personal communication).

In 1996, BioAnalysts Inc. completed an evaluation of fish populations and stream conditions in the upper Blackfoot River and portions of tributary system in the area of the McDonald Mine Project. In their study, bull trout were most common in Copper Creek but were present throughout much of the upper drainage in lower densities. Bull trout often inhabited scour pools, turbulent fast-water habitats and areas with instream woody debris (Hillman and Chapman 1996). This study also characterized much of the Blackfoot River channel upstream of Lincoln as unstable, aggraded and having habitat limitations including highly variable amounts of instream wood. In the Landers Fork below Silver King Falls, habitat complexity was low with the exception of the confluence 
area (Hillman and Chapman 1996). Past channel alteration including the physical removal of instream stream large woody debris contributes to channel instability and habitat simplification in sections of both the Landers Fork and Blackfoot River (FWP unpublished data).

The riparian area of the Blackfoot River between the Landers Fork and Lincoln was rated as healthy in 1999 (Marler and Schmetterling 1999). However, several sections of the channel have also been altered by flood control, stream crossings and instream wood removal. The influences of these past human activities on winter bull trout habitat is poorly understood at this time. In addition, two irrigation diversions currently draw water from the mainstem Blackfoot River in the reach between Lincoln and the Landers Fork. The impacts of these and other possible human activities affecting bull trout need to be further evaluated so that recovery options can be explored. To date, very little actual bull trout restoration has been undertaken in the upper Blackfoot River drainage upstream of the North Fork confluence.

Unintentional illegal harvest and angler non-compliance with fishing regulations has raised concern for bull trout. The 1999 Blackfoot River Creel survey reported bull trout comprised $2.4 \%$ of the total catch, excluding whitefish. Although the actual bull trout catch was low, the proportion of bull trout harvested $(8.2 \%)$ exceeded that for rainbow trout $(7.4 \%)$, brown trout $(7.5 \%)$ and cutthroat trout (1.1\%) (Bohneman and Schmetterling 2000), despite fishing regulations which prohibit the harvest of bull trout. Unintentional illegal harvest of bull trout stems in part from the inability anglers to identify bull trout and other species such as brook trout. A recent study in west-central Montana found that overall only $44 \%$ of anglers surveyed correctly identified bull trout while 49\% correctly identified brook trout (Schmetterling and Long 1999). The 1999 Blackfoot River creel survey also reported that brook trout comprised $3.7 \%$ of the Blackfoot River catch, of which 31\% were kept (Bohneman and Schmetterling 2000). The percent of brook trout caught, although low, conflicts with fish population data that consistently finds brook trout rare to absent over the length of the Blackfoot River between Milltown Dam and Lincoln. The high percentage of "brook trout" kept combined with the inability of anglers to correctly identify brook trout may indicate a degree of additional unintentional bull trout harvest.

\section{Westslope Cutthroat Restoration}

Within the last 100 years, westslope cutthroat trout have declined throughout much of their historic range, particularly east of the Continental Divide. Liknes (1984) and Shepard et al. (1997) estimated that westslope cutthroat trout currently inhabit only about $20 \%$ of their former range in Montana, and genetically pure populations are found in less than $10 \%$ of their current range (Liknes and Graham 1988, Shepard et al. 1997). Reasons for the decline of westslope cutthroat trout include habitat loss and degradation, genetic introgression with introduced rainbow trout and Yellowstone cutthroat trout overharvest as well as competition with exotic species such as brook trout and brown trout (Liknes 1983, Alllendorf and Leary 1988, Liknes and Graham 1988, McIntyre and Rieman 1995). This decline lead to their status as a "species of special concern" in Montana and, currently, the FWS is reviewing a petition to list this fish as Threatened under the ESA. The listing decision is due out in April 2000.

Throughout the 1990s, westslope cutthroat trout recovery efforts were undertaken 
on several from and included the adoption of catch-and-release regulations in 1990, increased enforcement, and restoration. Westslope cutthroat trout are currently increasing in abundance in the lower elevations including several tributaries and the mainstem Blackfoot River. Between 1989 and 1998, fluvial westslope cutthroat trout (fish $>6.0$ ") in the lower Blackfoot River have increased from 1.3 to 11.8 fish/1,000' in the Johnsrud Section (rm 12-16) and from 2.9 to 21.9 fish $/ 1,000^{\prime}$ in the Scotty Brown Bridge section (rm 42-46) (Pierce and Schmetterling 1999). In 1999, westslope cutthroat trout comprised $58 \%$ of the Blackfoot River angler catch (excluding mountain whitefish), up from 19\% in 1994 (Peters and Workman 1996, Bohneman and Schmetterling 2000).

Populations of westslope cutthroat trout have been found in all major headwater streams, including 54 of 60 sampled Blackfoot River tributaries. The six tributaries that recorded no westslope cutthroat trout were degraded lower elevation streams and/or brown trout dominated spring creeks. Spatial segregation from introduced rainbow and brown trout occurs at lower elevations usually within 0 to 5 miles of the mouths of all major streams depending on the specific stream system (Peters 1990, Pierce et al 1997). This segregation appears to be environmentally controlled, rather than related to physical barrier, since migration barriers do not occur within the species transition zones for these tributaries. Rather, this segregation appears to be controlled by longitudinal differences in the stream environment that are both natural and human caused. Environmental factors such as stream temperature, stream size, gradient and naturally intermittent stream reaches which separate basin-fed from groundwater-fed stream combined with habitat degradation, species selective fishing pressure, and fish loses to irrigation ditches, seem to have played a significant role in creating this distribution (Peters 1990).

Westslope cutthroat trout rely on high quality habitat in tributaries for spawning, rearing and over-wintering. Free access from large river systems to headwater spawning streams is also necessary for the fluvial life-history form. A 1998 telemetry study of Blackfoot River fluvial westslope cutthroat trout movement recorded a mean spawning migration of 19 stream miles. One radio-tagged westslope cutthroat trout moved 45 miles from the lower river to a spawning area in the Monture Creek drainage (Schmetterling 2000).

Juvenile westslope cutthroat trout generally migrate downstream to the large river system at age three (range 2-4). This movement pattern suggests an adaptation to the river environment related to juvenile survival, and possibly severe anchor ice formation in the Blackfoot River, which periodically results in high YOY mortality for non-native species (Peters 1990, Pierce et al. 1997).

Due to their dependence on tributaries, significant tributary restoration activity has been directed toward the recovery of both resident and fluvial westslope cutthroat trout. In conjunction with fluvial bull trout recovery efforts, the focus of fluvial westslope cutthroat trout restoration is reestablishing the fluvial life-history form by: 1) reducing or eliminating "controllable" sources of mortality; 2) maintaining or restoring existing spawning and rearing habitats; 3) restoring damaged habitats; and 4) reestablishing connectivity for the Blackfoot River to spawning areas.

Restoration projects targeting these features have been completed throughout the lower to middle region of the Blackfoot drainage. Increased densities have been noted in sections of the North Fork Blackfoot River, Monture, Chamberlain, Gold, Dunham and Cottonwood Creeks (Pierce and Schmetterling, 1999). Recent restoration activities in the 
North Fork, Monture Creek, Bear Creek, and McCabe Creek drainages should further benefit westslope cutthroat trout.

The 1999 tributary surveys documented the widespread distribution of westslope cutthroat trout throughout the upper Blackfoot River drainage, although numbers were low in several locations. Westslope cutthroat trout genetic samples showed the upper Blackfoot Basin to be a region with a high level of genetic purity with no introgression recorded in 10 of 13 streams. However very low level introgression with rainbow trout is present at four areas previously stocked with rainbow trout into the early 1970s. No pure rainbow trout have been recorded in the upper drainage since the adoption of the wild trout management philosophy. Tributaries that appear to have excellent opportunities for westslope cutthroat trout restoration include Poorman, Sauerkraut, Beaver and lower Willow Creeks.

The upper river samples documented the loss of the westslope cutthroat trout population in the Pop's Place Section, with no age 1 and older westslope cutthroat trout and only one YOY found in the section. This decline began in the 1970s and coincides with the release of contaminated mine effluent, including high levels of lead, copper, zinc and of bio-available cadmium, into the upper river sediments from the Mike Horse mine area (Spence 1975, Peters and Spoon 1989, Moore et al.1991). In the Flesher Pass section, age 1+ westslope cutthroat trout showed no change between 1988 and 1999, but remain below levels recorded in the 1970s.

Catch-and-release regulations initiated in 1990 contribute to fluvial westslope cutthroat trout increases at both the Canyon and Raymond Bridge sampling locations. These upper river reaches have received limited restoration activities. The 1999 surveys for these two locations indicate considerably lower densities compared to the lower Blackfoot River where tributary restoration

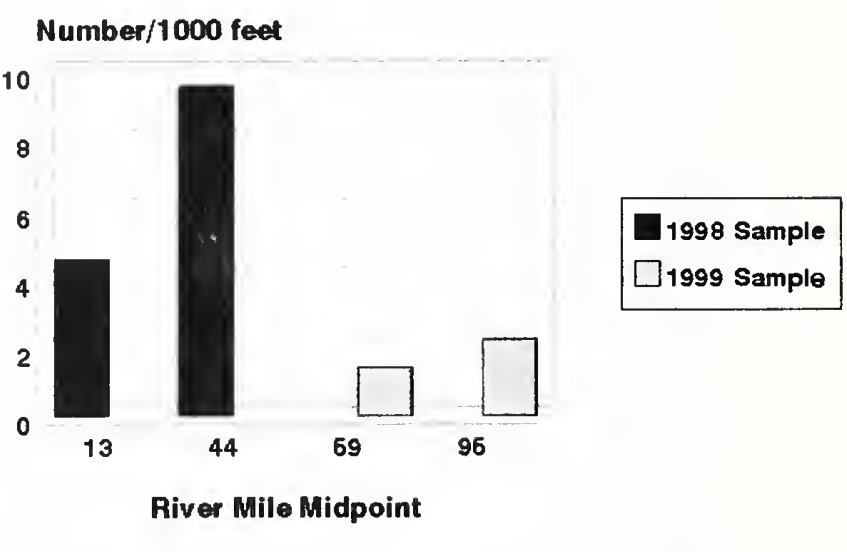

Figure 4. Total electrofishing catch for westslope cutthroat trout (fish>6.0") at four locations of the Blackfoot River. contributes to increased westslope cutthroat trout recruitment to river populations (Figure 4).

The Raymond Bridge section, located between Nevada Creek and the North Fork confluence with the Blackfoot River, supports particularly low numbers of westslope cutthroat trout. Although several small streams enter this reach from the Garnet Mountains, all streams are fisheries impaired. Beginning in 1988, fish population surveys combined with a wide range of related assessments have been completed on this river reach, including all tributaries to this river reach and all adjacent Garnet Mountain tributaries. In general, surveys found populations of westslope cutthroat trout in headwater areas of all Garnet Mountains streams but damaged riparian areas and impaired fish populations at the lower elevations. This region of impaired fisheries extends from the Union Creek watershed east along the foothills of the Garnet Mountains into the Nevada Creek watershed and includes the Blackfoot River corridor between the 
confluence of the North Fork and Nevada Creek. This river corridor and the lower reaches of most tributaries in this region could be better managed for riparian health and fisheries and should also be considered for more focused restoration efforts.

\section{Introduction}

Fish population studies in the late 1980 s and early 1990 s identified that 1 ) mining impacts in the headwaters, 2) over-exploitation of the fishery, and 3) extensive degradation of tributary habitats contributed to declining Blackfoot River fish populations. These studies also documented low densities of native westslope cutthroat (Onchorynchus clarki lewisi) trout at the mid- to low elevations of the Blackfoot Watershed (Peters and Spoon 1989, Peters 1990). Bull trout (Salvelinus confluentus) densities were low basin-wide, with local populations extirpated in several streams. Fisheries investigations found that early life stages of salmonids in the lower Blackfoot River rely on tributaries. Tributary assessments reported extensive problems that spanned multiple land ownerships and resulted in fish population declines at a regional scale (Peters and Spoon 1989, Peters 1990, Pierce et al. 1997, Pierce and Schmetterling 1999).

Low numbers of adult rainbow (O. mykis) and brown trout (Salmo trutta) at the low to mid elevations of the watershed, combined with high winter mortality of youngof-the-year (YOY) and poor tributary habitats resulted in weak recruitment to river populations for these species (Peters and Spoon 1989, Peters 1990, Pierce et al. 1997). Reliance of native fish on upper tributaries at early life stages indicates adaptation to the severe environment of the Blackfoot River. However, due to poor tributary conditions, long migrations and more extensive use of the tributaries at early life stages, fluvial native fish are also more subject to human impacts in the tributary system than introduced fish species.

Throughout the 1990s, the Blackfoot River watershed has been the site of cooperative private and public lands fisheries restoration initiative. During this effort, 34 tributaries to the Blackfoot River received special riparian and upland restoration activities that provide for the needs of riparian-dependant species including wild trout populations. Priority for restoration was given to streams supporting populations of native westslope cutthroat trout and bull trout, especially tributaries of the lower to middle Blackfoot River. Restoration tools include reconstructing stream channels and restoring habitat features to damaged streams, developing low impact grazing systems and removing streamside feedlots, planting native riparian vegetation, improving stream flows, restoring fish migration corridors and enrolling landowners in perpetual conservation easement programs. Cooperators included private landowners, non-profit groups, and state and federal agencies.

Restoration efforts have contributed to broad improvements in native fish populations at the low to mid elevations of the watershed. Westslope cutthroat trout densities have increased approximately $900 \%$ in the lower to middle reaches of the Blackfoot River downstream of the North Fork confluence. Several tributaries are supporting increased westslope cutthroat trout densities as well. Bull trout densities, although low, are stable to increasing in the lower river system including both Monture Creek and the North Fork Blackfoot River. 
Although fish populations are improving in the lower watershed, addressing major issues such as mining impacts and habitat problems is far from complete. Most of the Blackfoot Watershed has received limited restoration effort; these areas include the upper Blackfoot River drainage upstream of Nevada Creek, the Garnet Mountains Clearwater River drainage and the upper Nevada Creek drainage. In addition, several issues beyond the original scope of identified problems have emerged in the last several years. These additional challenges to the conservation of native fishes include: 1) the introduction of exotic fishes including northern pike (Exos lucius) to the Blackfoot River drainage; 2) the remediation of Milltown dam impacts; 3 ) the introduction and rapid escalation of whirling disease; and 4) significant upward trends in recreational river use, combined with the inability of anglers to identify bull trout and unintentional illegal harvest (Schmetterling and Long 1999, Bohneman and Schmetterling 2000).

In 1999, we continued to correct habitat problems in the lower watershed. We also expanded fisheries investigations into the headwaters of the upper Blackfoot Basin upstream of the Nevada Creek confluence as an initial effort to identify problems and expand the restoration program. The effort included not only the collection of baseline fish population and qualitative habitat information for 13 tributaries, but also repeat monitoring of fish populations at 5 long-term Blackfoot River survey locations last sampled in 1988. Concurrent with the upper basin studies, we completed several additional fisheries-related investigations in 1999 including riparian health evaluations, restoration project monitoring, and basin-wide temperature and whirling disease studies.

Primary objectives of the report are to: 1) document fish population changes in the upper Blackfoot River; 2) report fish population survey results, including westslope cutthroat trout genetic test results for 13 tributaries to the upper Blackfoot River; 3) identify specific stream and river reaches with potential for future fisheries restoration efforts; 4) report changes in the species composition and densities of fish and changes in their habitats resulting from restoration efforts; 5) present results of other aquatic studies which relate to the health and recovery of the Blackfoot River fisheries; and 6) help guide future restoration activities.

\section{Study Area}

The Blackfoot River, located in west-central Montana (Figure 5), flows 132 miles in a westerly direction from its headwaters near the Continental Divide to its confluence with the Clark Fork River at Bonner Montana. Mean annual discharge is 1,597 cubicfeet-per-second (cfs). This river system drains 2,400 square miles through a 3,700-mile stream network of which 1,900 miles are perennial streams capable of supporting fish populations. The Blackfoot River is a free flowing river to its confluence with the Clark Fork River where Milltown dam, a run-of-the-river hydroelectric facility, has blocked upstream fish passage since 1907.

The Blackfoot River is becoming an extremely popular angling destination in western Montana. In 1997, the Blackfoot River accommodated 35,345 anglers, up 76\% from 20,043 anglers in 1991 (Figure 6). Improvement of the fish populations resulting from efforts of private citizens, landowners, conservation groups and resource agencies has added to the rivers overall health and popularity among anglers and outfitters.

Land ownership in the Blackfoot watershed is $44 \%$ National Forest, $5 \%$ Bureau of 
Land Management, 7\% State of Montana, 20\% Plum Creek Timber Company and 24\% other private ownership. In general, public lands and significant portions of Plum Creek Timber Company properties comprise the forested mountainous areas while private lands are located in the foothills and lower valley area.

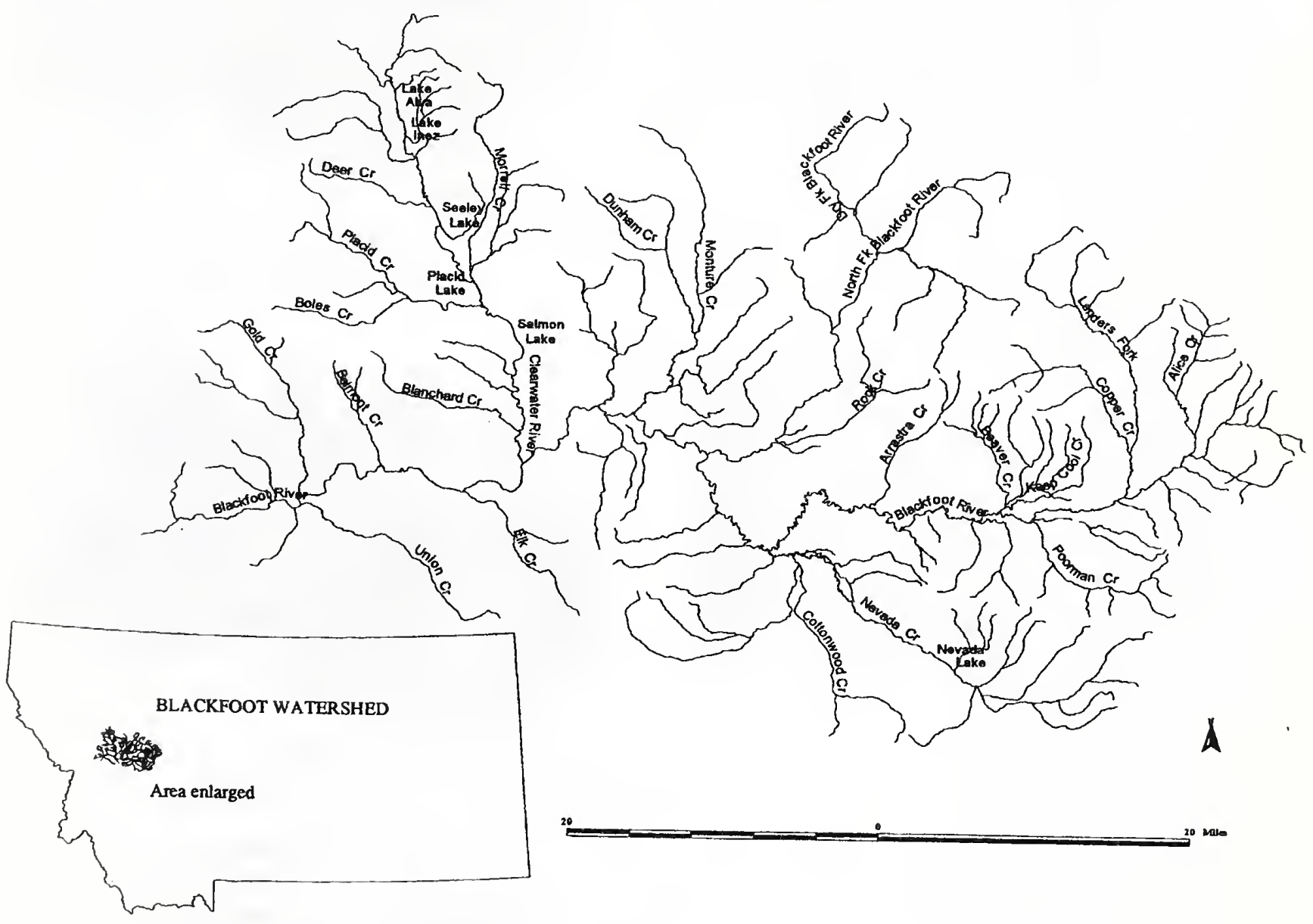

Figure 5. Study area. The Blackfoot River watershed.

The physical geography of the watershed ranges from high elevation glaciated alpine meadows to prairie pothole topography on the valley floor. The main east-west axis of the Blackfoot Valley separates steep, high elevation glacial mountains in the north from lower, non-glacial rounded mountains to the south. Except for a canyon reach between the Lincoln and Ovando valleys, four mountain blocks surround an essentially broad upper valley that constricts to form a narrow lower canyon downstream of the Ovando valley.

The geology of the basin generally consists of upthrust and glaciated Precambrian Belt Series rock, with localized igneous intrusions and mineralization occurring in the 
Garnet Mountains located south of the Blackfoot River, and along the eastern margin of the basin. Glacial landforms, moraine and outwash, glacial lake sediments and erratic boulders cover the entire floor of the Blackfoot River valley and exert a controlling influence on the habitat features of the Blackfoot River. Glacio-fluvial landforms, including blankets of gravelly outwash, cover the bottom of several stream valleys north of the Blackfoot Rivers, creating sections of seasonally intermittent channel on most major tributaries.

The Blackfoot River supports a diversity of wild trout populations (Figure 7). Distribution patterns of most salmonids generally conform to the physical geography of the landscape. Species

richness increases

longitudinally in the downstream direction.

Species assemblages and densities of fish can also vary greatly at the lower elevations of the watershed.

Westslope

cutthroat trout are

distributed throughout the watershed and is the most abundant species in the upper reaches of the tributary system. Bull trout distribution extends from the mainstem Blackfoot River to extreme headwaters of

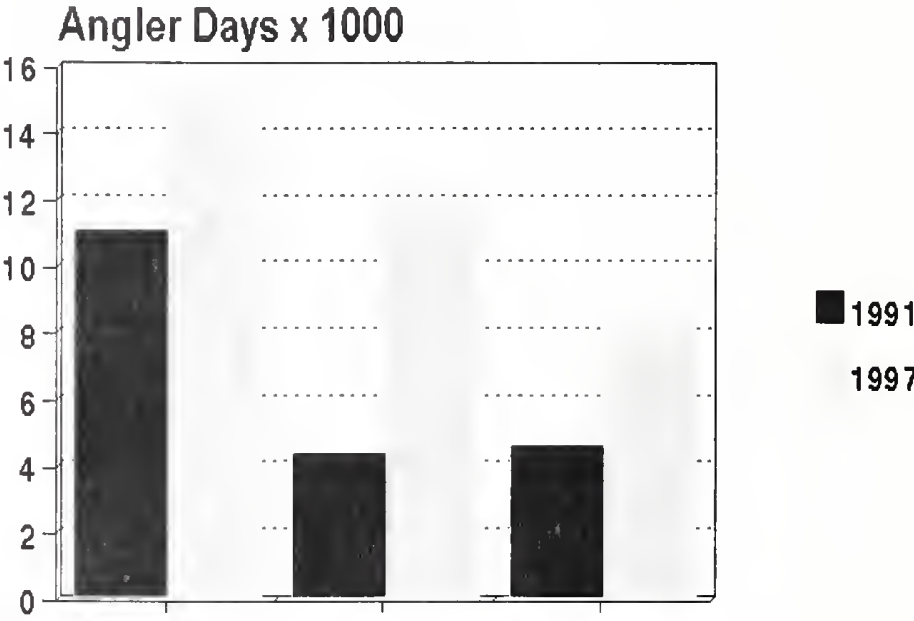
larger tributaries north of the Blackfoot River; however, juvenile bull trout will rear in several smaller non-spawning tributaries, some of which are located in the Garnet Mountains (Pierce and Schmetterling 1999). Rainbow trout distribution is limited to the lower Blackfoot River and lower reaches of the lower river tributaries; this species occupies approximately $8-10 \%$ of the perennial streams in the Blackfoot Watershed. Brown trout inhabit approximately $15 \%$ of the perennial stream system with a distribution that extends from the Landers Fork down the length of the Blackfoot River and into the lower foothills of the tributary system. Brook trout are widely distributed in the watershed although rarely found in the mainstem Blackfoot River below Lincoln. 
Figure 7. Trout distribution for the Blackfoot River drainage.
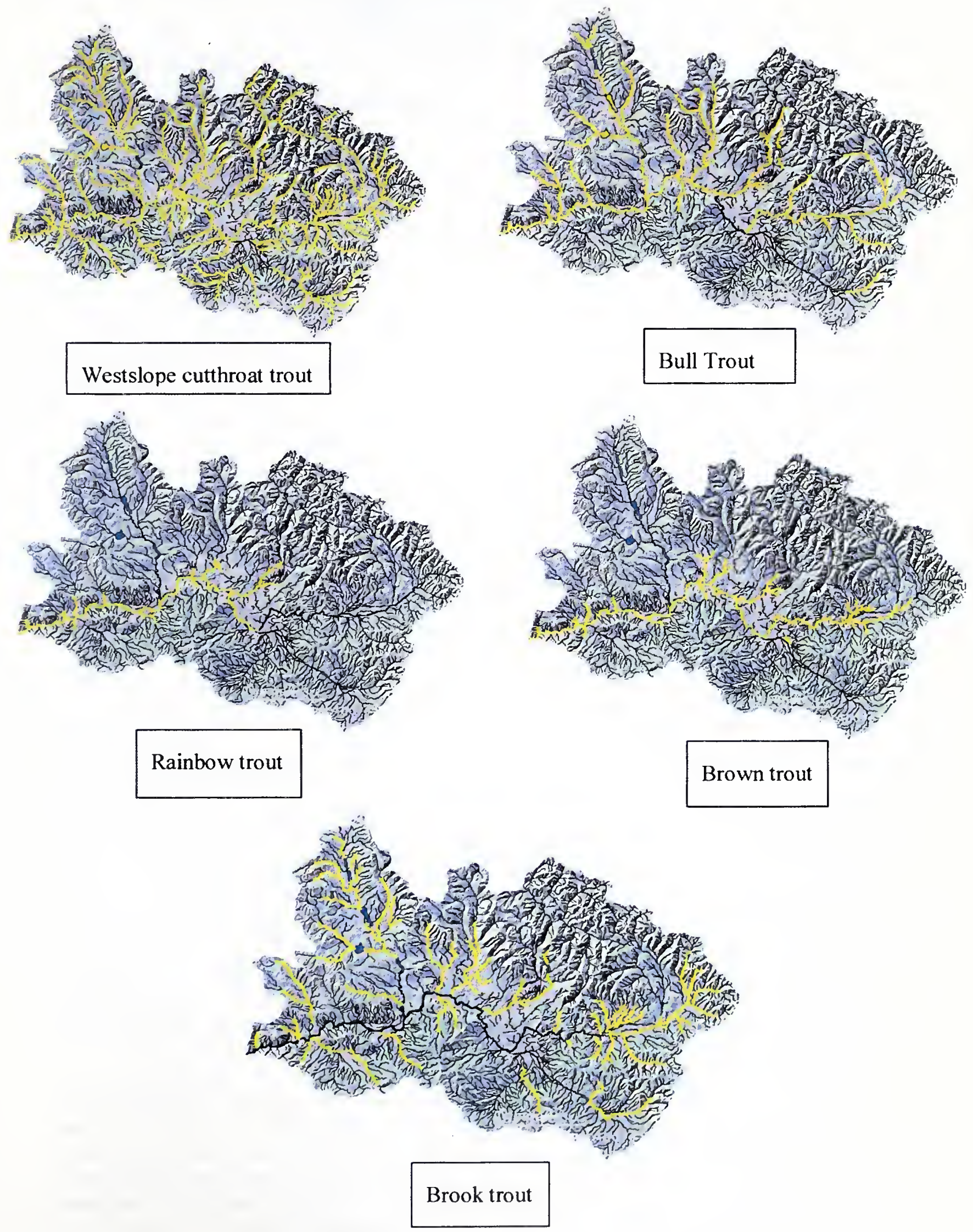



\section{Procedures}

\section{Working with Private Landowners}

Restoration efforts in the Blackfoot River watershed focus on restoring degraded tributaries by improving riparian areas and fish habitat. Typically each tributary project involves multiple landowners, multiple professional disciplines, more than one funding source and the involvement of a watershed group. Restoration has focused on addressing obvious fisheries impacts such as migration barriers, stream dewatering, fish losses to irrigation canals and degraded riparian areas. All projects are cooperative efforts between private landowners and the restoration team, and occur throughout the drainage. All projects incorporate landowner objectives, are voluntary, non-regulatory and are administered at the local level by a core group of agency resource specialists in cooperation with local watershed group (non-profit 501(c)(3)), including both the Big Blackfoot Chapter of Trout Unlimited and the Blackfoot Challenge, or local government groups such as the North Powell Conservation District.

Two full-time restoration biologists help coordinate restoration efforts. A lead biologist generally enlists help from interagency personnel including range conservationists, hydrologists, engineers and water rights specialists as necessary. In turn, the watershed groups help prioritize projects, administer budgets, solicit bids and assist with landowner contracts, plus help address local social issues.

Cost sharing of projects is arranged by project personnel and comes from many sources including landowner contributions, private donations, foundation grants, and state and federal agency programs. Project biologists and/or the watershed group undertake grant writing and fund-raising. Environmental assessments and project permitting are usually handled by the biologist on behalf of cooperating landowner.

Project bids for consulting and construction services follow State and Federal procurement policies. These policies included the development of a qualified vendors lists (QVL) derived through a competitive process. A minimal project cost triggers the use of the QVL. The watershed groups solicit bids from the QVL for both consulting and contractor services. Bid-contracts are signed between the watershed group and the selected vendor upon bid acceptance.

Depending on the specific project, landowners are responsible for much of the construction and maintenance of projects. Addressing the source of stream degradation usually requires developing riparian/upland management options sensitive to the requirements of fish and other riparian-dependent species. Written agreements with landowners to maintain projects for a minimum 10-year period are arranged with cooperators on each project. These agreements vary by funding source and may include either agencies, the North Powell Conservation District and/or the Fish and Habitat Committee of the Big Blackfoot Chapter of Trout Unlimited.

Landowner awareness of the habitat requirements of fish and wildlife and their full participation in projects are considered crucial to the long-term success of the restoration initiative. Landowners are encouraged to participate in all project phases from fish population data collection to problem identification and restoration to monitoring of completed projects. Although many restoration projects have been completed in the Blackfoot River watershed, this effort is considered educational at a broad level and is far from complete. 


\section{Fish Population Investigations}

Fish population densities were calculated using single-pass, mark-recapture, or multiple pass-depletion methods. We used mark-recapture in the Blackfoot River and Monture Creek and depletion estimates in small streams. Population densities using the mark-recapture method were estimated using Chapman's modification of the Petersen formula (Ricker 1975); confidence intervals were calculated using the Seber Formula. For small streams, fish population surveys rely on two general methods. The first is a single pass catch-per-unit effort (CPUE), the second is a population density estimate generated from a two-pass depletion survey. We used simple linear regression to analyze the degree of association between the two methods. The result indicated a close relationship between the two methods, $\mathrm{R}$-square $=0.902, \mathrm{P}<0.0001$ (Pierce et al. 1997). Small stream size and highly efficient electrofishing conditions in our study streams contributed to this outcome. Although CPUE is a good index to population density, CPUE does not include a confidence interval like the actual population density estimate. For this report CPUE refers to the number of fish collected in a single electrofishing pass and is adjusted per 100' of stream (I.e. CPUE of 8 means 8 fish captured per 100' of sampled stream). Actual population estimates are referred to as density/100'. The $95 \%$ confidence intervals for these estimates are found in Appendix C.

Fish were captured using a boat or backpack mounted electrofishing unit. In small streams, we used a gas-powered backpack mounted DC electrofishing unit (Coffelt Mark 10). The anode (positive electrode) was a hand-held wand equipped with a 1-footdiameter hoop; the cathode (negative electrode), a braided steel wire. On Monture Creek and the Blackfoot River Raymond Bridge and Canyon Sections, we used an aluminum drift boat mounted with a Coffelt Model VVP-15 rectifier and 5,000 watt generator. The hull of the boat was used as a cathode and two fiberglass booms, each with four steel cable droppers, served as anodes. We used direct DC current forms with output less than 1000 watts, which is an established method to significantly reduce spinal injuries in fish associated with electrofishing (Fredenberg 1992). Young-of-the-year (YOY) trout were sampled in the tributaries from August to November. Extra effort was used to sample stream edges and around cover to enable comparisons of densities between sampling sections. Captured fish were anaethesized with methansulfonate (MS-222), weighted (g) and measured (mm) for total length (TL). For this report, we converted all weights and lengths to standard units.

In 1999, we duplicated five long-term electrofishing sections, four of which were originally established in 1975 (Spence 1975) and were last sampled in 1988 (Peters and Spoon 1989); these sections included 1) Below Pop's Place, 2) Flesher Pass Road, 3) Hogum Bridge, and 4) Canyon sections. We also duplicated the Raymond Bridge section; this section was established and last sampled in 1988. Fish population survey sections and field procedures were consistent with those of Peters and Spoon (1989). All five duplicate section lengths were remeasured to account for potential channel changes and errors in identifying previous section boundaries.

\section{Bull Trout Redd Surveys}

Bull Trout redds were surveyed in Copper Creek, Monture Creek and North Fork Blackfoot River. Redd counts were not complete counts and serve as an index of 
spawning adult abundance in selected reaches. Counts were made by walking the stream bank in identified spawning areas in late September. Redd areas were identified by a cleaned, oval shape (pit), and a mound of unconsolidated gravel (tailspill) left by the females digging activities. Only redds where a definite pit and tailspill were discernable were counted.

\section{Whirling Disease Investigations}

Whirling disease surveys including live fish cage studies were undertaken in the Blackfoot Watershed in both 1998 and 1999. The live cage study is a controlled experiment used to detect levels of whirling disease. In both years, detection of whirling disease relied on histological examination of hatchery rainbow trout placed in sentinel cages. The live cages used consisted of an $18 \times 24$ " cylindrical screened container placed into a stream site allowing stream water to flow through the cage. Each cage contained 50 uninfected $35-60 \mathrm{~mm}$ rainbow trout or westslope cutthroat trout supplied by a state fish hatchery. Timing of field exposure was based on anticipated mean daily temperatures in the 50's which correlates with peak triactinomyxon (TAM) production and correspond to peak infection rates in fish. The exposure period for each live cage was standardized at 10 days. At the end of the 10-day exposure period, the trout were removed and taken to Pony, MT, where they were held for an additional 80 days at a constant $50 \mathrm{~F}$ temperature to insure the WD infection would reach its maximum intensity. At the end of the 90 day period all the surviving fish were sacrificed and sent to the Washington State University Animal Disease Diagnostic Laboratory at Pullman, WA. In order to determine the degree of infection, a histological grading system was developed by Dr. Beth MacConnell of the USFWS and Dr. Tom Baldwin of the Washington State University Animal Disease Diagnostic Laboratory. Using samples from a select portion of the fish's cranium, the degree of WD infection is given a score based on the degree of cartilage damage and tissue inflammation. Rankings were assigned a numerical rating from " 0 " which had no detectable infection to " 5 " where there was extensive cartilaginous necrosis and severe inflammation. At this point in time, it is generally felt that when mean infection intensities exceed 2.50 significant adverse impacts on wild salmonid populations are likely to occur (Vincent 2000). The results of this histological rating were presented as percent of fish infection intensity (Appendix I). Because peak infection rates correlate with mean daily stream temperature (F) in the mid- $50 \mathrm{~s}$, every live cage site also had an accompanying thermograph to establish mean daily water temperatures during this exposure period (Appendix I). In July 1998, six cages were placed in tributaries and six in the mainstem Blackfoot River. In August and September 1999, fourteen additional sentinel cages were placed including 6 duplicate mainstem samples and eight tributary samples, three of which were place in the Chamberlain Creek watershed (Chamberlain mainstem, East Fork and West Fork) as a time series study (Appendix I)

\section{Westslope Cutthroat Trout Genetic Investigations}

In 1999, westslope cutthroat trout genetic samples were taken from 13 tributaries to the Upper Blackfoot River upstream of Nevada Creek and two upper Blackfoot River mainstem locations. Samples consisted of fin-clip tissue samples taken from 25 individual fish when possible. Samples collected were immediately preserved in $95 \%$ 
ethyl alcohol and taken to the University of Montana, Salmon and Wild Trout Genetics $\mathrm{Lab}$ for electrophoretic analysis.

The Paired Interspersed Nuclear DNA Element-PCR (PINE-PCR) method was used to determine each fish's genetic characteristics at 21 regions of nuclear DNA. This method produces DNA fragments (hereafter PINE markers) that distinguish westslope cutthroat trout, from rainbow trout and Yellowstone cutthroat trout (O. clarki. bouveri). These species, specific PINE markers, therefore, can be used to determine whether a sample came from a genetically pure population of one of these fishes or one in which hybridization between two or all three of them has occurred. With a sample size of 25 fish, this testing method has a $95 \%$ chance of identifying as little as $1 \%$ introgression ( $R$. Leary, personal communication). A compilation of all westslope cutthroat trout genetic samples collected to date in the upper Blackfoot River drainage upstream of the mouth of Nevada Creek can be found in Appendix J.

\section{Stream Temperature}

In the mid-to-lower reaches of the Blackfoot River and its tributary system, warming during summer period periodically increases to levels considered stressful for salmonids ( $>70$ degrees F). During the summer of 1999, we completed a basin-wide stream temperature study for the Blackfoot Watershed. The study included nine Blackfoot River sampling locations, including five long-term sampling locations, plus 32 sampling sites on 29 tributaries (Figure 36). Of these 29 tributaries, 19 are direct tributaries to the Blackfoot River. For these 19 tributaries, temperature sensors were placed near their confluences with the Blackfoot River.

Objectives of the temperature study were to: 1 ) profile temperatures over the length of the river; 2) identify thermal properties of principle tributaries which enter the river; 3 ) identify thermal regimes favorable and unfavorable for trout throughout the system; 4) monitor stream restoration projects; and 5) establish additional baseline for future study efforts.

In 1999, water temperatures (Fahrenheit) were recorded at 48 to 72 minute intervals using Hobo temperature data loggers. Data for each station is summarized with monthly mean, maximum, minimum and standard deviation in Appendix $\mathrm{H}$.

\section{Blackfoot River Riparian Health Inventories}

In the summer of 1999 , a riparian health inventory was completed on 62.8 miles of the Blackfoot River including reaches between 1) the Landers Fork and Nevada Creek, and 2) between Corrick River Bend and Gold Creek (Marler and Schmetterling 1999).

For this inventory, major plant communities were identified and mapped on highresolution aerial imagery as described by Marler (1998) and the BLM (1994). Special attention was given to location and coverage of noxious weeds, following the guidelines of the Montana Noxious Weed Survey and Mapping System. Mapped locations and metadata were submitted to the Montana Weed Survey database at Montana State University, Bozeman.

A Riparian and Wetland Research Program Riparian Health Form was completed for each ownership unit in the study area. This portion of the inventory measured erosion, channel incision and amount of plant cover in addition to providing a numerical health rating between $0-100$ points. Erosion (sections $>2$ meters) and areas of poor health 
were mapped and classified as either natural or anthropogenic (including livestock impacts).

Layers of erosion, plant community types, and noxious weed locations were mapped over georeferenced GIS base layers of high-resolution aerial multi-spectral ADAR imagery. Plant communities were mapped as polygon feature shapefiles and were linked with the associated database of each unit. Separate layers were included for noxious weeds. These are represented as point features of infestations smaller than 5 acres, and polygon features for infestations larger than 5 acres. Riparian health and erosion was mapped as line features. Only the poorest riparian health sections were mapped, but all the eroded sections ( $>2$ meters) were mapped. The associated database for erosion included length, severity and source (natural or anthropogenic causes).

\section{RESULTS / DISCUSSION}

Fisheries investigations for 1999 are presented in four sections. Part I summarizes the physical features of three river reaches of the Blackfoot River, along with fish population monitoring results at 5 upper Blackfoot River locations. Part II summarizes stream information, habitat observations and new fisheries inventory results for 13 tributaries to the upper Blackfoot River upstream of the Nevada Creek confluence. Part III summarizes recent projects, status of fish

Figure 8. Blackfoot River reaches and fish population survey locations.

populations, their habitats and other related monitoring results for 11 restoration project streams. Part IV presents results and discussion of additional aquatic investigations that relate to the health and recovery of Blackfoot fish populations; these include results from whirling disease investigations, temperature studies, and westslope cutthroat trout genetic testing and riparian health inventories.

\section{Part I: Blackfoot River Environment: Headwaters to the North Fork}

Based on distinct breaks in physical river features and attributes of the fish populations, Peters and Spoon (1989) divided the upper river into three reaches. They are 1) headwaters to Lincoln, MT, 2) Lincoln to Nevada Creek, 3) Nevada Creek to Monture 
Creek. For this report, reach 3 was shortened to include the section from Nevada Creek to the North Fork confluence (Figure 8).

\section{Reach 1 Headwaters to Lincoln, MT.: River mile 132 to 108}

This reach begins in a mineralized section of the overthrust belt on the western slopes of the Continental Divide below Rogers Pass. Beginning in the extreme headwaters, this river reach drains the Heddleston Mining District before entering a series of terminal moraines that form a series of large willow wetlands. Several placer and hard rock mines are located in this area of which the Mike Horse is the largest. The Mike Horse and other mines have a history of releasing acid mine drainage including sulfate and heavy metals into the upper section of this river reach (Spence 1975, Moore et al. 1991, Menges 1997).

The two primary tributaries to this reach are Alice Creek and the Landers Fork. Alice Creek enters the Blackfoot River in the wetland area. The Landers Fork enters below the wetlands and provides significant inflows of cooler water. Below the Landers Fork, the mainstem Blackfoot River occupies a Rosgen (1996) C4-C5 channel type and runs along the southern extent of its valley, immediately adjacent and parallel to the walls of the canyon. As the valley widens above Lincoln the Blackfoot River seasonally loses water to alluvium and becomes intermittent approximately three miles downstream of the Landers Fork. In November 1999, stream discharge declined from $31 \mathrm{cfs}$ immediately below the Landers Fork at river mile 116.0 to $0.5 \mathrm{cfs}$ at river mile 112.6. Stream discharge then increased to $5.2 \mathrm{cfs}$ at river mile 109.6. Stream gradient in this reach averages $24.6 \%$ mile (Peters and Spoon 1989). The riparian area is generally considered healthy with the exception of the area immediately adjacent to Lincoln, MT which has a reduced health rating (Marler and Schmetterling 1999). However, sections of river channel upstream of Lincoln appear unstable, aggraded with habitat limitations and have highly variable amounts of instream wood.

\section{Reach 2: Lincoln, MT. to Nevada Creek: River mile 108 to 68}

Near Lincoln, constriction of the valley forces water to resurface (Coffin and Wilke 1971). As groundwater inflows and spring creeks surface, the Blackfoot River gains large amounts of inflow and becomes perennial, slower moving and more sinuous. Sinuosity increases in the downriver direction as gradient decreases. Stream gradient averages $10.2 \%$ mile in this section but reaches a low of $4^{\prime} /$ mile above Nevada Creek. Lateral erosion of the forested floodplain cycles fine sediment, as well as large amounts of large woody debris into the channel. This large woody debris and woody bank vegetation is fundamentally important to channel stability and fish habitat in this alluviated channel. Fine sediment limits macro-invertebrate carrying capacity in this river section although several "clean water" species were present when last sampled in 1988 (McGuire 1989). The riparian area in this reach is largely in a healthy natural condition except for sections of Blackfoot River corridor between Highway 141 and Nevada Creek where grazing-induced erosion and weed infestations reduce riparian health (Marler and Schmetterling 1999). In 1999, water temperature monitor stations at river mile 107 and 69 recorded relatively cool stable temperatures in this reach. In August 1999, mean temperatures increased 4 degrees and did not exceed 60 degrees in this 38-mile section. 


\section{Reach 3 Nevada Creek to the North Fork: River mile 68 to 54}

Below Nevada Creek, the river becomes entrenched and confined by terminal moraine against the foothills of the Garnet Mountains where a significant change in physical stream habitat occurs. Once confined, the river acquires a more linear longitudinal profile. Furthermore, meanders decrease and channel gradient increase abruptly from $4 \%$ mile above Nevada Creek to approximately $15 \%$ mile. The river becomes laterally confined and incised up to $120^{\prime}$ in glacial deposits or bedrock. Ice rafted and glacial erratic boulders replace undercut banks and woody debris as primary habitat features.

Much of this reach occupies a geologically unstable channel subject to masswasting and naturally high erosion rates. This river section is also subject to impaired water quality originating in the Nevada Creek watershed, which enters the upper portion of this reach (McGuire 1991, Pierce et al. 1997). Fine sediments are abundant in the interstitial spaces of riffle substrates of this reach. Degraded tributaries and impaired riparian health along the river corridor further contribute to reduced water quality and low trout densities in this reach of the Blackfoot River (Peters and Spoon 1989, Ingman et al. 1990, Marler 1998, Pierce and Schmetterling 1999,).

This river section has consistently recorded higher summer-time river temperatures than all other river monitoring sites. Nevada Creek contributes to river warming (Peters and Spoon 1989, Pierce and Peters, 1990, Pierce et al. 1997). For August 1999, mean river temperatures increased from 59 to $>63$ degrees between river mile 69 and 60. Maximum stream temperatures in this river section exceeded 70 degrees, which is 5-6 degrees higher than 9 river miles upstream.

\section{Blackfoot River Trout Populations}

Reach 1 Headwaters to Lincoln, MT. In 1999, fish populations were sampled in three sections of this reach. In the downstream direction they are Below Pop's Place section (rm 128.2128.6), Flesher Pass Road section ( $\mathrm{rm}$ 124.1-124.4) and Hogum Bridge section (rm 119.5-120.3). These sections were previously sampled in the early 1970 s as well as 1988 . Based on the total 1999 electrofishing catch, brook trout $(\mathrm{n}=148)$ and cutthroat trout $(n=59)$ dominate the reach with $66 \%$ and $26 \%$ of the fish sampled, followed

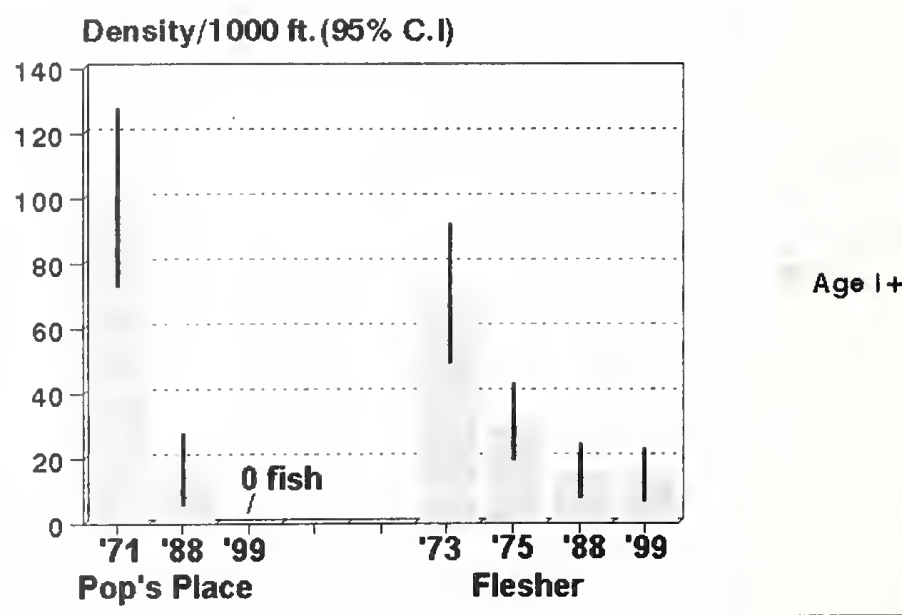

Figure 9. Estimated westslope cutthroat trout for the Pops Place and Flesher Pass Road sections.

by brown trout $(n=16)$ and bull trout $(n=1)$ which comprise the remaining $8 \%$ and $<1 \%$ of the sample, respectively. This compares to $76 \%$ brook trout $(n=383), 24 \%$ westslope cutthroat trout $(\mathrm{n}=123)$ and bull trout $(\mathrm{n}=1)$ at less than $<1 \%$ of the sample in 1988 . In 1988 , no brown trout were sampled in any of these three upper river surveys (Figure 12). 
In the Pop's Place section, densities of westslope cutthroat trout continued a trend of sharp decline that began in the 1970s (Figure 9). Between 1971 and 1988, the point estimated for age I+ westslope cutthroat trout in this section declined from 101 to 15 fish/1,000'. In 1999, no age I+ westslope cutthroat trout were found in the sampling section. Densities for age I+ brook trout declined from 55 to 39 fish $/ 1,000$ ' between 1988 to in 1999 (Figure 10).

In the Flesher Pass Road section, age $1+$ westslope cutthroat trout showed no change between 1988 and 1999 with densities of 15 and 14 fish/1,000', respectively; however, both the 1988 and 1999 westslope cutthroat trout density estimates are well below levels recorded in the 1970s (Figure 9). Age 1+ brook trout densities increased from 7 to 32 fish 1,000 ' between 1988 and 1999, comparable to densities recorded in the 1970s.

Fish population surveys in the

Density $/ 1000$ ft. (95\% C.I)

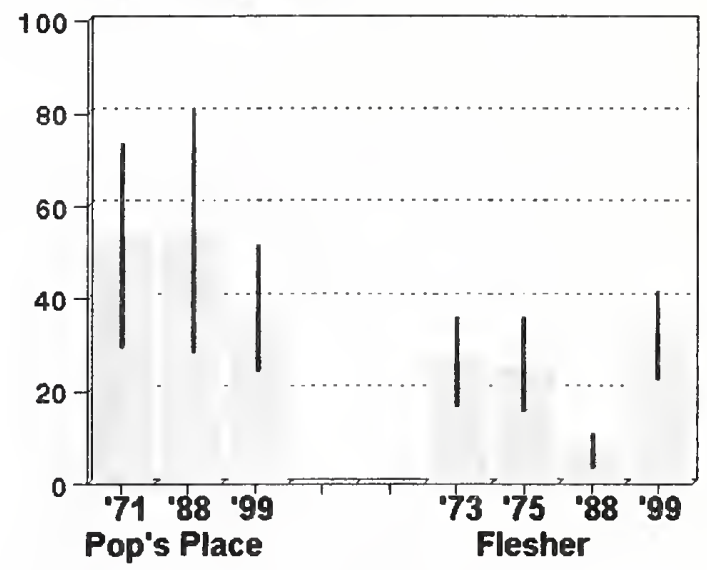

Figure 10. Estimated brook trout densities for Pops Place and Flesher Pass Road sections.

Hogum Bridge section in 1999 did not generate an estimate due to poor recapture efficiencies. However, the composition shows higher brown trout numbers than were recorded in the previous samples. The only bull trout found in any of the 1999 upper river samples was found in this section

(Appendix A).

\section{Reach 2 Lincoln, MT. to Nevada} Creek

Fish populations were also sampled in the Canyon Section (RM 94.8-95.8) in 1999, 1988 and during the 1970s. In 1999, brown trout $(\mathrm{n}=104)$ dominated the fish population comprising $88 \%$ of the sample, followed by $10 \%$ westslope cutthroat trout $(\mathrm{n}=12)$ and $2 \%$ bull trout $(\mathrm{n}=2)$. This compares with $98 \%$ brown trout $(\mathrm{n}=133), 1 \%$ westslope cutthroat trout $(\mathrm{n}=1)$ and $1 \%$ bull trout $(\mathrm{n}=1)$ in 1988 (Peters and Spoon 1989). No brook trout or rainbow

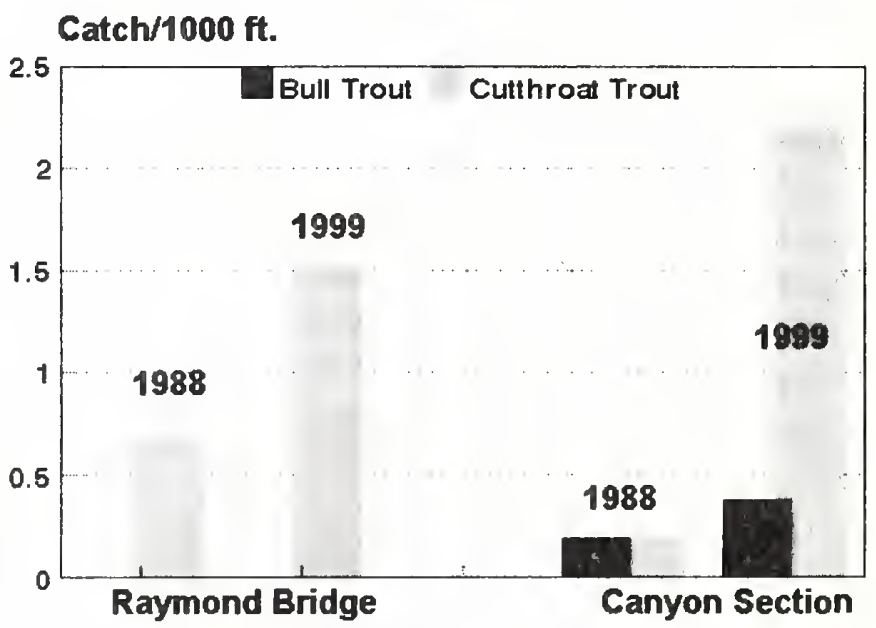
trout were found in this sample in the 1988 or 1999 surveys (figure 13).

In 1999, a reliable estimate of age I brown trout was not made. Age II and older 
brown trout (fish $>8.5$ ") densities approximately doubled between 1988 and 1999 , increasing from 15 to 31 fish $/ 1,000$ '. Although a 1999 westslope cutthroat trout estimate was not obtained, the electrofishing catch showed higher numbers than were found in 1988 (Figure 11).

\section{Reach 3 Nevada Creek to the North Fork}

In 1999, we re-sampled trout populations in the Raymond Bridge section, located between river mile 58.9 and 60.0. This 1.1-mile section was established and last surveyed in 1988. This sample location represents the uppermost section that rainbow trout have been observed. The 1988 sample consisted of $71 \%$ brown trout $(\mathrm{n}=32), 20 \%$ rainbow trout $(n=9)$, and $9 \%$ cutthroat trout $(\mathrm{n}=4)$, compared to $67 \%$ brown trout $(\mathrm{n}=35), 17 \%$ rainbow trout $(\mathrm{n}=8)$ and $15 \%$ westslope cutthroat trout $(\mathrm{n}=8)$ in 1999 (Figure 13). Of eight westslope cutthroat trout sampled, five showed signs of being released Density $1000 \mathrm{ft}$.

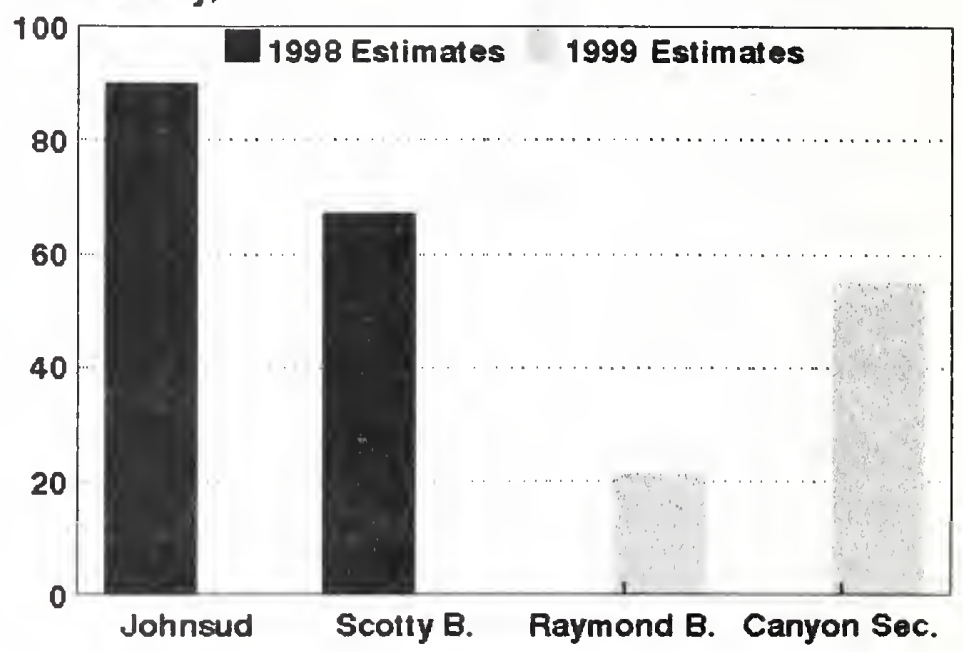

by anglers.

This reach of river supports the lowest trout densities in the Blackfoot River between Lincoln and the mouth of the Blackfoot River (Figure 12). Total trout densities (fish $>6.0^{\prime \prime}$ ) were estimated at $21.2 \mathrm{fish} / 1,000^{\prime}$. Brown trout (fish $>6.0^{\prime}$ ) densities were estimated at 10.8 fish $/ 1,000$ '. Low sample numbers for rainbow and cutthroat trout prevented density estimates for these two species. No YOY or age I trout were found in the 1999 sample. The composition of the 1999 catch was very similar to the 1988 sample although westslope cutthroat trout were better represented in the 1999 survey. No bull trout or brook trout have been documented in this section of river (Figure 13). 
Figure 13. Species composition for Blackfoot River Fish at five upper Blackfoot River Sampling locations, 1988 and 1999.
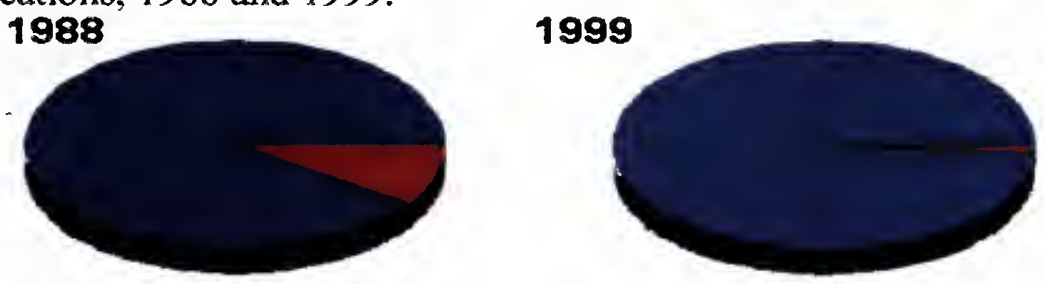

\section{Pops Place Section}
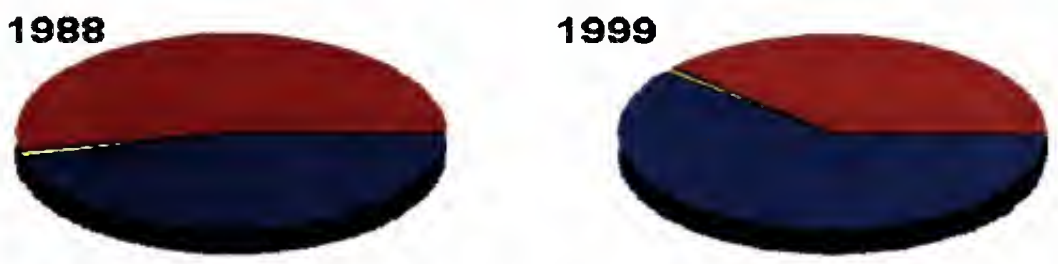

Flesher Pass Road Section
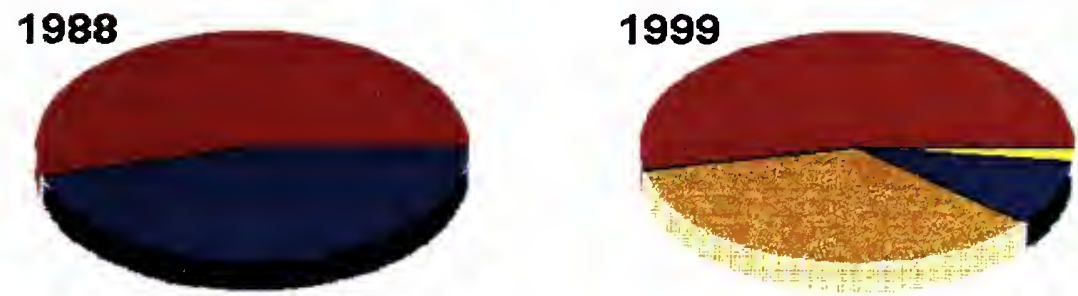

\section{Hogum Bridge Section}
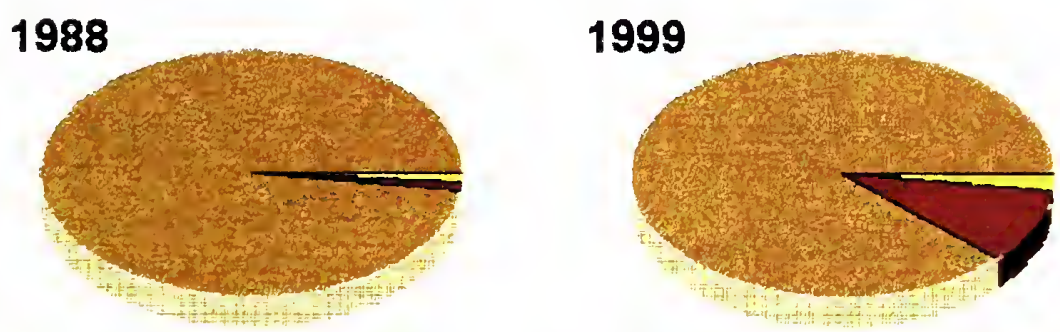

\section{Canyon Section}
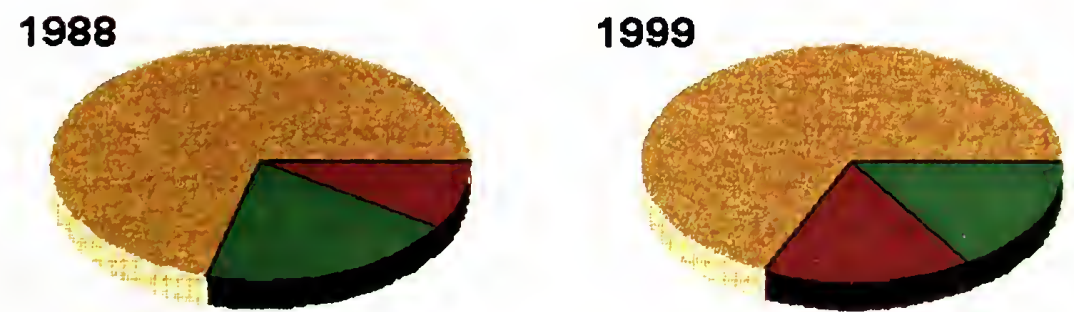

Raymond Bridge Section

Cutthroat Trout Bull Trout
Brown Trout
Brook Trout




\section{Part II: Fisheries Inventories in Tributaries to the Upper Blackfoot River}

Part II summarizes 1999 fish sampling results and habitat observations for 13 tributaries to the upper Blackfoot River. Most of these tributaries have received limited past fisheries inventory work particularly at lower elevations. Westslope cutthroat trout genetic samples were taken from all 13 tributaries; genetic results are presented by tributary in this section, as well as in Part IV and in Appendix J.

\section{Alice Creek}

Alice Creek, a $2^{\text {nd }}$ order tributary to the upper Blackfoot River, drains the western slopes of the Continental Divide near Red Mountain in the Helena National Forest and flows 15.5 miles before merging with the upper Blackfoot River at river mile 122.8. Stream gradient ranges from $360 \%$ mile between stream mile 15.0 and 14.0 to $20 \%$ mile between stream mile 8.0 and 7.0. Stream gradient increases downstream of mile 7.0 where gradient ranges from 40-80\% $/ \mathrm{mile}$. Land ownership in the lower nine miles of stream is mixed private and state land (Figure 14).

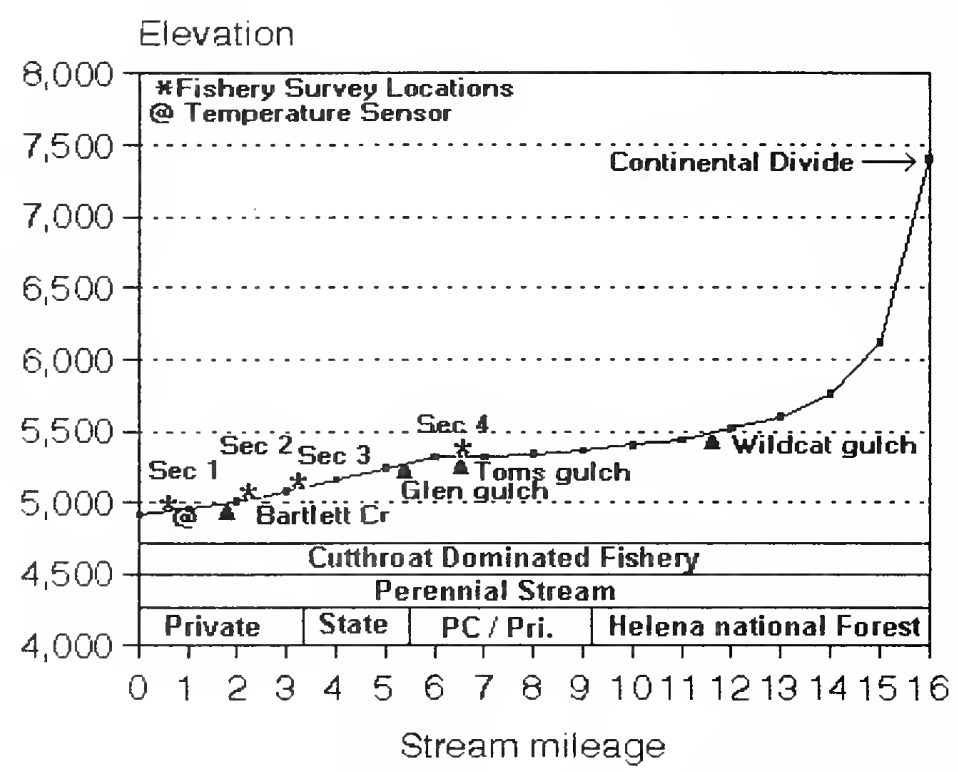

Fish populations were sampled at four locations in Figure 14. Longitudinal profile for Alice Creek the lower seven miles of stream. At mile 0.6 , the riparian area near the survey section was healthy with no observed signs of stream degradation. Natural bank erosion from stream channel migration has recruited some timber to the stream channel.

The second and third survey sections were located at the stream mile 2.0 and 3.1, respectively. Riparian vegetation at both sites consists of a conifer/ cottonwood overstory above an understory of willow, alder, and dogwood with sedge communities along the immediate banks. Overall the stream banks are stable, although the stream lacks instream woody structure, and pool development is poor. Recruitment of large woody debris to the channel is minimal. Low natural stream flows may be a limiting factor in lower Alice Creek.

At survey section 4 , located at stream mile 6.2, stream gradient declines. The flood plain is considerably wider, noticeably slowing the water velocity in this section. The survey has very deep pools with heavy levels of fine sediment. Riparian vegetation consists primarily of shrub and sedge communities.

A thermograph placed near the mouth of Alice creek in the summer of 1999 recorded maximum August temperatures of 57 degrees, which was cooler than five 

downstream tributaries to the Blackfoot River (Appendix $\mathrm{H}$ ).

Observed problems were limited to an instream road crossing and localized degradation of stream banks at campsites at stream mile 1.7.

\section{Fish Populations}

The lower two fish population survey sites produced no fish; however, two westslope cutthroat trout $>4$ " were observed in the $2^{\text {nd }}$ survey section. Low numbers of YOY were also observed in both sections, but were not identified to species. At the $3^{\text {rd }}$ survey site, we recorded a total westslope cutthroat trout CPUE of 0.5 fish $/ 100$ '; deep pools prevented efficient sampling using a backpack electroshocking unit at this site. Sculpins were common in all transects except $4^{\text {th }}$ survey section. Spotted frogs were also present. Only small numbers of YOY were observed in each sample site.

\section{Arrastra Creek}

Arrastra Creek, the largest tributary between the Beaver Creek and Nevada Creek, enters the Blackfoot River at river mile 88.8. It is the only known stream between Poorman Creek and the North Fork to support bull trout reproduction. Restoration opportunities have not been well documented in Arrastra Creek with the exception poor road building and road crossings including culverts in the upper and lower portion of the mainstem. A thermograph placed in lower Arrastra Creek recorded the lowest maximum stream temperature of five tributaries downstream of Alice Creek (Appendix $\mathrm{H}$ ).

Fish Populations

Arrastra Creek supports a mixed fish population in the lower reaches and native species in upper reaches (Figure 15).

Arrastra Creek supports limited bull trout reproduction. Spawning locations have not been identified although juveniles bull trout are found throughout the stream in low densities. Westslope cutthroat trout genetic testing of 25 fish show no introgression.

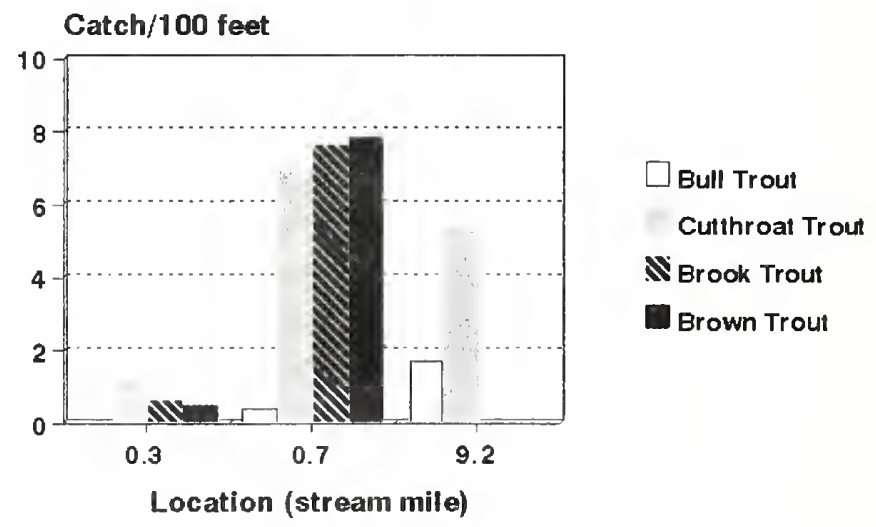

Figure 15. CPUE for fish $>4.0$ " in three sections of Arrastra Creek 1999.

\section{Bartlett Creek}

Bartlett Creek is a $1^{\text {st }}$ order tributary to Alice Creek entering at stream mile 1.9. Stream gradient ranges from $160^{\prime} /$ mile between stream mile 6.0 and 5.0 and $80 \%$ mile between stream mile 2.0 and 1.0 before increasing to $160 \%$ mile in the lower mile of stream. The very upper reaches of Bartlett Creek drain National Forest land on the very western edge of the Continental Divide. The stream flows southwest 6.7 miles through Plum Creek Timber Company property and other private inholdings before entering Alice Creek at stream mile 1.8 (Figure 16). 


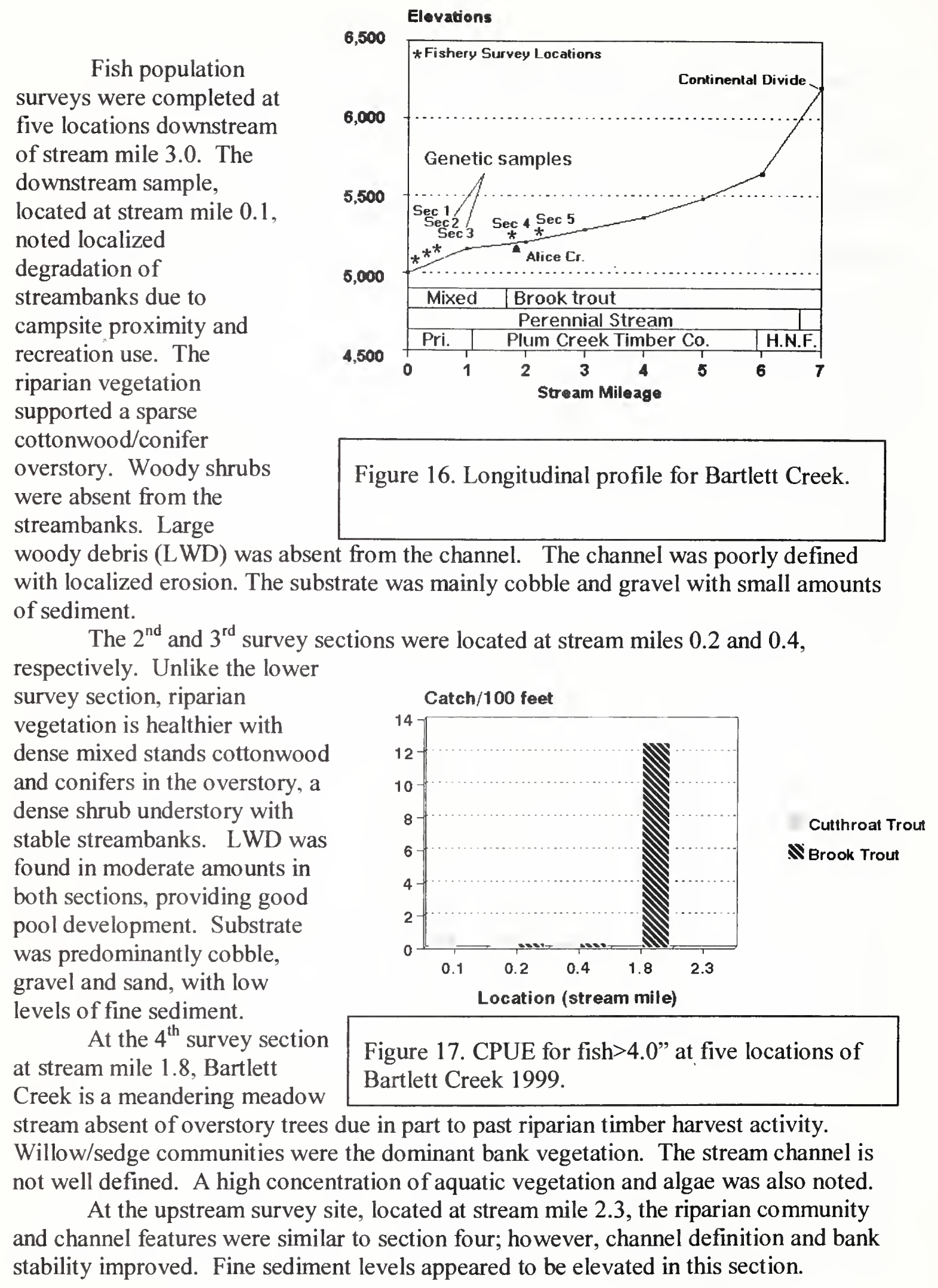

Fish Populations

Fish densities were low for both westslope cutthroat trout and brook trout (Figure 
17). One YOY brown trout was found in lower Bartlett. A westslope cutthroat trout genetic sample taken from 14 fish in lower Bartlett Creek recorded low-level introgression with $98.8 \%$ westslope cutthroat trout and $1.2 \%$ rainbow trout.

Low densities of westslope cutthroat trout, including YOY, were found from samples taken in the lower mile of stream but absent from the two upper sites. Where present westslope cutthroat trout (fish $>4.0$ ") CPUE ranged from 0.4 to 0.8 . Brook trout CPUE (fish $>4.0$ ") showed a sharp increase between stream mile 0.4 and 1.8 but then declined at stream mile 2.3. Sculpins, spotted frogs and western toads were observed in Bartlett Creek.

\section{Beaver Creek}

Beaver Creek, a $3^{\text {rd }}$ order tributary to Keep Cool Creek, enters at 0.7 miles upstream of the Keep Cool Creek confluence with the Blackfoot River ( $r m$ 105.2). The land ownership in the Beaver Creek watershed varies from Helena National Forest and state trust land in the headwaters to private agricultural ranchland in the lower basin, along with a few housing developments near Highway 200.

We sampled Beaver Creek at the three sample locations established in 1989. The $1^{\text {st }}$ survey at stream mile 1.0 found overall healthy riparian with an cottonwood/conifer overstory above a juniper/shrub understory. Fish habitat varied between deep pools, runs with under cut banks with a moderate amount of LWD. Substrate was composed of boulder, cobble and gravel. Fine sediment levels appeared to be elevated.

The $2^{\text {nd }}$ survey site at mile 2.1 is located downstream of large wetland complex. The riparian vegetation consists willows and sedge communities. Immediate streambanks showed signs of heavy livestock use and instability. Shrubs appeared to be suppressed. The channel continued through a stockyard. The substrate composed of cobble and gravel with elevated levels of fine sediment.

The $3^{\text {rd }}$ survey site was located on Helena National Forest at stream mile 6.6 upstream of the Lincoln Ditch Bridge. The riparian area in this section was heavily forested with conifer overstory above an alder dominated understory. Large woody debris recruitment and shade to stream are both excellent. Banks are stable and minimal erosion was noted. The substrate consisted of cobble, gravel, and some boulders. Some upwelling/springs at this survey site were noted.

\section{Fish Populations}

Brown trout dominate in the lower reaches and westslope cutthroat trout dominate headwater areas upstream of a the wetland complex. Brook trout inhabit the mid- to upper reaches of Beaver Creek. The 1999 Beaver Creek samples duplicated 1989 sections (Peters 1990). All species at all locations were at lower densities in 1999 compared to 1989 (Figure 18). In 1999, brown trout densities (fish $>4.0$ ") declined in the upstream direction with a CPUE decreasing from 2.8 to 2.0 between mile 0.1 and 2.1. Brook trout were found in the middle and upper portions of Beaver Creek in low densities. The highest fish densities were found in the headwaters where westslope cutthroat trout (fish $>4.0$ ") recorded a CPUE of 7.4. A westslope cutthroat genetic sample $(\mathrm{n}=25)$ taken at stream mile 6.5 indicate a pure population. Sculpins and longnose suckers were also recorded in Beaver Creek. 


\section{Copper Creek}

Copper Creek, a major tributary to the lower Landers Fork, is a spawning and rearing stream for westslope cutthroat trout and fluvial bull trout (Swanberg and Burns, 1997). It supports the only major spawning migration of fluvial bull trout in the upper Blackfoot Basin.

Copper creek had the coldest summer stream temperatures of any of the sampled streams in the Blackfoot Watershed in 1999. Cold stream temperatures reduce temperatures in the Lower Landers Fork and in the Blackfoot River below the Landers Fork.

\section{Fish Populations}

Catch/100 feet

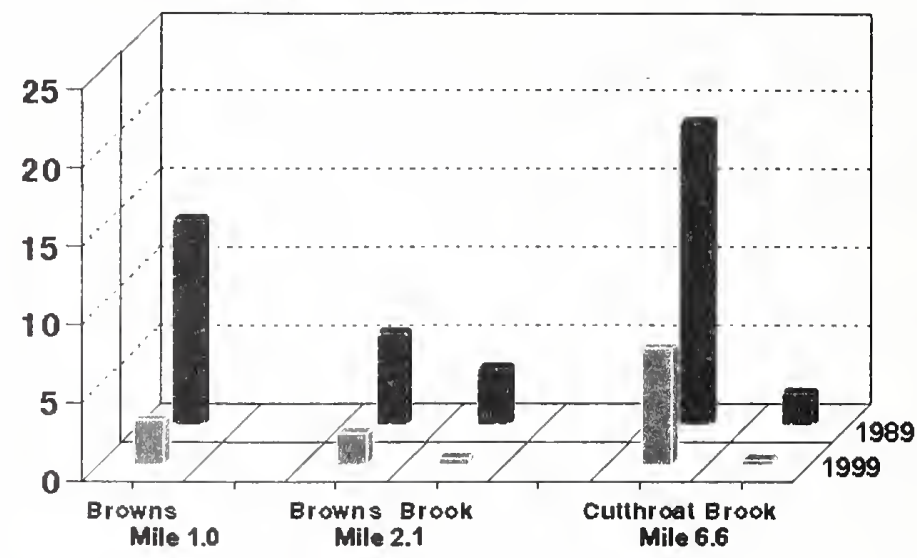

Figure 18. CPUE for fish $>4.0$ " at three locations of Beaver Creek, 1989 and 1999.

Copper Creek supports s only native fish species over its entire length (Peters 1990, Chapman and Hillman 1996). In 1999, we resurveyed four fish population survey sites originally established in 1989 (Peters 1990). Sample locations ranged from the lower Copper Creek at mile 1.1 to the headwaters at mile 10.8. Bull trout and westslope cutthroat trout were recorded at all surveyed locations. The CPUE of bull trout (fish $>4.0^{\prime \prime}$ ) ranged from 0.3 to $2.3 \mathrm{fish} / 100$ ' with the higher catch rates occurring in the mid- to upper portion of the basin. A comparison of the 1989 (CPUE of 1.9) and 1999 (CPUE of 1.9) samples recorded no improvement in juvenile bull trout numbers. The CPUE of westslope cutthroat (fish $>4.0^{\prime \prime}$ ) ranged from 0.2 to 2.8 fish/100. A westslope cutthroat trout genetic sample $(\mathrm{n}=25)$ found no introgression.

\section{Hogum Creek}

Hogum Creek, a $2^{\text {nd }}$ order stream, entering the Blackfoot River at river mile 119.2 (Figure 19). Stream gradient ranges from $600 \%$ mile between stream 6.0 and 5.0 and $80 \%$ mile in the lower mile of stream. The headwaters of Hogum Creek drain the Helena National Forest. Private land is found along the lower two miles of stream. In 1999, Hogum Creek was sampled in three locations, all of which were located in the lower mile stream due to limited access. 
At the lower-most survey section, stream banks were generally stable although some streamside grazing increased channel width and reduced depth in one area.

Substrate in this section was

cobble and gravel.

The $2^{\text {nd }}$ survey was

located at stream mile 0.4 below a beaver complex. The creek meandered through a meadow in this section. Substrate was cobble and gravel with higher amounts of gravel and fine sediment. Overstory was more open with alder and willow along streambanks. Conifer and sedge communities provided some shade and bank stability in this section. We noted dense algae growth and deep pools and beaver activity. Some LWD was present in the channel.

The upstream sample was located at stream mile 0.7 . The

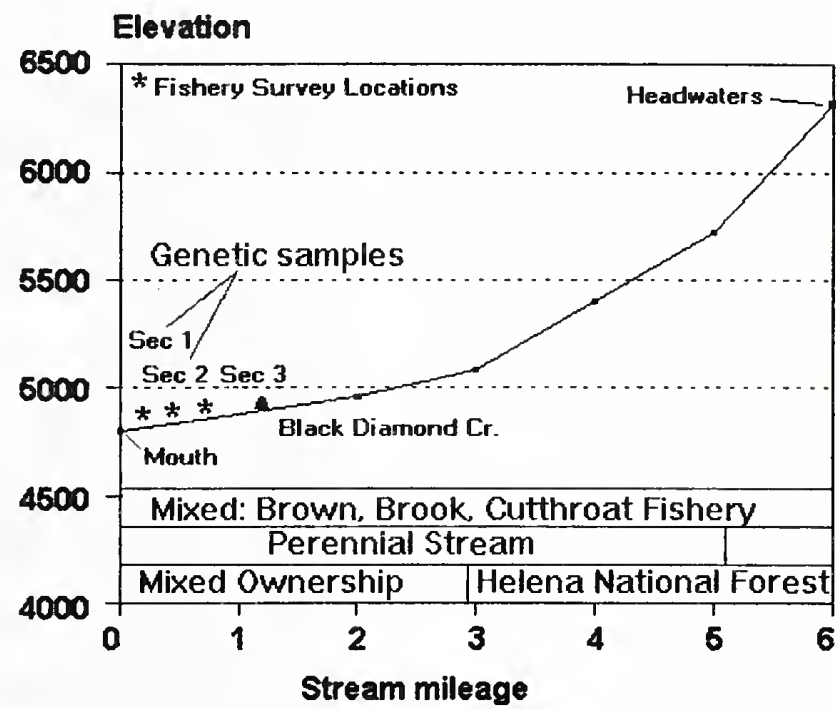

Figure 19. Longitudinal profile for Hogum Creek. riparian zone in this section appeared healthy. Streambank stability improved due to increasing density of shrubs. Large woody debris was present in the channel. The substrate was predominantly cobble and boulder.

A culvert that may present a problem for fish was noted in lower Black Diamond Creek, a tributary to Hogum Creek, entering at stream mile 1.2.

\section{Fish Populations}

Three fish population surveys were completed in the lower 0.7 miles of stream. Brook trout and westslope cutthroat trout co-dominate lower Hogum Creek. Densities of fish $>4.0$ " increased upstream of the mouth. The CPUE for westslope cutthroat trout (fish $>4.0^{\prime \prime}$ ) increased in the upstream direction from 0.3 to $3.2 \mathrm{fish} / 100$ '. Brook trout (fish $>4.0^{\prime \prime}$ ) were absent from the sample immediately upstream of the mouth but were collected at both upstream samples with a CPUE ranging from 1.5 to 2.5 fish/100'. Brown trout (fish $>4.0^{\prime \prime}$ ) were found in low numbers with CPUE ranging from 0.2 to 0.3 fish/100'. Genetic testing of the westslope cutthroat trout $(n=25)$ in these lower samples found mild introgression with a $99.3 \%$ level of purity.

\section{Landers Fork}

The Landers Fork, the largest tributary to the upper Blackfoot River, enters at river mile 116.1. The Landers Fork approximately doubles the flow of the Blackfoot River at base flow periods. In 1998, the Landers Fork averaged five degrees cooler than the Blackfoot River with much of the cooler waters originating from the Copper Creek drainage (Pierce and Schmetterling 1999). In the 1970s, the Landers Fork was the focus of a woody debris "cleaning" effort which included channelization upstream of Highway 
200 (FWP files). Today these sections of the channel are unstable in areas of past alterations and upstream of bridges which appear to be undersized. Downstream of Highway 200, channel stability and habitat complexity appears to be improving in the lower mile of the Landers Fork with channel definition and early succession plant communities becoming established on the floodplain. The Landers Fork seasonally goes intermittent in area of the Copper Creek confluence.

\section{Fish Populations}

The Landers Fork supports low numbers of juvenile native fish and very low numbers of non-native fish. Below Silver King Falls, a natural barrier at river mile 8.3, the lower Landers Fork historically supported bull trout spawning (FWP unpublished data). This

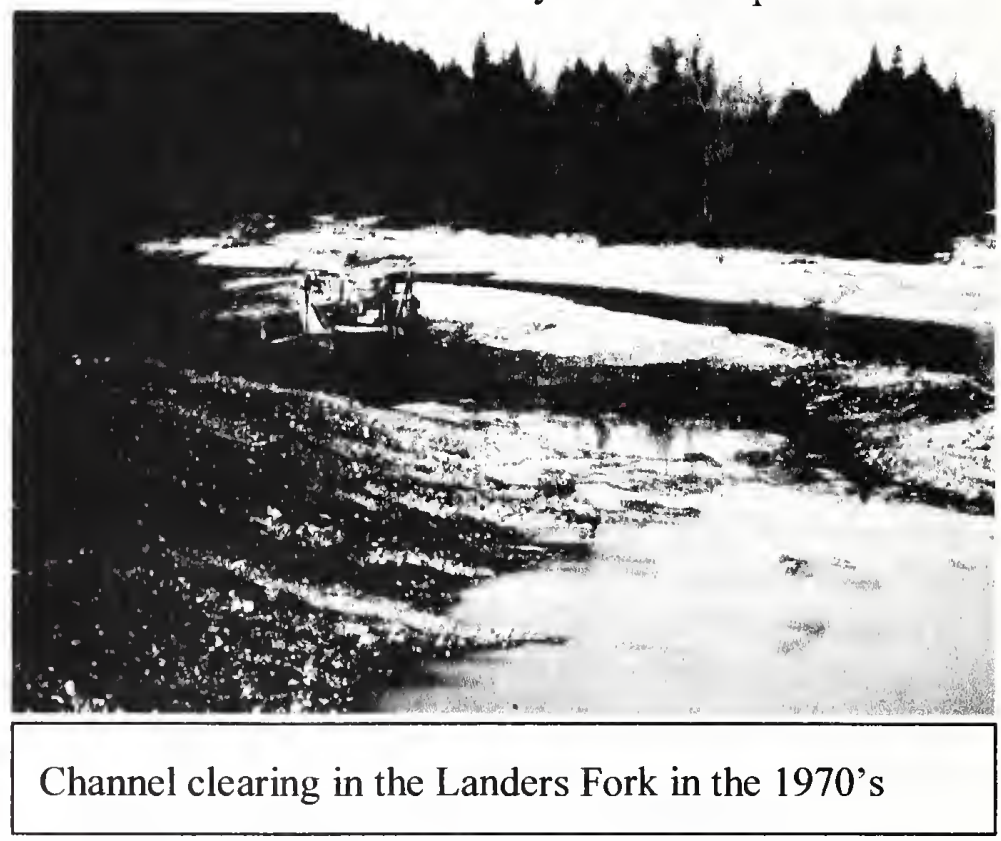
lower reach provides rearing habitat and a migration corridor plus wintering areas for adult Blackfoot River fluvial bull trout which reproduce in Copper Creek (Chapman and Hillman 1996, Swanberg and Burns 1997).

In 1999, three fish population survey sections, established in 1989, were resurveyed. Fish collected in the Landers Fork were juvenile bull trout or westslope cutthroat trout, with the exception of one brown trout sampled at stream mile 4.6. No brook were found in any of the samples. For both westslope cutthroat trout and bull trout (fish >4.0") CPUE, although low, improved comparison with 1989 (Figure 20). No YOY or adult fish were collected in 1,700' of sampled stream. Genetic testing of westslope cutthroat trout has been undertaken at several locations in the last decade. All past genetic samples from the Landers Fork basin including the 1999 sample $(n=7)$ have recorded no

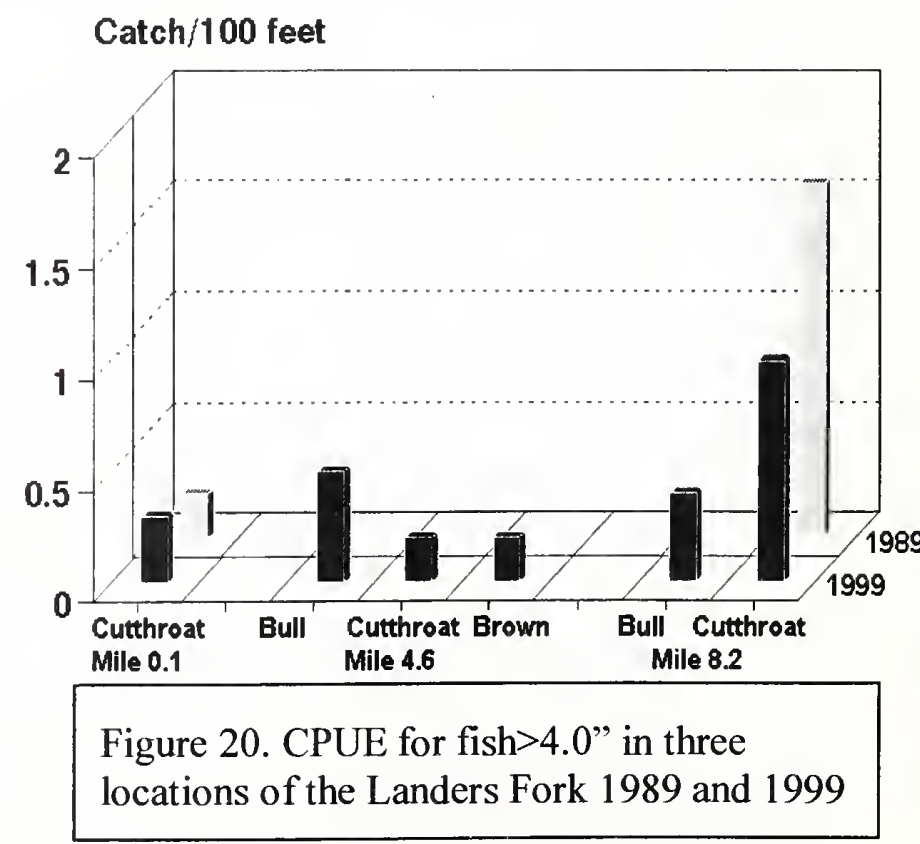
introgression (Appendix J). However, according to the Helena National Forest, a pure 
population of Yellowstone cutthroat trout is established in Big Horn Lake, located in the headwaters of the Landers Fork upstream of Silver King Falls (L. Burns, personal communication).

\section{Moose Creek}

Moose Creek, a $1^{\text {st }}$ order tributary to the Blackfoot River at river mile 94.3 , was sampled at two locations in August 1999 (Figure 21). Stream gradient ranges from $660 \%$ mile between stream mile 4.0 and 3.0 and $100 \%$ mile between stream mile 1.0 and the mouth. Moose Creek lies in Helena National Forestland except for a small section of private land near the mouth. Moose Creek was sampled at two locations, upstream and downstream of the Ogden Mountain Road at stream mile 0.4 . At both sites, substrate

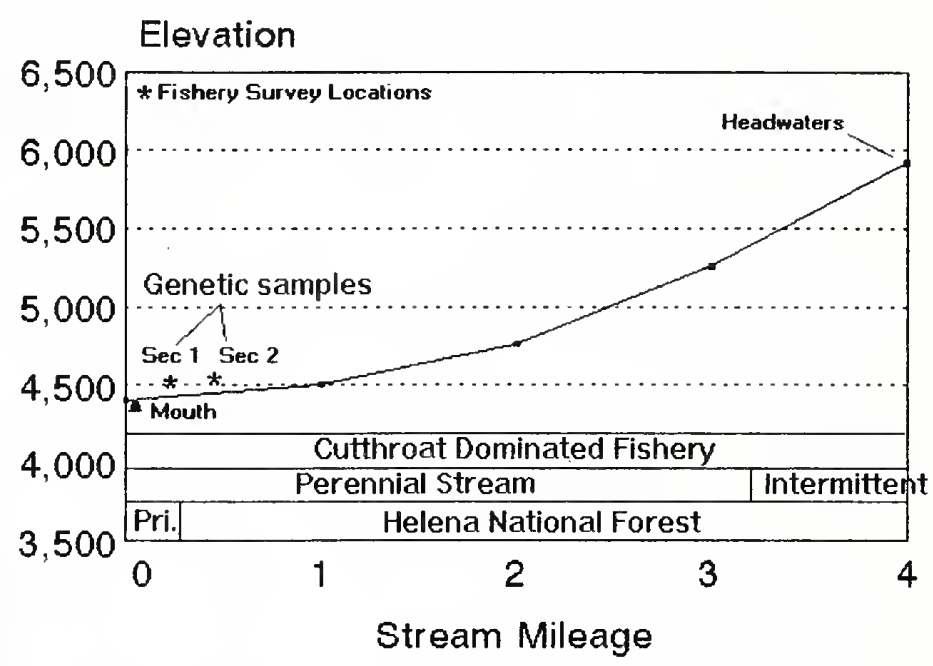

Figure 21. Longitudinal profile for Moose Creek. consisted of cobble, with gravel and sand. Conifers and cottonwood dominated the overstory vegetation. As a result, the stream was well shaded and LWD was abundant in the channel. Overall, fish habitat was good with a variety of pools and cover present. Alder and small second-growth conifers comprise the riparian understory. The channel was well established and stream banks were relatively stable. The culvert appears to be undersized. Livestock access resulted in localized areas of stream bank degradation downstream of the culvert.

\section{Fish Populations}

Westslope cutthroat trout were the only fish species recorded at both sampling sites. Genetic testing of these fish $(\mathrm{n}=25)$ recorded a low incidence of $(0.8 \%)$ introgression between westslope cutthroat trout and rainbow trout. The hybrid fish was found upstream of the culvert. Westslope cutthroat trout (fish $>4.0^{\text {") }}$ ) ranged from 3.9 to 5.4 fish/100'. Westslope cutthroat trout YOY were well represented in the sample. We also observed spotted frogs and western toads.

\section{Poorman Creek}

Poorman Creek, a 3rd order tributary, flows 14 miles to its confluence with the Blackfoot River at river mile 108. Upper Poorman Creek is an area of historic placer mining activity. Land use includes small private inholdings in the middle reaches and agricultural ranching in lower Poorman Creek.

We sampled fish at stream mile 0.1, 4.0, and 7.4. For lower Poorman Creek, the riparian zone is a meadow-type, composed of grassy banks mixed with sparse willow 
growth and mature cottonwood stands. Streambanks showed clear signs of excessive livestock access. Other observed potential problems include culvert placements and fish in irrigation ditches. We noted that the predominantly gravel substrate contains high levels of sediment.

At the $2^{\text {nd }}$ survey, the riparian vegetation varied from mature cottonwood and mixed conifer communities to willow-lined banks to upland grasses. Streambank stability. and habitat complexity was also variable.

The $3^{\text {rd }}$ survey site was located on Helena National Forest at stream mile 7.4. The overstory is conifer-dominated forest with a shrub and sedge understory. The stream is confined and well armored with bedrock, boulder and cobble substrate with adequate amount of LWD. Deep pools created by large woody debris and smaller cascading pools are present.

During these surveys, other problems we observed include: placer mining activity in the headwaters, localized areas where Stemple Pass Road is sloughing into Poorman Creek and possible culvert barriers on the mainstem. In addition, we completed an extensive survey of potential restoration opportunities in the lower 2.2 miles Poorman Creek. This

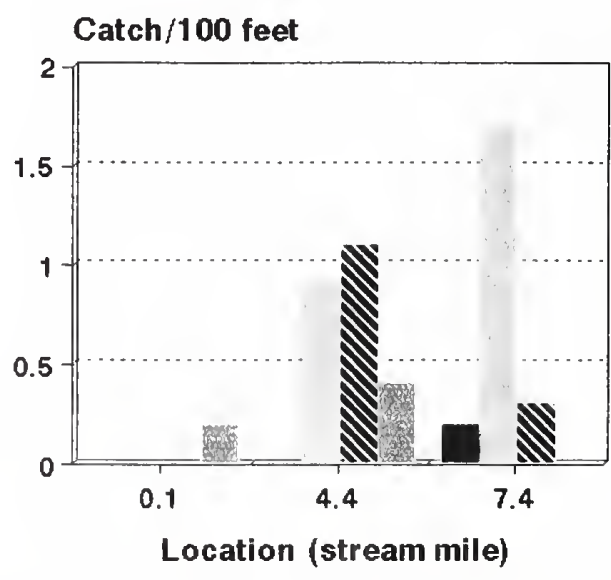

Figure 22. CPUE for fish $>4.0$ " at three locations of Poorman Creek 1999.

assessment is available at Montana Fish, Wildlife, and Parks, Missoula, Montana.

\section{Fish Populations}

The lower fish

population survey section at stream mile 0.1 produced low brown trout numbers with a CPUE of $0.2 \mathrm{fish} / 100$ '. Deep pools $\left(>5^{\prime}\right.$ deep) prevented efficient sampling although juvenile brown trout and westslope cutthroat trout were observed at this site.

A mixed fish community at the $2^{\text {nd }}$ survey produced a CPUE (fish $>4.0$ ") of $0.9,1.1$, and 0.4 fish $/ 100^{\prime}$ for westslope cutthroat trout, brook trout and brown trout

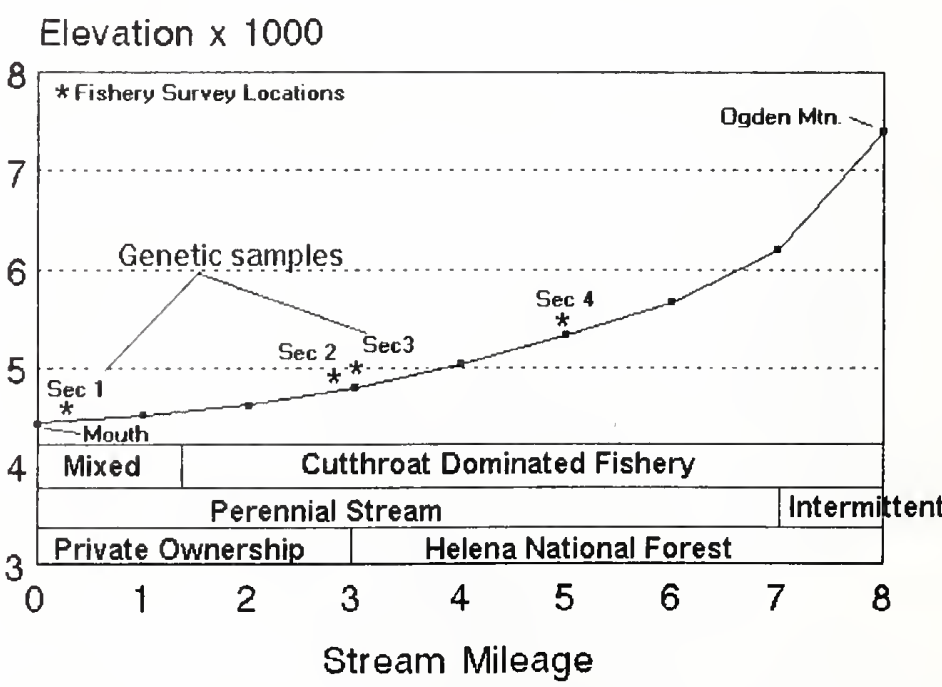

Figure 23. Longitudinal profile for Sauerkraut Creek. 
respectively. The $3^{\text {rd }}$ sample recorded increasing westslope cutthroat trout densities, lower brook trout densities and very low bull trout densities (Figure 22).

Results from westslope cutthroat trout genetic testing $(n=25)$ from Poorman Creek showed no introgression.

\section{Sauerkraut Creek}

Sauerkraut Creek, a $1^{\text {st }}$ order tributary, enters the Blackfoot River at river mile 102.1. Stream gradient ranges from to $530 \%$ mile between stream mile 7.0 and 6.0 and $80 \%$ mile in the lower mile of stream. Sauerkraut Creeks has approximately 7 miles of perennial stream, the headwaters of which are found on the Helena National Forest. The lower 3 miles of stream is located on private land (Figure 23).

Fish population surveys were completed at 4 locations. The riparian habitat of the lower section appeared to be in good heath with conifers dominating the overstory and a dense shrub understory. Large woody debris (LWD) was moderate and streambanks were generally stable. The stream in the lower reaches contained a gravel base with elevated levels of fine sediment. We noted one misalignment culvert at a private road crossing.

At the $2^{\text {nd }}$ and $3^{\text {rd }}$ survey sites, we noted signs of excessive livestock use in the riparian area and sections of degraded stream due to a instream road crossing, gravel mining activities and physical alterations to approximately 750 ' of channel. We observed the stream went sub-surface near the rock/gravel operation.

The middle and upper most reaches of the Sauerkraut Creek lies entirely on Helena National Forest. In this section, the stream flows through a healthy riparian area. The channel is confined with stable banks. Large woody debris recruitment is sufficient and cascading pools provide excellent fish habitat. A more complete assessment of lower Sauerkraut Creek is available at Montana Fish, Wildlife, and Parks, Missoula, Montana

\section{Fish Populations}

We sampled fish populations at four locations on Sauerkraut Creek in 1999. The $1^{\text {st }}$ section, near the mouth of Sauerkraut Creek, produced the highest overall fish densities, which included the presence of bull trout (Figure 24).

The $2^{\text {nd }}$ survey sampled at stream mile 2.7 recorded the lowest densities, which included YOY westslope cutthroat trout and brook trout. The $3^{\text {rd }}$ and $4^{\text {th }}$ surveys recorded increased densities of westslope cutthroat trout and continued decline in brook trout densities. The $3^{\text {rd }}$ survey recorded 4.4 fish $/ 100$ ' for westslope cutthroat trout and 0.3 fish/100' for

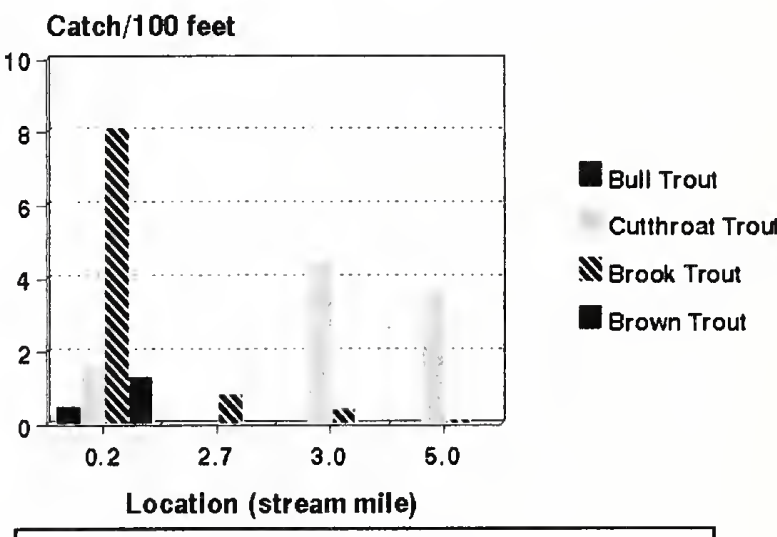

Figure 24. CPUE for fish $>4.0$ " in four locations of Samerkraut Creek 1999

brook trout. The $4^{\text {th }}$ survey produced a westslope cutthroat trout CPUE (fish $>4.0$ ") of 3.6 and 0.1 for brook trout. The highest densities of brook trout YOY were found in the 
lower reaches of Sauerkraut Creek while the highest westslope cutthroat trout YOY densities were found at the higher elevations. The westslope cutthroat trout genetic sample $(n=24)$ results detected no introgression.

\section{Seven-Up-Pete Creek}

Seven-Up Pete Creek is a $1^{\text {st }}$ order tributary enters the Blackfoot River between river mile 115.6 (Figure 25). Stream gradient ranges from $620 \%$ mile between stream mile 4.0 and 3.0 and $120 \%$ mile between in the lower mile of stream. This stream is found mostly on Helena National Forest with its headwaters draining the Crater Mountain area. Mines and other private inholding are scattered throughout in the headwater areas. The lack of roads limited access to the stream. As a result, two consecutive stream surveys immediately upstream from the mouth were sampled.

Riparian habitat in both

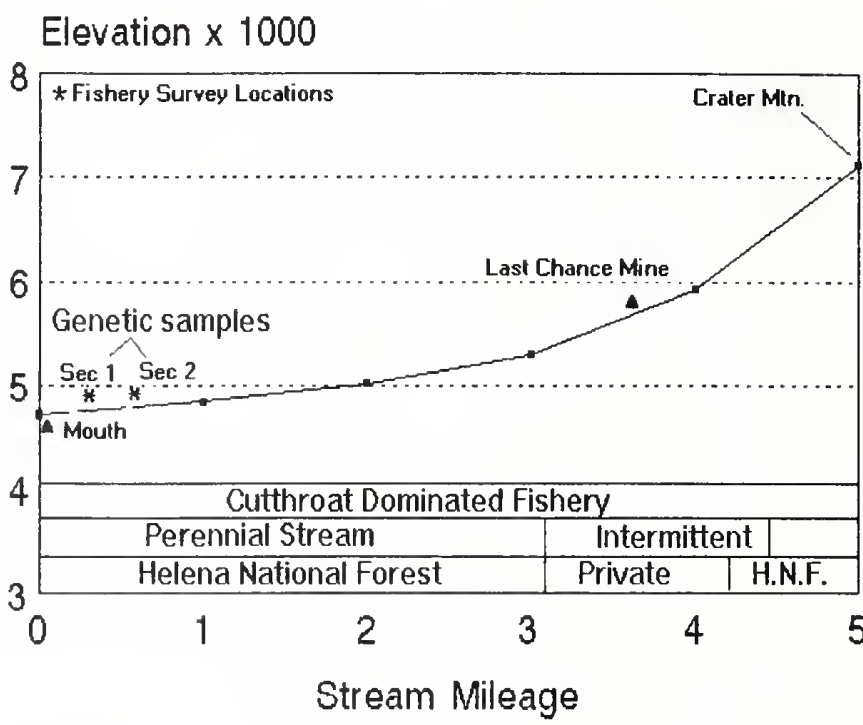

Figure 25. Longitudinal profile for Seven-upPete Treek survey locations was in good health. Conifers dominated the overstory with an alder and willow in the understory. The stream was confined and banks were quite stable. Recruitment of LWD appeared sufficient. The substrate was composed primarily of cobble with lesser amounts of gravel.

The only problem observed was an all-terrain vehicle trail cutting through the stream channel several times as it continued up the drainage. Bank degradation and erosion was evident at the crossings, but impacts were limited.

\section{Fish populations}

The Seven-up-Pete Creek fish surveys revealed westslope cutthroat trout as the dominant species but at very low numbers (Figure 26). The CPUE for westslope cutthroat trout (fish $>4$ ") at both survey sites was low at 0.8 and 0.5 fish $/ 100$ ' for the lower and upper sites, respectfully. Only 2 brook trout (fish $>4$ ") were sampled in the lower survey, producing a low CPUE of 0.1 . Brook trout were absent from the upstream survey. In both surveys, low numbers of YOY were observed and adult

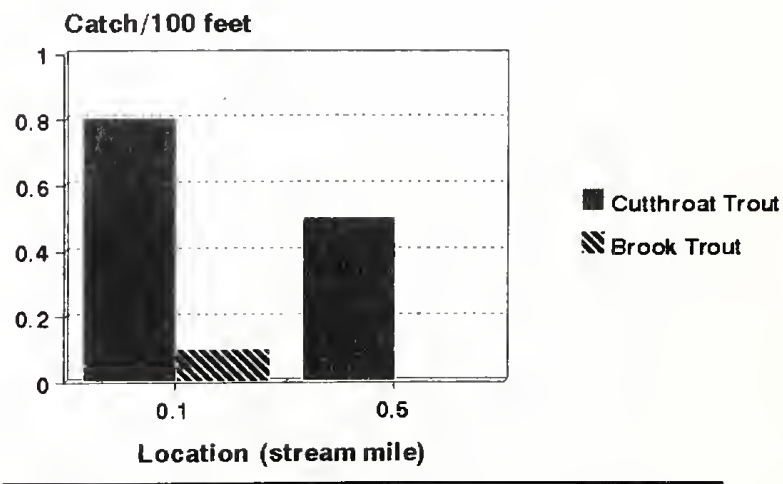

Figure 26. CPUE for fish $>4.0$ " in Seven up Pete Creek 1999. 
spotted frogs were present. Genetic test results $(\mathrm{n}=25)$ indicate the westslope cutthroat trout is not hybridized.

\section{Willow Creek (below Lincoln)}

Lower Willow Creek is a $2^{\text {nd }}$ order tributary to the Blackfoot River. Stream gradient below the confluence of the West Fork ranges from $200 \%$ mile between stream mile 6.0 and 5.0 to $20 \%$ mile between stream mile 1.0 and the mouth. Land ownership on the lower 6 miles of stream is mixed private which includes Plum Creek Timber Company. The upper basin is found Helena National Forest (Figure 27). In 1999, we surveyed five sections in the drainage, including the mainstem Willow Creek at stream miles $1.8,5.1,5.7$, and two upstream tributary sites located immediately upstream of the East Fork and West Fork confluences (Figure 27).

The riparian vegetation

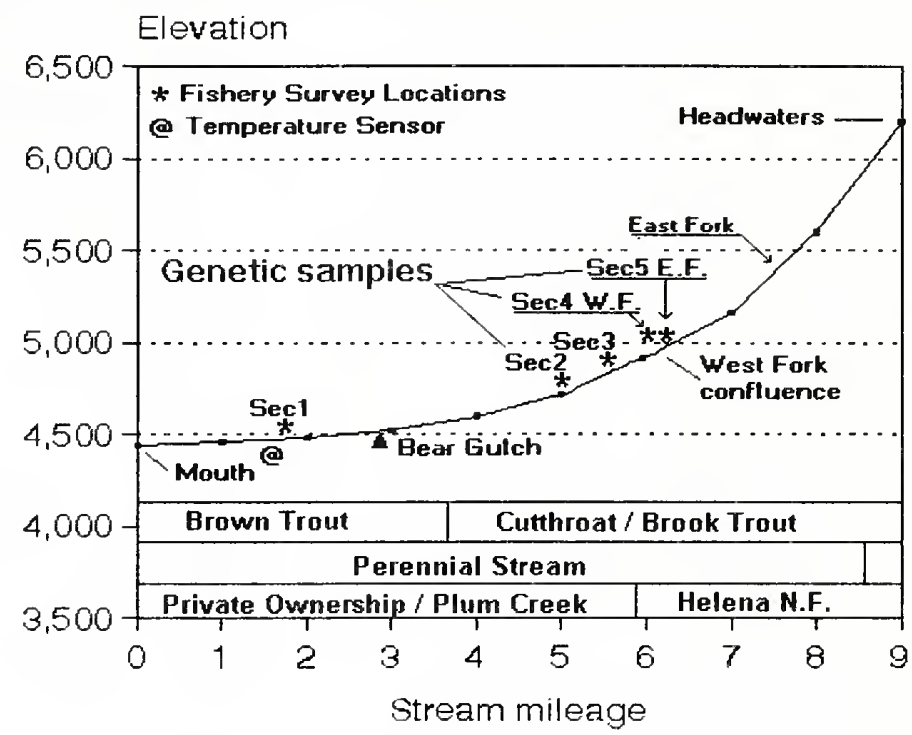

Figure 27. Longitudinal profile for Willow Creek below Lincoln.

varies between the upper and lower watershed. In the lower reaches, the stream meanders through pastureland. The riparian vegetation consists of willow and sedge communities. The substrate consists of gravel with noticeably high levels of fine sediment. The surveys noted possible grazing impacts in the lower to middle stream reaches. In the middle reaches, the riparian habitat changes from pasture to a conifer overstory with an alder understory. LWD increased in the channel and the substrate is composed primarily of cobble and fine sediment. On Helena National Forest, the riparian was generally in good health and LWD recruitment appeared sufficient.

Of six monitored tributaries upstream of Nevada Creek, Willow creek recorded the highest stream temperatures, exceeding 67 degrees in August which was approximately 5 degrees warmer than the Blackfoot River near Lincoln

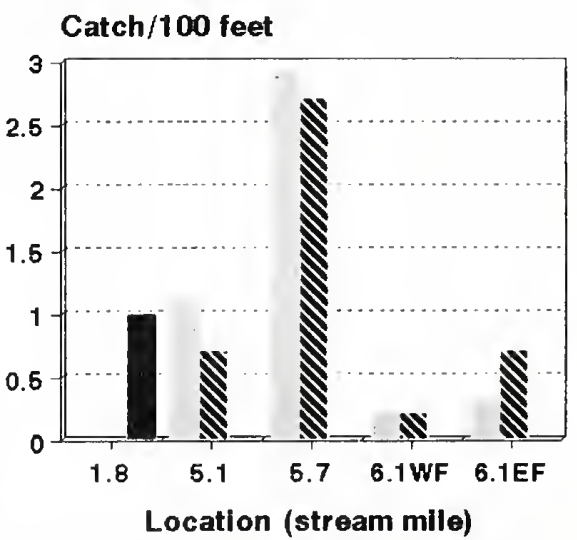
(Appendix H).

Figure 28. CPUE for fish $>4.0$ inches at 5 locations of Willow Creek below Lincoln. 


\section{Fish Populations}

We sampled fish populations at five locations in the Willow Creek drainage. The surveys recorded only brown trout in lower sample and mixed westslope cutthroat trout and brook trout populations in the headwaters (Figure 28). Sampling at the lower Willow Creek section produced low numbers of brown trout. The three mainstem surveys recorded densities increasing in the upstream direction with the total CPUE (all fish> 4.0 ") increasing from 1.0 to 1.9 to 5.6 at stream mile $1.8,5.1$ and 5.7 respectively. The CPUE was much lower in the two tributaries compared to the mainstem below the tributaries. Analysis of the westslope cutthroat genetic samples $(\mathrm{n}=24)$ showed no introgression.

\section{Upper Willow Creek}

Upper Willow Creek is a $2^{\text {nd }}$ order tributary, entering the upper Blackfoot River at river mile 123.9. Stream gradient ranges from $440 \%$ mile between stream mile 7.0 and 6.0 and 40 '/mile between stream mile 1.0 and the mouth. Willow Creek flows primarily through Sieben Ranch property and mixed private ownership (Figure 29).

We sampled Willow Creek was sampled at five locations. At the two lower survey locations, the riparian shrub community appeared healthy. The riparian overstory in the $3^{\text {rd }}$ survey locations was sparsely populated with conifers, which limited LWD recruitment to the stream. At this site, streambank erosion was severe. Substrate was composed mainly of gravel and sand with elevated levels of sediment. Excessive livestock use appears to be the primary cause. At the $4^{\text {th }}$ survey, the riparian health improved and streambanks showed limited impacts.

The riparian area at the $5^{\text {th }}$ survey had a riparian overstory of conifers with a shrub and sedge understory and stable streambanks.

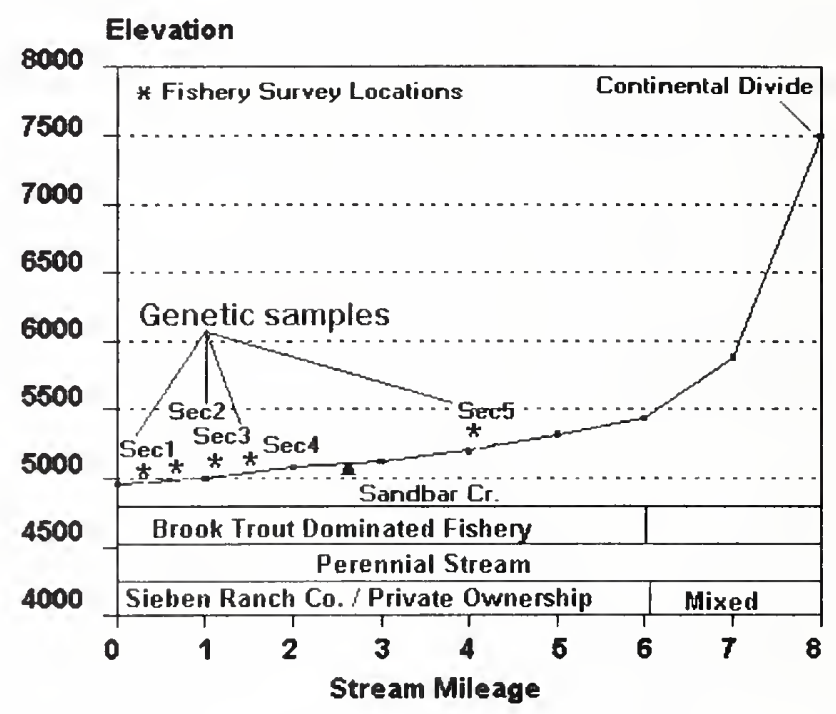

Figure 29. Longitudinal profile for Willow Creek upstream of Lincoln.

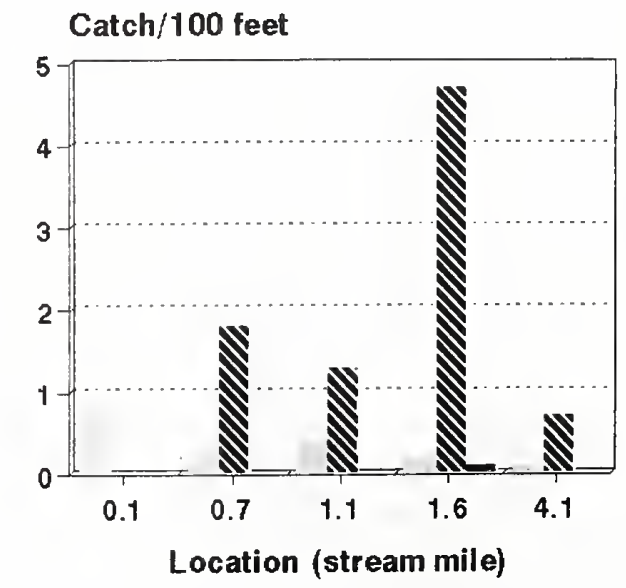

Cutthroat Trou

N Brook Trout

Brown Trout

Figure 30. CPUE for fish $>4.0$ " at 5 sites in upper Willow Creek 1999. 


\section{Fish Populations}

Westslope cutthroat trout were sampled at all sites in low densities. Densities (fish>4.0") decreased in the upstream direction from a CPUE of 0.8 at mile 0.1 to a CPUE of 0.1 at mile 4.1. Brook trout were the dominant species upstream of mile 0.7 (Figure 30). The $4^{\text {th }}$ survey produced one eleven-inch brown trout. Overall, we observed very low numbers of YOY. Because of the low number of westslope cutthroat trout sampled, only 14 genetic samples were collected. The results of genetic testing found no introgression with this small sample size.

\section{Part III: Fish Population and Habitat Monitoring on Restoration Streams}

Part III summarizes tributary restoration efforts, fish habitat evaluations and/or fish population monitoring on project streams or streams being considered for restoration activities (Figure 31). For most of these streams, detailed project and fisheries information can be found in three previous reports (Peters 1990, Pierce et al. 1997, Pierce and Schmetterling 1999)

\section{Bear Creek}

Restoration Objectives: restore habitat degraded by historical activities in the channel, restore fish passage and thermal refugia, improve recruitment of trout to the Blackfoot River.

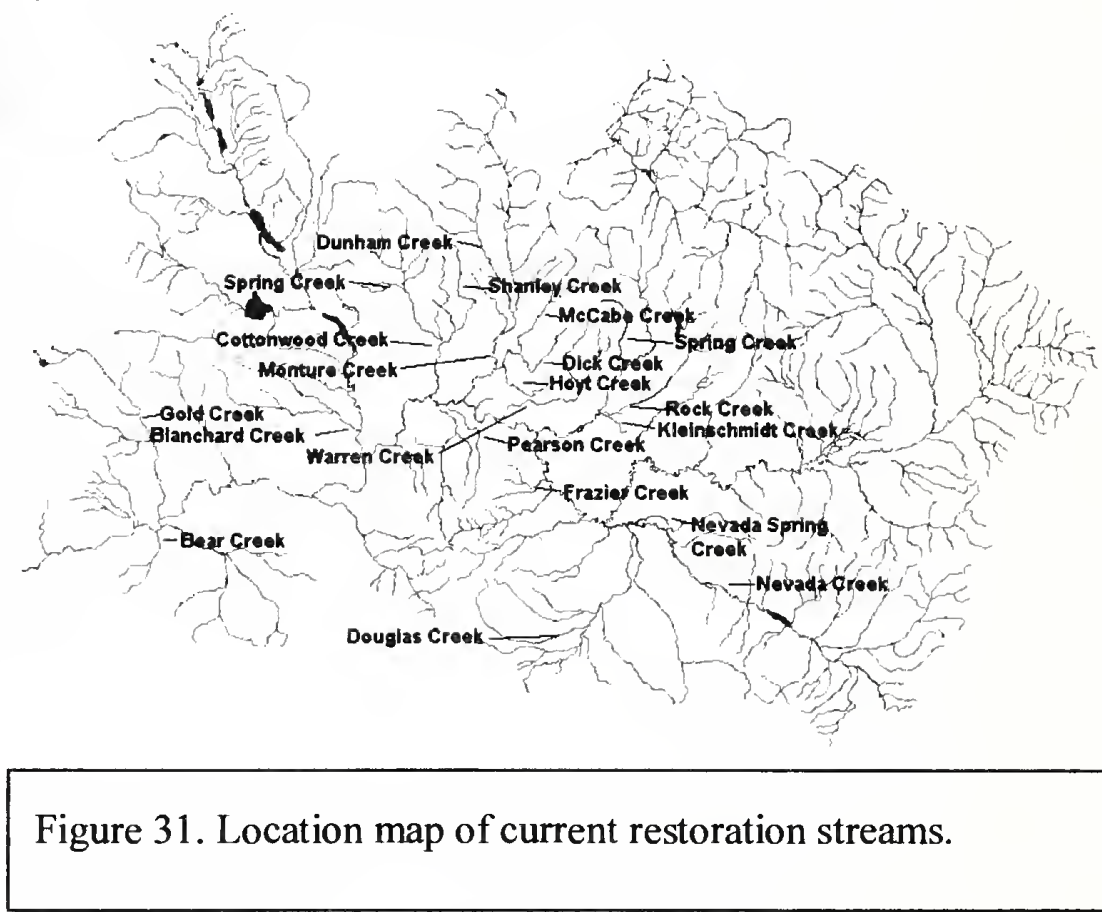

\section{Project Summary}

Bear Creek, a small 2nd order tributary of the lower Blackfoot River, flows six miles north to its mouth where it enters the Blackfoot River at river mile 12.2. The base flows is approximately $5 \mathrm{cfs}$. Bear Creek is one of the coldest streams entering the Black foot River (Appendix H). Bear Creek has a long history of land management activities resulting in degraded fish habitat. Impacts include loss of migration corridors, dewatering and simplification of fish habitat through poor riparian management. These impacts have resulted from poorly designed road crossings, road drainage problems, irrigation impacts, channelization of the stream, grazing and poor riparian timber harvest activities (Pierce et al.1997, Pierce and Schmetterling 1999).

Restoration activities began in the Bear Creek drainage in 1995 and continued through 1999. Restoration activities included: 1) upgrading culverts and addressing road drainage problems; 2) improving water control structures at irrigation diversions; 3) reconstructing 2,000' of channel and enhancing habitat complexity on an additional 
2,000 ' stream; 4) shrub plantings and the development of riparian grazing system which includes new offstream water developments for one mile of stream. Planned activities for the year 2000 include 1) placement of additional LWD in the channel area where reconstruction occurred, and 2) a weed control project in the area of reconstruction.

Fish Populations

Past alterations of Bear Creek combined with poor riparian management have resulted in a wide range of adverse impacts to salmonids and their habitats. Low numbers of non-native salmonids currently dominate the system. Bull trout are absent from the drainage although they were present historically (FWP, unpublished data). Westslope cutthroat trout densities are currently very low.

In 1998 prior to channel reconstruction, two fish population survey sections were established in Bear Creek: one upstream (reference) section (mile 1.5) not affected by projects; and a downstream section (mile 1.1) in the reconstructed

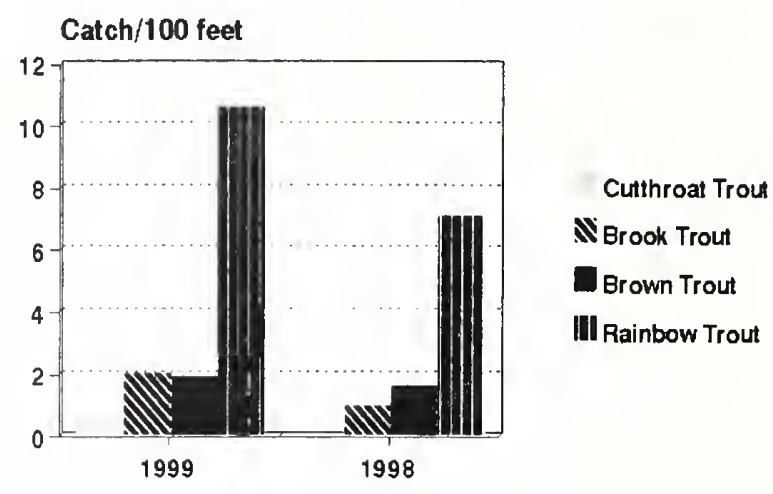

Location (stream mile)

Figure 32. CPUE (fish $>4.0$ ") at mile 1.1 in 1998 and 1999.

reach. In 1999, we established a survey section (mile 1.1) in the newly constructed channel. In 1999, total trout density (fish $>4.0$ ") was 17.7 fish/100' compared with 12.6 fish/100' in the old channel in 1998. Small increases in densities occurred for all species including rainbow trout, brown trout and brook trout. Two westslope cutthroat trout were also captured in the newly constructed channel, compared to zero in 1998 sample (Figure $32)$.

\section{Blanchard Creek}

Restoration objectives: improve access, spawning and rearing conditions for trout and improve recruitment of trout to the Blackfoot River.

\section{Project Summary}

Blanchard Creek is a spawning tributary for adult rainbow trout that reside in the Clearwater River and Blackfoot River. Blanchard Creek was historically dewatered in its lower one mile from irrigation, resulting in major salmonid declines in this reach. The irrigator began increasing flows in 1991. A water lease was implemented in 1993 in order to maintain a three cfs minimum instream flow during the irrigation season.

\section{Fish Populations}

Lower Blanchard Creek currently supports higher rainbow trout densities than historically due to the water leasing effort and related upgrades to irrigation diversions. In 1990 , YOY rainbow trout densities were estimated at $14.4 \pm 0.7$ trout $/ 100$ ' while age $1+$ rainbow trout were estimated at $5.6 \pm 2.2$ in the dewatered reach. In 1999, YOY densities were estimated at $61.7+6.0$ fish $/ 100$ feet. Age $1+$ rainbow trout density was 


\section{$11.2+1.9$ fish/100' (Figure 33).}

A thermograph near the mouth of Blanchard Creek showed that Blanchard Creek provide some cooling influence to the lower Clearwater River. However, temperatures were higher than downstream tributaries with the exception of Elk Creek (Appendix H).

\section{Cottonwood Creek}

Restoration objectives: improve degraded habitat, eliminate fish losses to irrigation ditches and restore migration corridors for native fish.

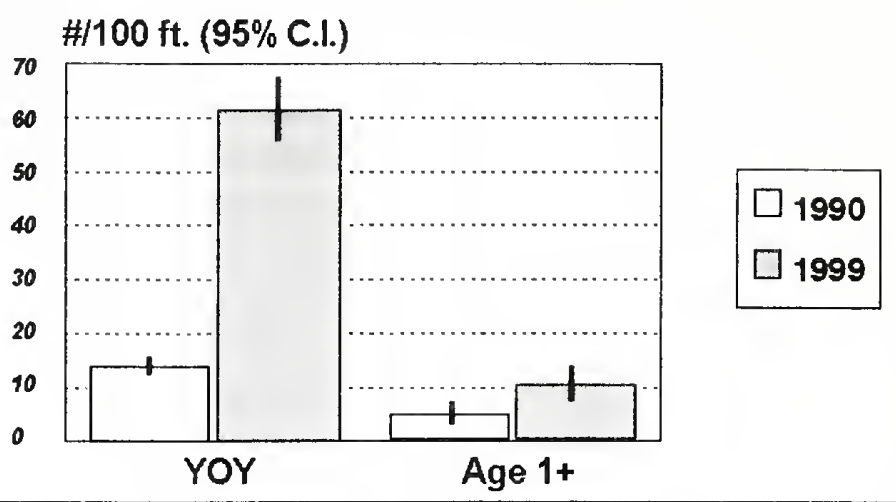

Figure 33. Estimated densities for rainbow trout in Blanchard Creek. 1990 and 1999.

\section{Project Summary}

Cottonwood Creek, a major $3^{\text {rd }}$ order tributary to the middle Blackfoot River, flows 11 miles south from a glacial valley through prairie pothole country to its mouth at river mile 43. Cottonwood Creek supports populations of bull trout, westslope cutthroat trout, rainbow trout, brown trout and brook trout. Rainbow trout inhabit the lower mile of stream while brook trout and brown trout dominate middle stream reaches. Westslope cutthroat trout and bull trout dominate the upper basin, but bull trout status is considered precarious.

Impacts to the fish and their habitats have occurred throughout the Cottonwood Creek drainage although several of the major problems have been addressed in the last several years. Completed improvement projects include water conservation measures and water leasing, upgrading irrigation diversions with fish ladders and fish screens and implementation of riparian grazing systems along Cottonwood Creek and Shanley Creek. Problems currently affecting the fish population include reduced riparian health, channel instability and habitat limitations in the middle reaches of Cottonwood Creek, poorly placed culverts in Spring Creek and the North Fork of Cottonwood Creek and high whirling disease infection levels in the lower reaches of Cottonwood Creek.

\section{Project monitoring}

Following implementation of the water lease, westslope cutthroat trout densities (fish $>4.0^{\prime \prime}$ ) at stream mile 12.0 increased from 2.9 fish $/ 100^{\prime}$ in 1997 to $6.8 \mathrm{fish} / 100^{\prime}$ in 1998. Fisheries-related investigations in the mid- to upper reaches of Cottonwood Creek in 1999 included: 1) assessing fish populations in an impacted tributary (see Spring Creek) which historically entered Cottonwood Creek in the area of bull trout reproduction; and 2) a fish habitat assessment in a reach of Cottonwood Creek affected by the lease. Both assessments represent initial efforts to identify habitat restoration opportunities in Cottonwood Creek.

In 1999, we surveyed fish habitat from the Woodworth Road crossing upstream for 6,944', and a 472' reference reach located upstream. A comparison between the two sites showed the reference reach to have higher habitat complexity with four times ( 4.2 
stems compared to $1.0 / 100^{\prime}$ ) the amount of active instream large woody debris. The downstream survey also recorded mean bankfull width of 24.3' and 26.9' for pools and riffles respectfully, compared to $19.4^{\prime}$ and $19.0^{\prime}$ in the reference reach.

A thermograph placed near the mouth of Cottonwood Creek recorded mean daily temperatures in the low to mid fifties. This provides some cooling to the Blackfoot River. These temperatures are considered ideal for the production of triactinomyxon (TAMS). Whirling disease studies report a high-grade infection in lower Cottonwood Creek although infection levels and T. tubifex densities decline in the upstream direction (Smith 1998, Pierce and Schmetterling 1999).

\section{Frazier Creek}

Restoration objective: improve long-term viability of a pure westslope cutthroat trout population isolated in the headwaters.

\section{Project Summary}

Frazier Creek is a disjunct 2nd order tributary to the middle Blackfoot River, entering at river mile 59.4. Frazier Creek has 3.6 miles of perennial stream, the lower 0.5 miles of which has been altered a several locations and currently has no fisheries value. The North Fork enters Frazier Creek at stream mile 1.0. It has 1.6 miles of perennial stream and fish passage barrier located at stream mile 0.3. Both the mainstem and North Fork provide water for intensive irrigation activities that include two instream reservoirs on the mainstem and three irrigation diversions. In fish-bearing water above the lower reservoir, fragmentation of stream reaches has occurred at two locations, including the upper reservoir and in the lower North Fork. Fragmentation resulted in 2.6 miles of stream above the upper reservoir, 0.7 miles above the lower reservoir and 1.7 miles above a fish passage barrier in the North Fork. For disjunct populations, a minimum of five miles of perennial stream is recommended to maintain long-term persistence and genetic variability (B. Shepard, personal communication)

Restoring connectivity to the river is not currently a consideration; however, options to 1) eliminate fragmentation in the headwaters, 2) reduce cutthroat trout entrainment, and 3) maintain the existing irrigation system are being explored.

\section{Fish Populations}

Frazier creek supports a pure population of resident westslope cutthroat trout with no other fish species present.

Both reservoirs provide holding areas and winter habitat for juvenile and adult westslope cutthroat trout while reproduction and rearing takes place in isolated stream reaches above each reservoir. In 1999, fish population surveys were completed in the North Fork at two locations: 1 ) immediately upstream of the confluence (mile 0.1 ); and 2 ) above a diversion barrier located at stream mile 0.3. At the downstream sample, stream flow was estimated at $0.3 \mathrm{cfs}$ compared to $0.7 \mathrm{cfs}$ at the upstream sampling location. At the lower section downstream of the fish barrier, CPUE for YOY was 17.2 compared with 4.0 above the fish passage barrier. CPUE for age I+ fish was 2.1 at the downstream site compared with 6.7 at the upstream sampling location. 


\section{Gold Creek}

Restoration Objectives: restore pool habitat and morphological complexity, restore thermal refugia for Blackfoot River native fish.

\section{Project Summary}

Gold Creek is the largest tributary to the lower Blackfoot River, entering at river mile 13.5. The harvest of riparian conifers combined with the actual "cleansing" of large woody debris from the channel reduced habitat complexity in the lower three miles of Gold Creek. Prior to 1996, pools accounted for less than $1 \%$ of the stream area in this section of stream. Low densities of age 1+ fish, including native fish, resulted from the habitat simplification. In 1996, we installed 66 habitat structures made of native material (rock and wood) that resulted in 61 new pools in the 3-mile section.

\section{Project Monitoring and Fish}

Population Surveys

Eight months after completion of the project an estimated 50-year flood event passed through the project area. Following this event, $85 \%$ of the structures remained intact although laterally confined reaches retained more pools than laterally extended reaches (Schmetterling and Pierce 1999). Following the 1997 flood

Depth ( \pm SD)

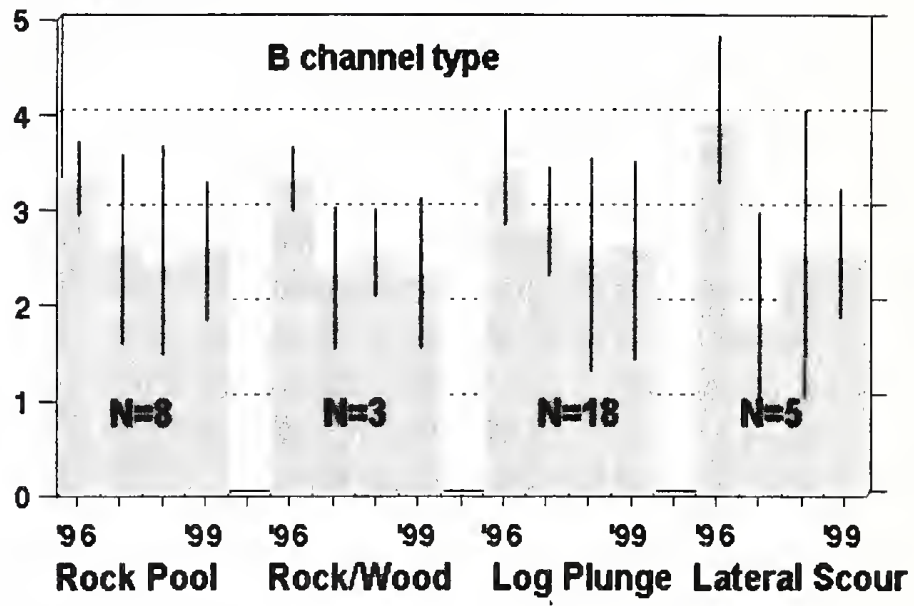

Figure 34. Pool depth (mean max \pm SD) changes in the $R$ channel sestion of Fonld reek 1096-1999

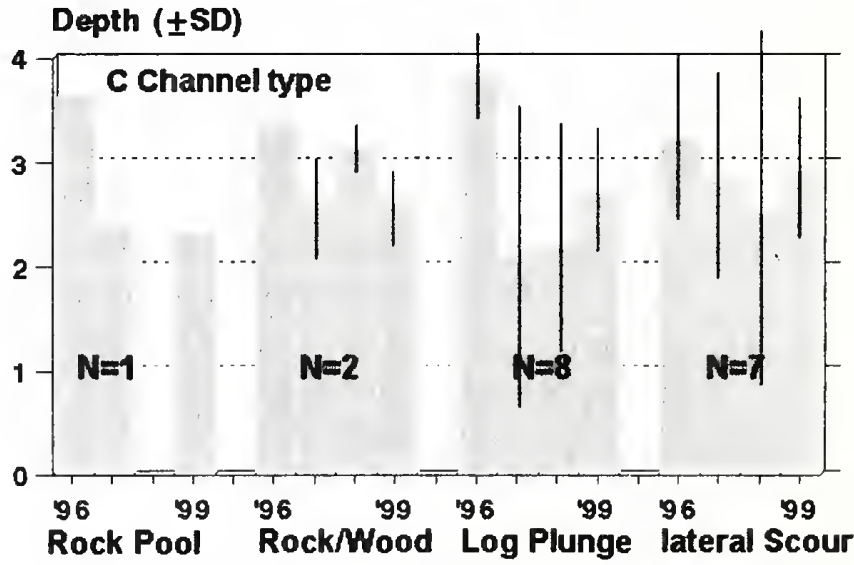

Figure 35. Pool depth (mean max. \pm SD) changes for the C Channel of Gold Creek 1996-1999. event, pool length increased and pool depth decreased. Subsequent pool measurements have shown generally stable pool depths but an interesting degree of year-to-year variation under more normal flow years (Figures 34 and 35).

In 1996 (prior to restoration), we established a fish population survey section in the treated area. Annual survey results from 1996-1999 show increasing fish numbers in the section (Figure 36). Telemetry studies have shown the project area receives seasonal use by migratory Blackfoot River bull trout in the fall and fluvial cutthroat trout use in the late spring (Pierce et al 1997, Schmetterling 2000). 
In 1999, stream temperature monitoring at mile 1.9 recorded mean August temperatures 6 degrees cooler than the ambient Blackfoot River recordings near Belmont Creek (Appendix H).

\section{Kleinschmidt Creek}

Restoration objectives: reduce whirling disease infection levels, restore stream channel morphology for all life stages of trout, increase recruitment of trout to the Blackfoot River, and restore thermal refugia and rearing areas for North Fork bull trout.

\section{Project Summary}

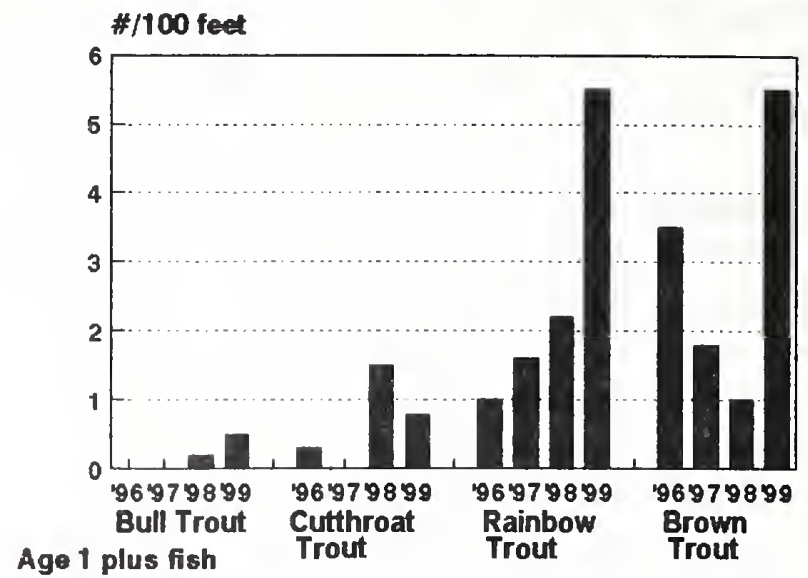

Kleinschmidt Creek, a spring fed tributary of the North Fork of the Blackfoot River, is degraded over most of its 1.5-mile length due to channelization, rock impoundments and a history of intensive riparian grazing. To date, 2,500' of stream has been restored and restoration is planned on an additional 5,300' of in 2000. Kleinschmidt Creek also supports a high level of whirling disease infection (See Results Part IV). This project will test the hypothesis that restoration of a degraded spring creek can moderate whirling disease infection levels.

\section{Project Monitoring and Fish Populations}

In 1999, three types of pre-restoration project data collection continued in Kleinschmidt creek. They are the continuation of 1) fish population surveys at two locations established in 1998, 2) stream temperature monitoring (Appendix H), and 3) a whirling disease sentinel cage study (Appendix I).

Fish population surveys continued at stream mile 0.5 and 0.8 . Both stations were established in 1998. The sample at mile 0.5 is located in a degraded, untreated reach. The 0.8 survey site is located in a channel section reconstructed in 1997. At the stream mile 0.5 -control section, the 1999 total trout density estimate (fish> 4.0 ") was not significantly different from 1998. At the 0.8 mile treatment section, fish $>4.0$ " appear to show

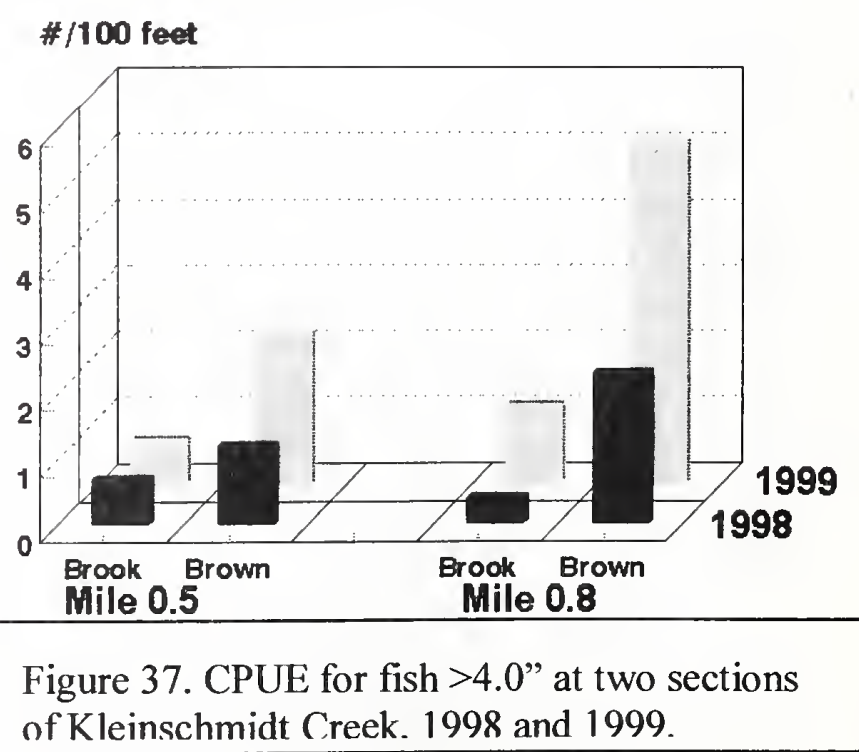
incremental increases (Figure 37). 
In 1999, a third fish population survey was completed in Kleinschmidt Creek a stream mile 1.1 (Appendix D). This survey documented one bull trout-the first to be documented in Kleinschmidt Creek in recent years.

Stream temperature monitoring continued throughout the summer and early fall in Kleinschmidt Creek. Temperatures averaged 2-3 degrees warmer than a partially restored adjacent spring creek. Currently, mean daily summertime temperatures in Kleinschmidt Creek are within the range of temperatures that coincide with high TAM production (Vincent 1999).

Whirling disease sentinel cage studies were completed in lower Kleinschmidt Creek in both 1998 and 1999. Between 1998 and 1999, whirling disease grade infection increased from 2.8 to 3.6. Most of the fish in the sample suffered grade 3 and 4 infection levels on the MacConnel/Baldwin Scale. According to Vincent (1999), the infection level is high enough to potentially cause population and reproductive damage.

\section{McCabe Creek}

Restoration objective: restore instream flows and habitat conditions for bull trout and westlslope cutthroat trout.

\section{Project Summary}

McCabe creek is located in the Monture Creek bull trout recovery area. McCabe Creek a cold basin-fed tributary to lower Dick Creek entering at stream mile 3.8. The upper portion of the stream is a steep mountain stream before entering knob-and-kettle topography in the lower basin. McCabe Creek has among the coldest recorded summer time stream temperatures recorded of any tributary in the Blackfoot Watershed, with mean daily temperatures ranging between 43-48 degrees (Pierce and Schmetterling 1999). In lower reaches, McCabe Creek enters a series of beaver-influenced wetland before entering Dick Creek.

McCabe Creek has a long history of channel alterations and land management activities that adversely affected the fish populations. These include a series of irrigation diversions, riparian grazing practices, physical alterations to the channel and poorly designed road crossings.

In 1999, a major restoration project was undertaken in McCabe Creek. The effort 1) consolidated four irrigation ditches into one pipeline and screened the intake; 2) helped convert to sprinkler irrigation; 3 ) restored habitat conditions including the placement of instream wood and shrub plantings along $1 / 2$ mile of stream; 4 ) made necessary riparian livestock management changes; and 5) improved a county road crossing.

Two major fisheries benefits of the project relate to increasing stream

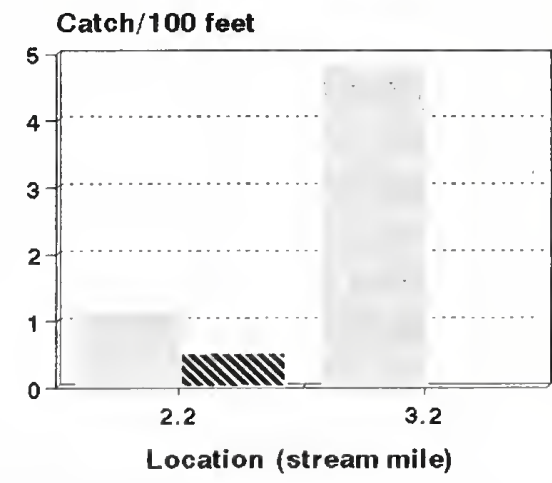

Figure 38. CPUE for fish $>4.0$ " at two sections of McCabe Creek 1999.
Cutthroat Trout

N Brook Trout 
flows by improving irrigation efficiencies, and eliminating westslope cutthroat trout losses to ditch system by installing a turbulent fountain fish screen at upper ditch intake. The pipeline project is expected to effectively double instream flows during base flow periods from approximately 4 to $8 \mathrm{cfs}$. When completed, the restoration effort is expected to help cool lower Dick Creek.

\section{Fish Populations}

McCabe creek is a westslope cutthroat trout dominated stream located in the Monture Creek bull trout recovery area. Westslope cutthroat trout are slightly hybridized with approximately $98 \%$ purity.

In 1999, fish population surveys were established at two locations (stream mile 2.3 and 3.2). The upstream sample was taken immediately above the upstream-most diversion in an area of quality and complex habitat. The lower sample was established immediately downstream of the lower-most diversion in an area of impaired habitat and reduced stream flows. Westslope cutthroat trout densities (fish $>4.0^{\prime \prime}$ ) declined from 7.0 fish $/ 100^{\prime}$ at the upstream site to $2.1 \mathrm{fish} / 100^{\prime}$ in the downstream location (Figure 38). Low numbers of brook trout were also found in the degraded section of stream (Appendix C, D).

\section{Monture Creek}

Restoration objectives: restore habitat for spawning and rearing bull trout and westslope cutthroat trout, improve staging areas and thermal refugia for fluvial bull trout, improve recruitment of bull trout and westslope cutthroat trout to the Blackfoot River.

\section{Project Summary}

Monture Creek, a large tributary to the middle Blackfoot River, is an important spawning and rearing tributary for fluvial bull trout and fluvial westslope cutthroat trout, with most of the reproduction and rearing taking place in the middle reaches of the basin. Rainbow trout and brown trout inhabit the lower portions of the drainage. Brook trout are found throughout the drainage.

The lower to middle portion of the drainage has a long history of riparian land use activities that have resulted in adverse impacts to native fish habitat. Many of these problems have been corrected through a decade of cooperative restoration activities (Pierce et al. 1997, Pierce and Schmetterling 1999). In 1999, completed projects on the mainstem included additional livestock management measures and limited habitat restoration in lower reaches. Tributary efforts included restoring the headwaters of Dick Creek to its original historical channel, riparian livestock management changes on Hoyt Creek, addressing habitat problems in McCabe Creek, continued fundraising and channel design for the Dunham Creek restoration effort.

\section{Fish Populations and other monitoring}

Monitoring efforts in 1999 included 1) bull trout redd counts, 2) a fish population survey in lower Monture Creek, 3) temperature monitoring at two locations in the mainstem and one in lower Dick Creek, 4) a whirling disease sentinel cage study in lower Monture Creek near the mouth.

Bull trout redd counts continued an upward trend in 1999 with a total of 74 Redd 
recorded in Monture Creek.

In 1999, a mark-recapture fish population survey section was established in lower

Monture Creek. The sample was divided into two sections: an upstream section which had received no restoration activities other than livestock management improvement and an adjoining downstream section which received livestock management improvements and habitat restoration through the instream placement of large woody debris. Separate finclips were used to identify fish for each section. Total trout densities (fish $>6.0^{\prime \prime}$ ) in the upstream control section were $60 \mathrm{fish} / 1,000$ " compared to 106 fish 1,000 ' in the downstream restored section. The combined densities of native fish (fish $>6.0$ ") were approximately three times higher in the restored section compared to unrestored section (Figure 39). Combined densities of non-native trout were slightly higher in the restored section compared to the upstream section. Figure 40 shows the electrofishing catch for each species for the restored and non-restored sections.

Two temperature monitoring stations were established in Monture Creek in 1999; one upstream of Dick Creek and one near the confluence of Monture Creek with the Blackfoot River. One additional thermograph, placed in the lower Dick Creek, recorded temperatures $>70$ degrees and averaged 8 degrees warmer than Monture Creek upstream of the Dick Creek Confluence. This warming is

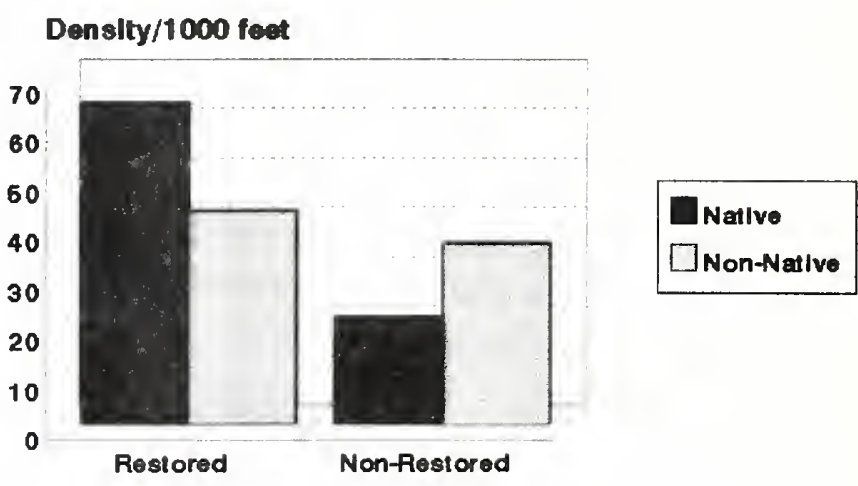

Natives $=$ Cutthroat and Bull Trout Non-Natlves=Rainbow and Brown Trout

Figure 39. Estimated densities (fish $>6.0$ ") for native and non-native salmonids in two sections of Monture Creek 1999.

largely of natural origin due to large wetlands that drain into lower Dick Creek. The lower Monture Creek thermograph recorded temperatures averaging 4 degrees higher in August than the Monture thermograph upstream of Dick Creek. Poor riparian health in lower Monture Creek may further contribute to warming (Fitzgerald 1997). 


\section{Pearson Creek}

Restoration objectives: restore the stream to its original channel, improve stream flows and access to historical spawning sites for fluvial westlslope cutthroat trout.

\section{Project Summary}

Pearson Creek is a small 2nd order tributary to the Chamberlain Creek with a base flow of approximately $1 \mathrm{cfs}$. Pearson Creek has a history of channel alterations, irrigation and riparian land management impacts in its lower 2 miles of channel. The Pearson Creek restoration effort includes conservation easements, water leasing, habitat restoration and improved riparian grazing management. Additional restoration planned activities include improving habitat complexity by placing instream woody debris and additional riparian livestock management measures.

\section{Project monitoring}

In 1998, fluvial westslope cutthroat trout were recorded migrating through the area affected by the water lease to an upstream spawning area (Schmetterling 2000). A 1999 fish population survey recorded YOY densities at $44.6 \pm 6.6 \mathrm{fish} / 100^{\prime}$ and age $1+$ fish densities at $10.9 \pm 4.4$ fish $/ 100^{\prime}$ immediately upstream of the water lease area.

\section{Rock Creek}

Restoration Objectives: restore migration corridors and restore natural stream morphology to improve spawning and rearing conditions for all fish using the system.

\section{Project Summary}

Rock Creek, a basin-fed stream over most of its length, also receives significant groundwater inflows between stream mile 1.2 and 1.6. Rock Creek has been degraded over most of its 8.2 mile length due a wide range of riparian management activities. Restoration of Rock Creek began in 1992. In 1999, an additional 2,507' of severely degraded and over-widened stream was reconstructed to Rosgen E4 geometry, bringing the total amount of restored stream to 5.5 miles. The restoration project also included placing instream woody debris and shrub plantings throughout the project area. The project was undertaken in the transition reach between surface and groundwater inflows.

\section{Project monitoring}

Three types of project monitoring were undertaken in the 1999 project area, including 1) stream temperature monitoring above and below the project, 2) duplication of a pre-project 1998 habitat survey (Koopal 1998), and 3) a continuation of fish population monitoring in the area of channel reconstruction.

The habitat survey showed that stream length increased $60 \%$ from $2,507^{\prime}$ preproject to $4,193^{\prime}$ post-project. Mean wetted width decreased from $22.5^{\prime}$ to $8.5^{\prime}$. Wetted channel surface area decreased from 1.3 to 0.8 acres. Instream woody increased from 0 to 9.2 stems $/ 100^{\circ}$. Ninety percent of the habitat units had active instream wood after project completion.

Stream temperatures taken in upper and lower portions of the project show significant cooling in the downstream direction. Maximum temperatures exceeded 78 degrees at the upper station but did not exceed 60 degrees at the lower station. At the 
downstream section, mean temperatures from July through September ranged from 48 to 51 degrees, compared to 50 and 61 degrees at the upstream monitoring site for the same period (Appendix H).

A fish population survey in the project site, four months after project completion, documented low numbers rainbow trout, brown trout and brook trout. Brown trout spawning was observed in the new channel in the fall of 1999

\title{
Spring Creek (Tributary to Cottonwood Creek)
}

Spring Creek-a primary tributary to upper Cottonwood Creek entered Cottonwood Creek in a reach of stream used for bull trout rearing and cutthroat trout reproduction until 1989. Spring creek was originally sampled in its lower reaches in 1989. At that time, the entire stream with an estimated base flow of $2-3 \mathrm{cfs}$ had recently been diverted. Since then, the entire flow of Spring Creek has been diverted on a year-around basis resulting in the loss of migration corridors and loss of spawning and rearing areas for native fish. The Natural Resource Conservation Service is currently at the early stages of developing a project to address landowner needs and allow instream flows and connectivity to be restored in lower Spring Creek.

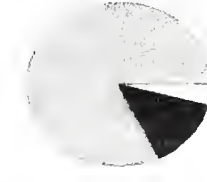

1989
7 Cutthroat

Bull

Brook

1999
Figure 41. Species composition for Spring Creek, 1989 and 1999.

\section{Fish populations}

In 1999, we resurveyed a fish population monitoring section established in 1989. These surveys recorded a shift from a primarily native fish community to a resident brook trout dominated assemblage (Figure 41). In 1999, the species composition Spring Creek was $11 \%$ westslope cutthroat trout and $89 \%$ brook trout, compared with $82 \%$ westslope cutthroat trout, $14 \%$ bull trout and $4 \%$ brook trout in 1989. In 1999, the CPUE of westslope cutthroat trout declined from 4.1 to 1.9 fish $/ 100$ '. Brook trout CPUE increased from 0.2 to $15.7 \mathrm{fish} / 100$ '

\section{Part IV Additional}

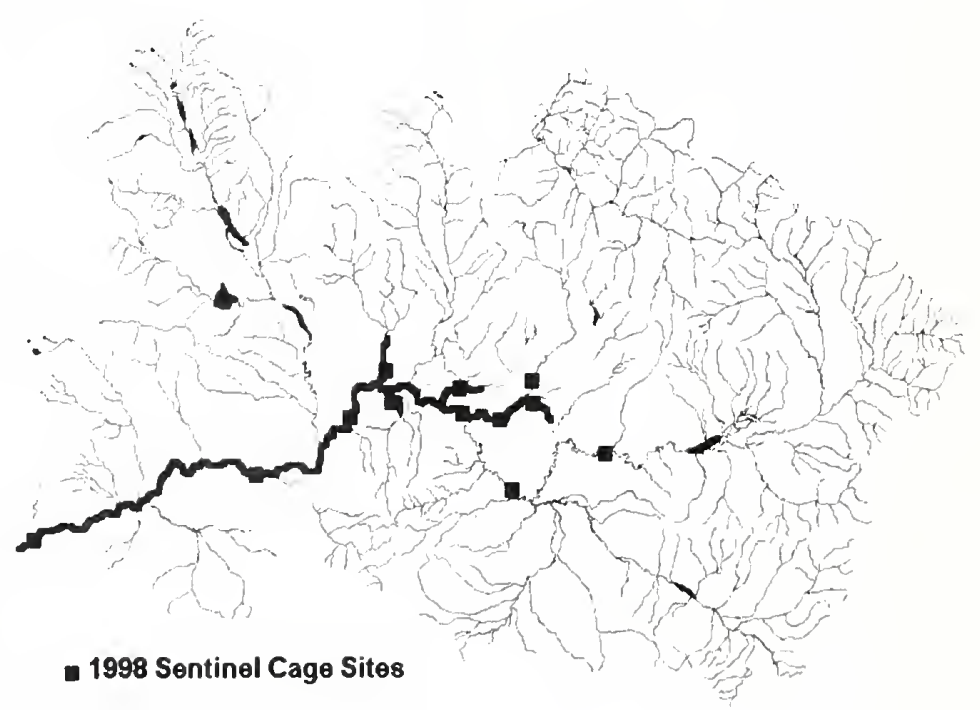
Aquatic Investigations

\author{
Whirling Disease \\ Investigations
}

Figure 42. Sentinel cage locations and known distribution of whirling disease for the Blackfoot Watershed 1999. 
Over the last several years, the exotic parasite Myxobolus cerebralis, which causes whirling disease, has been discovered in streams and river throughout western Montana including the Blackfoot River watershed. High-risk areas for contracting the disease include spring creeks, tailwater fisheries and degraded stream environments. Conversely, unimpacted mountain streams and rivers, warm water systems and lake outlets are listed as low risk areas (D. Gustufson, MSU, personal communication). From 1995 through 1997, wild fish were collected at 38 locations on 23 streams in the Blackfoot Watershed and tested for whirling disease. As of 1997, five tributaries and the Blackfoot River near Cottonwood Creek tested positive for the disease; the positive locations were generally concentrated in the central region of the watershed in or near groundwater-fed environments. The Clearwater drainage, several peripheral basin-fed streams and the Blackfoot River below the Clearwater River junction tested negative for the disease (Pierce and Schmetterling 1999).

In 1998, twelve cages were place in the Blackfoot River watershed with six in the mainstem Blackfoot River and six in tributaries (Figure 42, Table 1). In the up-river direction, Blackfoot River samples were located 1) near the mouth at Bonner, 2) below Elk Creek, 3) above the Clearwater River, 4) below the mouth of the North Fork, 5) below Nevada Creek at Raymond Bridge, and 6) near Arrastra Creek. Tributary samples included Chamberlain Creek, Cottonwood Creek, Warren Creek, the North Fork Blackfoot River above and below Kleinschmidt Creek and in lower Kleinschmidt Creek.

Results from the 1998 samples showed all four lower Blackfoot River stations tested positive for the first time. These sites recorded low-grade infections ranging from $0.21-1.10$. The two upper Blackfoot River samples tested negative for whirling disease. All sampled tributaries with the exception of the North Fork upstream of Kleinshcmidt Creek also tested positive for the disease (Figure 42). The tributaries which tested positive in 1998 had previously been identified as whirling disease positive with the exception of Chamberlain Creek which was "suspect" for the disease in 1997. For most tributary sites that tested positive, infection levels were below what is considered dangerous to the wild trout populations with the exceptions of Kleinschmidt Creek and Cottonwood Creek which support infection levels high enough to cause population problems through loss of recruitment (Vincent 2000).

At the time of the printing of this report, we have received results from nine of twenty 1999 Blackfoot River drainage cages. A comparision of these to the 1998 results showed whirling disease escalation in five of six duplicate locations. Increasing infections were found in Chamberlain Creek (grade 2.71), Kleinschmidt Creek (grade 3.56), Cottonwood Creek (4.72) and Warren Creek (2.1) and the Blackfoot River below Elk Creek (grade 0.52).

No population declines have yet been attributed to whirling disease; however, several stream reaches are now near or above lethal (grade 2.5) infection levels for vulnerable species (Vincent 2000). Known disease "hot spots" are localized at the lower elevations, the general distribution of the disease now closely corresponds to that of rainbow trout, a species highly vulnerable to the disease. The disease is also expanding into lower Chamberlain Creek, a primary fluvial westslope cutthroat trout spawning area.

A recent $t$. tubifex distribution study in Cottonwood Creek, found an inverse relationship between worm densities and elevation (Smith 1998). This relationship suggests that Blackfoot River native trout might escape widespread infection due to their 
Table 1. Whirling disease test results for 12 sites in the Blackfoot River drainage, 1998 and 1999.

\begin{tabular}{|c|c|c|c|c|c|}
\hline Stream & $\begin{array}{l}\text { River } \\
\text { Mile }\end{array}$ & Date & \#/fish & $\begin{array}{l}\text { Percent } \\
\text { infected }\end{array}$ & $\begin{array}{l}\text { Mean Grade } \\
\text { Infection }\end{array}$ \\
\hline \multicolumn{6}{|l|}{ Blackfoot River } \\
\hline & 0.5 & $7 / 1-11 / 98$ & 36 & 14 & 0.22 \\
\hline & 27 & $7 / 1-11 / 98$ & 41 & 15 & 0.21 \\
\hline & 27 & $7 / 14-24 / 99$ & & 42 & 0.52 \\
\hline & & $7 / 1-11 / 98$ & 20 & 52 & 1.10 \\
\hline & & $7-14-24 / 99$ & & 17 & 0.22 \\
\hline & 53 & $7 / 1-11 / 98$ & 41 & 15 & 0.25 \\
\hline & 67 & $7 / 1-11 / 98$ & 27 & 0 & 0 \\
\hline & $\underline{90}$ & $7 / 1-11 / 98$ & 50 & 0 & $\underline{0}$ \\
\hline \multicolumn{6}{|c|}{ Tributaries } \\
\hline North Fork of the & 7 & $7 / 1-11 / 98$ & 43 & 0 & 0 \\
\hline Blackfoot River & 2 & $7 / 1-11 / 98$ & 50 & 12 & 0.14 \\
\hline Kleinschmidt & 0.5 & $7 / 1-11 / 98$ & 48 & 90 & 2.83 \\
\hline Creek & 0.5 & $7 / 1-11 / 99$ & & 90 & 3.56 \\
\hline Chamberlain & 0.1 & $8 / 19-29$ & & 55 & 0.90 \\
\hline \multirow[t]{2}{*}{ Creek } & 1.0 & $7 / 1-11 / 98$ & 50 & 8 & 0.16 \\
\hline & 1.0 & $7 / 1-11 / 99$ & & 93 & 2.71 \\
\hline Chamberlain, E. F. & 0.1 & 8/19-29/99 & & 0 & 0 \\
\hline Chamberlain, W. F & 0.1 & 8/19-29/99 & & 0 & 0 \\
\hline \multirow[t]{2}{*}{ Cottonwood } & 1.0 & 7/1-11/98 & 50 & 94 & 3.66 \\
\hline & 1.0 & $7 / 1-11 / 99$ & & 98 & 4.72 \\
\hline \multirow[t]{2}{*}{ Warren } & 1.0 & $7 / 1-11 / 98$ & 47 & 19 & 0.21 \\
\hline & 1.0 & $7 / 1-11 / 99$ & & 84 & 2.10 \\
\hline
\end{tabular}

reliance on headwater tributaries for spawning and rearing.

Two ongoing Blackfoot River restoration strategies should help moderate future impacts of whirling disease. One strategy is restoring riparian health to make it less favorable for the worm host of myxobolus cerabralis. Reducing stream temperatures, reducing instream fine sediment and nutrient levels and restoring healthy invertebrate communities through continued riparian restoration efforts contribute to this strategy. This strategy is currently being undertaken on all whirling disease positive tributaries. The Kleinschmidt Creek restoration project will help test the hypothesis that whirling disease can be reduced in a degraded spring creek by restoring stream health and reducing water temperature. The second strategy involves restoring habitat for native trout with life histories that should prevent exposure of young fish at an age when they are most vulnerable to the disease.

\section{Temperature Studies}

The temperature study included nine Blackfoot River sampling locations, including five long-term sampling locations, plus 32 sampling sites on 29 tributaries (Figure 43). Of these 29 tributaries, 19 are direct tributaries to the Blackfoot River. For these 19 tributaries, temperature sensors were placed near their confluences with the river. 
This following section includes a brief summary of water temperatures for the Blackfoot River and 19 direct tributaries for August 1999. August coincides with unfavorable warming of river temperatures and movement of some native fish to areas of thermal refuge (Swanberg 1996. Pierce et al. 1997). The summary is further organized by river reach; reaches correspond with longterm river temperature monitoring locations. Graphs of all raw data plus all additional monthly summary statistics for all locations are located in Appendix $\mathrm{H}$.

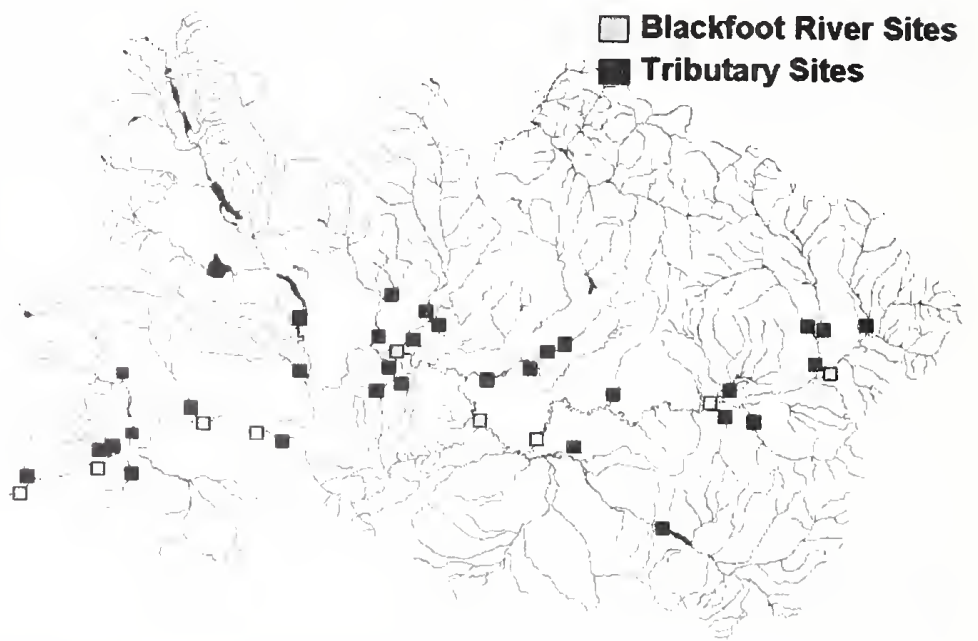

Figure 43. Stream temperature recording stations in the Blackfoot Watershed 1999.

\section{Blackfoot River Temperatures for August 1999}

In the mid- to lower Blackfoot River, warming during summer period increases to unfavorable levels for some Blackfoot River salmonids including bull trout (Swanberg 1996). In 1999, August temperatures for the Blackfoot River showed an upward trend in the downstream direction with mean daily temperatures increasing 10 degrees between Lincoln and Milltown Dam (Figure 44).

Mean temperatures in a 38 mile section of river from Lincoln (river mile 107) to the Cutoff Bridge (river mile 69)

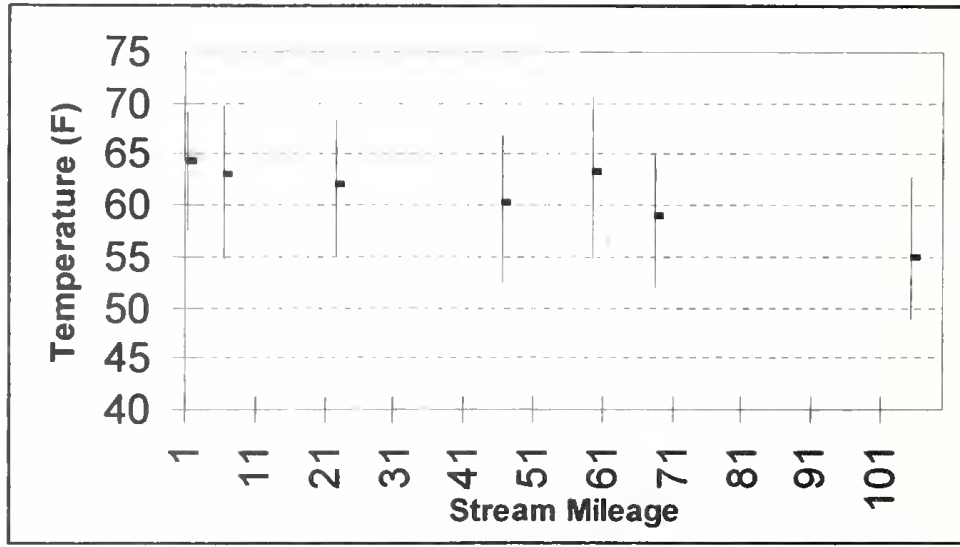

Figure 44. Mean, maximum and minimum temperatures for 7 Blackfoot River locations for August 1999. increased 4 degrees (54.9 to 59 degrees). Mean river temperatures increased an additional 4.3 degrees in a 9-mile section of river between the Cutoff Bridge and Raymond Bridge (River mile 60), bringing mean August temperatures to 63.3 degrees. From Raymond Bridge fifteen miles downstream to Scotty Brown Bridge (river mile 45), mean temperatures decreased 3.1 degrees to 60.2 degrees due to the cooling influence of the North Fork Blackfoot River. From Scotty Brown Bridge 24 miles downstream to Belmont Creek (river mile 22) mean ambient river temperature increased 2 degrees. 
Between Belmont Creek and Wisherd Bridge mean August temperatures increased 1.0 degrees. From Wisherd Bridge to the mouth of the Blackfoot River (river mile 0.0) increased an additional 1.3 degree to a mean of 64.4 degrees.

Maximum river temperatures for August ranged from a low of 62.7 at Lincoln to 70.8 degrees at Raymond Bridge. Maximum stream temperatures for the Cutoff Bridge, Raymond Bridge and Scotty Brown Bridge sections were 65, 70.8 and 67 degrees, respectfully. Maximum temperatures in the five lower river stations below Raymond Bridge were all in the upper 60's (Figure 44).

\section{Tributary Temperatures for August 1999}

Tributaries exhibited a wide range of thermal properties. For August 1999, temperatures for tributary sampling sites showed a slight increasing trend in temperatures in the downstream direction between Alice Creek (river mile 122.8) to Elk Creek (river mile 28.7). Interestingly, tributaries to the lower Blackfoot River downstream of Elk Creek showed the opposite trend of decreasing temperatures in the downstream direction (Figure 45).

Above the Blackfoot River monitoring site at river mile 107 , we recorded temperatures for Alice Creek, the Landers Fork and Poorman Creek. These three tributaries all had maximum stream $\mathrm{t}$ emperatures 2 to 5 degrees cooler than the mainstem monitoring site at mile 107. Two additional

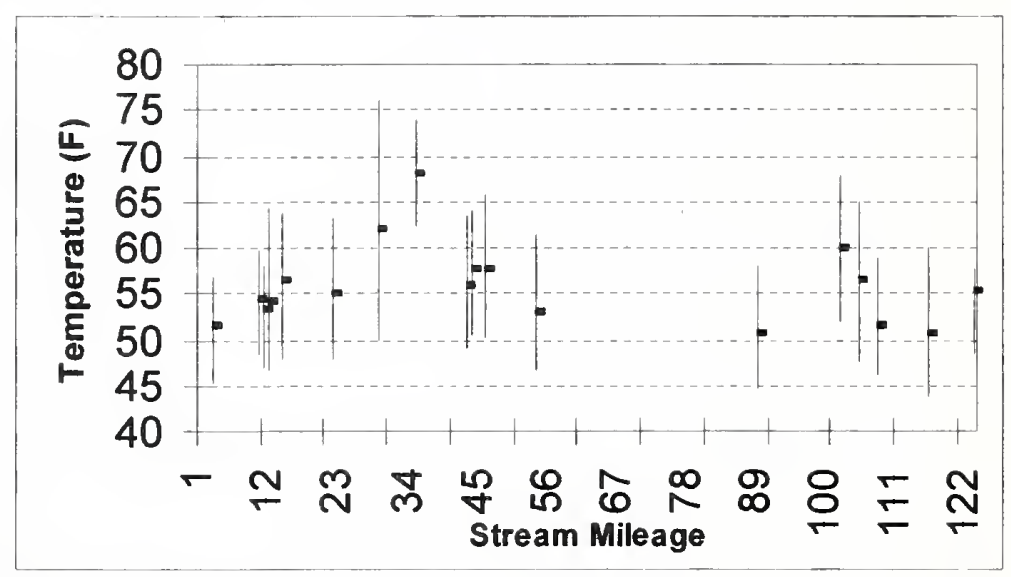

Figure 45. Mean, maximum and minimum stream temperatures for 19 tributaries to the Blackfoot River, August 1999.

stream temperature sensors were placed in the Landers Fork drainage; one in the Landers Fork above the mouth of Copper Creek and one in Copper Creek near its junction with the Landers Fork. The Landers Fork upstream of Copper Creek averaged 7 degrees warmer than the Landers Fork near the mouth. Mean August temperatures for Copper Creek was 9 degrees cooler than the upper Landers Fork station. Copper Creek further recorded the coolest summer time temperature of all 32 tributary monitoring sites in the Blackfoot Basin during the 1999 study.

Between the Lincoln and Cutoff Bridge Blackfoot River monitoring stations, we recorded water temperatures for Willow, Beaver and Arrastra Creeks. Willow Creek, the upper-most station in this section, had the warmest stream temperatures averaging 5 degrees warmer than the Blackfoot River monitoring station near Lincoln. Arrastra Creek, the lower-most station in the section, had the coolest stream temperatures, averaging 8 degrees less than the Blackfoot River Cutoff Bridge station.

In 1999, no tributary temperature data were collected in the mouth area of Nevada Creek located between river monitoring stations at river mile 69 and 60 . However, two temperature sensors were placed in the Nevada watershed, one below Nevada Reservoir 
and one in the Lower portion of Nevada Spring Creek (Appendix H). In past temperature studies, Nevada Creek has consistently contributed to river warming (Pierce and Peters 1990. Pierce and al. 1997).

Between the Raymond Bridge Section and the Scotty Brown Bridge mainstem monitoring stations, temperature data on both the North Fork Blackfoot River and Monture Creek were collected. For the North Fork, mean temperature was 10 degrees cooler than the Raymond Bridge section, while Monture Creek temperature averaged 6 degrees cooler than the Raymond bridge section. Additional water temperature sensors were placed in upstream reaches of both North Fork and Monture Creek drainages (Appendix H).

Between the Scotty Brown Bridge and Belmont Creek monitoring stations, temperatures were recorded at four tributaries. They are Chamberlain Creek, Cottonwood Creek, the Clearwater River (below Salmon Lake) and Elk Creek. The two upper tributaries, Chamberlain Creek and Cottonwood Creek, exhibited stream temperatures 2 to 4 degrees cooler than ambient river temperature at Scotty Brown Bridge monitoring station. The Clearwater River averaged 5 degrees warmer than the Blackfoot River at Belmont Creek and mean Elk Creek temperatures were comparable with ambient river temperatures. Both the Clearwater River and Elk Creek had the two highest recorded maximum stream temperatures of all monitored tributaries that directly enter the Blackfoot River; both exceeded 70 degrees in August.

From Belmont Creek to the mouth of the Black foot River, stream temperatures for six tributary confluence areas were monitored. In the downstream direction, they are Belmont Creek, Gold Creek, Bear Creek, East Twin Creek, West Twin Creek and Johnson Creek. A temperature thermograph placed in Union Creek malfunctioned. All 6 tributaries where sensors functioned properly recorded mean temperatures 8 to 12 degrees cooler than ambient river temperatures. All streams recorded mean temperatures in the low to mid 50's, none of which exceeded 57 degrees. Johnson Creek, the lowermost tributary to the river, recorded the lowest temperatures of all direct tributaries to the Blackfoot River. The confluence area of Johnson Creek is a documented thermal refuge area for bull trout (Swanberg 1996). The five upstream tributaries also support juvenile summer bull trout use, indicating they function as thermal refugia during periods when the Blackfoot River warms.

\section{Westslope Cutthroat Trout Genetics}

Stocking of hatchery rainbow trout ceased in the upper Blackfoot River watershed in the 1970s with the adoption of the wild trout management philosophy. Subsequent inventory efforts beginning in the late 1980's have recorded no pure rainbow in any of the Upper Blackfoot River waters above the Nevada Creek confluence (Peters and Spoon 1989, Peters 1990, Pierce et al.1997

During the 1980s and 1990s, the U.S. Forest Service collected westslope cutthroat trout genetic samples from 24 streams throughout the upper Blackfoot Basin upstream of Nevada Creek, all of which recorded pure westslope cutthroat trout (Figure 46). Although these results suggest a regional pattern of genetically pure fish throughout this headwater area, most of the samples were taken high in tributaries and were small sample sizes (Appendix J).

In 1999, we collected genetic samples from 13 primary tributaries to the upper 
Blackfoot River and two locations on the upper Blackfoot River (Figure 46). Samples were usually collected at multiple locations and as low in the basin as possible. In a few tributaries, low numbers of suspected westslope cutthroat trout resulted in sample size of less than 25 fish. These stream are Alice Creek $(\mathrm{n}=2)$, Upper Willow Creek $(n=14)$, the Landers Fork $(\mathrm{n}=8)$ and Bartlett Creek $(\mathrm{n}=14)$. Samples showed no introgression in 10 of 13 sampled streams above Nevada Creek; they are Alice Creek $(\mathrm{n}=2)$, Upper Willow Creek ( $\mathrm{n}=14)$, Lower Willow Creek $(\mathrm{n}=27)$, Seven-up Pete Creek - Samples Prior to 1999

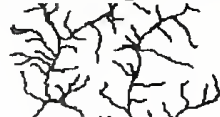

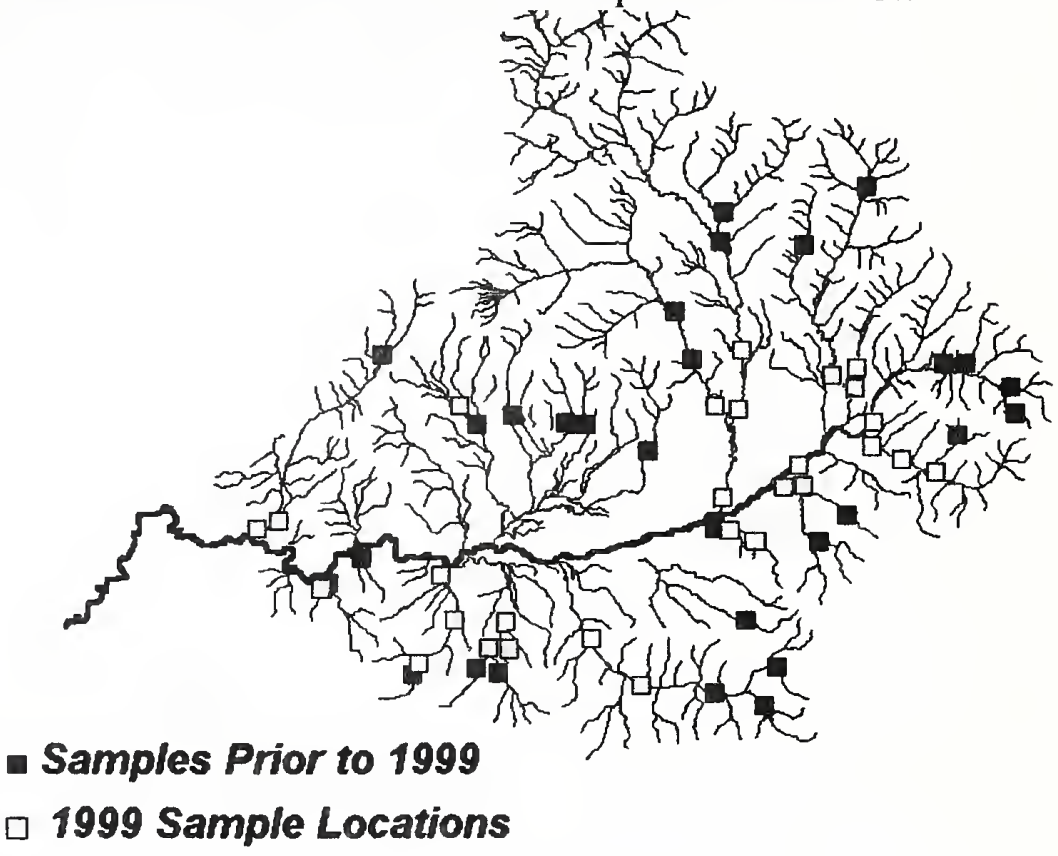
$(\mathrm{n}=25)$, Poorman Creek $(n=25)$, Sauerkraut Creek $(\mathrm{n}=25)$, Beaver Creek $(n=25)$, the Figure 46. Westslope cutthroat trout genetic sampling locations for the upper Blackfoot Watershed upstream of Nevada Creek.

Landers Fork $(n=8)$,

Copper Creek $(n=25)$ and Arrastra Creek $(n=25)$. Results of genetic samples with $<25$ fish should be used with caution due to lower statistical confidence resulting from small sample size (Appendix J)

Three tributaries above the mouth of Nevada Creek exhibited a low level of hybridization between westslope cutthroat trout and rainbow trout; Bartlett, Hogum and Moose Creek. The upper Blackfoot River sample was divided among two sampling sites (river mile 120.0 and 124.3). The downstream station $(\mathrm{n}=8)$ supported pure while the upper station $(n=15)$ detected a low level of rainbow trout introgression with westslope cutthroat trout. The four samples with hybrid fish recorded westslope cutthroat trout purity levels of $98.8 \%$ or higher.

No recent pure rainbow trout have been recorded in any upper river samples in recent years. Spence (1975) reported hatchery rainbow trout in proximity to some of these hybrid populations in the 1970s. There are currently no known rainbow trout in private fish ponds in the area.

\section{Riparian Health Inventories}

Riparian plant community structure and health are important elements of stream health, since plants serve many functions in river systems. These function include soil stabilization and stream bank protection from flooding and scouring, moderation of water temperatures, as well as contribution of wood for stream habitat. Loss of functional 
riparian plant communities can result in channel instability, increased erosion, higher sediment loads and warmer water, all of which have had adverse effects on aquatic ecosystems of the Blackfoot River watershed.

In 1999 , an

assessment of the

riparian health and plant communities was completed for 55 miles of the Black foot River between the Landers Fork to Cedar Meadows FAS (46 miles), and a nine mile section between Corrick River Bend and Gold Creek (Marler and Schmetterling 1999). The 1999 inventory supplements 58 miles of completed riparian health inventories (Figure 47). These earlier efforts

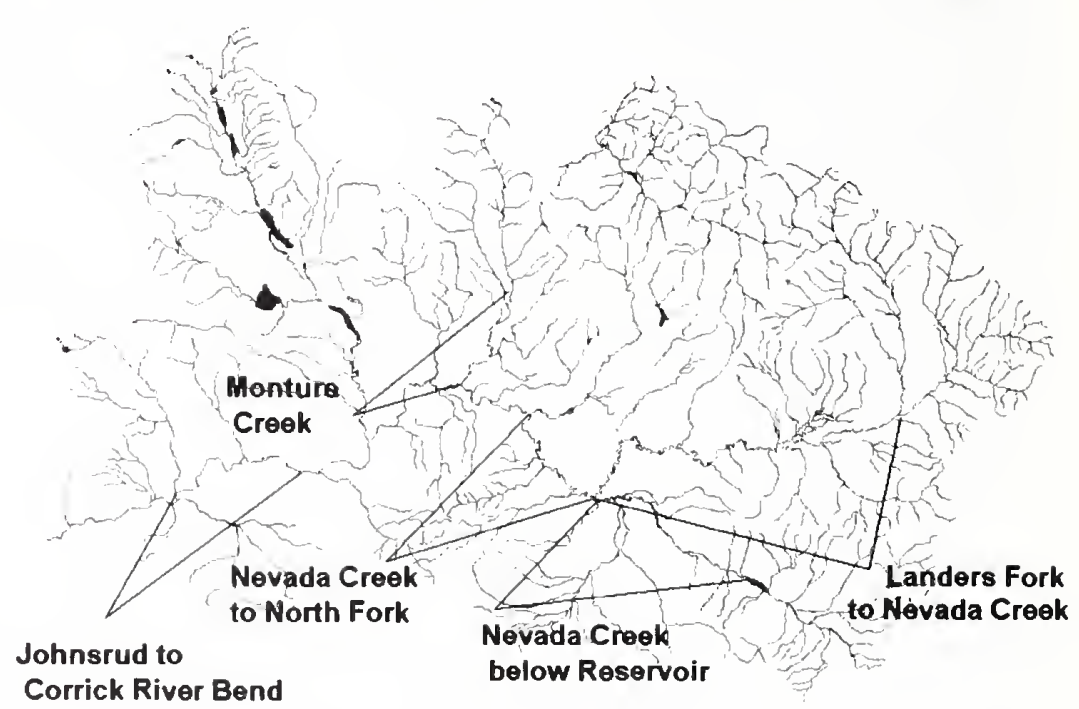

Figure 47. Location map of completed riparian health inventories through 1999.

include 1) 30 stream miles of Nevada Creek below the Reservoir, 2) 14 miles of the Blackfoot River between Nevada Creek and the North Fork confluence, and 3) 14 miles of lower Monture Creek (Fitzgerald 1996, 1997, Marler 1998).

From the Landers Fork downstream 46 miles to the Highway 141 Bridge, the riparian plant community consists of black cottonwood/shrub community types, including red osier dogwood and sandbar willow. The riparian area was rated as healthy on this reach of river although localized areas including BLM, USFS, State Trust Land and private lands were rated "at risk" due to invasive plants and anthropogenic erosion. Several localized channel manipulations were also recorded throughout the reach.

Between Highway 141 and Cedar Meadows FAS (11 river miles), the riparian corridor becomes more xeric with black cottonwood/juniper forest dominating the riparian corridor along with large aspen stand, patchy areas of willow and upland community types. Much of the riparian area in this reach was rated healthy. However health deteriorates in the down river direction upstream of Cedar Meadows FAS. Invasive weeds and grazing induced erosion contributed to the declining health trend (Marler and Schmetterling 1999).

The 1999 riparian health survey included the 9-mile section of lower Blackfoot River between Corrick River Bend and Johnsrud Park. The area received an overall healthy rating. However, eroded banks at areas of high recreational use, noxious weeds and localized erosion were noted.

In summary, the majority of surveyed riparian area in both upper and lower reaches of the Blackfoot River ranked as healthy. However, approximately 20 miles of middle river corridor between the Highway 141 Bridge and the North Fork confluence 
ranked at less than healthy. For Nevada Creek, $99 \%$ below the reservoir the riparian ranked at less than healthy (Fitzgerald 1996). The cumulative effects of degraded riparian areas contribute to warming of the Blackfoot River, reduced habitat quality and reduced Blackfoot River fish population densities. Many of the identified problems could be addressed through the development of riparian grazing systems. Improving riparian health and tributary function in this corridor should receive future priority. 


\section{Recommendations}

- Continue the effort by the FWS Partners of Fish and Wildlife Program and FWP on the Blackfoot Restoration Project. This effort relies on personnel with primary responsibilities of coordinating restoration and land management changes that are sensitive the fish and wildlife. This effort further requires increased fisheries personnel to cover basic fieldwork and other program needs. Support and additional efforts should be provided through watershed groups including the Big Blackfoot Chapter of Trout Unlimited, the North Powell Conservation District, the Blackfoot Challenge as well as other agencies and organizations.

-Complete a bull trout restoration and management plan for the Blackfoot River basin. All restoration objectives need to identify funding sources and personnel needs to accomplish the goal.

-Continue fish populations monitoring at the Johnsrud and Scotty Brown Bridge section of the Blackfoot River, and tributary restoration projects. Expand restoration and special study efforts into the upper Blackfoot River watershed including Poorman, Sauerkraut, Beaver, and lower Willow Creeks as field personnel and funding become available.

-Restore upstream fish passage at Milltown Dam and continue mitigation of Milltown dam impact in the lower Blackfoot River Watershed.

-Incorporate the Upper Clark Fork Natural Resource Damage settlement mitigation dollars into the Blackfoot Watershed native fish recovery program.

-Focus restoration and protection on migration corridors, spawning and rearing areas, and tributaries which have high proportion of their stream length in higher elevation and basin-fed stream with steeper gradients, which have been found to be less susceptible to T. tubifex and whirling disease.

-Continue to monitor the spread and impacts of whirling disease and the results of restoration on infection rates.

-Increase landscape protection efforts through conservation easements on critical fish and wildlife habitat in cooperation with the Montana Land Reliance, Nature Conservancy, US Fish and Wildlife Service and Montana Fish, Wildlife and Parks.

- The downward trend in the upper Blackfoot River westslope cutthroat trout population underscores the need for a thorough and timely cleanup of the Mike Horse mine and adjacent areas. Assess possible mining impacts in the Seven-up Pete, Sauerkraut, Poorman and Hogum Creeks and pursue remedial activities as necessary.

-Adopt a conservative approach to recreational planning in native fish recovery areas. These include the lower mainstem Blackfoot River below the confluence of the North Fork, Monture Creek and North Fork downstream of the North Fork Falls.

-Develop an effective fish identification program. 


\section{Acknowledgements}

Many agencies, organizations and individuals contributed to the content of this report. Above all, the Big Blackfoot Chapter of Trout Unlimited and Chutney Foundation deserve thanks for funding our seasonal fisheries technician position. This field help made the upper river data collections, project monitoring and much of the restoration work possible. The Fish and Habitat Committee of the BBCTU deserves further credit for reviewing and administering projects, addressing "millenium" culvert issues, resolving social conflicts, assisting in project maintenance and for sponsoring of the Rosgen training sessions. The North Powell Conservation District deserves credit for securing funding and providing guidance for the Nevada Creek water quality improvement project. We thank Greg Neudecker with the USFWS Partners for Fish and Wildlife Program for continued long-term support of the native fisheries initiative.

Regional FWP fisheries staff included contributions of Don Peters, David Schmetterling, Ladd Knotek and Jason Anderson. Glen Phillips and Mark Lere and the Future Fisheries Committee supported the effort though funding, administration and environmental permitting. Other key agency cooperators include the NRCS for their contributions in the Nevada Creek watershed and McCabe Creek project; the BLM for funding whirling disease and riparian health evaluations; the USFS for their efforts in the Monture Creek watershed; and MDT for funding the Kleinshmidt Creek project. Montana Power Company and Plum Creek Timber Company supported several restoration projects. We also thank the interns, high school teachers and students, consultants, contractors and all the landowners that cooperated on restoration projects and allowed us access to streams during the 1999 season. Finally, the comments of Don, Dave and Ladd at the regional fisheries office improved the quality of this report. 


\section{Literature Cited}

Bohneman, M., and D. A. Schmetterling. 2000. 1999 Blackfoot River creel survey, Montana Fish, Wildlife and Parks. Missoula, Montana.

Bureau of Land Management, Montana Riparian and Wetland Association. 1994. Montana BLM/MRWA Health Inventory (without Pflankuck) Ripaina Wetland (Lotic Weland) Form.

Coffin, D.L. and K.R. Wilke 1971. Water resources of the upper Blackfoot valley westcentral Montana. Water Resources Division, Montana Department of Natural Resource Conservation, Helena, Montana.

Hillman T. W. and D.W. Chapman. 1996. Assessment of fish populations in the upper Black foot River basin. A report to the Seven-up Pete Joint Venture. BioAnalysts Boise Idaho.

Fitzgerald, G. 1996. Inventory and analysis of riparian vegetation along lower Nevada Creek. A report to the Montana Fish, Wildlife and Parks, Missoula, Montana

Fitzgerald, G. 1997. Analysis and inventory of riparian vegetation along Nevada Creek and Monture Creek, using ADAR imagery. MS Thesis, University of Montana, Missoula, Montana.

Fredenberg, F. 1992. Evaluation of electrofishing-induced spinal injuries resulting from field electrofishing surveys in Montana. Montana Department of Fish, Wildlife and Parks, Bozeman, Montana

Kerans, B.L., M.M. Gangloff, and E. R. Vincent. 1999. Spatial relations between whirling disease severity and tibuficids. Proceedings of the Fifth Annual Whirling Disease Symposium, Research and Management Perspectives, Missoula, MT. Whirling Disease Foundation, Bozeman, Montana.

Ingman, G, L., M.A. Kerr and D.L. McGuire 1990. Water quality investigations in the Blackfoot River drainage, Montana. Department of Health and Environmental Services, Helena, Montana.

Koopal, M. 1998. Stream habitat analysis of selected tributaries to the Blackfoot River, 1998. Report prepared for the Montana Fish, Wildlife and Parks, Missoula, Montana.

Liknes, G. A. 1984. The present status and distribution of the westslope cutthroat trout (Salmon Clarki lewisi) east and west of the continental divide in Montana. Report to the Montana Department of Fish, Wildlife and Parks, Helena, Montana.

Liknes, G. A. and P. J. Graham. 1998. Westslope cutthroat trout in Montana: life history, status and management. Pages 53-60 in R.E. Gresswell, editor. Status and management 
of cutthroat trout: American Fisheries Society, Symposium 4, Bethesda, Maryland.

Marler, M. 1998. Riparian vegetation and health on the Blackfoot River between Nevada Creek and the North Fork confluence. Report prepared for the North Powell Conservation District and Montana Fish, Wildlife and Parks, Missoula, Montana.

Marler, M.J., and D A. Schmetterling. 1999. 1999 Riparian health \& inventory of selected reaches of the Blackfoot River. Final report to the BLM Garnet Resource Area and Montana Fish, Wildlife and Parks, Missoula, Montana.

McGuire, D. 1989. Blackfoot River aquatic macroinvertebrate survey. Prepared for the Montana Water Quality Bureau and Oakbrook Chapter of Trout Unlimited.

McGuire, D. 1991. Aquatic macroinvertebrate survey of the Blackfoot River, Montana, August, 1988 and 1989. Prepared for the Montana Department of Health and Environmental Sciences Water Quality Bureau, Helena, Montana.

McIntyre, J. D., and B. E. Reiman, 1995. Westslope cutthroat trout. Pages 1-15 in M. K. Young, editor. Conservation assessment for inland cutthroat trout. U. S. Forest Service General Technical Report. RM-256.

McMahon, T. E and 9 co-authors. 1999. Life history variation in rainbow trout in relation to whirling disease infection risk. Proceedings of the Fifth Annual Whirling Disease Symposium, Research and Management Perspectives, Missoula, MT. Whirling Disease Foundation, Bozeman, Montana.

Menges, J. 1997. Investigation of temporal changes of heavy metal concentration in sediments and water of the Blackfoot River, Montana. Masters of Science thesis, University of Montana. Missoula, Montana

Montana Fish, Wildlife and Parks. 1991, 1997. Statewide Fishing Pressure Estimates. Bozeman, Montana.

Moore, J. N., S. N, Louma and D. Peters 1991. Downstream effects of mine effluent on an intermontane riparian system. Canadian Journal of Fisheries and Aquatic Sciences. 48:222-232.

Peters, D. 1985. Current status of bull trout in the headwaters of the Clark Fork River, Montana. Page 37 in D. D. MacDonald, editor, Proceedings of the Flathead River basin bull trout biology and population dynamics modeling Information exchange Fisheries Branch, Brithish Columbia Ministry of Environmental. Cranbrook, British Columbia.

Peters, D. and R. Spoon. 1989. Preliminary fisheries inventory of the Big Blackfoot River. Montana Department of Fish, Wildlife and Parks, Missoula, Montana.

Peters, D. 1990. Inventory of fishery resources in the Blackfoot River and major 
tributaries to the Blackfoot River. Montana Department of Fish, Wildlife and Parks, Missoula, Montana.

Pierce R. and D. Peters, 1990. Aquatic investigations in the middle Blackfoot River, Nevada Creek and Nevada Spring Creek corridors, Montana Department of Fish, Wildlife and Parks, Missoula.

Pierce, $R, 1991$. A stream habitat and fisheries analysis for six tributaries to the Blackfoot River. Montana Department of Fish, Wildlife and Parks, Missoula, Montana.

Pierce, R., D. Peters and T. Swanberg. 1997. Blackfoot River restoration progress report. Montana Fish Wildlife and Parks, Missoula, Montana.

Pierce, R., and D. Schmetterling. 1999. Blackfoot River restoration project monitoring and progress report 1997-1998. Montana Fish, Wildlife and Parks, Missoula, Montana.

Ricker, W.E. 1975. Computation and interpretation of biological statistics of fish populations. Bulletin of the Fisheries Research Board of Canada, Bulletin 191. Ottawa Canada.

Rosgen, D. 1996. Applied Fluvial Geomorphology. Wildland Hydrology, Pagosa Springs Colorado.

Schmetterling D. and M. Long. 1999. Montana anglers inability to identify bull trout and other salmonids. Fisheries Vol. 24 No. 7, pp. 24-27.

Schmetterling D. A, and R. W. Pierce. 1999. Success of instream habitat structures after a 50-year flood in Gold Creek, Montana. Restoration Ecology 7(4), pp. 369-375.

Schmetterling, D. A. 2000. Seasonal movement of fluvial westslope cutthroat trout in the Blackfoot drainage. Montana. Montana Fish, Wildlife and Parks, Missoula, Montana.

Smith. L., 1998. Study on the distribution and abundance of Tubifex tubifex within Cottonwood Creek in the Blackfoot Drainage. MS Thesis, University of Missoula, Missoula, Montana.

Spence, L. 1975. Upper Blackfoot River Study: a preliminary inventory of aquatic and wildlife resources. Montana Department of Fish and Game Environmental and Information Division in Cooperation with the Anaconda Company.

Spence, L. 1997. Effects of the June, 1975 Mike Horse Mine tailing dam failure on water quality and aquatic resources of the upper Blackfoot River, Montana. Montana Fish, Wildlife and Parks, Helena, Montana.

Swanberg, T. R. 1996. The movement and habitat use of fluvial bull trout in the upper Clark Fork drainage. MS Thesis, University of Montana, Missoula, Montana. 
Swanberg, T. and L. Burns. 1997. Movement and habitat use of radioed tagged bull trout in the upper Blackfoot River drainage, Special report Region 2 Fisheries. Montana Fish, Wildlife and Parks, Missoula, Montana.

Vincent, R. 2000. Whirling Disease Report 1997-98. Montana Fish, Wildlife and Parks. Project 3860. Helena, Montana.

Vincent, R. 1999. How the relationship between water temperature and the intensity of Myxobolus cerebralis infections in rainbow trout can be used in management solutions. Proceedings of the Fifth Annual Whirling Disease Symposium, Research and Management Perspective, Missoula, MT Whirling Disease Foundation, Bozeman, Montana.

Workman, D., and D. Peters. 1996. 1994 Blackfoot River User Survey. Montana Department of Fish, Wildlife and Parks, Missoula, Montana. 


\section{Appendix}

Exhibit A: Summary of catch statistics for upper Blackfoot River Samples.

Exhibit B: Mark and recapture estimates in the Blackfoot River drainage, 1999.

Exhibit C: Summary of two pass population estimates for tributaries, 1999.

Exhibit D: Summary of catch and size statistics for tributaries, 1999.

Exhibit E: Table of restoration stream and activities through 1999.

Exhibit F: Table of potential restoration projects in the Blackfoot Drainage.

Exhibit G: Table of restoration streams and cooperators.

Exhibit H: Summary of water temperature monitoring in the Blackfoot Drainage, 1999.

Exhibit I: Whirling disease sampling results for 1998 and 1999.

Exhibit J: Westslope cutthroat trout genetic sampling results. 


\section{Appendix A}

Catch statistics for in five electrofishing sections of the Blackfoot River 1971-1999. Data prior to 1999 from Spence (1975) and Peters and Spoon (1989).

\begin{tabular}{|c|c|c|c|}
\hline $\begin{array}{ll}\text { Section } & \text { Length (ft.) } \\
\text { Pop's Place } & \end{array}$ & Species & \# in sample & Size Range \\
\hline \multirow{4}{*}{ Aug-Sept. '71 3486} & CT & 228 & $1.8-9.8$ \\
\hline & EB & 141 & $2.2-10.4$ \\
\hline & LNS & 2 & $5.7-6.7$ \\
\hline & Sculpin & 6 & -- \\
\hline \multirow[t]{4}{*}{ Aug-Sept. ' 88 1,816 } & CT & 32 & $1.5-8.4$ \\
\hline & EB & 304 & $1.7-8.0$ \\
\hline & LNS & 23 & $5.0-8.2$ \\
\hline & Sculpin & 29 & $2.4-4.1$ \\
\hline \multirow[t]{5}{*}{ Aug-Sept. ' 99 2,000 } & $\mathrm{CT}$ & 1 & 2.9 \\
\hline & $\mathrm{EB}$ & 90 & $2.4-10.1$ \\
\hline & LNS & 6 & $3.0-7.8$ \\
\hline & Dace & 1 & 5.1 \\
\hline & Sculpins & Present & \\
\hline \multicolumn{4}{|l|}{ Flesher Section } \\
\hline \multirow[t]{6}{*}{ Aug-Sept. ' 732,455} & CT & 185 & $1.5-10.9$ \\
\hline & $\mathrm{EB}$ & 108 & $2.0-9.1$ \\
\hline & MWF & 10 & $2.7-3.3$ \\
\hline & LNS & 8 & $4.5-6.5$ \\
\hline & Sculpin & 43 & $1.2-4.3$ \\
\hline & DV & Not Present & \\
\hline \multirow[t]{6}{*}{ Sept-Oct. ' $75 \quad 2,455$} & CT & 54 & $3.2-8.0$ \\
\hline & EB & 37 & $3.0-10.5$ \\
\hline & MWF & Not Present & \\
\hline & FSU & Not Present & \\
\hline & Sculpin & & \\
\hline & DV & Not Present & \\
\hline \multirow[t]{6}{*}{ Aug-Sept. ' 88 2,455 } & $\mathrm{CT}$ & 42 & $1.5-11.6$ \\
\hline & EB & 37 & $2.3-10.4$ \\
\hline & MWF & Not Present & \\
\hline & FSU & 7 & $1.5-6.5$ \\
\hline & Scuplin & \multicolumn{2}{|c|}{ Very Numerous } \\
\hline & DV & 1 & 8.8 \\
\hline \multirow[t]{2}{*}{ Sept.'99 } & CT & 34 & $4.2-10.1$ \\
\hline & EB & 54 & $2.7-9.2$ \\
\hline
\end{tabular}




\begin{tabular}{|c|c|c|c|c|}
\hline \multicolumn{2}{|c|}{ Section Length (ft.) } & Species & \# in sample & Size Range \\
\hline \multicolumn{5}{|c|}{ Flesher Section (cont.) } \\
\hline & & $\begin{array}{l}\text { LL } \\
\text { Sculpin }\end{array}$ & $\begin{array}{l}1 \\
\text { Present }\end{array}$ & 10.1 \\
\hline \multicolumn{5}{|c|}{ Hogum Section } \\
\hline \multirow{9}{*}{\multicolumn{2}{|c|}{ Aug-Sept. ' 72 4,100 }} & CT & 131 & $1.7-13.5$ \\
\hline & & EB & 74 & $2.7-9.9$ \\
\hline & & $\mathrm{RB}(\mathrm{H})^{* *}$ & 3 & $9.4-10.6$ \\
\hline & & LL & 1 & 6.5 \\
\hline & & DV & 7 & $6.5-13.6$ \\
\hline & & MWF & 31 & $2.7-13.5$ \\
\hline & & $\mathrm{CSu}$ & 5 & $5.3-11.6$ \\
\hline & & Dace & 19 & $2.5-5.6$ \\
\hline & & Sculpin & 422 & $1.1-4.8$ \\
\hline \multirow{9}{*}{ Sept. ' 73} & 4,100 & CT & 87 & $1.7-13.6$ \\
\hline & & EB & 84 & $2.6-8.1$ \\
\hline & & $\mathrm{RB}(\mathrm{H})^{* *}$ & 18 & $10.8-12.3$ \\
\hline & & $\mathrm{LL}$ & Not Present & \\
\hline & & DV & 3 & $6.8-13.6$ \\
\hline & & MWF & 31 & $2.7-13.5$ \\
\hline & & LNS & 6 & $2.5-6.4$ \\
\hline & & Dace & 6 & $3.0-5.0$ \\
\hline & & Sculpin & Numerous & \\
\hline \multirow{9}{*}{\multicolumn{2}{|c|}{ Aug-Sept. ' 884,100}} & CT & 49 & $1.3-13.5$ \\
\hline & & EB & 42 & $2.3-6.0$ \\
\hline & & RB & Not Present & \\
\hline & & LL & Not Present & \\
\hline & & DV & Not Present & \\
\hline & & MWF & 58 & $2.6-16.4$ \\
\hline & & LNS & 6 & $4.0-10.7$ \\
\hline & & Dace & 20 & $1.4-5.2$ \\
\hline & & Sculpin & Numerous & \\
\hline \multirow[t]{10}{*}{ Sept. '99 } & 4,000 & $\mathrm{CT}$ & 24 & $5.8-15.6$ \\
\hline & & EB & 4 & $2.9-8.3$ \\
\hline & & $\mathrm{RB}$ & Not Present & \\
\hline & & LL & 16 & $2.9-22.6$ \\
\hline & & DV & 1 & 6.1 \\
\hline & & MWF & 18 & $10.7-15.8$ \\
\hline & & WS & 2 & $5.3-8.1$ \\
\hline & & LNS & Not Present & \\
\hline & & Dace & Not Present & \\
\hline & & Sculpin & Numerous & \\
\hline
\end{tabular}


Canyon Section

Aug-Sept. '71 10,725

Aug-Sept. ' 88 8,026

Aug-Sept.'99 5,422

Raymond Bridge Section

Sept. ' $88 \quad 5,808$

Aug-Sept. '99 5,745

CT
EB
DV

LL

MWF

$\mathrm{NSq}$

CT

EB

DV

LL

MWF

$\mathrm{NSq}$

CT

EB

DV

LL

MWF

LL

$\mathrm{RB}$

CT

DV

MWF

$\mathrm{CSu}$

NSq

Dace

Sculpin

LL

$\mathrm{RB}$

CT

DV

MWF

$\mathrm{CSu}$

$\mathrm{NSq}$

Dace

Sculpin

1

7.5

1

4

221

79

?

1

Not Present

1

133

Present

Present

12

Not Present

2

104

Present

8.5-15.4

6.5-15.9

3.1-19.6

12.8

3.0-19.2

7.2-7.8

2.4-18.3

2.3-16.6

15.1

32

3.2-17.8

7.2-13.9

9.5-13.7

4

Not Present

Present

Present

Present

Present

Present

35

7.6-19.3

7.1-16.3

9.4-14.4

8

Not Present

Present

Present

Present

Present

Present

** Hatchery raised to catchable size before stocking

$\mathrm{LL}=$ brown trout, $\mathrm{RB}=$ rainbow trout, $\mathrm{EB}=$ brook trout, $\mathrm{CT}=$-westrslope cutthroat trout, $\mathrm{DV}=$ bull trout, $\mathrm{MWF}=$ mountain whitefish, $\mathrm{CSu}=$ coarsescale sucker, $\mathrm{NSq}=$ northern squawfish 

Exhibit B. Mark-recapture population estimates in the Blackfoot River drainage, 1999.

\begin{tabular}{|c|c|c|c|c|c|c|c|c|c|c|c|c|}
\hline Stream & $\begin{array}{c}\text { River } \\
\text { Mile } \\
\text { Mid-point }\end{array}$ & $\begin{array}{c}\text { Location } \\
(T, R, S)\end{array}$ & Date Sampled & $\begin{array}{c}\text { Section } \\
\text { Length } \\
\text { (ft) }\end{array}$ & Species & $\begin{array}{c}\text { Size } \\
\text { Class } \\
\text { (in) }\end{array}$ & Marked & Captured & Recaptured & $\begin{array}{l}\text { Efficien } \\
\mathrm{Cy}(\mathrm{R} / \mathrm{C})\end{array}$ & $\begin{array}{c}\text { Total Estim } \\
\pm 958 \mathrm{CI} \\
\end{array}$ & $\begin{array}{c}\text { Estim/ } 1000^{\circ}+ \\
958 \mathrm{CI} \\
\end{array}$ \\
\hline Stream & $\begin{array}{c}\text { River } \\
\text { Mile } \\
\text { Mid-point } \\
\end{array}$ & $\begin{array}{c}\text { Location } \\
(T, R, S)\end{array}$ & Date Sampled & $\begin{array}{c}\text { Section } \\
\text { Length } \\
\text { (ft) }\end{array}$ & Species & $\begin{array}{c}\text { Size } \\
\text { C1ass } \\
\text { (in) }\end{array}$ & Marked & Captured & Recaptured & $\begin{array}{r}\text { Efficien } \\
\mathrm{Cy}(\mathrm{R} / \mathrm{C}) \\
\end{array}$ & $\begin{array}{c}\text { Tota1 Estim } \\
\pm 958 \mathrm{CI}\end{array}$ & $\begin{array}{c}\text { Estim/ } 1000^{\circ} \pm \\
958 \mathrm{CI}\end{array}$ \\
\hline BER below & 128.5 & $15 \mathrm{~N}, 667 \mathrm{~W}$ & 24-Aug-99 & 2000 & $\mathrm{~EB}$ & $2.0-3.9$ & 18 & 10 & 0 & & & \\
\hline \multirow[t]{3}{*}{ POP"s } & & 19824 & & & & $>4.0$ & 30 & 32 & 12 & 0.38 & $78 \pm 32$ & $38.8 \pm 15.8$ \\
\hline & & & & & $\mathrm{CT}$ & $1.5-2.9$ & 0 & 1 & 0 & & & \\
\hline & & & & & & $3.0-10.9$ & 0 & 0 & 0 & & & \\
\hline \multirow{4}{*}{$\begin{array}{l}\text { BER above } \\
\text { Flesher Pass } \\
\text { Rd. bridge }\end{array}$} & 124.3 & $15 \mathrm{~N}, 7 \mathrm{~W}, 35$ & 24-Aug-99 & 2457 & $\mathrm{CT}$ & $1.0-2.9$ & 0 & 0 & 0 & & & \\
\hline & & & & & & $>3.0$ & 15 & 17 & 7 & 0.41 & $35 \pm 17$ & $14.2 \pm 6.9$ \\
\hline & & & & & $\overline{E B}$ & $1.5-3.4$ & 6 & 3 & 0 & 0.00 & & \\
\hline & & & & & & $>3.5$ & 31 & 14 & 5 & 0.36 & $79 \pm 46$ & $32.2 \pm 18.5$ \\
\hline \multirow{4}{*}{$\begin{array}{l}\text { Blackfoot River } \\
\text { Raymond Bridge } \\
m=1,2 \quad R=3 \text { pass }\end{array}$} & & & 26-Aug-99 & 5745 & $\mathrm{LL}$ & $>6.0$ & 28 & 12 & 5 & 0.42 & $62 \pm 34$ & $10.8 \pm 5.9$ \\
\hline & & & & & $\mathrm{RB}$ & $>6.0$ & 4 & 5 & 1 & 0.20 & $14 \pm 13$ & $2.4 \pm 2.3$ \\
\hline & & & & & $\mathrm{CT}$ & $>6.0$ & 6 & 4 & 0 & 0.00 & & \\
\hline & & & & & All & $>6.0$ & 38 & 21 & 6 & 0.29 & $122 \pm 71$ & $21.2 \pm 12.1$ \\
\hline \multirow{6}{*}{$\begin{array}{l}\text { Blackfoot River } \\
\text { Canyon section } \\
M=1,2 \text { R=3 pass }\end{array}$} & & & 27-Aug-99 & 5422 & DV & $>6.0$ & 2 & 0 & 0 & & & \\
\hline & & & & & $\mathrm{CT}$ & $>6.0$ & 6 & 6 & 0 & 0.00 & & \\
\hline & & & & & LL & YOY & 4 & 1 & 0 & 0.00 & & \\
\hline & & & & & & Age1 & 12 & 7 & 1 & 0.14 & & \\
\hline & & & & & $>8.5^{\circ}$ & Age 2+ & 66 & 24 & 9 & 0.38 & $167 \pm 78$ & $30.7 \pm 14.1$ \\
\hline & & & & & ALL & $>6.0$ & 86 & 37 & 10 & 0.27 & $300 \pm 146$ & $55.2 \pm 26.3$ \\
\hline \multirow[t]{5}{*}{ Monture Creek } & & $15 \mathrm{~N}, 13 \mathrm{~W}, \mathrm{~S} 27$ & $22-J u 1-99$ & 5437 & $\mathrm{CT}$ & $>6.0$ & 19 & 20 & 5 & 0.25 & $69 \pm 44$ & $12.7 \pm 7.9$ \\
\hline & & & & & DV & $>6.0$ & 26 & 26 & 5 & 0.19 & $121 \pm 80$ & $22.2 \pm 14.5$ \\
\hline & & & & & $\mathrm{LL}$ & $>6.0$ & 39 & 23 & 11 & 0.48 & $79 \pm 31$ & $14.5 \pm 5.6$ \\
\hline & & & & & $\mathrm{RB}$ & $>6.0$ & 21 & 25 & 3 & 0.12 & $142 \pm 117$ & $26.1 \pm 21.1$ \\
\hline & & & & & All & $>6.0$ & 105 & 94 & 24 & 0.26 & $402 \pm 135$ & $73.9 \pm 24.4$ \\
\hline \multirow{7}{*}{$\begin{array}{l}\text { Monture Creek } \\
\text { Not restored } \\
\text { Upper Sect. }\end{array}$} & & $15 \mathrm{~N}, 13 \mathrm{~W}, \mathrm{~S} 27$ & 22-Ju1-99 & 3378 & $\mathrm{CT}$ & $>5.0$ & 6 & 7 & 1 & 0.14 & $27 \pm 27$ & $8.0 \pm 7.8$ \\
\hline & & & & & DV & $>6.0$ & 16 & 11 & 4 & 0.36 & $40 \pm 25$ & $11.8 \pm 7.2$ \\
\hline & & & & & natives & $>5.0$ & 22 & 18 & 5 & 0.28 & $72 \pm 45$ & $21.3 \pm 13.0$ \\
\hline & & & & & LL & $>6.0$ & 21 & 8 & 4 & 0.50 & $39 \pm 21$ & $11.4 \pm 6.1$ \\
\hline & & & & & $\mathrm{RB}$ & $>6.0$ & 9 & 15 & 1 & 0.07 & $79 \pm 85$ & $23.4 \pm 24.8$ \\
\hline & & & & & RBandLL & $>5.0$ & 30 & 23 & 5 & 0.22 & $123 \pm 81$ & $36.4 \pm 23.4$ \\
\hline & & & & & A11 & $>6.0$ & 52 & 41 & 10 & 0.24 & $201+100$ & $59.6 \pm 29$ \\
\hline \multirow{2}{*}{$\begin{array}{c}\text { Monture Creek } \\
\text { Restored }\end{array}$} & & $15 \mathrm{~N}, 13 \mathrm{~W}, \mathrm{S27}$ & $22-3 u 1-99$ & 2059 & $\mathrm{CT}$ & $>6.0$ & 13 & 13 & 4 & 0.31 & $38 \pm 25$ & $18.6 \pm 11.9$ \\
\hline & & & & & DV & $>6.0$ & 10 & 14 & 0 & 0.00 & & \\
\hline \multirow[t]{5}{*}{ lower sect. } & & & & & natives & $>6.0$ & 23 & 27 & 4 & 0.15 & $133 \pm 99$ & $64.8 \pm 47$ \\
\hline & & & & & LL & $>6.0$ & 18 & 15 & 6 & 0.40 & $42 \pm 23$ & $20.6 \pm 10.7$ \\
\hline & & & & & $\mathrm{RB}$ & $>6.0$ & 12 & 10 & 2 & 0.20 & $47 \pm 40$ & $22.7 \pm 18.9$ \\
\hline & & & & & RBandLL & $>6.0$ & 30 & 25 & 8 & 0.32 & $89 \pm 45$ & $43 \pm 21.6$ \\
\hline & & & & & Al1 & $>6.0$ & 53 & 52 & 12 & 0.23 & $219 \pm 102$ & $106.4 \pm 48.4$ \\
\hline
\end{tabular}




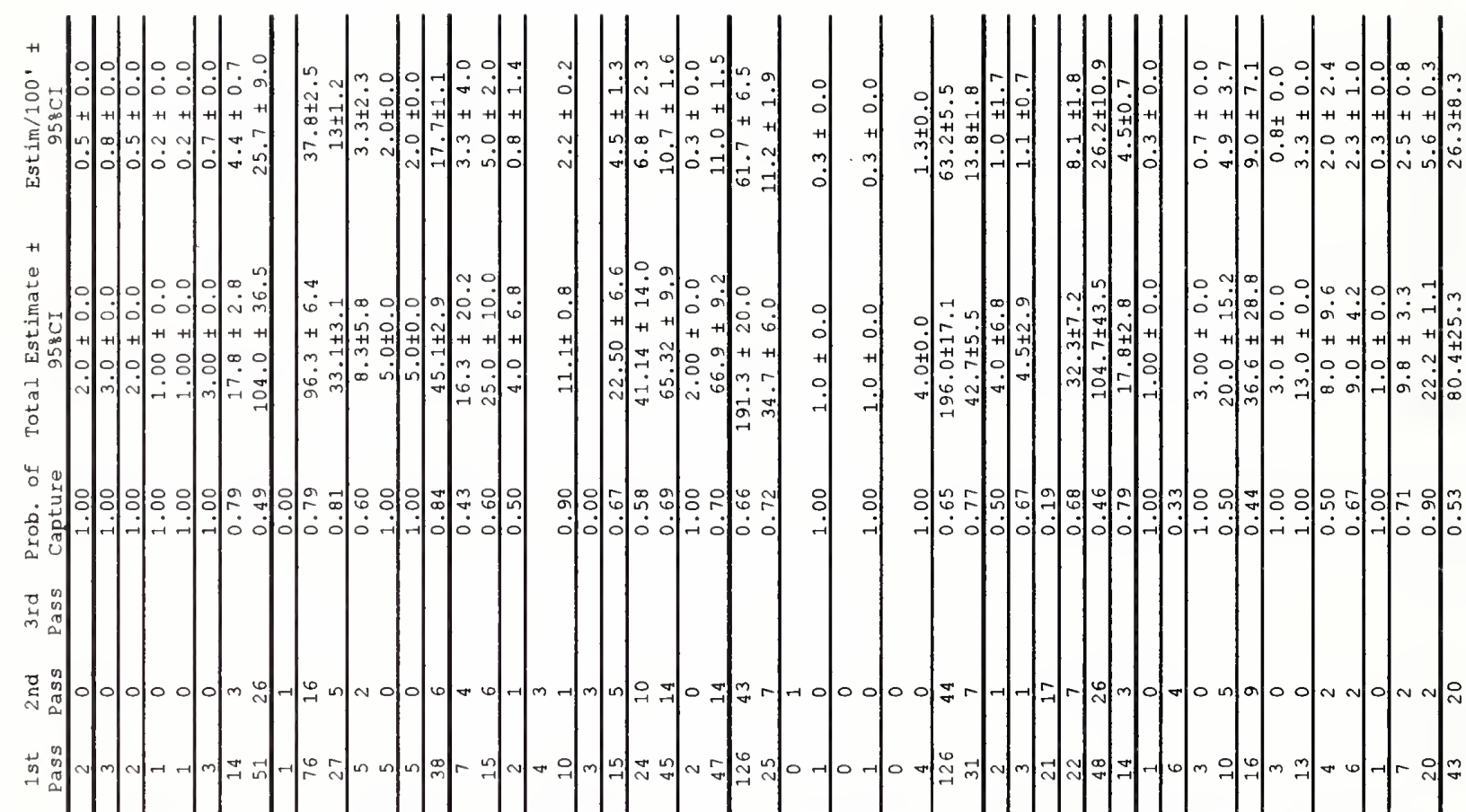
里告 कि

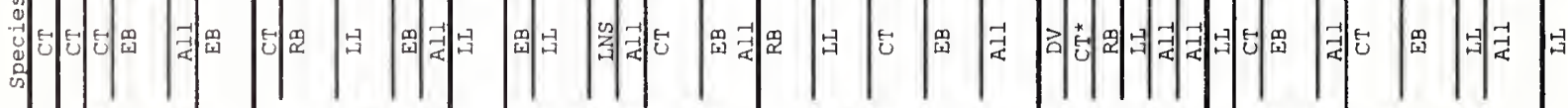
.

,

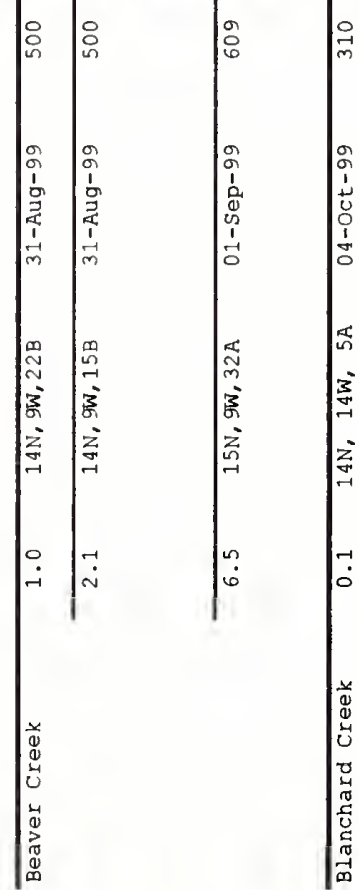

. 


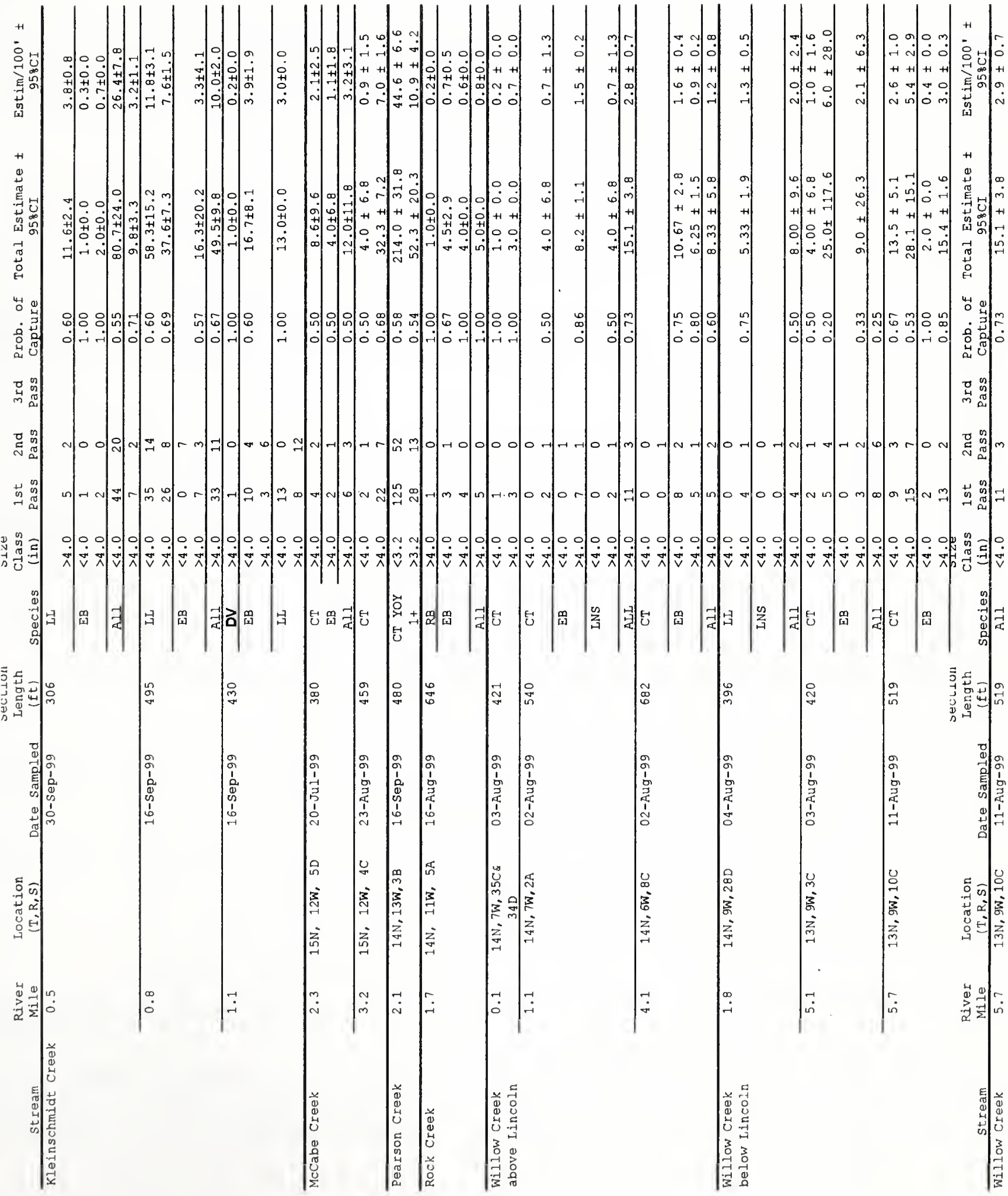




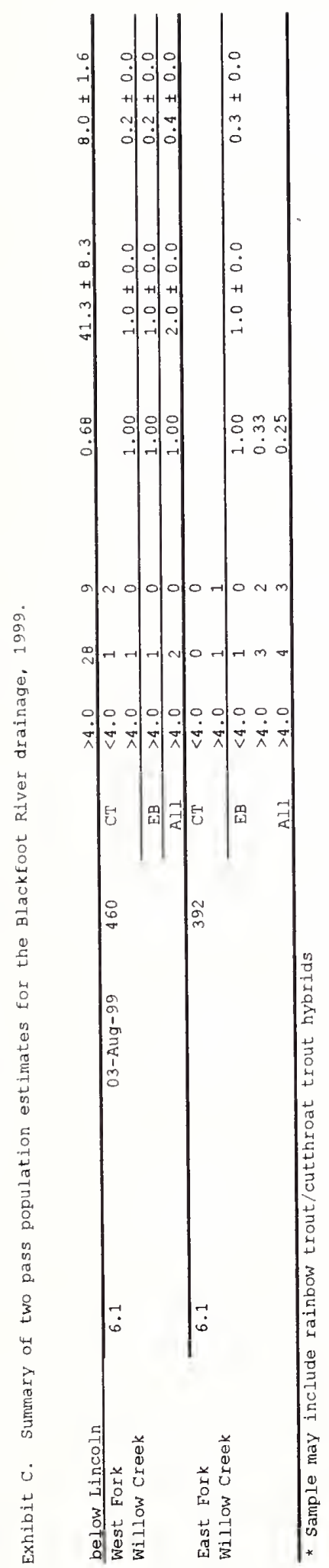




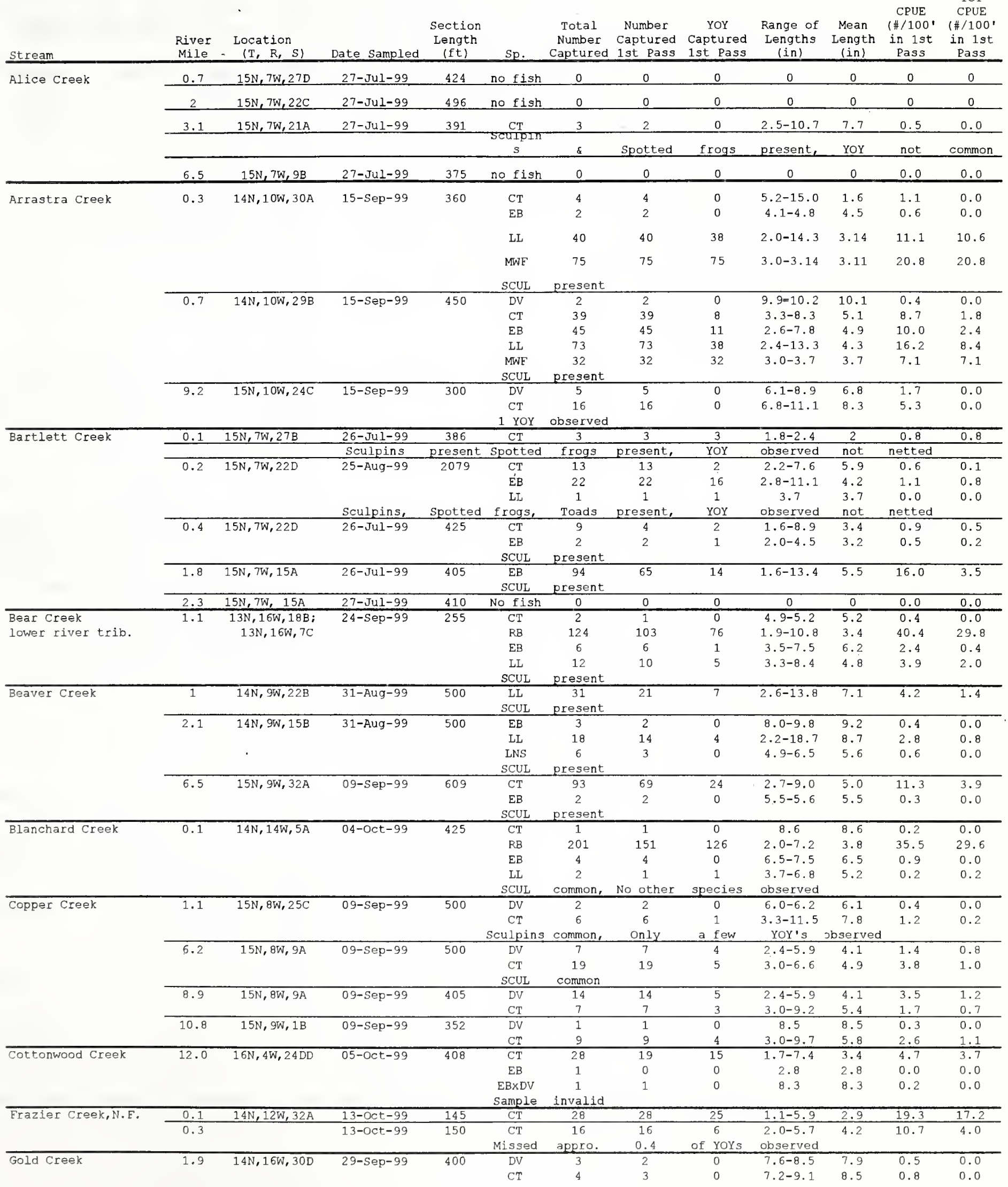




\begin{tabular}{|c|c|c|c|c|c|c|c|c|c|c|c|c|}
\hline Stream & $\begin{array}{l}\text { River } \\
\text { Mile } \\
\end{array}$ & $\begin{array}{l}\text { Location } \\
(\mathrm{T}, \mathrm{R}, \mathrm{S})\end{array}$ & Date Sampled & $\begin{array}{c}\text { Section } \\
\text { Length } \\
(f t) \\
\end{array}$ & $\mathrm{Sp}$. & $\begin{array}{c}\text { Total } \\
\text { Number } \\
\text { Captured }\end{array}$ & $\begin{array}{l}\text { Number } \\
\text { Captured } \\
\text { 1st Pass }\end{array}$ & $\begin{array}{c}\text { YOY } \\
\text { Captured } \\
13 t \text { Pass }\end{array}$ & $\begin{array}{c}\text { Range of } \\
\text { Lengths } \\
\text { (in) }\end{array}$ & $\begin{array}{c}\text { Mean } \\
\text { Length } \\
(\text { in) } \\
\end{array}$ & $\begin{array}{l}\text { CPUE } \\
\left\langle \# / 100^{\prime}\right. \\
\text { in 1st } \\
\text { Pass }\end{array}$ & $\begin{array}{c}\text { CPUE } \\
\text { (\#/100' } \\
\text { in 1st } \\
\text { Pass } \\
\end{array}$ \\
\hline \multirow[t]{3}{*}{ Gold Creek (cont.) } & 1.9 & $14 \mathrm{~N}, 16 \mathrm{~W}, 30 \mathrm{D}$ & $29-$ Sep-99 & 400 & $\mathrm{RB}$ & 41 & 24 & 2 & $2.7-12.2$ & 5.8 & 6.0 & 0.5 \\
\hline & & & & & LL & 31 & 24 & 2 & $3 \cdot 2-17 \cdot 4$ & 6.8 & 6.0 & 0.5 \\
\hline & & & & & Sculpinso & observed, & YOY's & present & but not & sampled & & \\
\hline \multirow[t]{10}{*}{ Hogum Creek } & 0.1 & $14 \mathrm{~N}, 7 \mathrm{~W}, 8 \mathrm{~B}$ & $28-J u l-99$ & 325 & $\mathrm{CT}$ & 2 & 1 & 0 & $8.0=9.1$ & 8.6 & 0.3 & 0.0 \\
\hline & & & & & LL & 1 & 1 & 0 & 6.3 & 6.3 & 0.3 & 0.0 \\
\hline & 0.4 & $14 \mathrm{~N}, 7 \mathrm{~W}, 8 \mathrm{~A}$ & $28-J u l-99$ & 405 & $\mathrm{CT}$ & 11 & 6 & 0 & $4.0-7.1$ & 5.5 & 1.5 & 0.0 \\
\hline & & & & & $\mathrm{EB}$ & 19 & 13 & 3 & $1.9-8.0$ & 5.4 & 3.2 & 0.7 \\
\hline & & & & & LL & 1 & 1 & 0 & 4.5 & 4.5 & 0.2 & 0.0 \\
\hline & & & & & MWE & 1 & 1 & 0 & 5.1 & 5.1 & 0.2 & 0.0 \\
\hline & & & & & Sculpins & present, & YOY & observed & but not & netted & & \\
\hline & 0.7 & $14 \mathrm{~N}, 7 \mathrm{~W}, 8 \mathrm{D}$ & $28-J u l-99$ & 396 & $\mathrm{CT}$ & 16 & 16 & 3 & $3.1-7.8$ & 5.5 & 4.0 & 0.8 \\
\hline & & & & & $\mathrm{EB}$ & 14 & 10 & 4 & $2.2-6.5$ & 4.9 & 2.5 & 1.0 \\
\hline & & & & & LL & 1 & 1 & $\underline{0}$ & 5.6 & 5.6 & 0.3 & 0.0 \\
\hline \multirow[t]{10}{*}{ Kleinschmidt Creek } & 0.5 & & $30-$ Sep-99 & 306 & EB & 3 & 3 & 1 & $3.8-4.3$ & 4.1 & 1.0 & 0.3 \\
\hline & & & & & LL & 70 & 48 & 41 & $2.8-9.0$ & 2.9 & 15.7 & 13.4 \\
\hline & & & & & SCUL & present & & & & & & \\
\hline & 0.8 & & $16-$ Sep-99 & 495 & $\mathrm{~EB}$ & 11 & 7 & 1 & $3.5-8.3$ & 5.2 & 1.4 & 0.2 \\
\hline & & & & & $\begin{array}{c}\text { LL } \\
\text { Scul }\end{array}$ & $\begin{array}{c}83 \\
\text { Present }\end{array}$ & 61 & 35 & $2.6-16.3$ & 5.3 & 12.3 & 7.1 \\
\hline & 1.1 & & 16-Sep-99 & 430 & DV & 1 & 1 & 0 & 6.6 & 6.6 & 0.2 & 0.0 \\
\hline & & & & & $\mathrm{EB}$ & 23 & 13 & 10 & $3.1-10.2$ & 4.2 & 3.0 & 2.3 \\
\hline & & & & & LL & 33 & 21 & 13 & $2.6-9.9$ & 5.9 & 4.9 & 3.0 \\
\hline & & & & & LNS & 2 & 2 & 0 & $7.7-8.3$ & 8.0 & 0.5 & 0.0 \\
\hline & & & & & SCUL & present & & & & & & \\
\hline \multirow[t]{9}{*}{ Landers Fork } & 0.1 & $14 \mathrm{~N}, 8 \mathrm{~W}, 13 \mathrm{~B}$ & $08-$ Sep-99 & 781 & $\mathrm{ct}$ & 2 & 2 & 0 & $4.3-4.4$ & 4.4 & 0.3 & 0.0 \\
\hline & & & & & Sculpins & present, & No YOYS & observed & & & & \\
\hline & 4.6 & $15 \mathrm{~N}, 8 \mathrm{~W}, 36 \mathrm{~B} \&$ & $08-\operatorname{sep}-99$ & 420 & DV & 2 & 2 & 0 & $5.8-6.2$ & 6.0 & 0.5 & 0.0 \\
\hline & & $25 D$ & & & $\mathrm{CT}$ & 1 & 1 & 0 & 9.5 & 9.5 & 0.2 & 0.0 \\
\hline & & & & & LL & 1 & 1 & 0 & 6.6 & 6.6 & 0.2 & 0.0 \\
\hline & & & & & Sculpins & present, & No YOYs & observed & & & & \\
\hline & 8.1 & $15 \mathrm{~N}, 8 \mathrm{~W}, 13 \mathrm{~A} \&$ & $08-5 e p-99$ & 500 & DV & 2 & 2 & 0 & 5.6 & 5.6 & 0.4 & 0.0 \\
\hline & & $12 \mathrm{C}$ & & & $\mathrm{CT}$ & 5 & 5 & 0 & $4.3-7.6$ & 5.9 & 1.0 & 0.0 \\
\hline & & & & & Sculpins & present, & No YOY 9 & observed & & & & \\
\hline \multirow[t]{4}{*}{ McCabe Creek } & 2.2 & $15 \mathrm{~N}, 12 \mathrm{~W}, 5 \mathrm{C}$ & 20-Jul-99 & 380 & $\mathrm{CT}$ & 9 & 6 & 2 & $2.4-10.1$ & 6.0 & 1.6 & 0.5 \\
\hline & & & & & $\mathrm{EB}$ & 4 & 2 & 0 & $3.9-5.9$ & 4.9 & 0.5 & 0.0 \\
\hline & 3.2 & $15 \mathrm{~N}, 12 \mathrm{~W}, 4 \mathrm{C}$ & 23-Aug-99 & 459 & $\mathrm{CT}$ & 32 & 24 & 2 & $2.9-9.5$ & 5.8 & 5.2 & 0.4 \\
\hline & & & & & Sculpins & present & & & & & & \\
\hline \multirow[t]{2}{*}{ Moose Creek } & 0.3 & $14 \mathrm{~N}, 10 \mathrm{~W}, 34 \mathrm{C}$ & $26-$ Aug-99 & 1260 & $\begin{array}{c}\text { CT } \\
\text { Spotted } \\
\end{array}$ & $\begin{array}{c}118 \\
\text { frogs, }\end{array}$ & $\begin{array}{c}118 \\
\text { Toads } \\
\end{array}$ & $\begin{array}{c}50 \\
\text { observed } \\
\end{array}$ & $2.4-7.1$ & 4.2 & 9.4 & 4.0 \\
\hline & 0.5 & & 26-Aug-99 & 525 & $\mathrm{CT}$ & 47 & 47 & 27 & $2.6-5.9$ & 3.9 & 9.0 & 5.1 \\
\hline Pearson Creek & 1.1 & $14 \mathrm{~N}, 13 \mathrm{~W}, 3 \mathrm{~B}$ & 16-Sep-99 & 480 & $\mathrm{CT}$ & 218 & 153 & 133 & $1.6-7.1$ & 2.6 & 31.9 & 27.7 \\
\hline \multirow[t]{10}{*}{ Poorman Creek } & 0.1 & $14 \mathrm{~N}, 9 \mathrm{~W}, 25 \mathrm{C}$ & 15-Aug-99 & 900 & LL & 2 & 2 & 0 & $17.8-18 \cdot 6$ & 18.1 & 0.2 & 0.0 \\
\hline & & & & & Sculpins & present, & $<6$ YOYs & observed & & & & \\
\hline & 4.4 & $13 \mathrm{~N}, 8 \mathrm{~W}, 8 \mathrm{CB}$ & $10-$ Aug-99 & 1540 & $\mathrm{CT}$ & 17 & 17 & 3 & $3.7-11.7$ & 7.0 & 1.1 & 0.2 \\
\hline & & & & & $\mathrm{Eb}$ & 18 & 18 & 2 & $2.6-16.6$ & 6.2 & 1.2 & 0.1 \\
\hline & & & & & LL & 10 & 10 & 3 & $2.4-12.4$ & 6.3 & 0.6 & 0.2 \\
\hline & & & & & Sculpins & present, & $<10$ YOYs & observed & & & & \\
\hline & 7.4 & $13 \mathrm{~N}, 8 \mathrm{~W}, 22 \mathrm{~A}$ & 10-Aug-99 & 924 & DV & 2 & 2 & 0 & $4.0-4.1$ & 4.1 & 0.2 & 0.0 \\
\hline & & & & & $\mathrm{CT}$ & 17 & 17 & 1 & $3.7-9.5$ & 7.0 & 1.8 & 0.1 \\
\hline & & & & & $E B$ & 4 & 4 & 1 & $3.9-9.9$ & 6.2 & 0.4 & 0.1 \\
\hline & & & & & SCUL & present & & & & & & \\
\hline Rock Creek & 1.7 & $14 \mathrm{~N}, 11 \mathrm{~W}, 5 \mathrm{~A}$ & 16-Aug-99 & 646 & $\mathrm{RB}$ & 1 & 1 & 0 & 5.8 & 5.8 & 0.2 & 0.0 \\
\hline & & & & & $\mathrm{EB}$ & 8 & 7 & 4 & $2.9-4.9$ & 3.7 & 1.1 & 0.6 \\
\hline & & & & & LND & 4 & 1 & 1 & $2.4-3.3$ & 2.8 & 0.2 & 0.2 \\
\hline & & & & & SCUL & present & & & & & & \\
\hline Salmon Creek & 1.3 & $15 \mathrm{~N}, 11 \mathrm{~W}, 13 \mathrm{~A}$ & 16-Aug- 99 & 759 & $\mathrm{CT}$ & 2 & 2 & 2 & $2.0-2.6$ & 2.3 & 0.3 & 0.3 \\
\hline & & & & & EB & 34 & 34 & 25 & $2.2-10.4$ & 4.1 & 4.5 & 3.3 \\
\hline & & & & & SCUL & present, & IND & common & & & & \\
\hline Sauerkraut Creek & 0.2 & $14 \mathrm{~N}, 9 \mathrm{~N}, 29 \mathrm{C}$ & $17-$ Aug-99 & 819 & DV & 4 & 4 & 0 & $7.7-11.0$ & 9.7 & 0.5 & 0.0 \\
\hline & & & & & $\mathrm{CT}$ & 14 & 14 & 2 & $3.4-9.5$ & 6.8 & 1.7 & 0.2 \\
\hline & & & & & EB & 80 & 80 & 14 & $2.3-11.4$ & 5.3 & 9.8 & 1.7 \\
\hline & & & & & LL & 14 & 14 & 3 & $3.4-11.4$ & 6.0 & 1.7 & 0.4 \\
\hline & & & & & Sculpins, & Spotted & Erogs & present & & & & \\
\hline & 2.7 & $13 \mathrm{~N}, 9 \mathrm{~W}, 5 \mathrm{D}$ & 18-Aug-99 & 675 & $\mathrm{CT}$ & 4 & 4 & 4 & $2.3-3.3$ & 2.9 & 0.6 & 0.6 \\
\hline & & - & & & $E B$ & 10 & 10 & 5 & $2.2-8.6$ & 5.0 & 1.5 & 0.7 \\
\hline & & & & & Spotted & frogs & present & & & & & \\
\hline & 3 & $13 \mathrm{~N}, 9 \mathrm{~W}, 5 \mathrm{D} \& 8 \mathrm{~A}$ & 18-Aug-99 & 821 & $\mathrm{CT}$ & 40 & 40 & 4 & $2.7-8.5$ & 5.2 & 4.9 & 0.5 \\
\hline & & & & & $\mathrm{EB}$ & 4 & 4 & 1 & $3.4-8.1$ & 5.7 & 0.5 & 0.1 \\
\hline & & & & & Spotted & frogs & present & & & & & \\
\hline & 5 & $13 \mathrm{~N}, 9 \mathrm{~W}, 18 \mathrm{~A}$ & 11-Aug-99 & 1000 & $\mathrm{CT}$ & 55 & 55 & 19 & $2.5-7.2$ & 4.7 & 5.5 & 1.9 \\
\hline & & & & & EB & 1 & 1 & 0 & 5.5 & 5.5 & 0.1 & 0.0 \\
\hline Seven-up Pete Creek & 0.1 & $14 \mathrm{~N}, 8 \mathrm{~W}, 14 \mathrm{D}$ & 09-Aug-99 & 2220 & $\mathrm{CT}$ & 22 & 22 & 5 & $2.7-5.5$ & 4.3 & 1.0 & 0.2 \\
\hline & & & & & EB & 2 & 2 & 0 & $6.3-7.8$ & 7.0 & 0.1 & 0.0 \\
\hline
\end{tabular}




\begin{tabular}{|c|c|c|c|c|c|c|c|c|c|c|c|c|}
\hline Stream & $\begin{array}{l}\text { River } \\
\text { Mile }\end{array}$ & $\begin{array}{l}\text { - Location } \\
(T, R, S) \\
\end{array}$ & Date Sampled & $\begin{array}{c}\text { Section } \\
\text { Length } \\
\text { (ft) }\end{array}$ & $\mathrm{Sp}$. & $\begin{array}{c}\text { Total } \\
\text { Number } \\
\text { Captured }\end{array}$ & $\begin{array}{c}\text { Number } \\
\text { Captured } \\
1 \text { st Pass }\end{array}$ & $\begin{array}{c}\text { YOY } \\
\text { Captured } \\
1 \text { st Pass } \\
\end{array}$ & $\begin{array}{c}\text { Range of } \\
\text { Lengths } \\
\text { (in) }\end{array}$ & $\begin{array}{c}\text { Mean } \\
\text { Length } \\
\text { (in) }\end{array}$ & $\begin{array}{c}\text { CPUE } \\
\text { (\#/100 } \\
\text { in 1st } \\
\text { Pass } \\
\end{array}$ & $\begin{array}{c}\text { YOY } \\
\text { CPUE } \\
\text { (\#/100' } \\
\text { in 1st } \\
\text { Pass } \\
\end{array}$ \\
\hline \multirow{2}{*}{ Seven-up Pete Creek } & $\begin{array}{ll}1 & 0.1\end{array}$ & $14 \mathrm{~N}, 8 \mathrm{~W}, 14 \mathrm{D}$ & 09 -Aug-99 & Spotted & frogs & present, & Very low & numbers & of YOYS & Jbserved & & \\
\hline & 0.5 & $\begin{array}{c}14 \mathrm{~N}, 8 \mathrm{~W}, 13 \mathrm{C} \\
824 \mathrm{~B} \\
\end{array}$ & 09-Aug-99 & 1740 & $\mathrm{CT}$ & 11 & 11 & 1 & $3.5-5.3$ & 4.6 & 0.6 & 0.1 \\
\hline \multirow{18}{*}{$\begin{array}{l}\text { Spring Creek, } \\
\text { Trib.to Upper } \\
\text { cottonwood Creek } \\
\text { Willow Creek } \\
\text { above Lincoln }\end{array}$} & 0.2 & $16 \mathrm{~N}, 14 \mathrm{~W}, 24 \mathrm{~A}$ & $30-$ sep-99 & 318 & $\begin{array}{l}\mathrm{CT} \\
\mathrm{EB}\end{array}$ & $\begin{array}{c}6 \\
50\end{array}$ & $\begin{array}{c}6 \\
50\end{array}$ & $\begin{array}{c}0 \\
34\end{array}$ & $\begin{array}{l}4.1-7.3 \\
2.3-9.0\end{array}$ & $\begin{array}{l}5.5 \\
3.6\end{array}$ & $\begin{array}{c}1.9 \\
15.7\end{array}$ & $\begin{array}{l}0.0 \\
10.7\end{array}$ \\
\hline & & & & & $1 \mathrm{CT} \mathrm{YOY}$ & observed & & & & & & \\
\hline & 0.1 & $\begin{array}{c}14 \mathrm{~N}, 7 \mathrm{~W}, 34 \mathrm{D \&} \\
35 \mathrm{C} \\
\end{array}$ & 03-Aug-99 & 421 & $\mathrm{CT}$ & 4 & 4 & 1 & $4 \cdot 0-7.2$ & 5.8 & 1.0 & 0.2 \\
\hline & 0.7 & $15 \mathrm{~N}, 7 \mathrm{~W}, 35 \mathrm{D}$ & 19-Aug-99 & 947 & CT & 4 & 4 & 1 & $3.9-6.4$ & 5.4 & 0.4 & 0.1 \\
\hline & & & & & $\mathrm{EB}$ & 18 & 18 & 1 & $2.6-11.7$ & 7.1 & 1.9 & 0.1 \\
\hline & & & & & LNS & 4 & 4 & 0 & $4.3-6.7$ & 5.1 & 0.4 & 0.0 \\
\hline & & & & & Spotted & frogs, & Toads & present & & & & \\
\hline & 1.1 & $14 \mathrm{~N}, 7 \mathrm{~W}, 2 \mathrm{~A}$ & 02-Aug-99 & 540 & $\mathrm{CT}$ & 3 & 2 & 0 & $5.2-8.1$ & 6.3 & 0.4 & 0.0 \\
\hline & & & & & $\begin{array}{c}E B \\
E N S\end{array}$ & $\begin{array}{l}9 \\
3\end{array}$ & 7 & 0 & $2.3-11.2$ & $\begin{array}{l}6.1 \\
5.3\end{array}$ & $\begin{array}{l}1.3 \\
0.4\end{array}$ & $\begin{array}{l}0.0 \\
0.0\end{array}$ \\
\hline & & & & & LNS & 3 & 2 & 0 & $4.3-6.9$ & 5.3 & 0.4 & 0.0 \\
\hline & 1.6 & $14 \mathrm{~N}, 7 \mathrm{~W}, 1 \mathrm{~B}$ & 19 -Aug-99 & 815 & $\mathrm{CT}$ & 2 & 2 & 0 & $5.4-6.7$ & 6.0 & 0.2 & 0.0 \\
\hline & & & & & $E B$ & 49 & 49 & 11 & $2.2-9.3$ & 4.9 & 6.0 & 1.3 \\
\hline & & & & & LL & 1 & 1 & 0 & 11.1 & 11.1 & 0.1 & 0.0 \\
\hline & & & & & LNS & 2 & 2 & 0 & $5.5-6.9$ & 6.2 & 0.2 & 0.0 \\
\hline & & & & & Spotted & frogs & present & & & & & \\
\hline & 4.1 & $14 \mathrm{~N}, 6 \mathrm{~W}, 8 \mathrm{C}$ & $02-$ Aug- 99 & 682 & $\mathrm{CT}$ & 1 & 1 & 0 & 5.3 & 5.3 & 0.1 & 0.0 \\
\hline & & & & & $E B$ & 16 & 13 & 8 & $1.7-9.4$ & 3.8 & 1.9 & 1.2 \\
\hline & & & & & Sculpins, & spotted & Erogs & present & & & & \\
\hline \multirow{8}{*}{$\begin{array}{l}\text { Willow Creek } \\
\text { below Lincoln }\end{array}$} & 1.8 & $14 \mathrm{~N}, 9 \mathrm{~W}, 28 \mathrm{D}$ & 04 -Aug-99 & 396 & LL & 5 & 4 & 0 & $5 \cdot 9-14.8$ & 7.9 & 1.0 & 0.0 \\
\hline & & & & & LNS & 1 & 0 & 0 & 6.4 & 6.4 & 0.0 & 0.0 \\
\hline & & & & & Sculpins, & L Spotted & frogs & present & & & & \\
\hline & 5.1 & $13 \mathrm{~N}, 9 \mathrm{~W}, 3 \mathrm{C}$ & 03 -Aug-99 & 420 & $\mathrm{CT}$ & 12 & 7 & 2 & $2.6-7.9$ & 4.9 & 1.7 & 0.5 \\
\hline & & & & & $E B$ & 6 & 3 & 0 & $3.8-10.2$ & 5.5 & 0.7 & 0.0 \\
\hline & & & & & SCUL & present & & & & & & \\
\hline & 5.7 & $13 \mathrm{~N}, 9 \mathrm{~W}, 10 \mathrm{C}$ & 11-Aug-99 & 519 & $\mathrm{CT}$ & 34 & 24 & 9 & $2.5-8.9$ & 5.0 & 4.6 & 1.7 \\
\hline & & & & & $\begin{array}{c}\text { EB } \\
\text { SCUL }\end{array}$ & $\begin{array}{c}17 \\
\text { present }\end{array}$ & 15 & 1 & $3.5-7.5$ & 5.5 & 2.9 & 0.2 \\
\hline \multirow{4}{*}{$\begin{array}{l}\text { West Fork. } 1 \text { from } \\
\text { confluence } \\
\text { East Fork.1 from } \\
\text { confluence }\end{array}$} & 6.1 & & 03-Aug-99 & 460 & $\mathrm{CT}$ & 4 & 2 & 1 & $3.2-4.1$ & 3.2 & 0.4 & 0.2 \\
\hline & & & & & $\mathrm{EB}$ & 1 & 1 & 0 & 5.3 & 5.3 & 0.2 & 0.0 \\
\hline & 6.1 & & 04-Aug-99 & 392 & CT & 2 & 1 & 0 & $5.9-6.1$ & 6.0 & 0.3 & 0.0 \\
\hline & & & & & $\begin{array}{c}\text { EB } \\
\text { SCUL }\end{array}$ & $\begin{array}{c}6 \\
\text { present }\end{array}$ & 4 & 1 & $3.9-6.3$ & 5.0 & 1.0 & 0.3 \\
\hline
\end{tabular}


Appendix E. Location maps and table of restoration streams and activities through 1999.
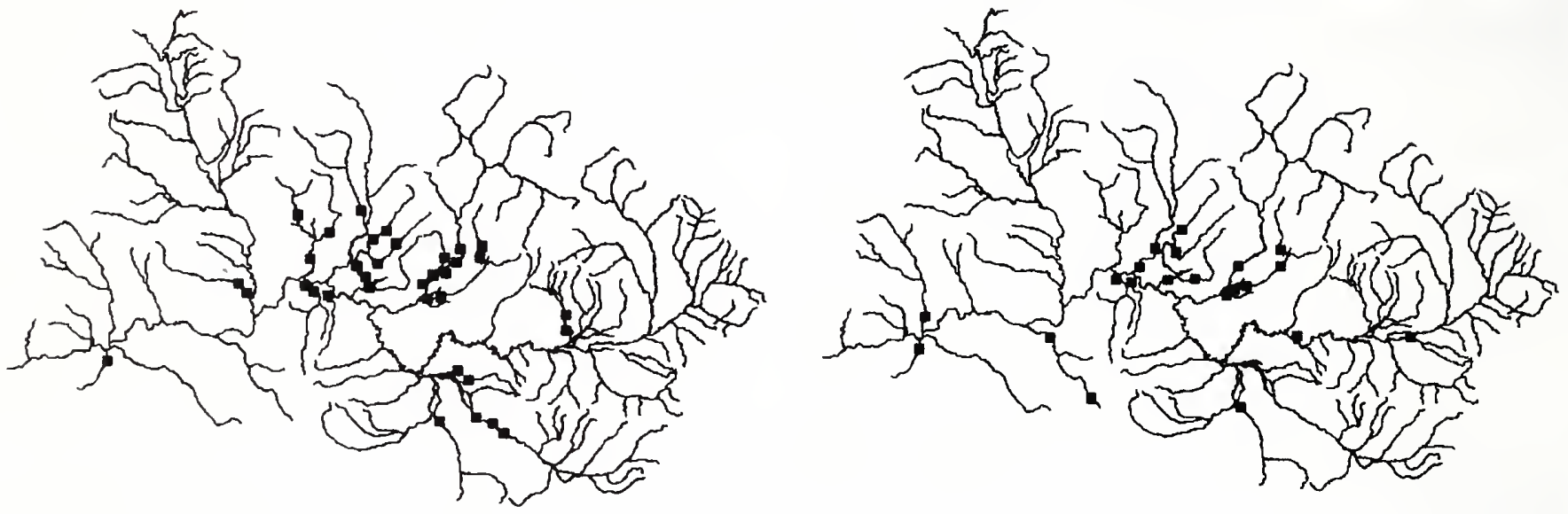

Irrigation upgrades in the Blackfoot Watershed, 19891999.
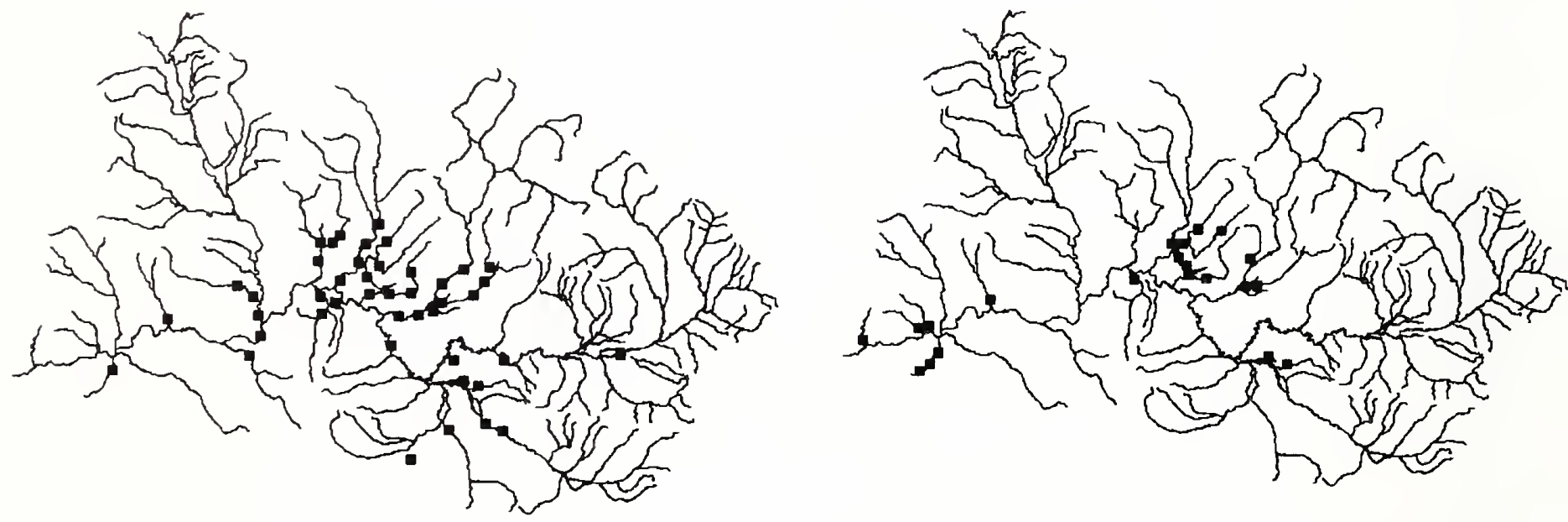

Habitat restoration work in the Blackfoot RiverWatershed, 1989-1999.
Road Crossing upgrades in the Blackfoot Watershed, 1989-1999. 


\begin{tabular}{|c|c|c|c|c|c|c|c|c|c|c|c|c|c|c|c|c|c|c|c|c|c|c|c|c|c|}
\hline 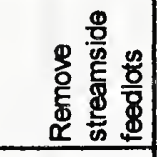 & & & & $x \mid x$ & & & & & & $x$ & & & & $\times$ & & $x$ & $<|\times|$ & $\times \mid$ & & & & & & & \\
\hline 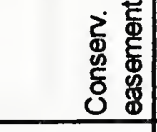 & & & & $\times$ & & & $x$ & & $|x|>$ & $x \mid>$ & & & & $\times$ & & $x$ & 4 & $\times \mid$ & & & & & & & $x$ \\
\hline 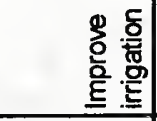 & & & & $x \mid x$ & & & $x$ & & & & & $\times \mid$ & & $\times$ & & $x$ & $<\mid \times$ & $\times$ & $x$ & & & & & & $x$ \\
\hline 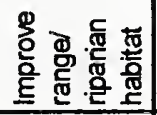 & & & & $x \mid x$ & & & & $x \mid$ & & $x \mid \times$ & & $x \mid$ & & $\times$ & & $x$ & $<\times$ & $x \mid$ & & $x \mid$ & & & & $\times$ & $x$ \\
\hline 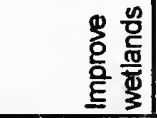 & & & & $\times$ & & & $x$ & & & $x$ & & & & $\times$ & & $x$ & $<$ & $\times \mid$ & & $\times \mid$ & & & & $x$ & \\
\hline 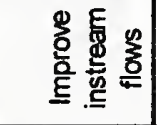 & & & & $x \mid x$ & & & & & $|x|>$ & $x$ & & $\times \mid$ & & $\times$ & & $x$ & $<$ & $\times \mid$ & & & & & & & \\
\hline 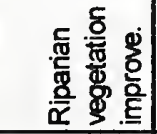 & & & & $x \mid x$ & & & & & & & & $\times \mid$ & & $\times$ & & $x$ & $<|x|$ & $\times$ & & $\times \mid$ & & & & $\times$ & $x$ \\
\hline 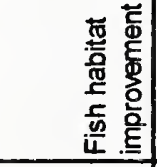 & & & & $x \mid x$ & & & & & & & & & & $x$ & & & & $x$ & & $x$ & & & $x$ & $\times$ & \\
\hline 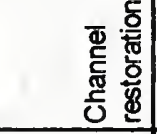 & & & & $x \mid x$ & & & & & & & & & & $\times$ & & & $\times$ & $x$ & $x$ & $x$ & & & & $x$ & \\
\hline 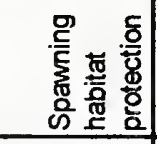 & & & & & & & & $x$ & & & & & & $x$ & & & & & & & & & & & \\
\hline 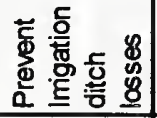 & & & & & & & $x$ & & & & & $x \mid$ & & $x$ & & $x$ & < & $x$ & $x$ & & & & & & \\
\hline 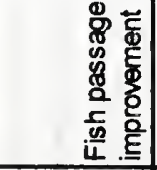 & & & & $x$ & & & $x$ & $x$ & & & $\frac{\varrho}{\omega}$ & $\times$ & & $x$ & & $x$ & $\langle\times|$ & $x$ & & $x$ & $x$ & & $x$ & $\times$ & $x$ \\
\hline 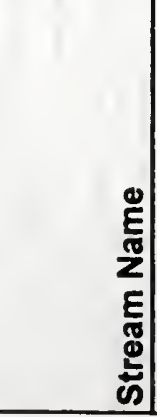 & $\begin{array}{l}\frac{1}{8} \\
\frac{1}{0} \\
8 \\
\frac{8}{2}\end{array}$ & 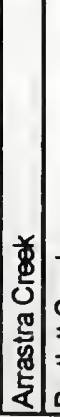 & 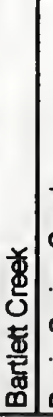 & 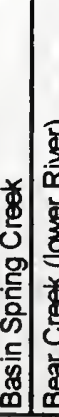 & 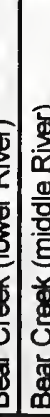 & 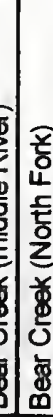 & 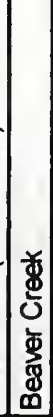 & 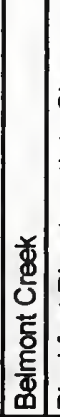 & 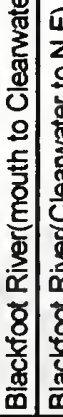 & 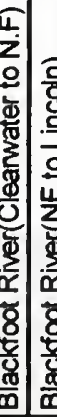 & 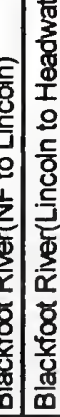 & 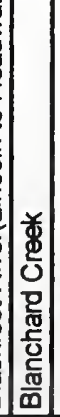 & 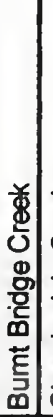 & 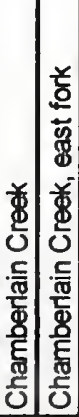 & 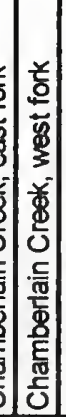 & 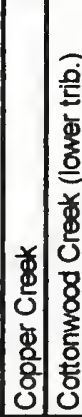 & 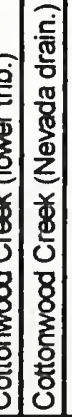 & 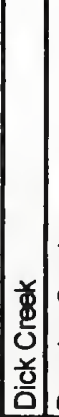 & 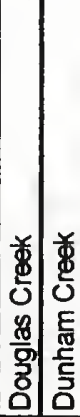 & $\mid$ & 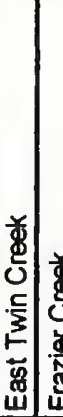 & 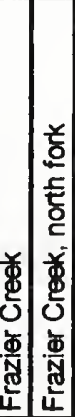 & 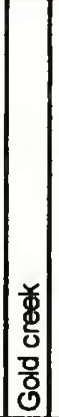 & 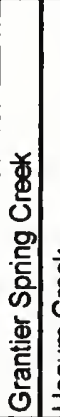 & 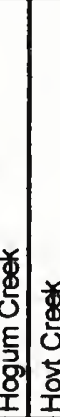 \\
\hline
\end{tabular}




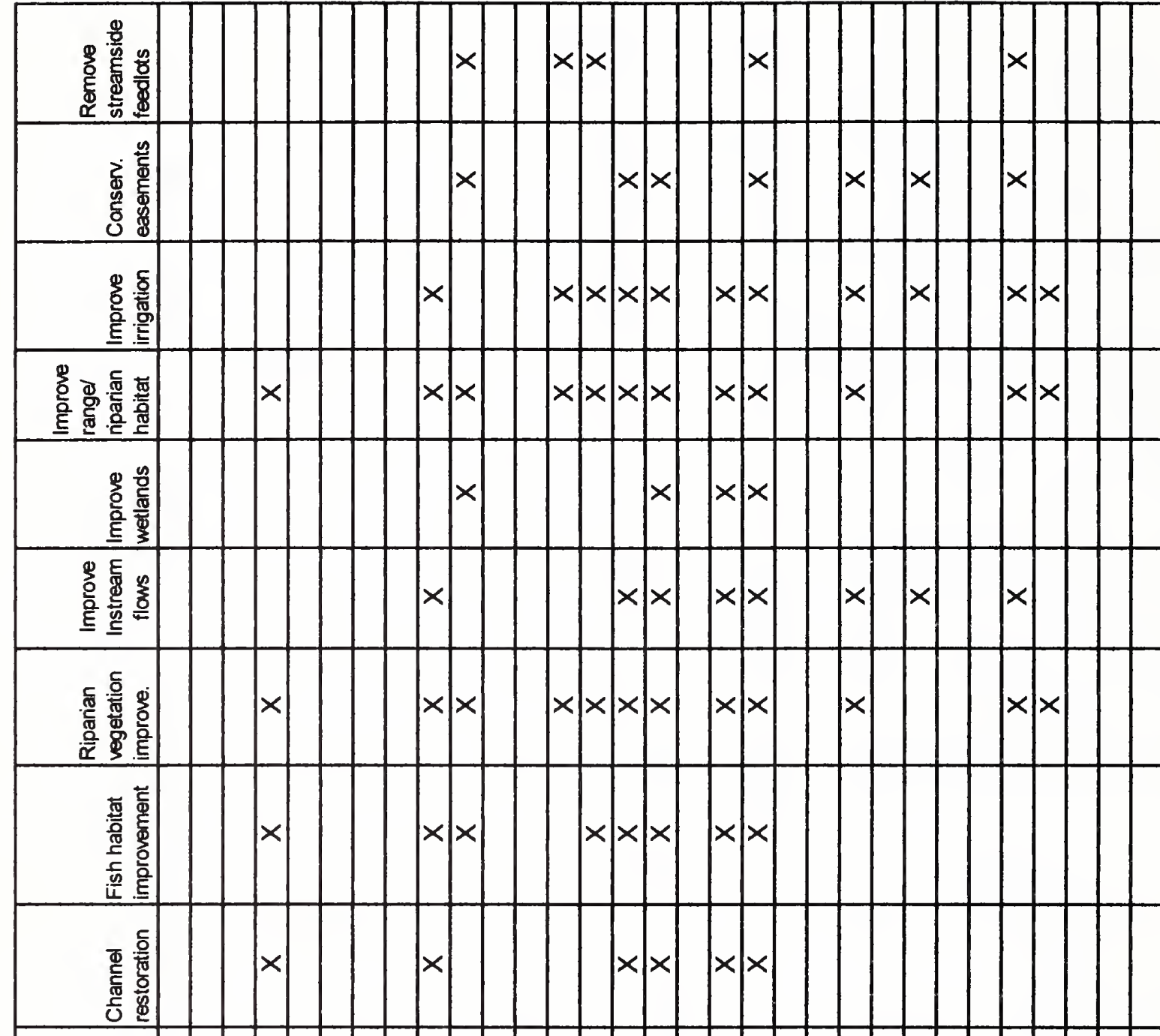

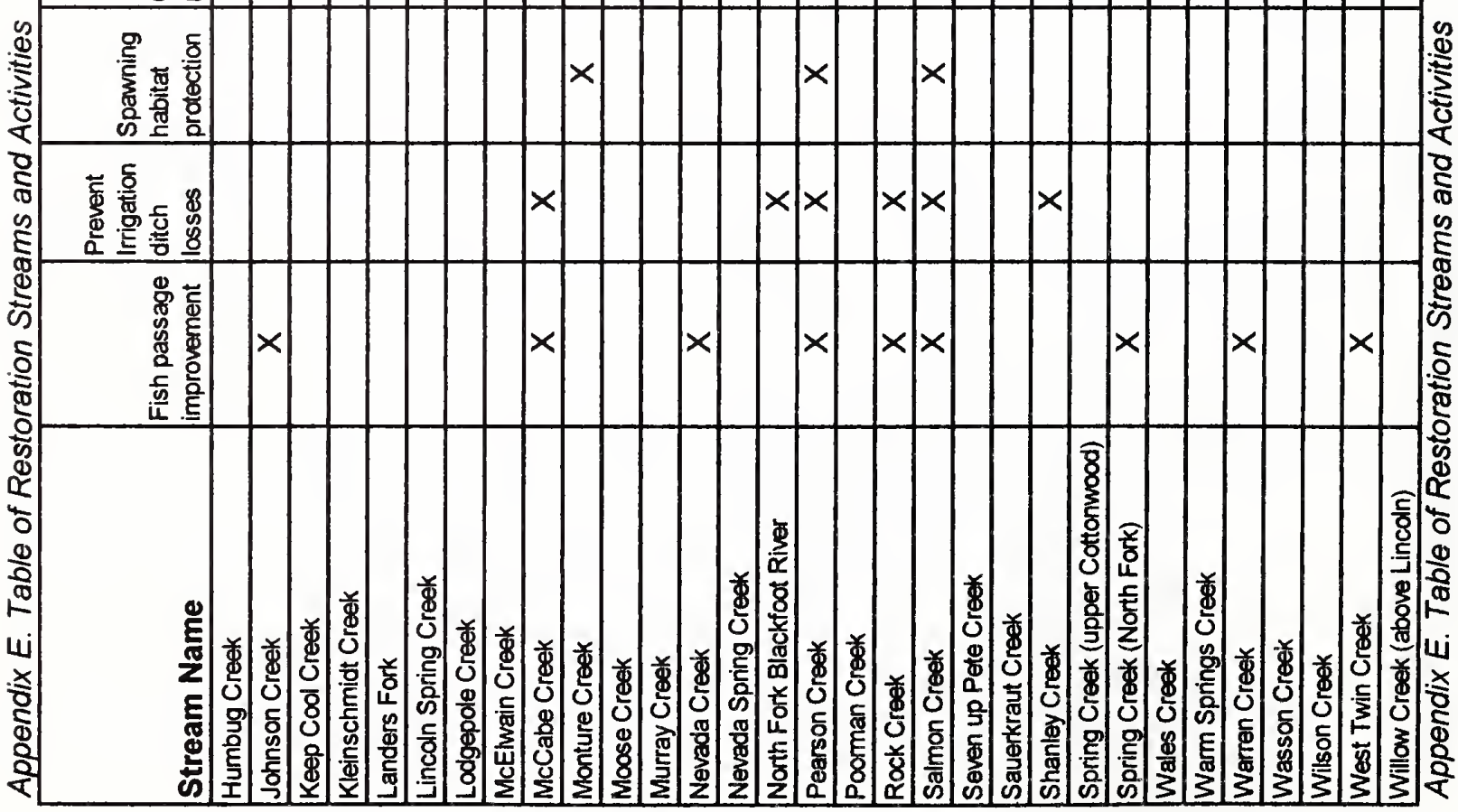




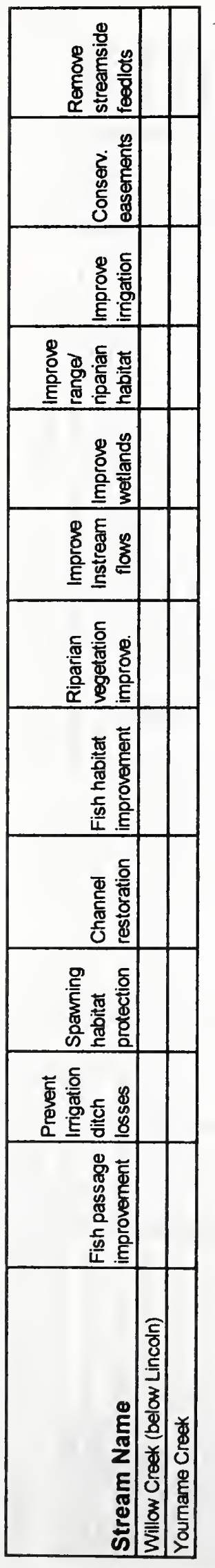




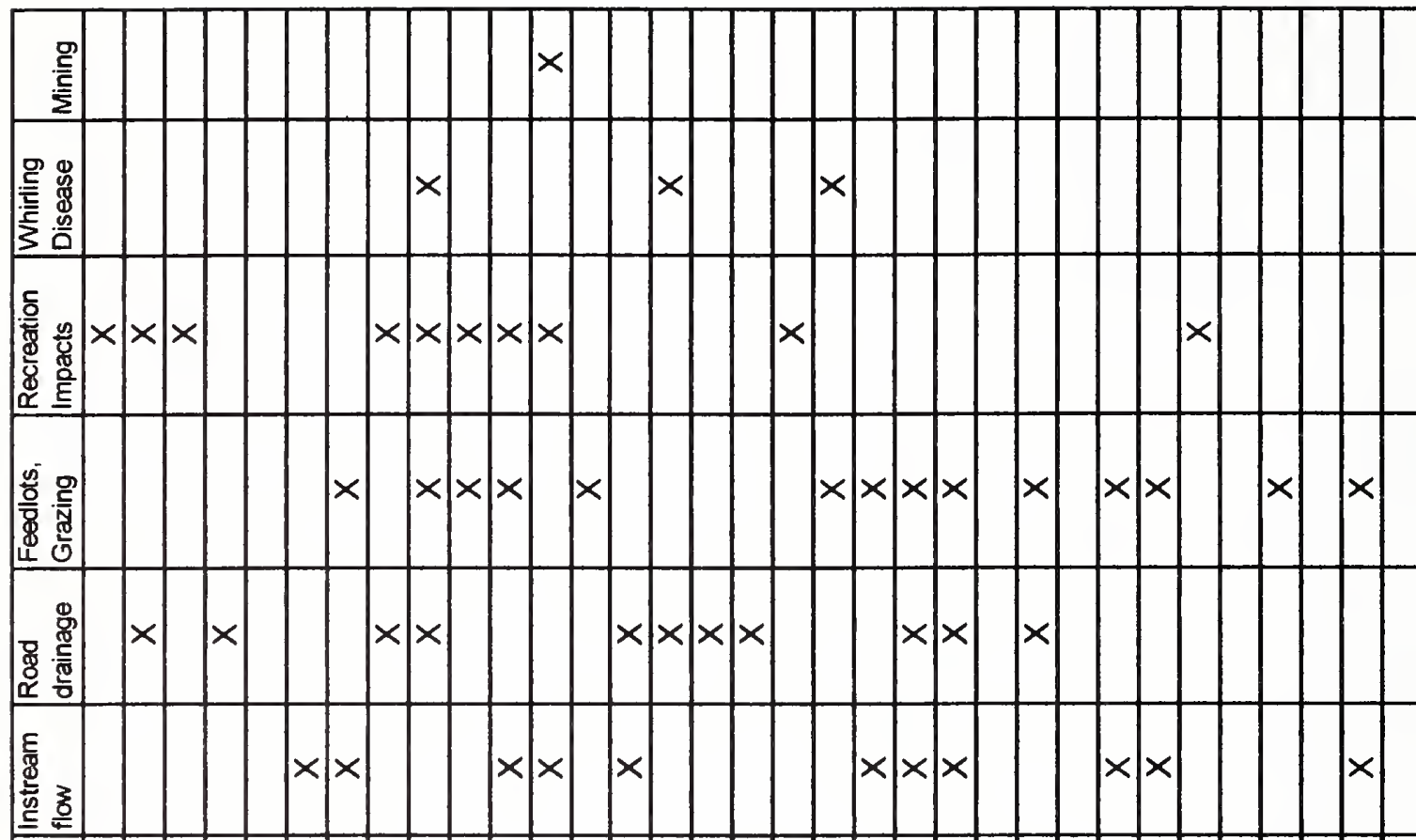

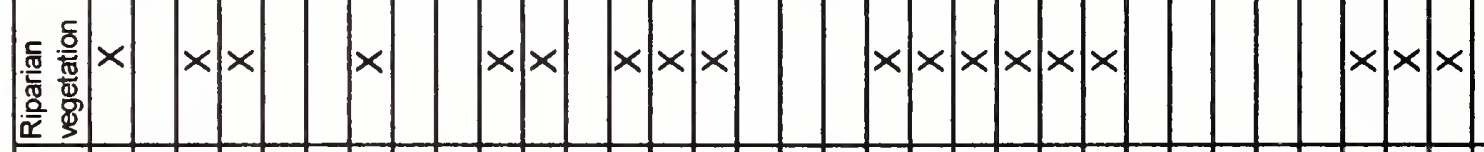

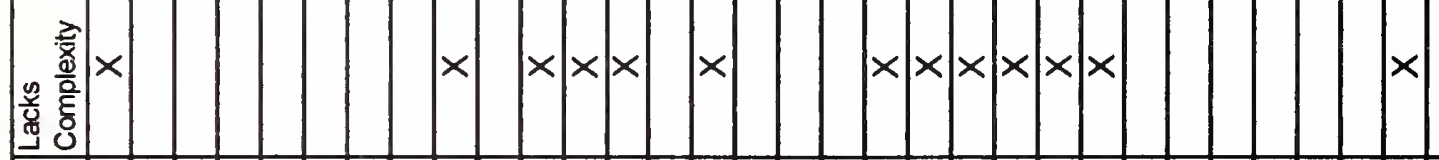

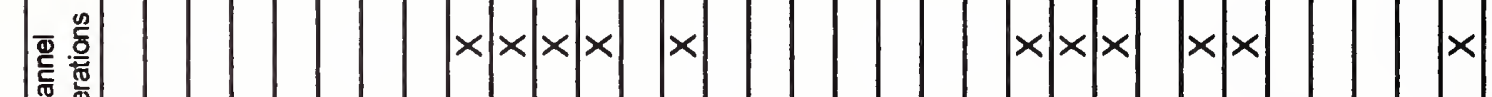

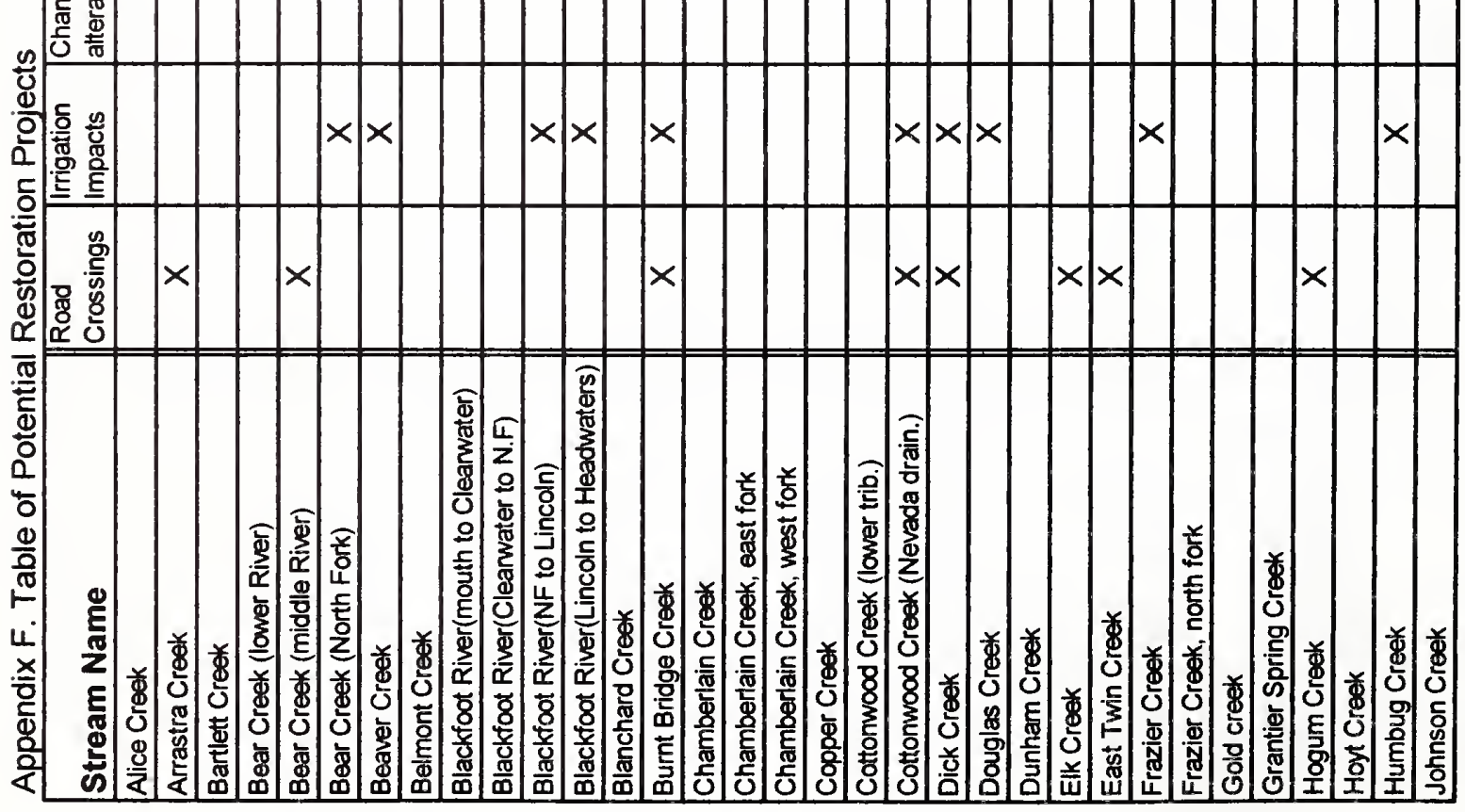




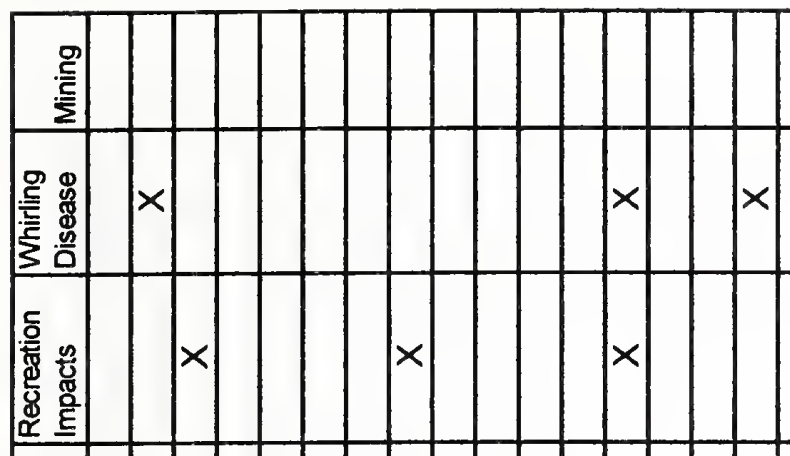

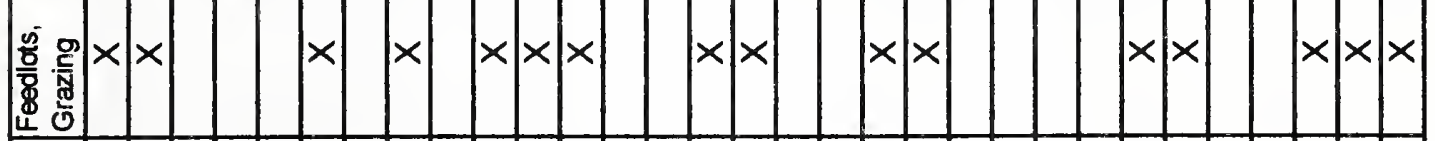

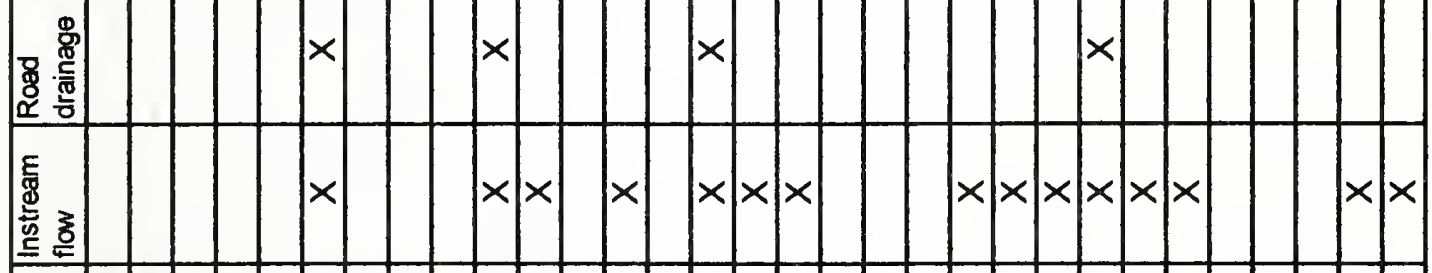

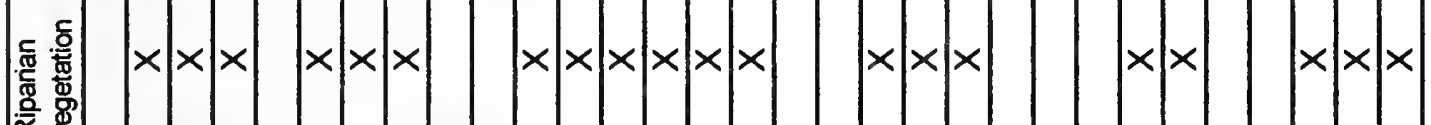

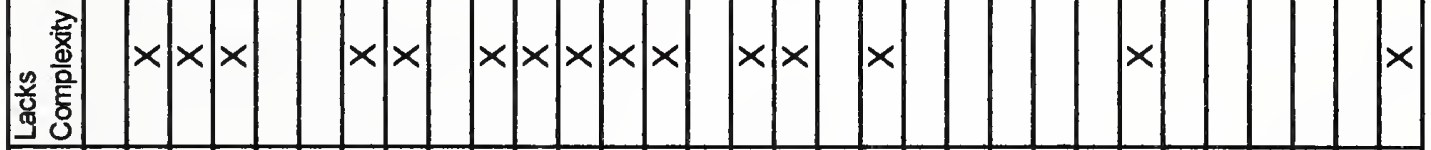

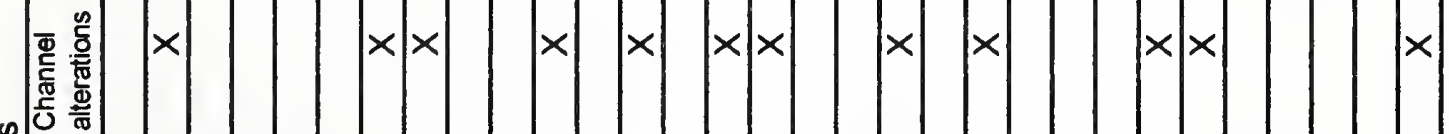

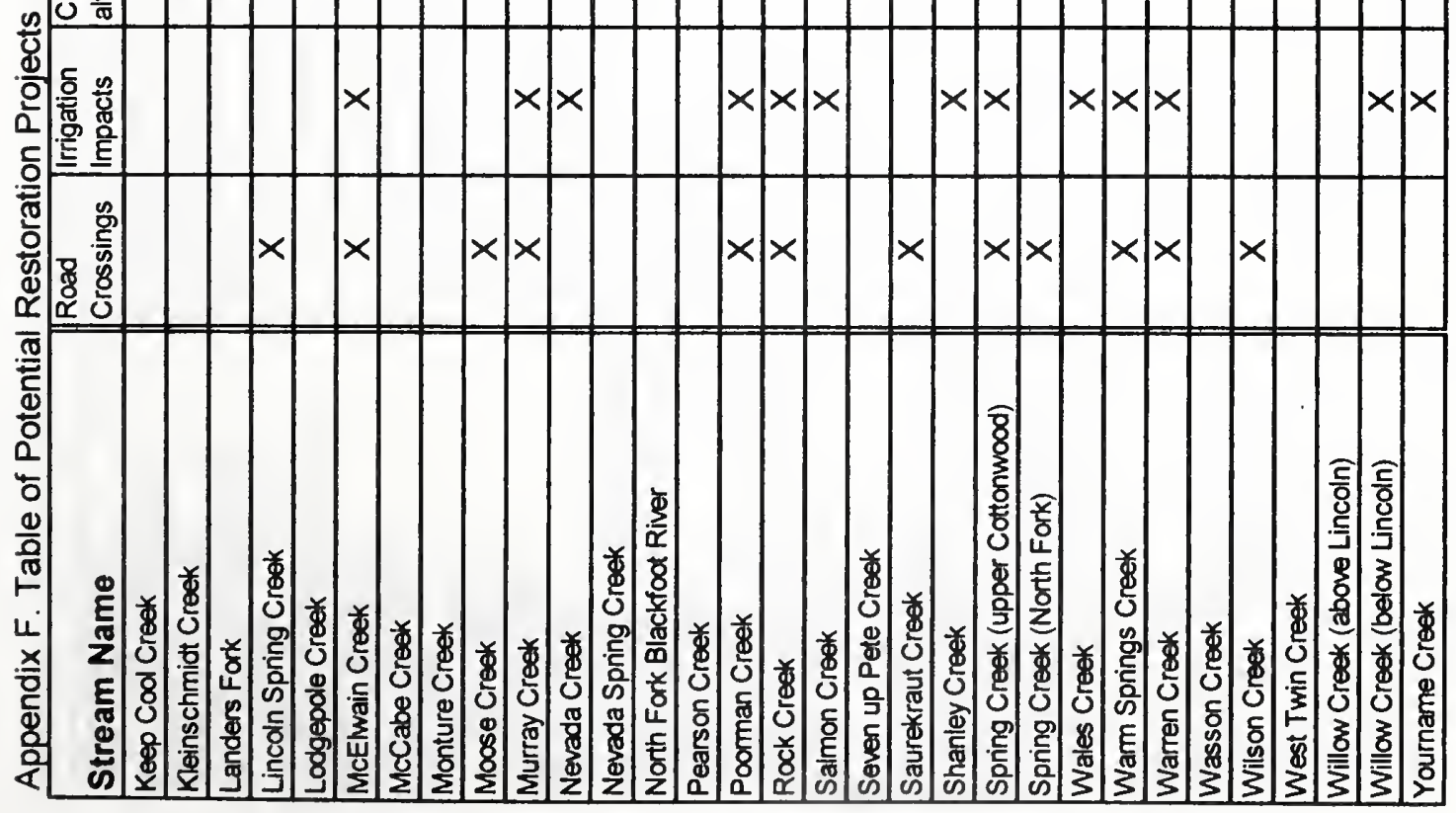




\begin{tabular}{|c|c|c|c|c|c|c|c|c|c|c|c|c|c|c|c|c|c|c|c|c|c|c|c|c|c|}
\hline 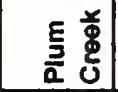 & & & $x$ & & & & $\times$ & $x$ & & & & & $x \mid x$ & $<x$ & & & $x$ & & & $x$ & & $x$ & & & \\
\hline$\frac{8}{2}$ & & & $x$ & & & & & & & & & & & & & & & & & & & $x$ & & & $x$ \\
\hline 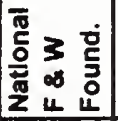 & & & & & & & & & & & & & $x$ & & & & & & & $x$ & & & & & \\
\hline 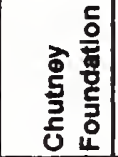 & & & & & & & & & & & & & & & & & & & & & & & & & \\
\hline 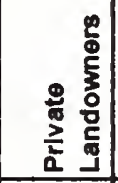 & & & $x$ & & & $\times$ & & & $x \mid x$ & & & & $\times$ & & & $\times$ & $x$ & & $x \mid x$ & $x$ & & $x$ & $|x| x$ & $\times$ & $\times$ \\
\hline $\begin{array}{l}2 \\
0 \\
0 \\
\text { 兽 }\end{array}$ & & & $x$ & & & $x \mid$ & $x \mid$ & & $x \mid x$ & & $x$ & & $\times$ & & & $\times$ & $x$ & $|x|$ & $x \mid \times$ & $x$ & & $x$ & $|x| x$ & $\times$ & $\times$ \\
\hline $\begin{array}{l}0 \\
0 \\
\frac{0}{2}\end{array}$ & & & & & & & & & & & & & & & & & & & & & & & & & \\
\hline $\begin{array}{l} \\
\frac{\alpha}{z} \\
\frac{z}{2} \\
\end{array}$ & & & & & & & & & & & $\times$ & & & & & $x$ & & & & & & $x$ & & & \\
\hline$\frac{5}{\Sigma}$ & & & & & & & & & & & & & & & & & & & & & & & & & \\
\hline $\begin{array}{l}\frac{2}{5} \\
3\end{array}$ & & & & & & & & & & & & & & & & & & & $x$ & & & & & & \\
\hline $\begin{array}{l}\mathscr{0} \\
\frac{\alpha}{2} \\
\end{array}$ & & & & & & & & & & & & & & & & & $\times$ & $\mid x$ & & & & & & & \\
\hline$\frac{\sum}{\mathbf{m}}$ & & & & & & & & & & & $\times$ & & $x \mid x$ & $<x$ & & $\times$ & & & $x$ & $x$ & & $\times$ & & & \\
\hline $\begin{array}{l}0 \\
3 \\
5 \\
3 \\
\end{array}$ & & & $x$ & & & $\times \mid$ & & & $x \mid x$ & & $\times$ & & $x \mid x$ & $<$ & & $x \mid x$ & $x \mid x$ & $|x|>$ & $x \times$ & $x$ & & $\times$ & $x \mid x$ & $x$ & $\times$ \\
\hline$\frac{0}{3}$ & & & $x$ & & & & & $\begin{array}{l} \\
\text { (v) }\end{array}$ & $x \times$ & $\frac{\Phi}{\stackrel{9}{9}}$ & $\times$ & & $\times \mid \times$ & < & & $x$ & $x$ & $|x|>$ & $x \mid x$ & $x$ & & $x$ & $x \mid x$ & $x$ & $x$ \\
\hline 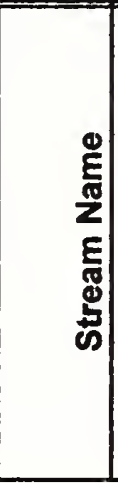 & 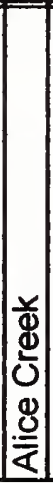 & 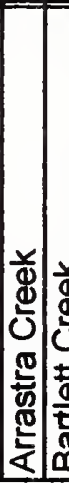 & 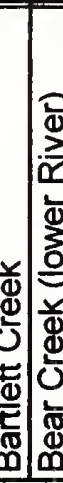 & 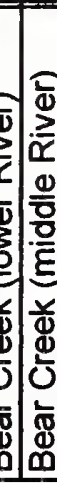 & 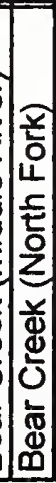 & 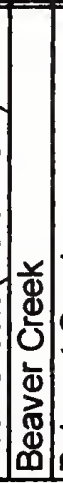 & 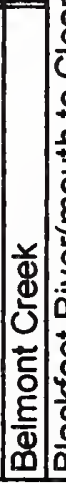 & 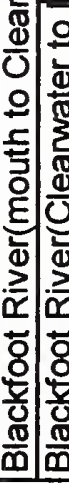 & 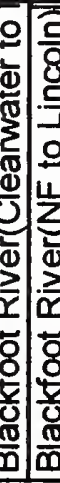 & 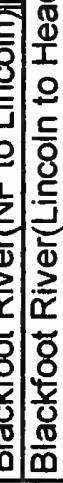 & 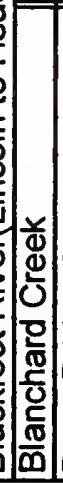 & 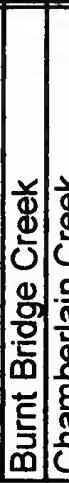 & 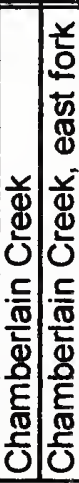 & 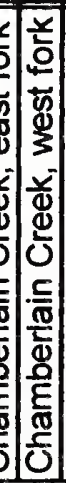 & 遂 & 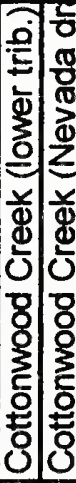 & 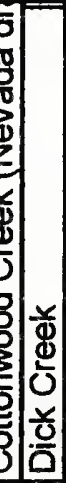 & 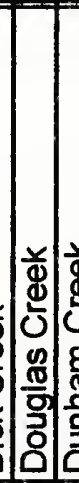 & 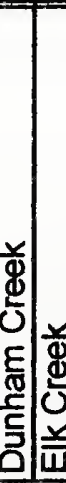 & 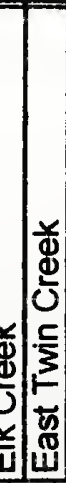 & 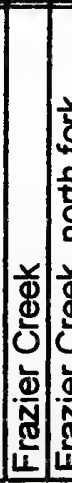 & 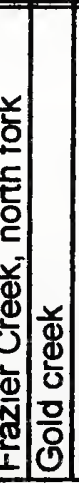 & 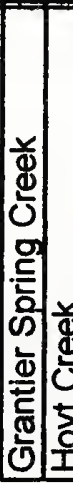 & 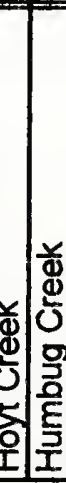 & 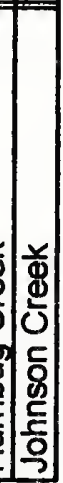 \\
\hline
\end{tabular}




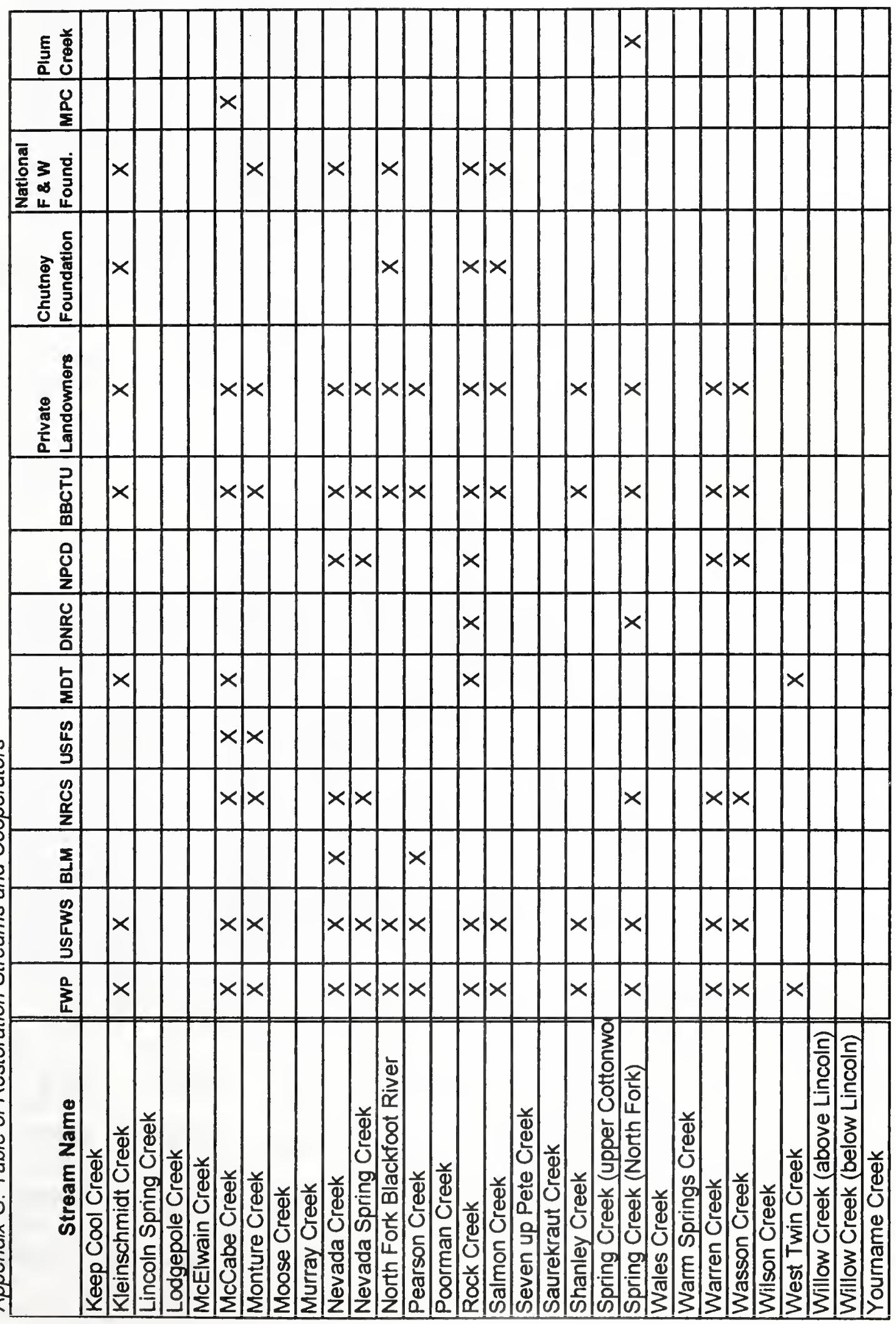




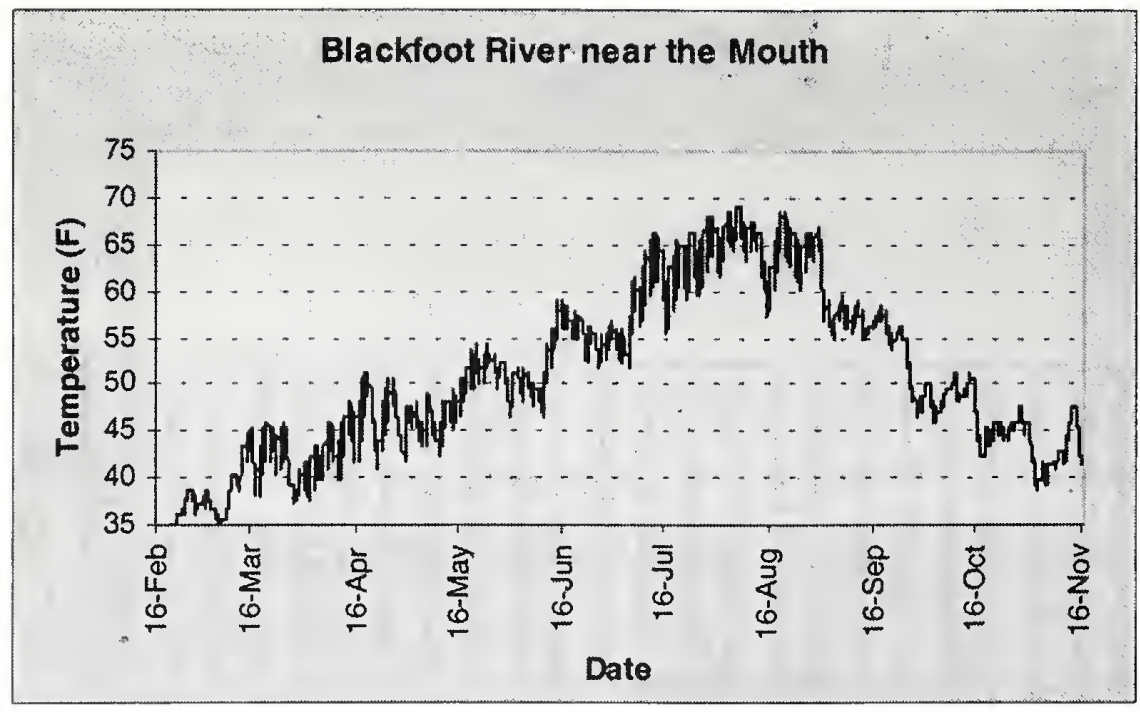

Month February March April May June July August September October $\begin{array}{llllllllll}\text { Monthly } & 35.8 & 40.0 & 44.4 & 48.5 & 53.2 & 60.6 & 64.4 & 55.1 & 46.8\end{array}$ Mean

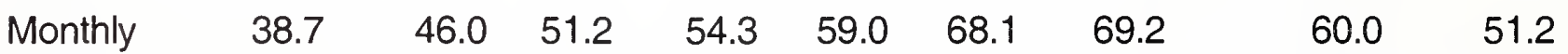
Max Monthly Min Stdev

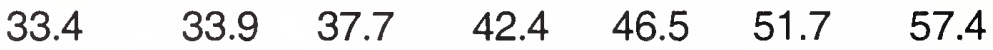
46.5 42.4 1.5 $3.1 \quad 3.1$ 3.0 $3.1 \quad 4.0$ 2.4

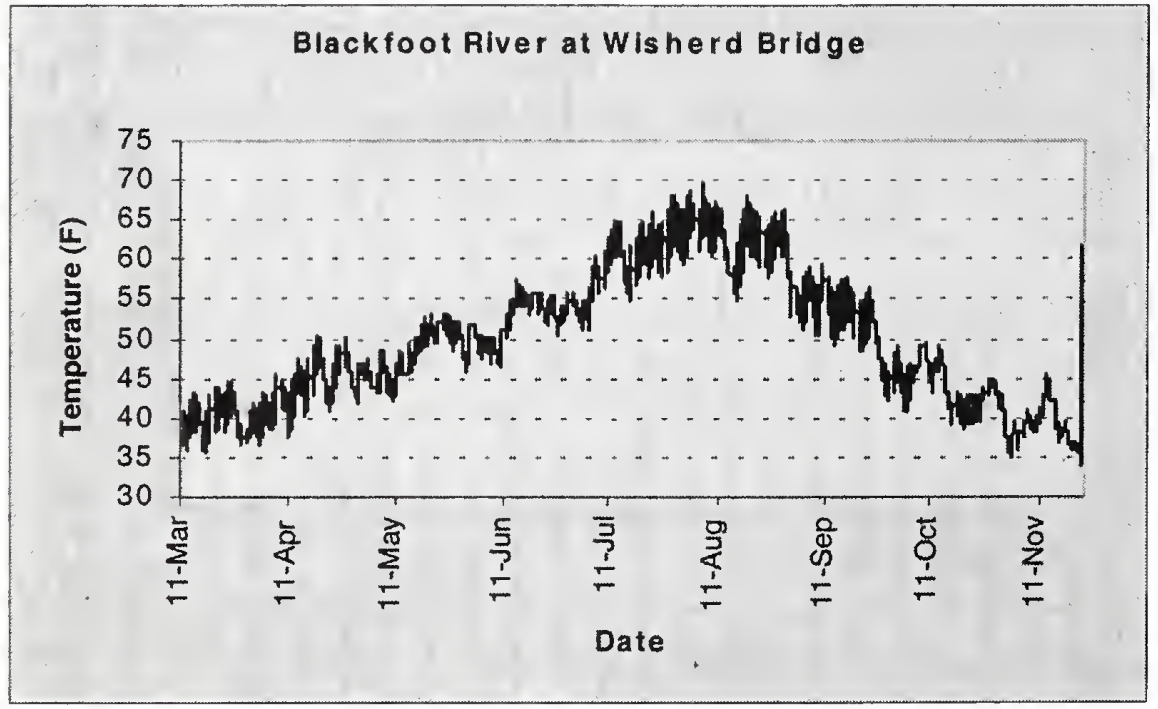

Month March April May June July August September October November

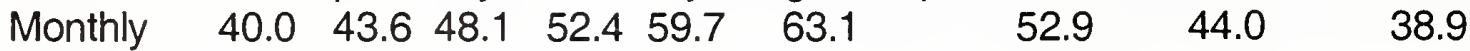
Mean

$\begin{array}{llllll}\text { Monthly } \quad 44.4 & 50.7 & 53.2 & 57.4 & 68.1 & 69.7\end{array}$ Max

$\begin{array}{lllllll}\text { Monthly } & 35.5 & 36.6 & 42.3 & 46.5 & 51.2 & 54.8\end{array}$ Min

Stdev

$59.5 \quad 49.6 \quad 61.6$

$\begin{array}{lll}42.3 & 38.7 & 33.9\end{array}$

$\begin{array}{lll}3.8 & 2.6 & 2.5\end{array}$




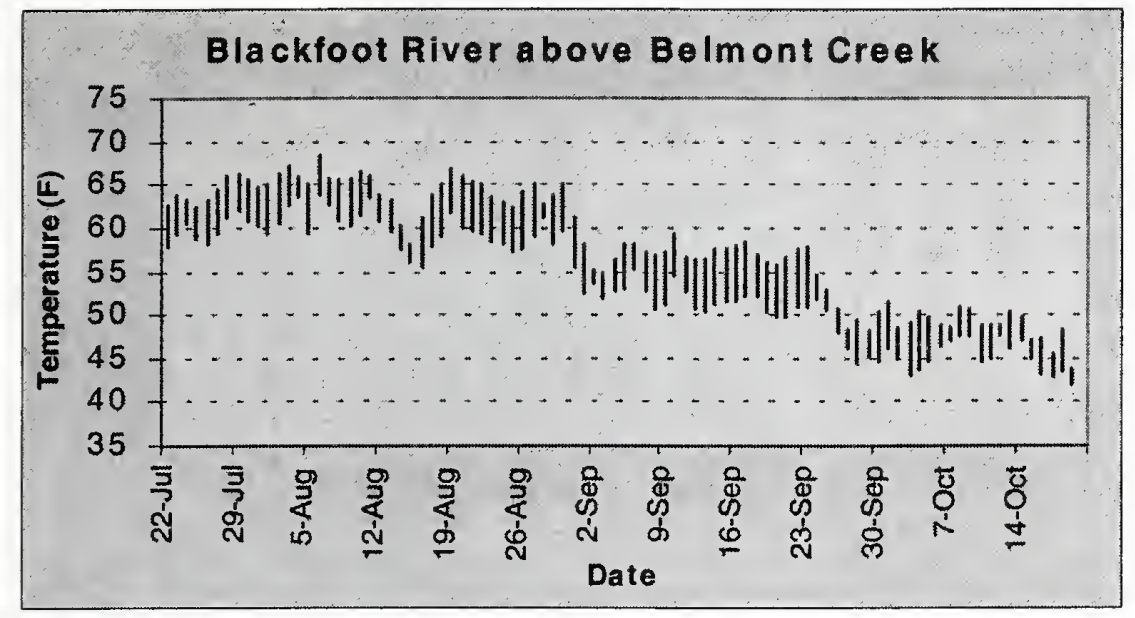

Month July August September October

$\begin{array}{lllll}\text { Monthly } & 62.3 & 62.1 & 53.1 & 47.0\end{array}$

Average

Monthly

$\begin{array}{llll}66.4 & 68.4 & 59.2 & 51.7\end{array}$

Max

$\begin{array}{lllll}\text { Monthly } & 57.8 & 55.0 & 44.4 & 41.9\end{array}$

Min

$\begin{array}{lllll}\text { Stdev } & 2.0 & 2.7 & 3.2 & 2.1\end{array}$

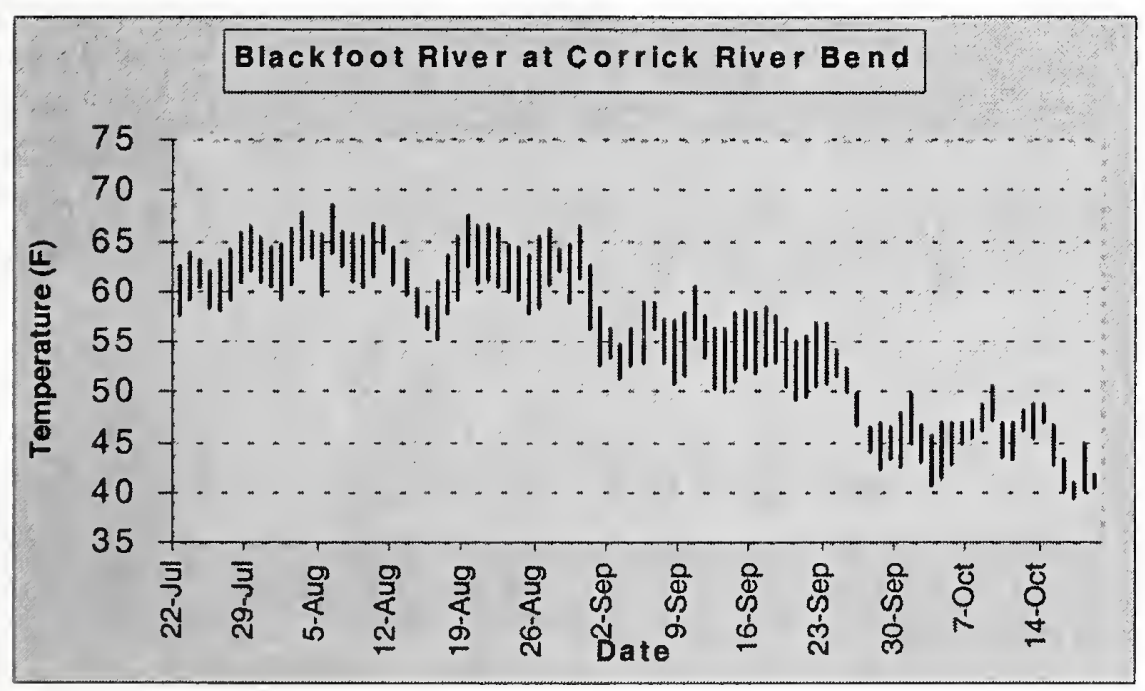

Month July August September October

$\begin{array}{lrrrr}\text { Monthly } & 62.1 & 62.6 & 52.9 & 45.1 \\ \begin{array}{l}\text { Mean } \\ \text { Monthly }\end{array} & 66.5 & 68.5 & 60.4 & 50.6 \\ \begin{array}{l}\text { Max } \\ \text { Monthly }\end{array} & 57.6 & 55.3 & 42.2 & 39.4 \\ \begin{array}{l}\text { Min } \\ \text { Stdev }\end{array} & 2.0 & 2.7 & 3.9 & 2.5\end{array}$




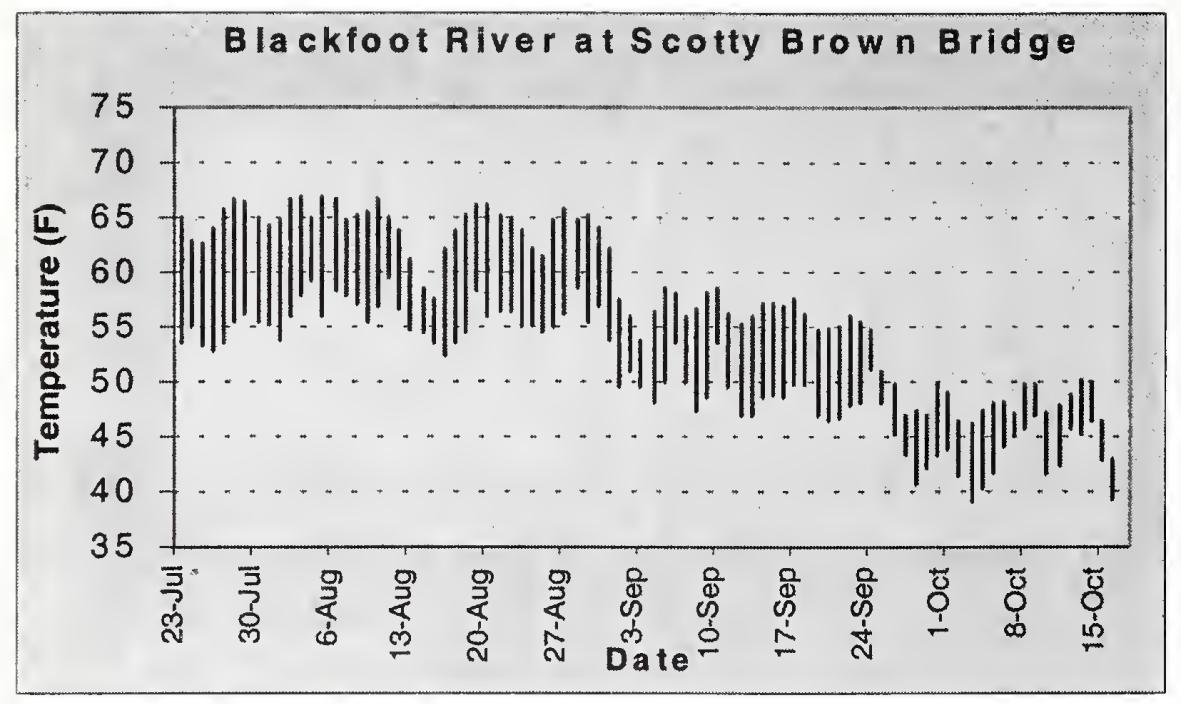

Month July August September October

$\begin{array}{llll}\text { Monthly } & 59.9 \quad 60.2 & 51.6 & 45.5\end{array}$

Mean

$\begin{array}{lllll}\text { Monthly } & 66.7 & 67.0 & 58.7 & 50.3\end{array}$

Max

$\begin{array}{lllll}\text { Montly } & 52.8 & 52.5 & 40.8 & 39.1\end{array}$

Min

$\begin{array}{lllll}\text { Stdev } & 3.8 & 3.5 & 3.9 & 2.6\end{array}$

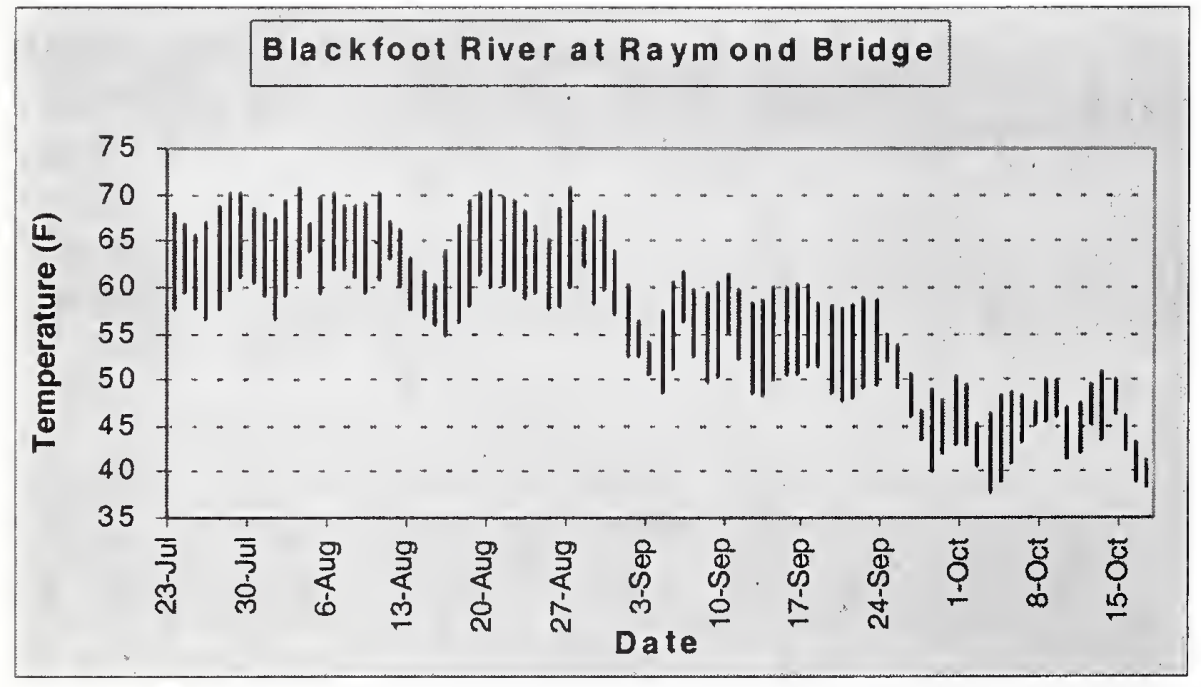

Month July August September October

$\begin{array}{lllll}\text { Monthly } & 63.3 & 63.3 & 53.1 & 44.9\end{array}$

Mean

$\begin{array}{lllll}\text { Monthly Max } & 70.2 & 70.8 & 61.8 & 50.8\end{array}$

$\begin{array}{llll}\text { Monthly Min } \quad 56.7 \quad 54.7 & 40.2 \quad 38.0\end{array}$

$\begin{array}{lllll}\text { Stdev } & 3.4 & 3.6 & 4.6 & 3.0\end{array}$




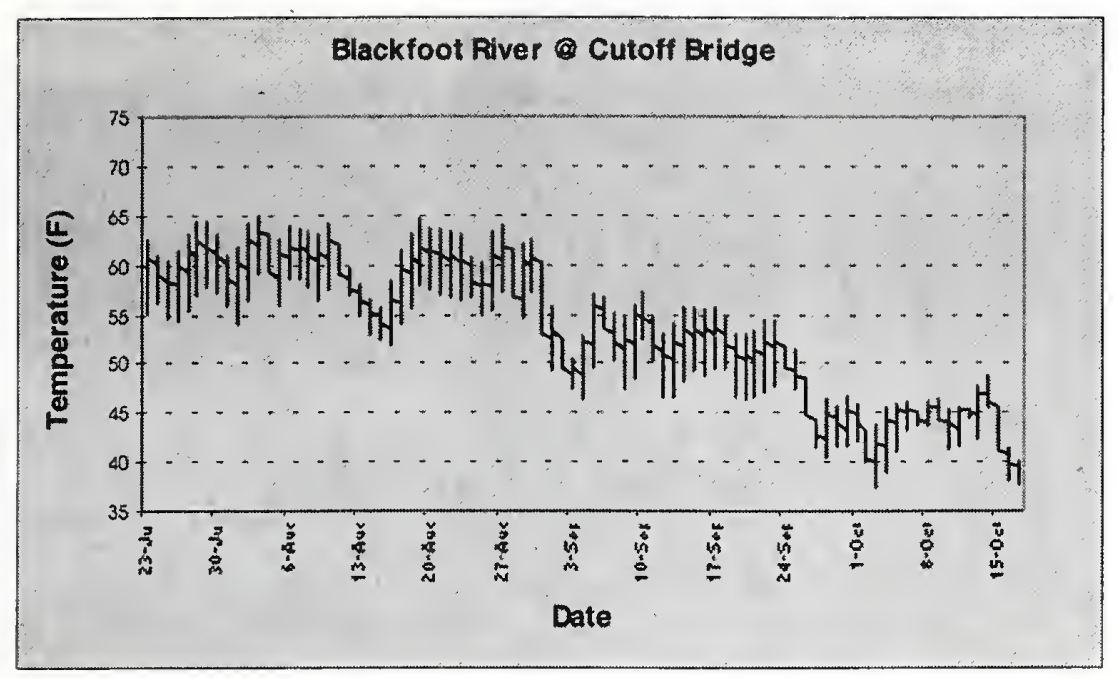

\begin{tabular}{lrrrr} 
Month & \multicolumn{2}{c}{ July } & \multicolumn{3}{c}{ September } & October \\
Monthy & 59.2 & 59.0 & 50.2 & 43.3 \\
Mean & & & & \\
Monthy Max & 64.4 & 65.0 & 57.3 & 48.9 \\
Monthly Min & 54.2 & 52.0 & 40.5 & 37.4 \\
Stdev & 2.5 & 2.8 & 3.7 & 2.5
\end{tabular}

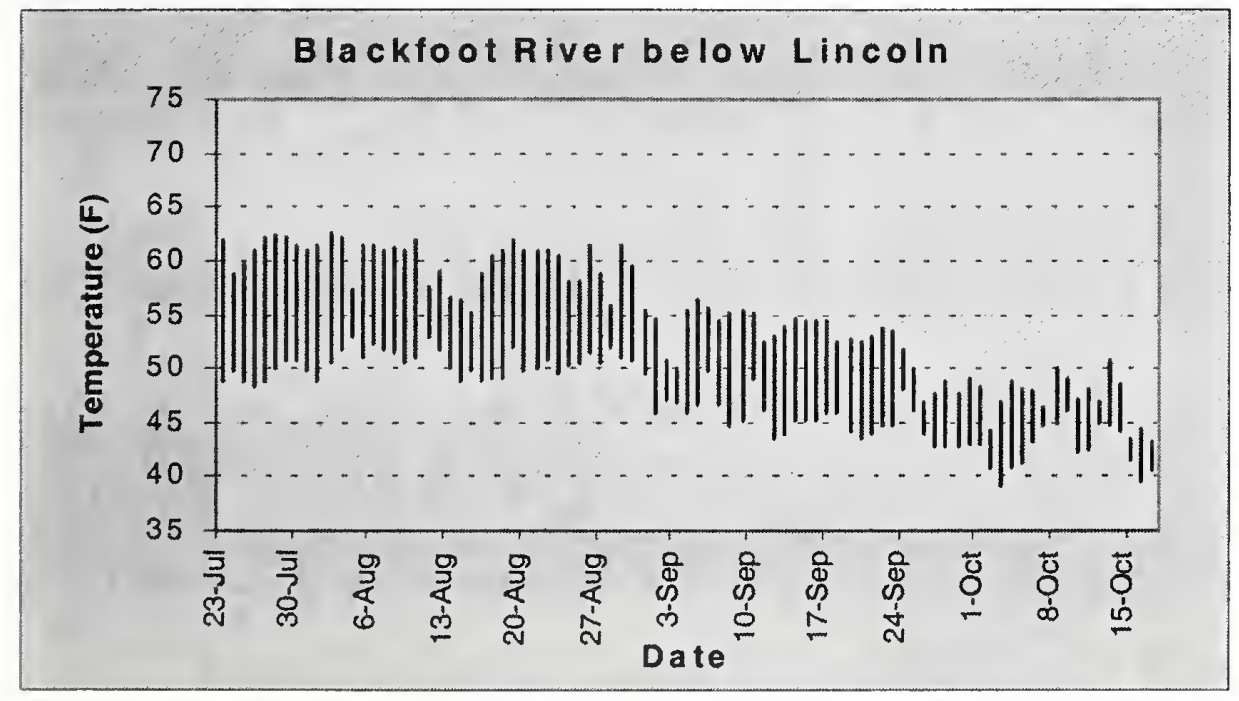

Month July August September October

$\begin{array}{lrrrr}\text { Monthly } & 55.2 & 54.9 & 48.8 & 44.8 \\ \begin{array}{l}\text { Mean } \\ \text { Monthly }\end{array} & 62.4 & 62.7 & 56.4 & 50.8 \\ \begin{array}{l}\text { Max } \\ \text { Monthly }\end{array} & 48.3 & 48.9 & 42.8 & 39.1 \\ \begin{array}{l}\text { Min } \\ \text { Stdev }\end{array} & 4.1 & 3.5 & 3.3 & 2.6\end{array}$




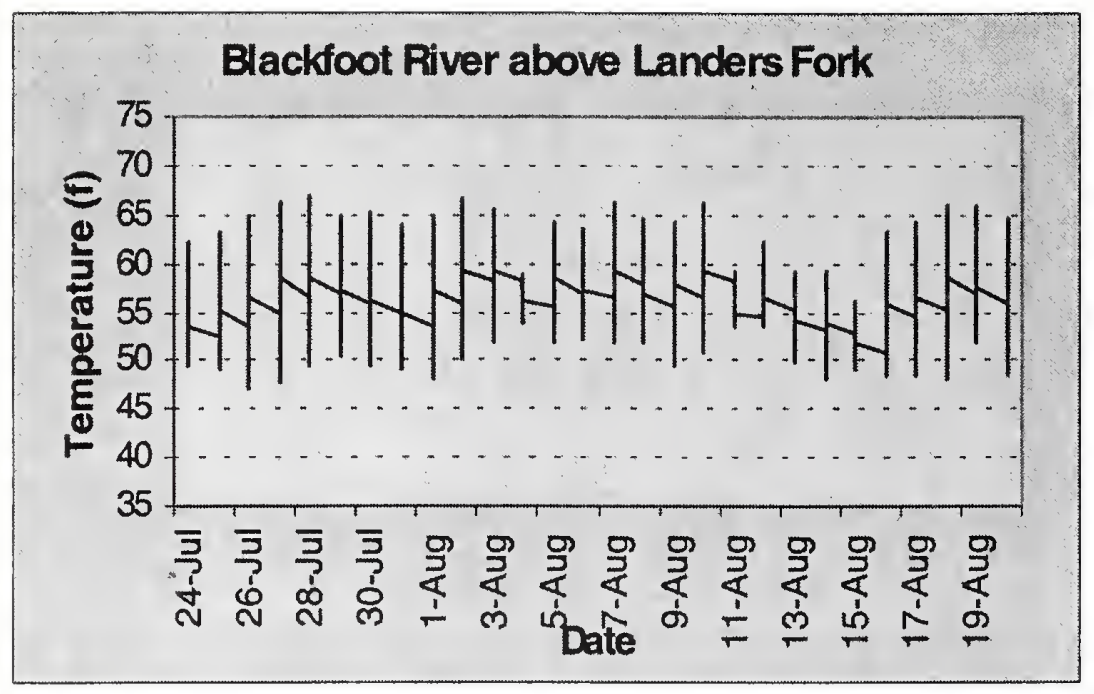

\begin{tabular}{lrr} 
Month & July & \multicolumn{2}{c}{ August } \\
Monthly Meam & 56.0 & 56.3 \\
Monthly Max & 67.0 & 66.7 \\
Monthly Min & 47.2 & 48.0 \\
Stdev & 5.5 & 4.8
\end{tabular}




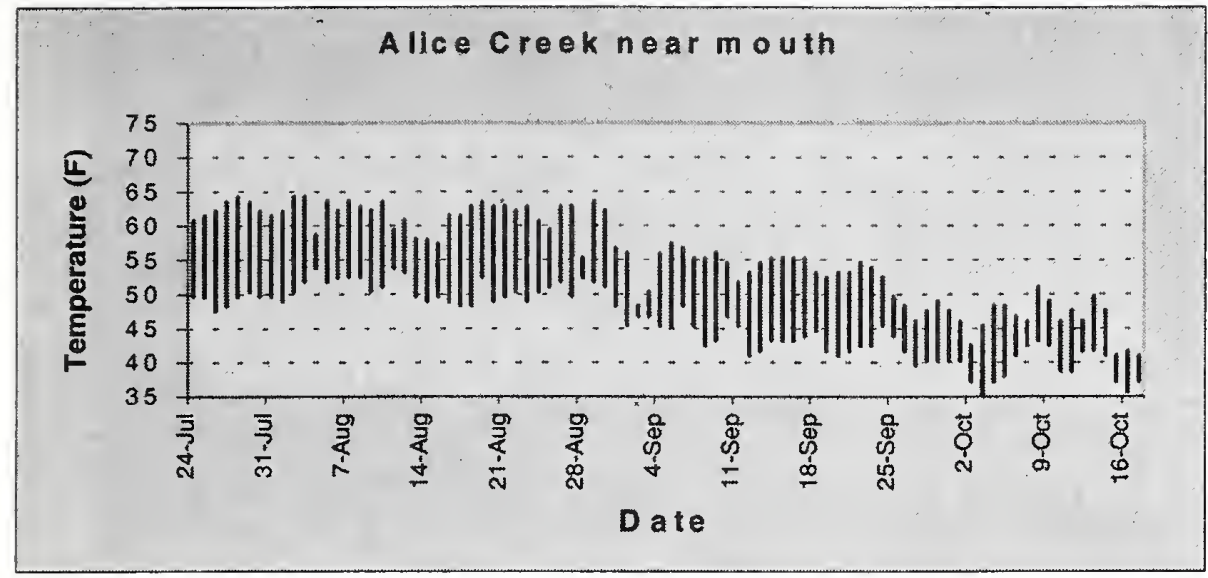

Month July August September October

$\begin{array}{lllll}\text { Monthly } & 55.1 & 55.4 & 47.4 & 42.3\end{array}$

Mean

$\begin{array}{lllll}\text { Monthly } & 64.2 & 57.7 & 57.4 & 51.1\end{array}$

Max

$\begin{array}{lllll}\text { Monthly } & 47.6 & 48.3 & 39.5 & 34.9\end{array}$

Min

Stdev

4.6

4.0

$4.1 \quad 3.4$

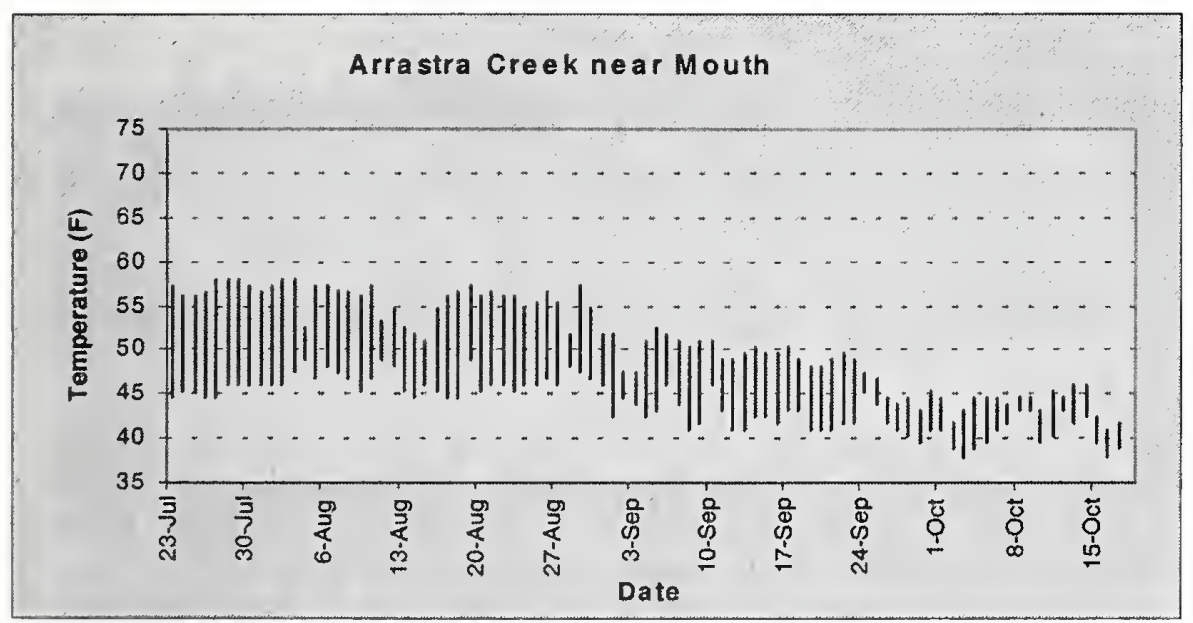

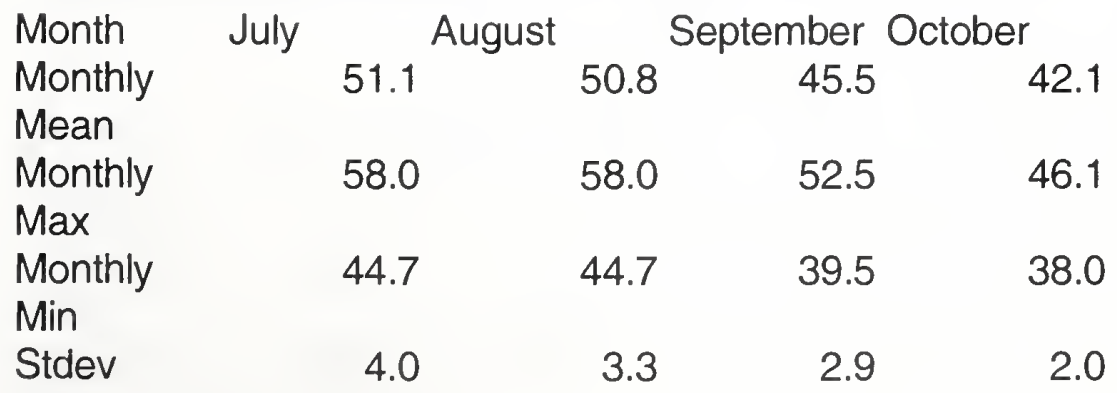




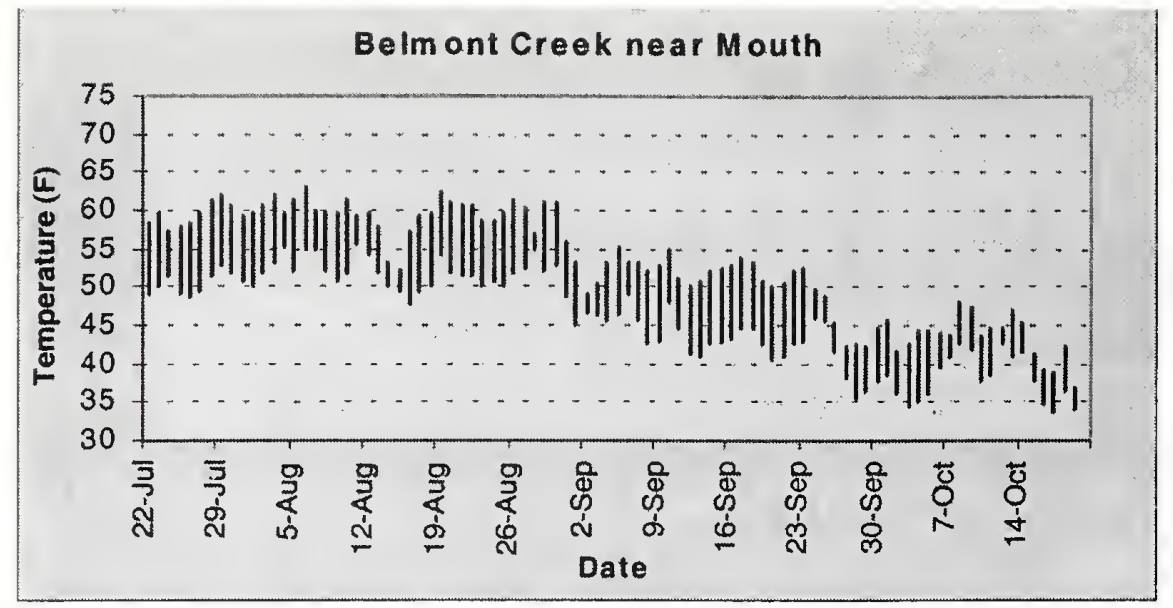

Month July August September October

$\begin{array}{lllll}\text { Monthly } & 56.0 & 56.5 & 47.2 & 42.2\end{array}$

Mean

$\begin{array}{lllll}\text { Monthly } \quad 63.5 & 64.9 & 57.4 & & \end{array}$

Max

$\begin{array}{lllll}\text { Monthly } & 48.3 & 47.6 & 38.7 & 33.3\end{array}$

Min

Stdev

4.2

4.1

$\begin{array}{ll}4.5 & 3.8\end{array}$

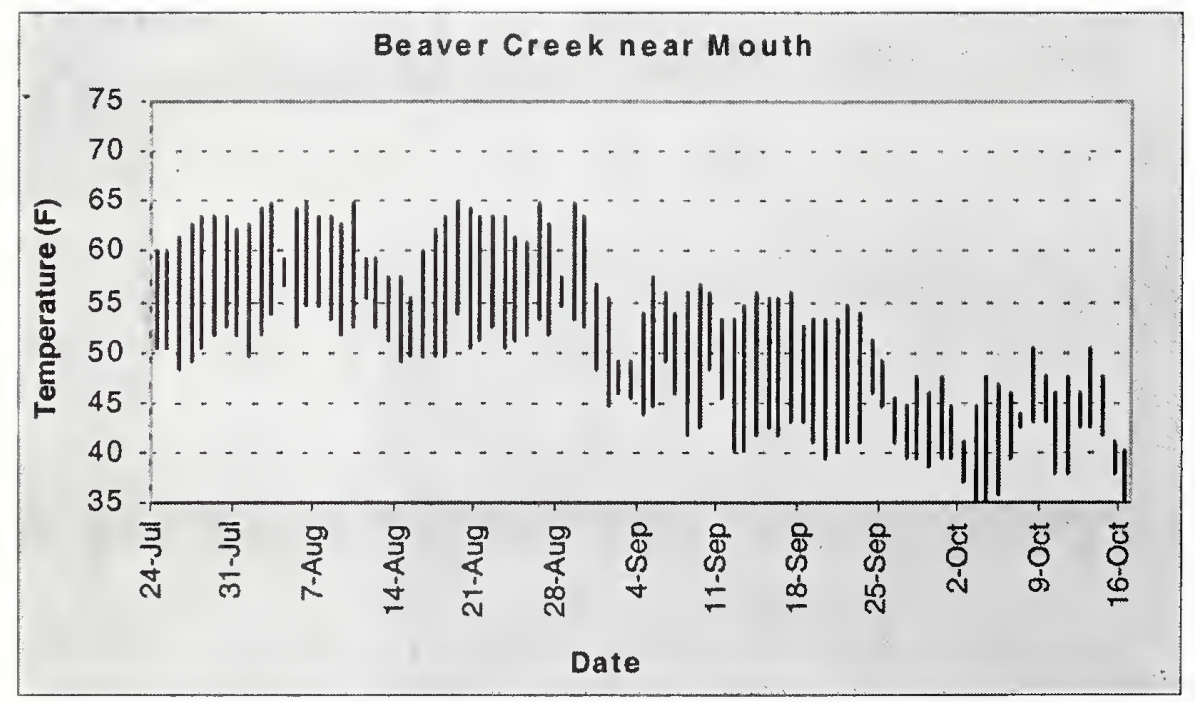

Month July August September October

$\begin{array}{lllll}\text { Monthly } & 54.5 & 55.2 & 46.4 & 40.8\end{array}$

Mean

$\begin{array}{lllll}\text { Monthly } & 62.1 & 63.2 & 55.3 & 48.0\end{array}$

Max

$\begin{array}{lllll}\text { Monthly } & 48.9 & 47.8 & 35.4 & 33.7\end{array}$

Min

Stdev

$\begin{array}{llll}3.1 & 3.1 & 4.1 & 3.4\end{array}$




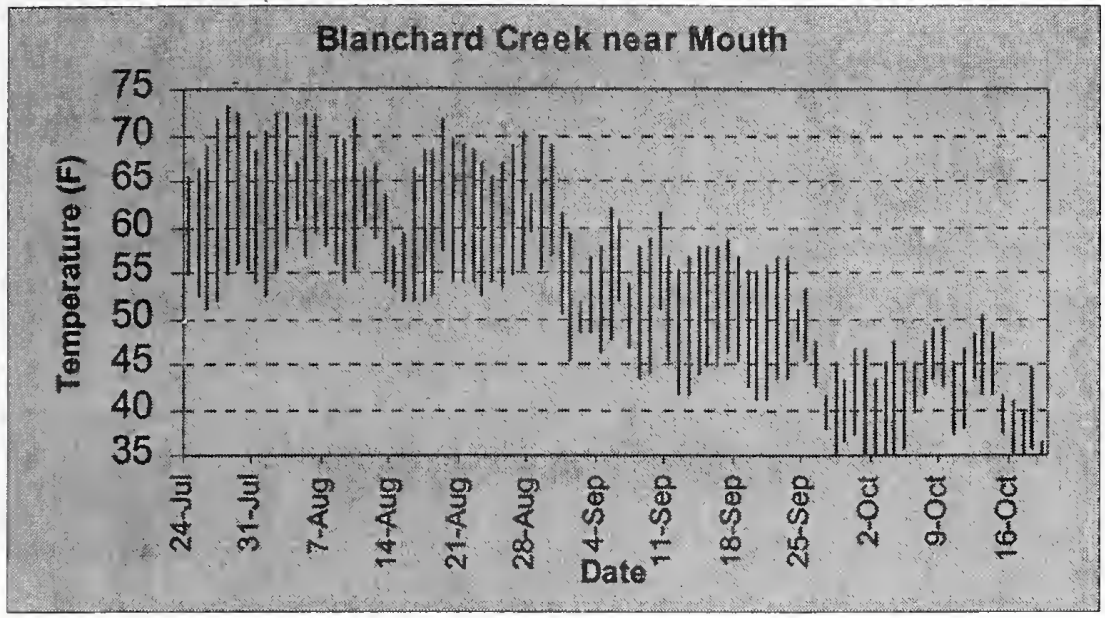

\begin{tabular}{|c|c|c|c|c|}
\hline Month & July & August & September & October \\
\hline $\begin{array}{l}\text { Monthly } \\
\text { Mean }\end{array}$ & 61.2 & 61.2 & 49.4 & 41.4 \\
\hline $\begin{array}{l}\text { Monthly } \\
\text { Max }\end{array}$ & 73.2 & 72.5 & 62.2 & 50.4 \\
\hline $\begin{array}{l}\text { Monthly } \\
\text { Min }\end{array}$ & 51.1 & 49.7 & 34.9 & 32 \\
\hline Stdev & 5.8 & 5.1 & 5.8 & 4 \\
\hline
\end{tabular}

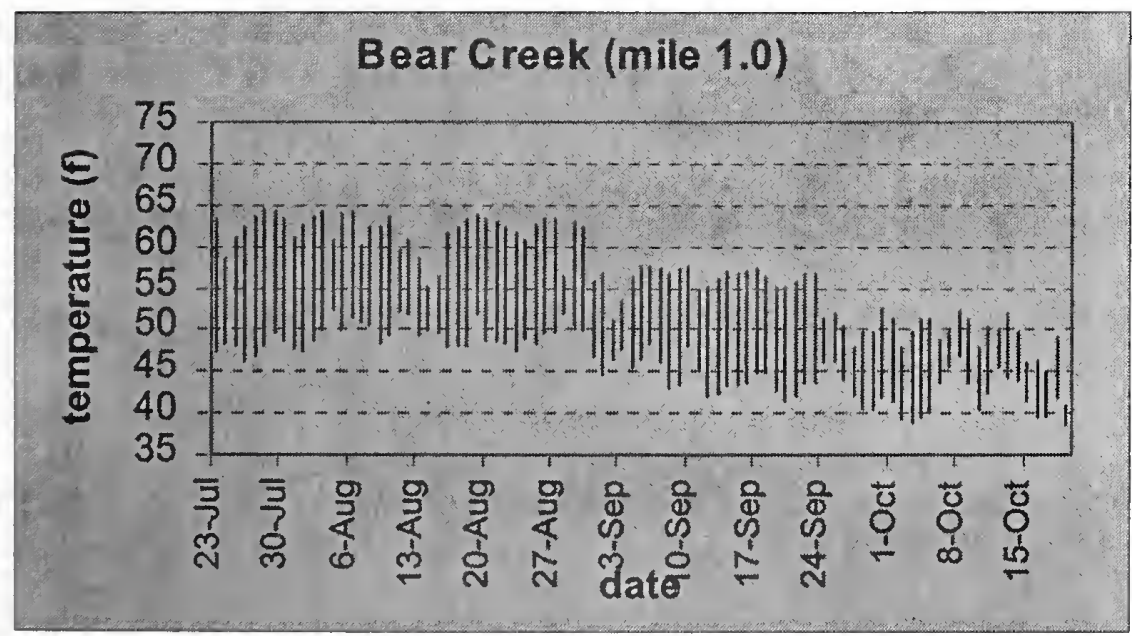

\begin{tabular}{|c|c|c|c|c|}
\hline Month & July & August & September & October \\
\hline $\begin{array}{l}\text { Monthly } \\
\text { mean }\end{array}$ & 53.8 & 54.3 & 48.5 & 45.1 \\
\hline $\begin{array}{l}\text { Monthly } \\
\text { max }\end{array}$ & 64.7 & 64.4 & 57.8 & 52.2 \\
\hline $\begin{array}{l}\text { Monthly } \\
\text { min }\end{array}$ & 46.1 & 46.7 & 40.5 & 38.5 \\
\hline
\end{tabular}




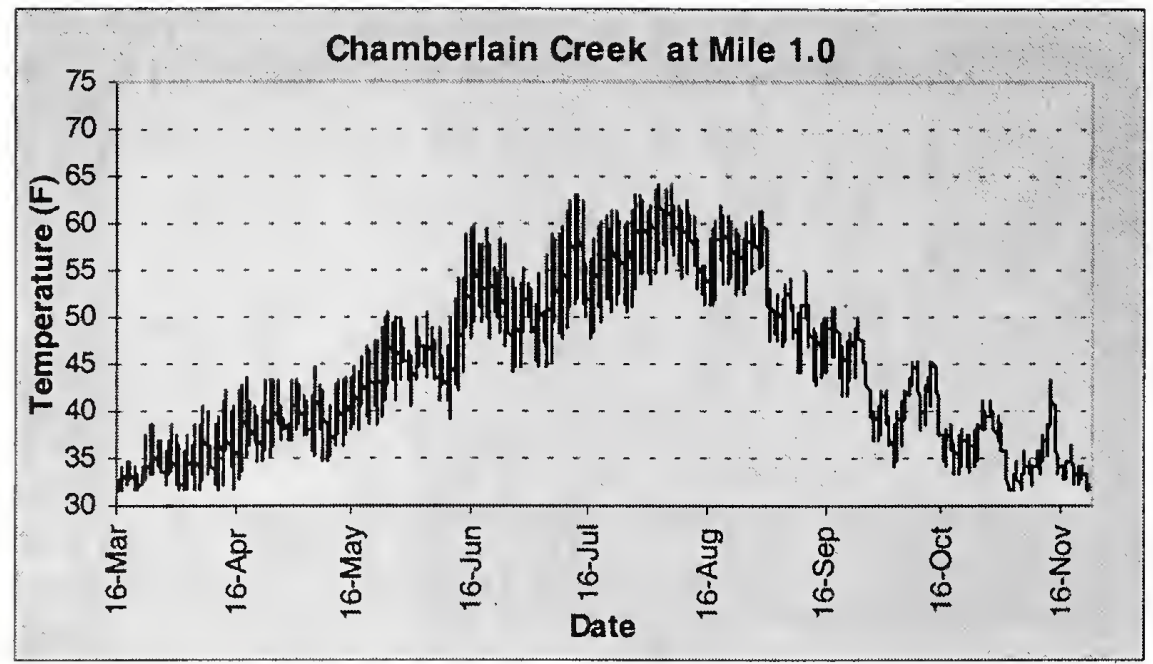

Month March April May June July August September October November

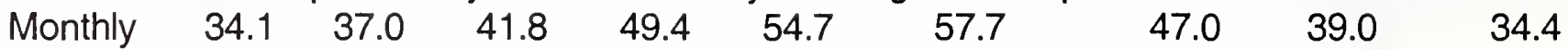
Mean

$\begin{array}{llllllll}\text { Monthly } & 38.5 & 43.7 & 50.5 & 59.8 & 63.0 & 64.1 & 54.6\end{array}$

Max

Monthly

Min

Stdev

$\begin{array}{llll}3.0 & 3.6 & 4.4 & 4.4\end{array}$

4.4

2.9

3.9

3.0

43.2

$36.9 \quad 33.2$

31.6

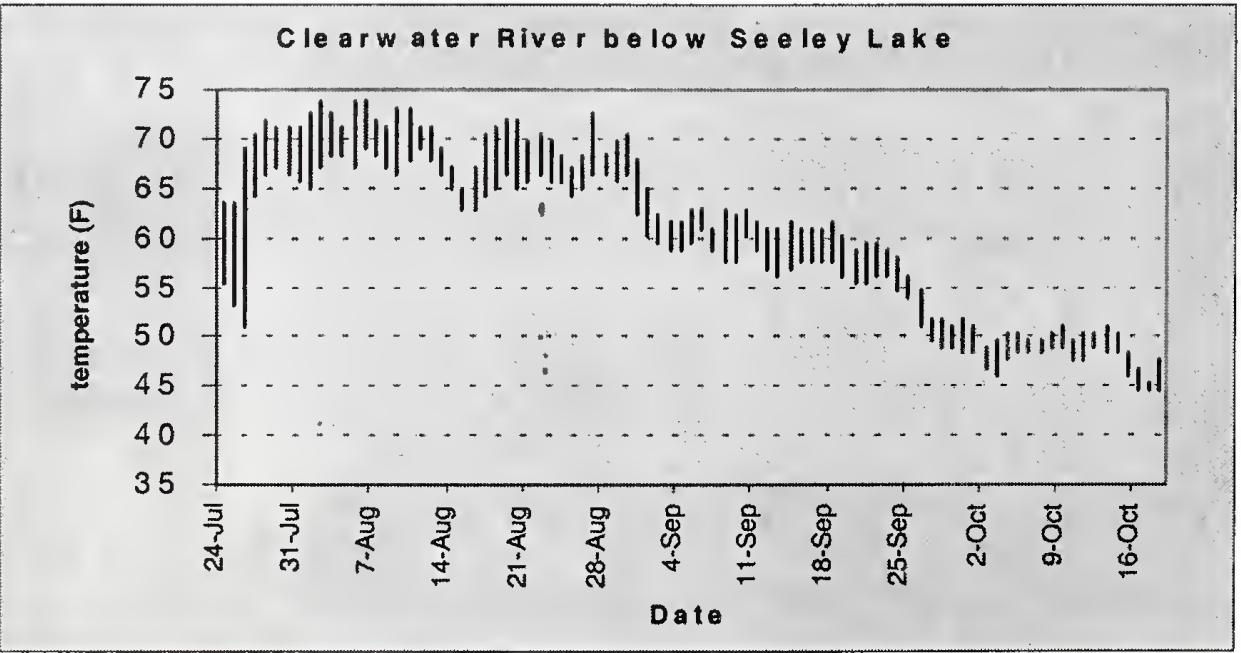

Month July August September October

$\begin{array}{lllll}\text { Monthly } & 65.5 & 68.1 & 57.8 & 48.3\end{array}$

Mean

Monthly

$\begin{array}{lll}71.8 & 73.9 & 64.9\end{array}$

51.1

Max

Monthly

$51.1 \quad 62.2$

48.3

44.7

Min

Stdev 


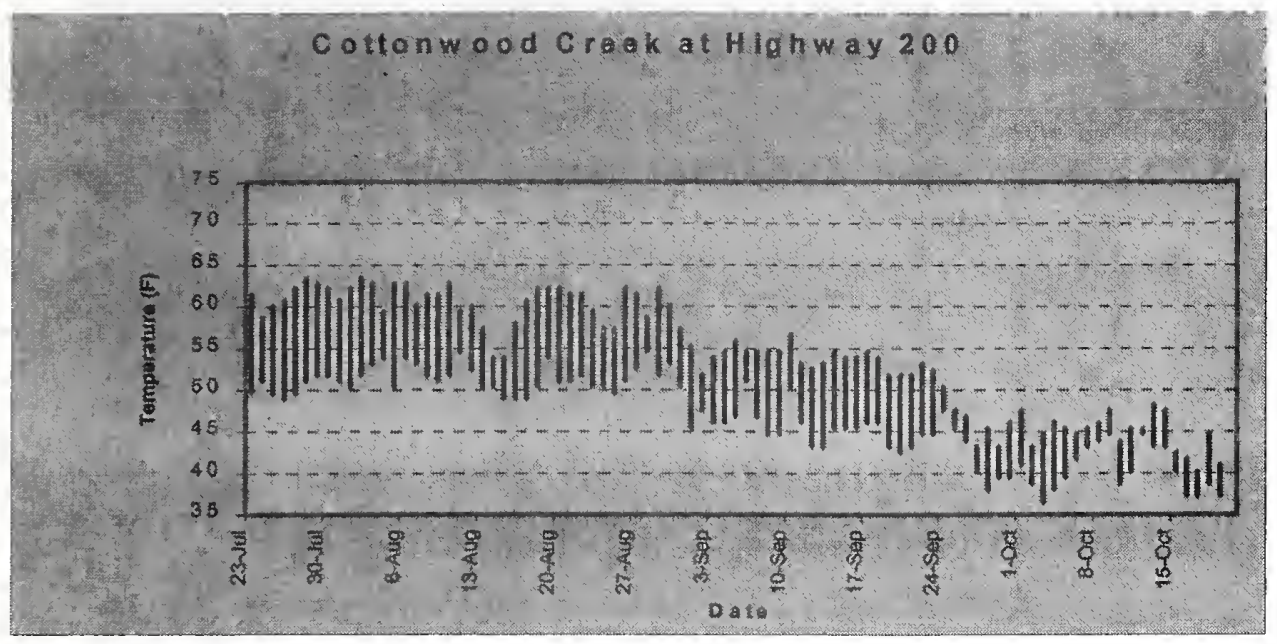

Month July August September October

$\begin{array}{lllll}\text { Monthly } & 56.0 & 55.8 & 48.5 & 42.9\end{array}$

Mean

$\begin{array}{lllll}\text { Monthly } & 63.5 & 63.5 & 56.7 & 48.3\end{array}$

Max

$\begin{array}{lllll}\text { Monthly } & 49.0 & 49.0 & 38.0 & 36.4\end{array}$

Min

Stdev

$3.9 \quad 3.5$

$\begin{array}{ll}4.0 & 2.7\end{array}$

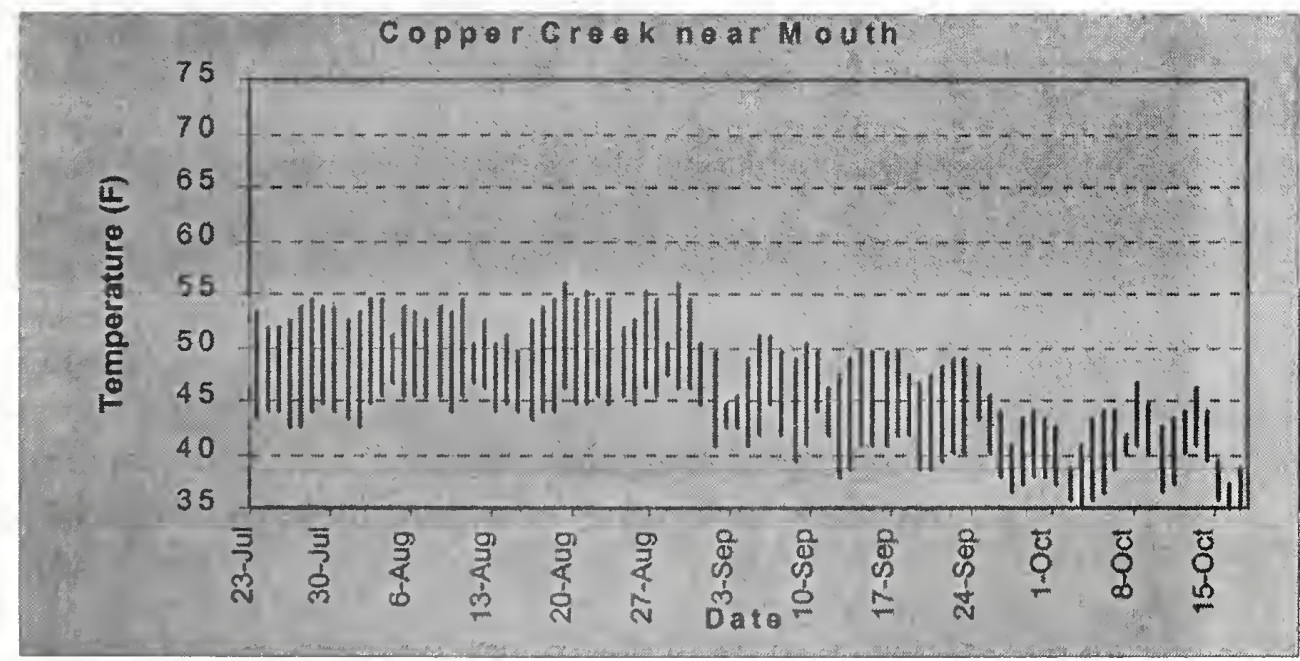

Month July August September October

$\begin{array}{lllll}\text { Monthly } & 47.9 & 48.8 & 43.6 & 39.7\end{array}$

Mean

$\begin{array}{lllll}\text { Monthly } & 54.6 & 56.0 & 51.1 & 46.8\end{array}$

Max

$\begin{array}{lllll}\text { Monthly } & 42.5 & 42.5 & 36.4 & 32.5\end{array}$

Min

Stdev

$3.4 \quad 3.0$

3.2

3.1 


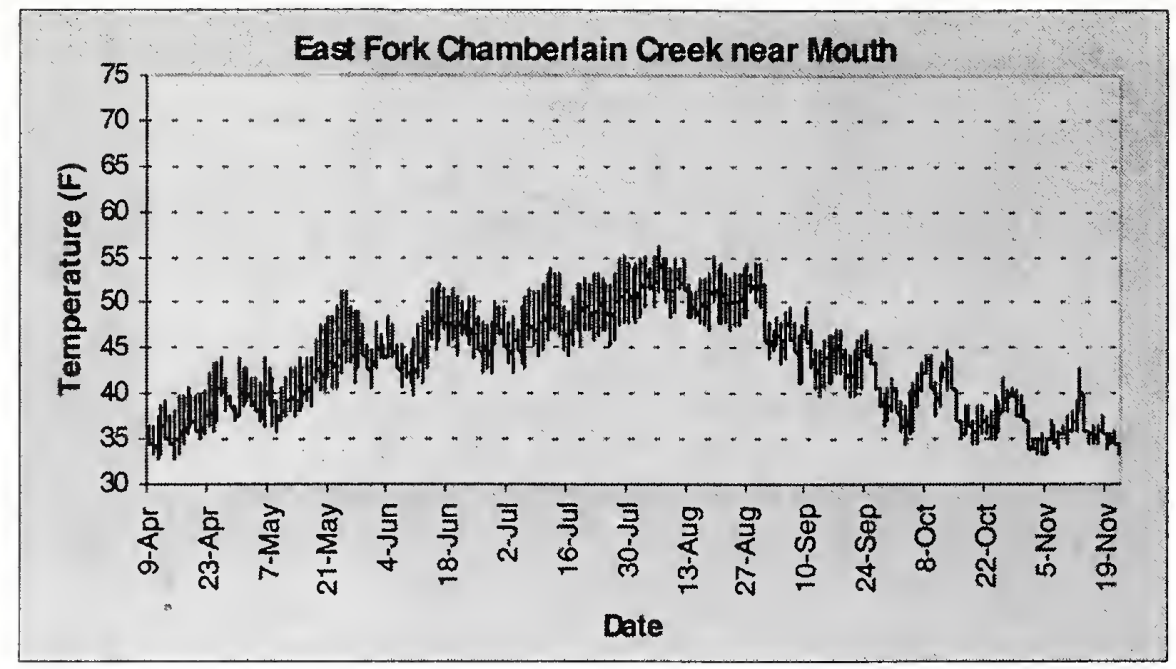

Month April May June July August September October November $\begin{array}{lllllllll}\text { Monthly } & 37.6 & 42.1 & 46.2 & 48.7 & 51.3 & 43.9 & 38.9 & 35.7\end{array}$ Mean

$\begin{array}{lrrrrrrrr}\text { Monthly } & 43.9 & 51.1 & 52.1 & 55.3 & 56.3 & 49.6 & 44.9 & 42.8 \\ \begin{array}{l}\text { Max } \\ \text { Monthly }\end{array} & 32.8 & 36.0 & 39.7 & 42.3 & 45.4 & 36.5 & 34.4 & 33.3 \\ \begin{array}{l}\text { Min } \\ \text { stdev }\end{array} & 2.4 & 3.3 & 2.5 & 2.6 & 2.0 & 2.8 & 2.5 & 1.7\end{array}$

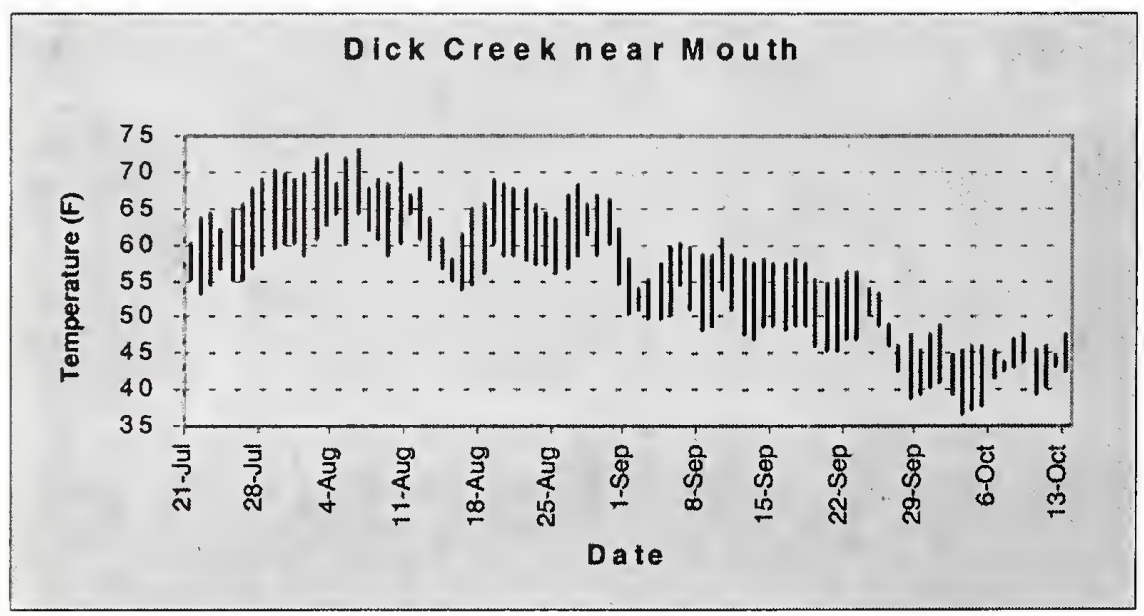

Month July August September October

$\begin{array}{lrrrr}\text { Monthly } & 61.6 & 62.9 & 51.5 & 43.2 \\ \begin{array}{l}\text { Mean } \\ \text { Monthly }\end{array} & 70.4 & 73.2 & 60.8 & 49.0 \\ \begin{array}{l}\text { Max } \\ \text { Monthly }\end{array} & 53.2 & 53.9 & 38.7 & 36.4 \\ \begin{array}{l}\text { Min } \\ \text { Stdev }\end{array} & 4.1 & 4.0 & 4.6 & 2.4\end{array}$




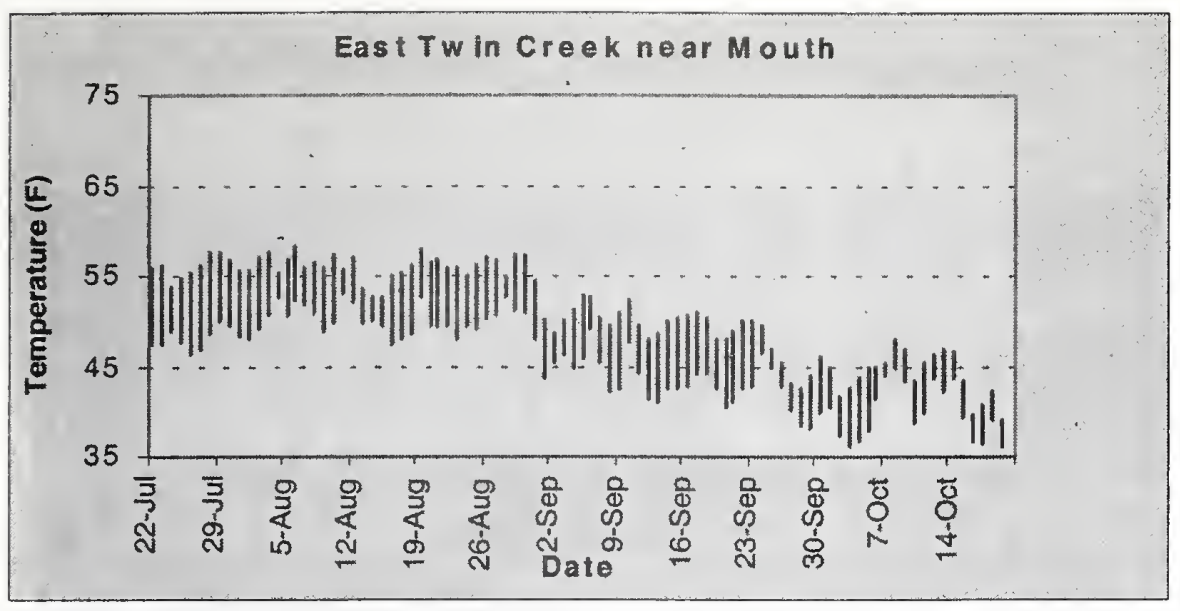

Month July August September October

$\begin{array}{lllll}\text { Monthly } & 52.2 & 53.2 & 46.3 & 42.3\end{array}$

Mean

$\begin{array}{lllll}\text { Monthly } & 57.6 & 58.1 & 52.6 & 48.1\end{array}$

Max

$\begin{array}{lllll}\text { Monthly } & 46.4 & 47.0 & 38.3 & 36.3\end{array}$

Min

$\begin{array}{lllll}\text { Stdev } & 3.0 & 2.5 & 3.2 & 3.0\end{array}$

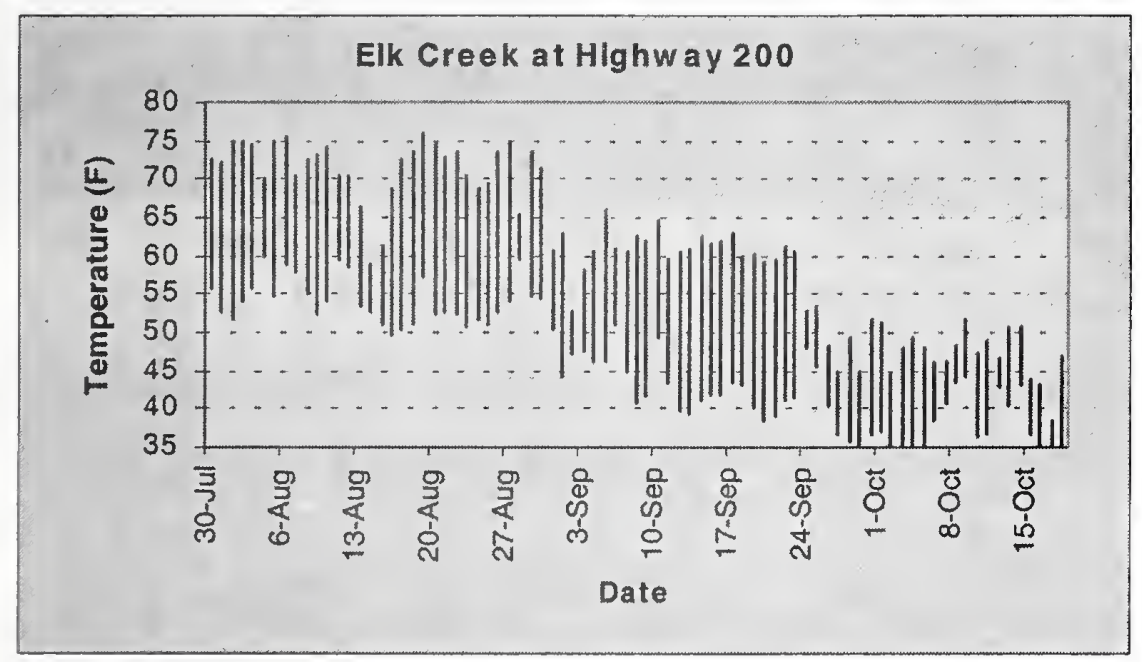

Month July August September October

$\begin{array}{lllll}\text { Monthly } & 64.1 & 62.0 & 49.8 & 41.9\end{array}$

Mean

$\begin{array}{lllll}\text { Monthly } & 72.7 & 75.8 & 65.9 & 51.7\end{array}$

Max

$\begin{array}{lllll}\text { Monthly } & 52.9 & 49.8 & 34.6 & 32.0\end{array}$

Min

Stdev

6.6

6.7

7.0

4.8 


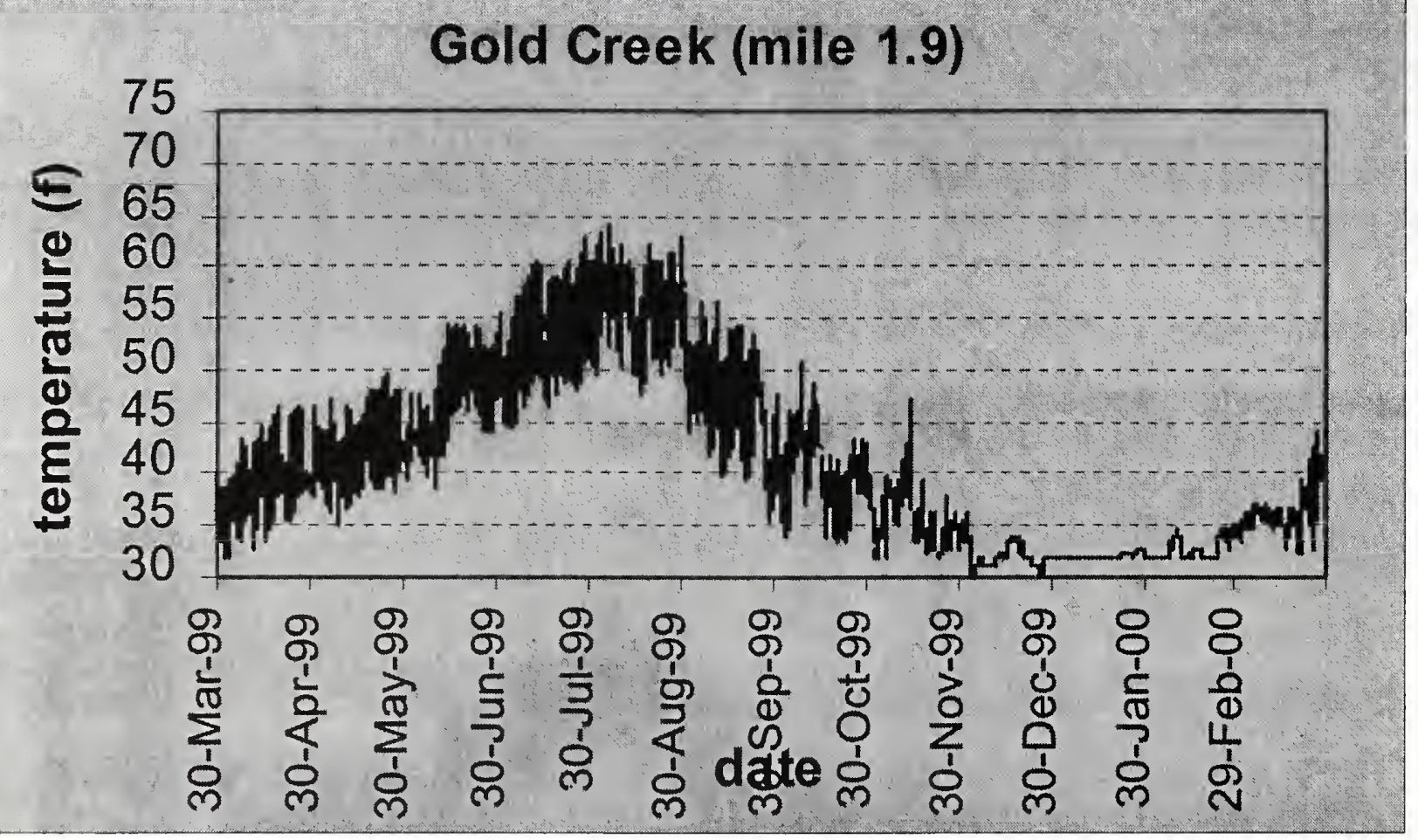

Month March April May June July August Sept Oct Nov

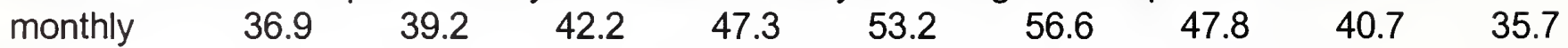
Mean

Monthly

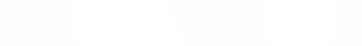

Max

Monthly

Min

Stdev $40.4 \quad 46.6$

$49.7 \quad 55.4$

62.8

63.9

56.5

50.8

47.1

$33.4 \quad 31.8$

$35.1 \quad 38.8$

44.5

47.7

35.6

33.4

31.8

$\begin{array}{llll}1.8 & 3.2 & 2.9 & 3.8\end{array}$

4.3

3.4

4.5

3.6

2.8

\begin{tabular}{lcccc} 
Month & Dec Jan & \multicolumn{2}{c}{ Feb } & \multicolumn{2}{c}{ March } \\
monthly & 32.0 & 32.0 & 32.6 & 36.3 \\
Mean & & & & \\
Monthly & 36.1 & 32.9 & 35.1 & 44.0 \\
Max & & & & \\
$\begin{array}{l}\text { Monthly } \\
\text { Min }\end{array}$ & 29.1 & 31.8 & 31.8 & 32.4 \\
Stdev & 1.1 & 0.3 & 1.0 & 2.0
\end{tabular}




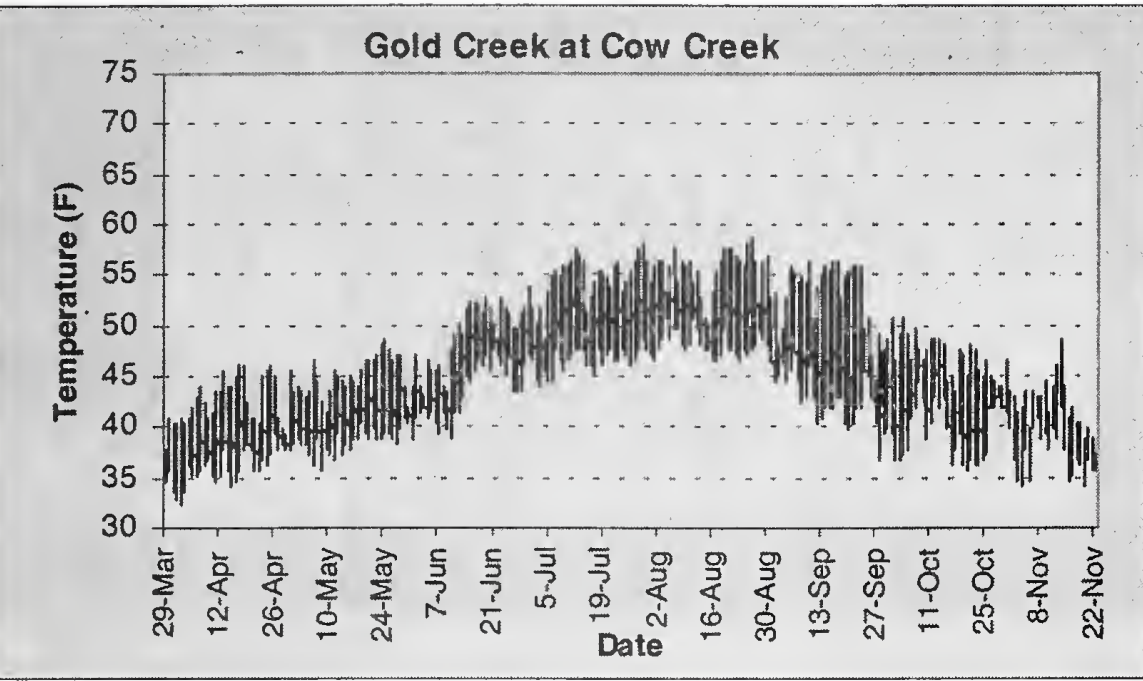

Month March April May June July August September October November

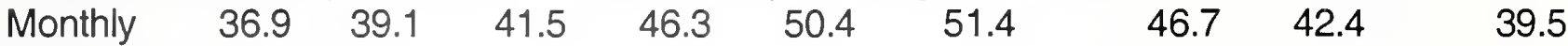
Mean

Monthly

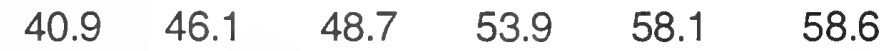

$56.5 \quad 50.8$

48.7

Max

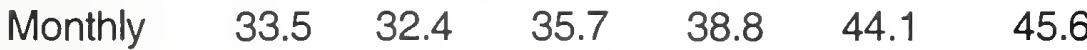

$36.7 \quad 35.7$

34.1

Min

Stdev

$\begin{array}{lllll}1.7 & 2.8 & 2.6 & 3.4 & 3.2\end{array}$

2.7

4.1

3.2

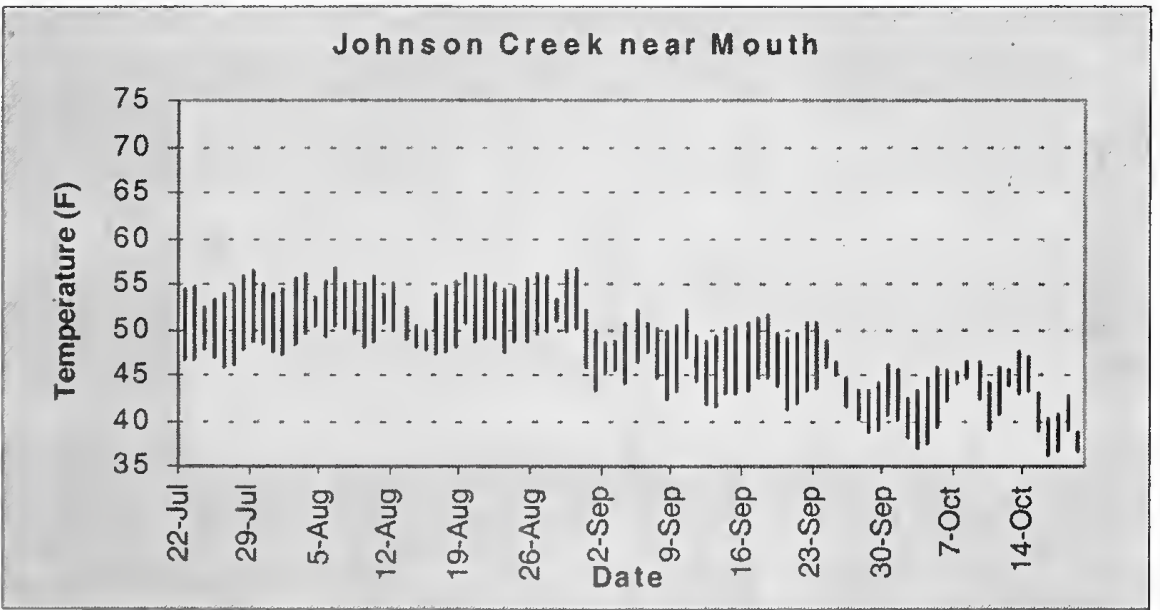

Month July August September October

$\begin{array}{lllll}\text { Monthly } & 50.3 & 51.5 & 46.0 & 42.4\end{array}$

Mean

Monthly

$56.4 \quad 56.7$

52.2

47.5

Max

Monthly

45.8

45.3

38.8

36.3

Min

Stdev

2.6

2.3

2.9

2.8 


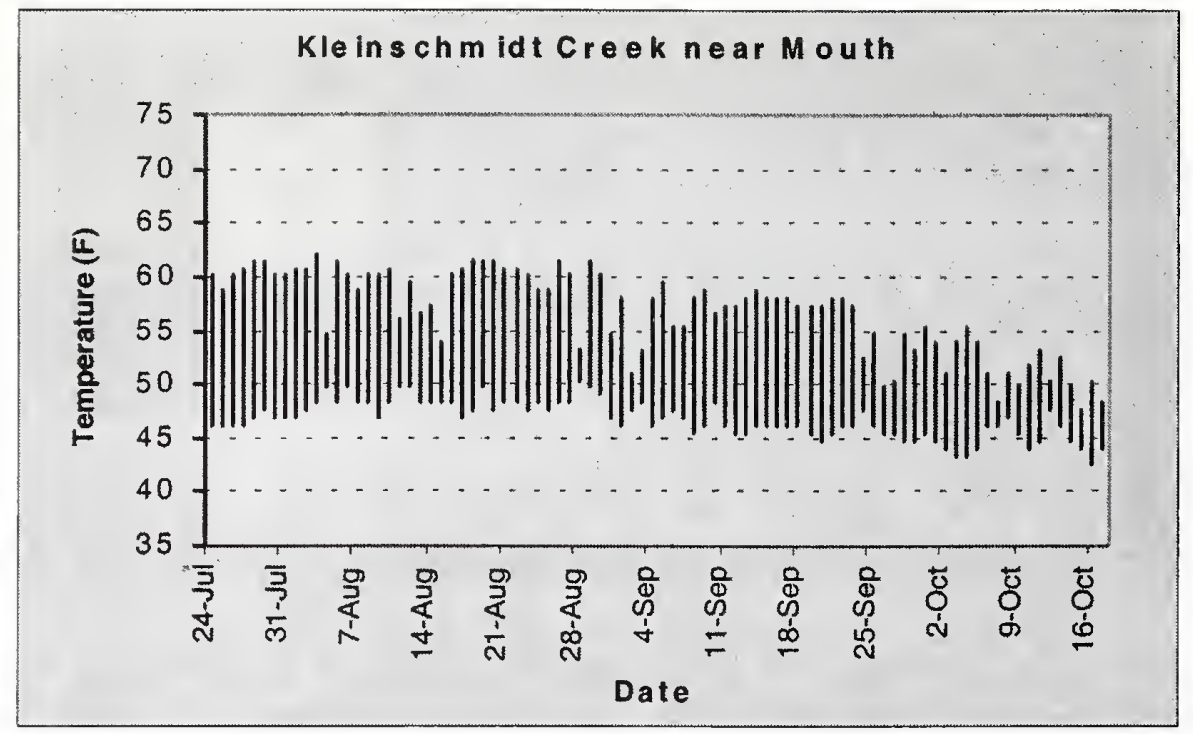

Month July August September October

$\begin{array}{lllll}\text { Monthly } & 52.4 & 52.8 & 50.1 & 47.4\end{array}$

Mean

$\begin{array}{lllll}\text { Monthly } & 61.5 & 62.2 & 59.4 & 55.3\end{array}$

Max

$\begin{array}{lllll}\text { Monthly } & 46.1 & 46.8 & 44.7 & 42.5\end{array}$

Min

$\begin{array}{lllll}\text { Stdev } & 5.0 & 4.0 & 3.8 & 2.6\end{array}$

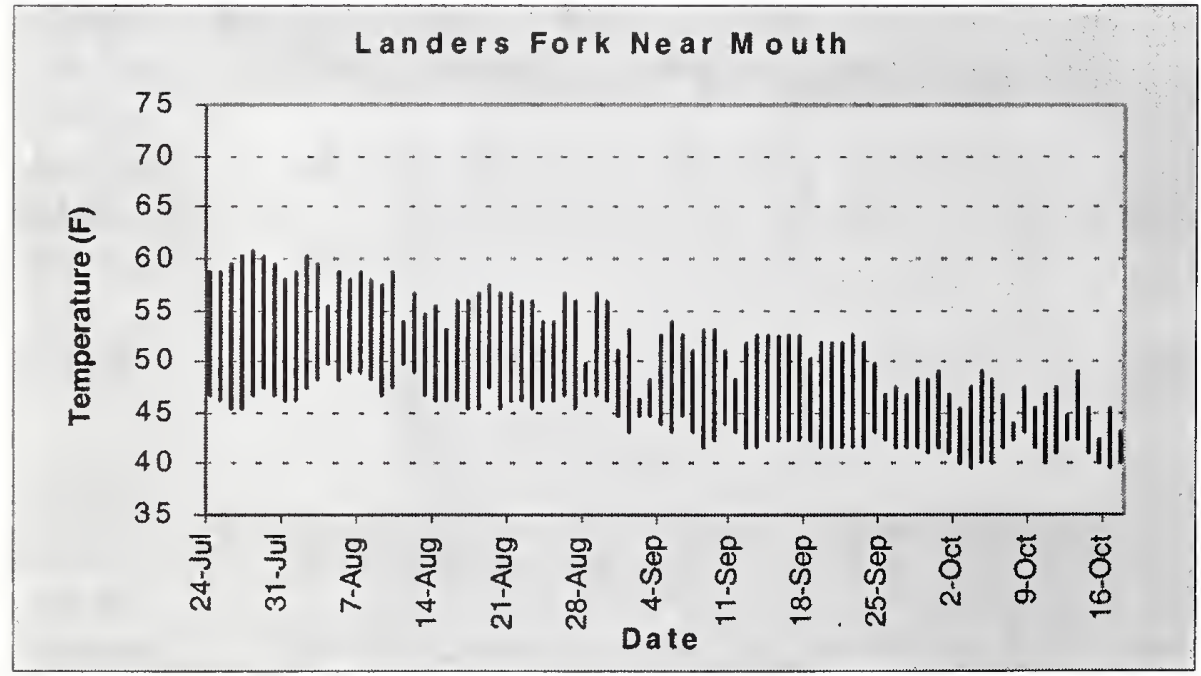

Month July August September October

$\begin{array}{lllll}\text { Monthly } & 52.0 & 50.7 & 45.6 & 42.9\end{array}$

Mean

$\begin{array}{lllll}\text { Monthly } & 60.8 & 60.1 & 53.9 & 49.0\end{array}$

Max

$\begin{array}{lllll}\text { Monthly } & 45.4 & 43.9 & 41.0 & 39.5\end{array}$

Min

Stdev

4.5

3.6

3.2

2.2 


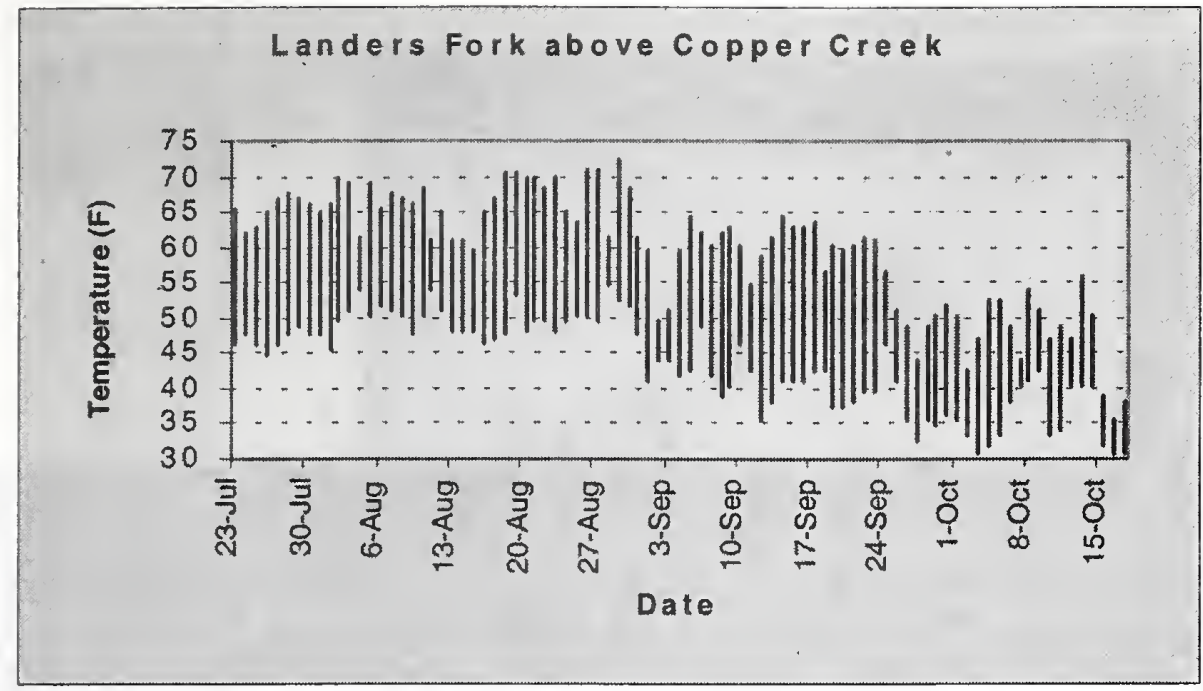

Month July August September October

$\begin{array}{lllll}\text { Monthly } & 55.6 & 57.5 & 47.9 & 40.6\end{array}$

Mean

$\begin{array}{lllll}\text { Monthly } & 67.7 & 72.5 & 64.2 & 56.0\end{array}$

Max

$\begin{array}{lllll}\text { Monthly } & 44.7 & 45.4 & 32.5 & 30.9\end{array}$

Min

$\begin{array}{lllll}\text { Stdev } & 6.5 & 6.2 & 7.3 & 6.2\end{array}$

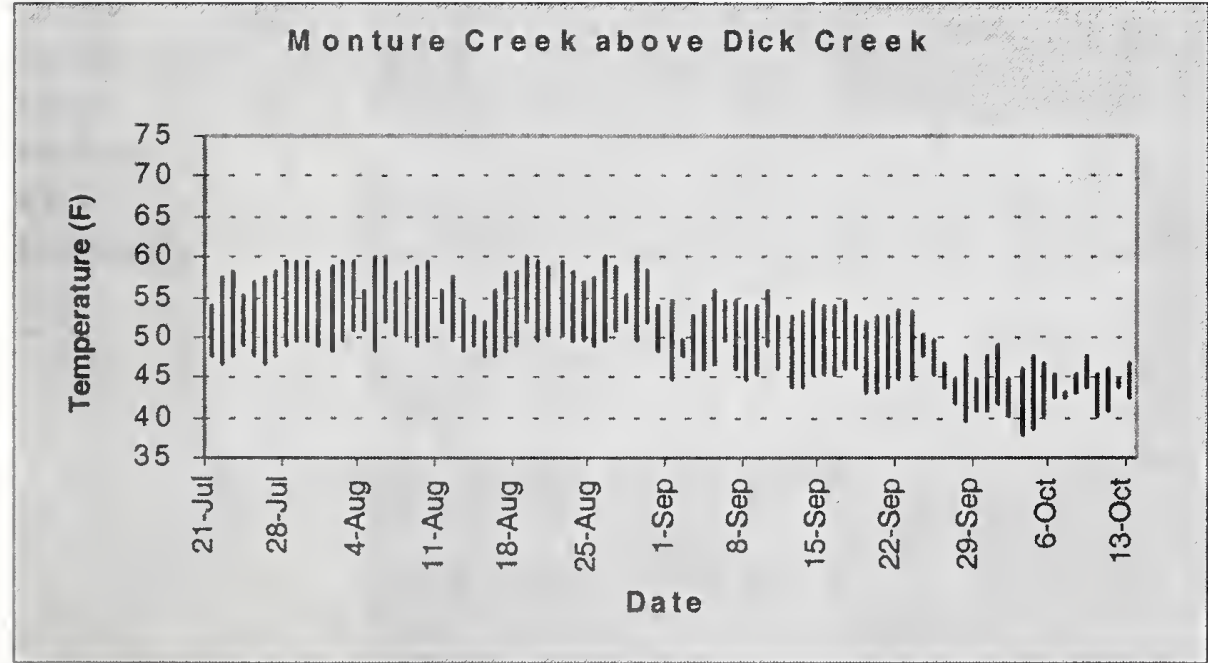

Month July August September October

$\begin{array}{lllll}\text { Monthly } & 53.2 & 53.4 & 48.2 & 43.6\end{array}$

Mean

$\begin{array}{lllll}\text { Monthly } & 59.4 & 60.1 & 56.0 & 49.0\end{array}$

Max

$\begin{array}{lllll}\text { Montly } & 46.8 & 44.7 & 39.5 & 38.0\end{array}$

Min

Sdev 


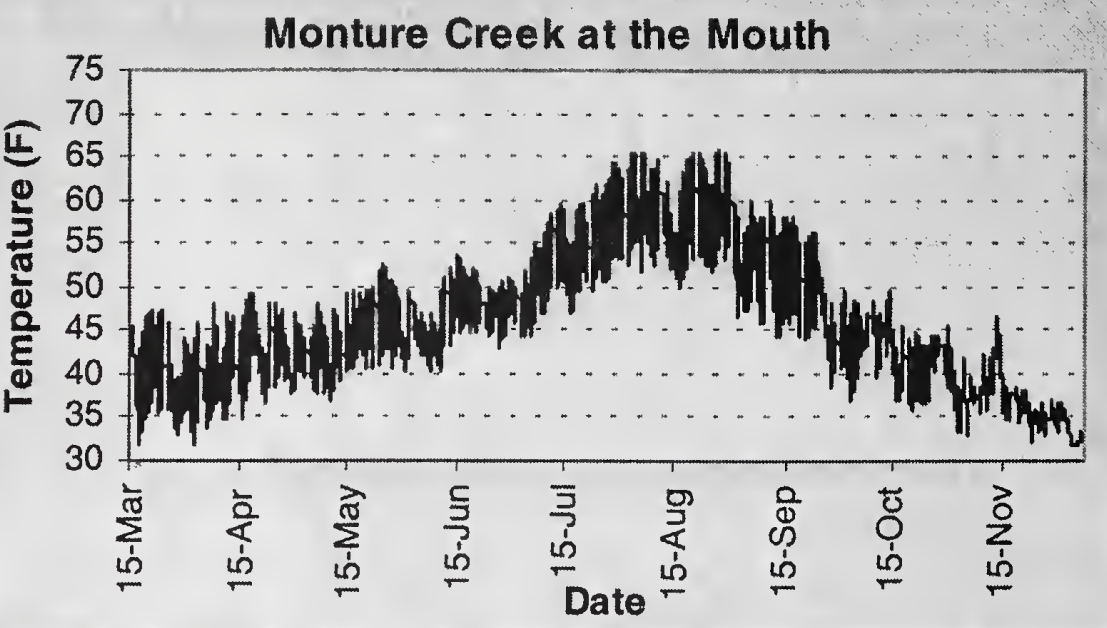

Month March April May June July August September October November $\begin{array}{llllllllll}\text { Monthly } & 39.4 & 41.2 & 44.1 & 46.7 & 53.5 & 57.8 & 50.3 & 42.5 & 37.1\end{array}$ Mean

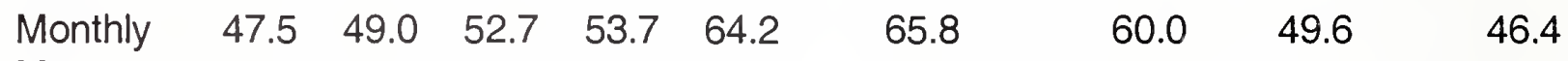
Max

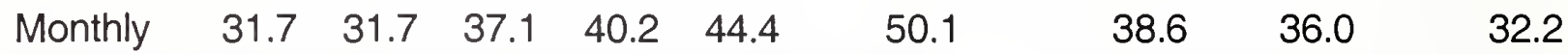
Min stdev $\begin{array}{lllll}3.6 & 3.6 & 3.2 & 2.8 & 4.5\end{array}$

3.9

$4.5 \quad 2.9$

2.6

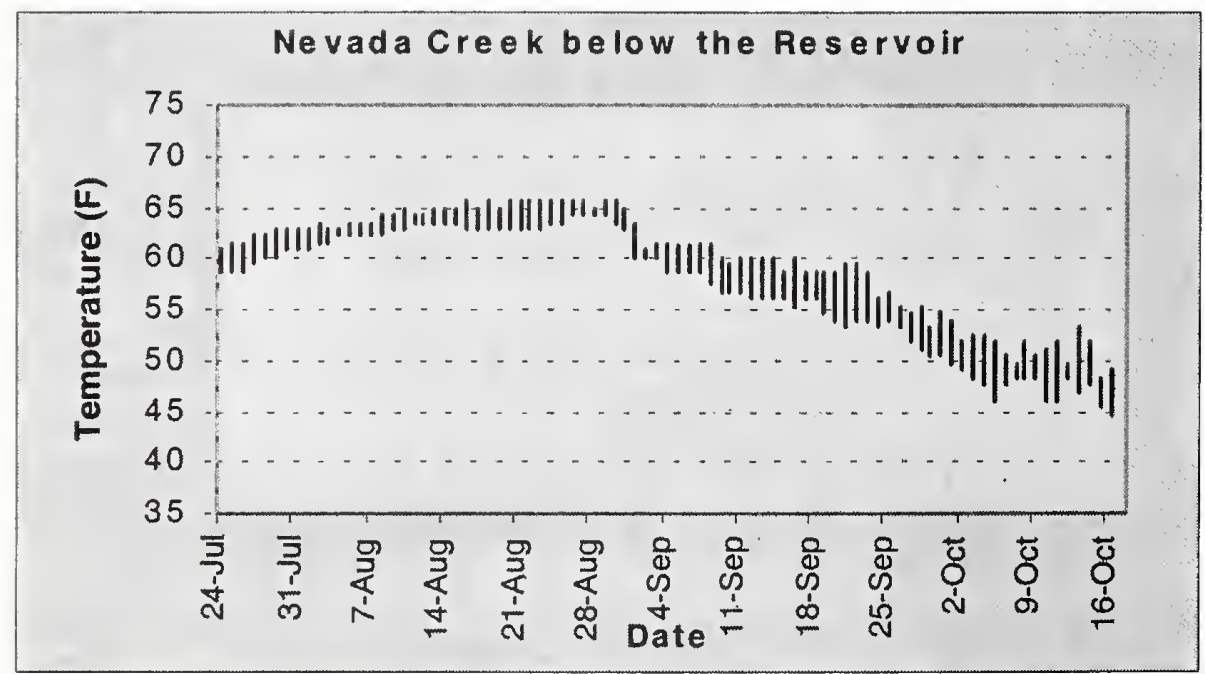

Month July August September October

$\begin{array}{lllll}\text { Monthly } & 60.7 & 63.6 & 56.9 & 48.8\end{array}$

Mean

Monthly

$62.8 \quad 65.6$

63.5

53.2

Max

Monthly

$58.7 \quad 60.8$

50.4

44.7

Min

Stdev

1.1

1.0

2.9

1.7 


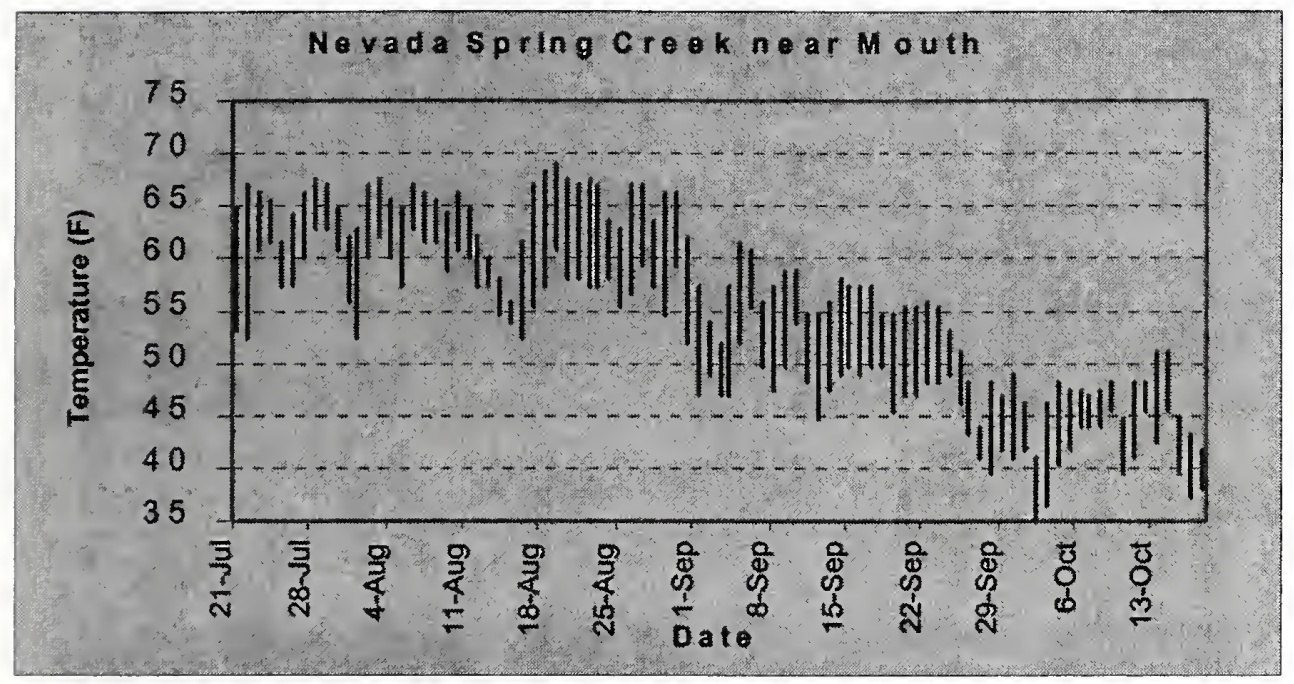

Month July August September October $\begin{array}{lllll}\text { Monthly } & 62.0 & 61.3 & 51.2 & 43.9\end{array}$

Mean

$\begin{array}{lllll}\text { Monthly } & 67.7 & 69.0 & 61.5 & 51.1\end{array}$

Max

Monthly

Min

Stdev

$3.7 \quad 3.8$

4.6

3.4 


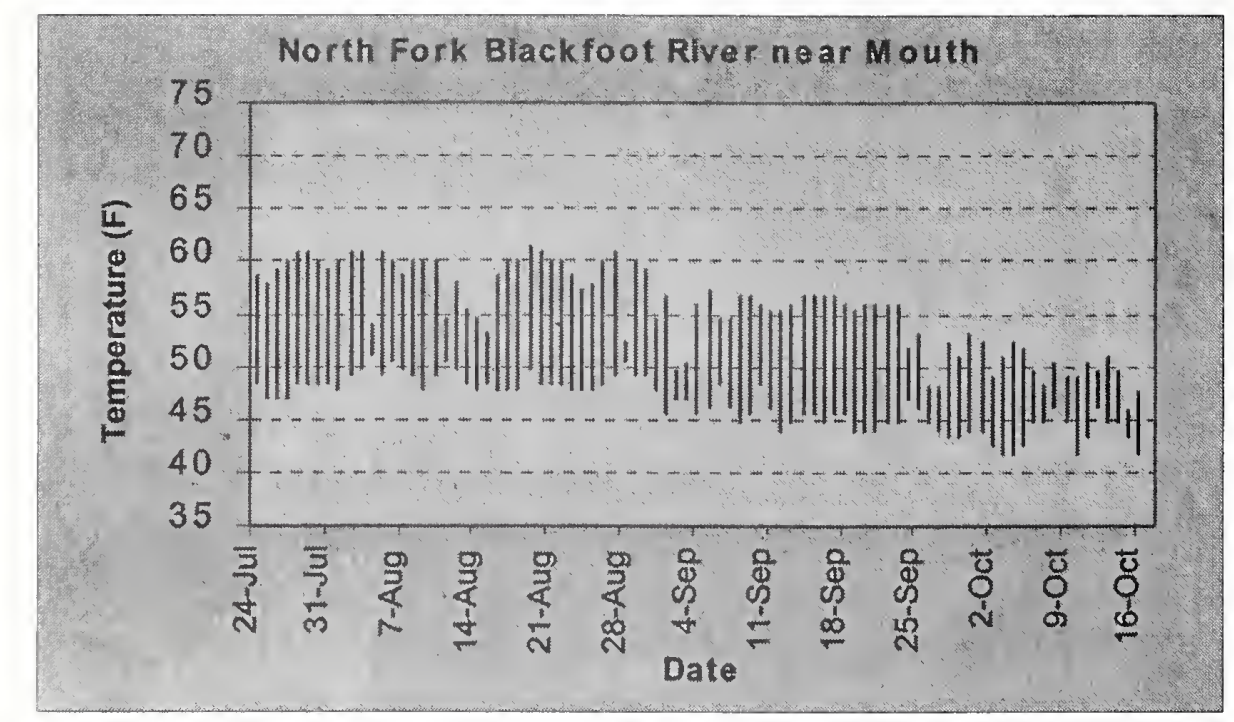

Month July August September October

$\begin{array}{lllll}\text { Monthly } & 53.1 & 52.9 & 49.0 & 46.2\end{array}$

Mean

$\begin{array}{lllll}\text { Monthly } & 60.1 & 61.5 & 57.4 & 52.5\end{array}$

Max

$\begin{array}{lllll}\text { Monthly } & 46.8 & 46.8 & 43.2 & 41.7\end{array}$

Min

$\begin{array}{lllll}\text { Stdev } & 4.2 & 3.7 & 3.6 & 2.5\end{array}$

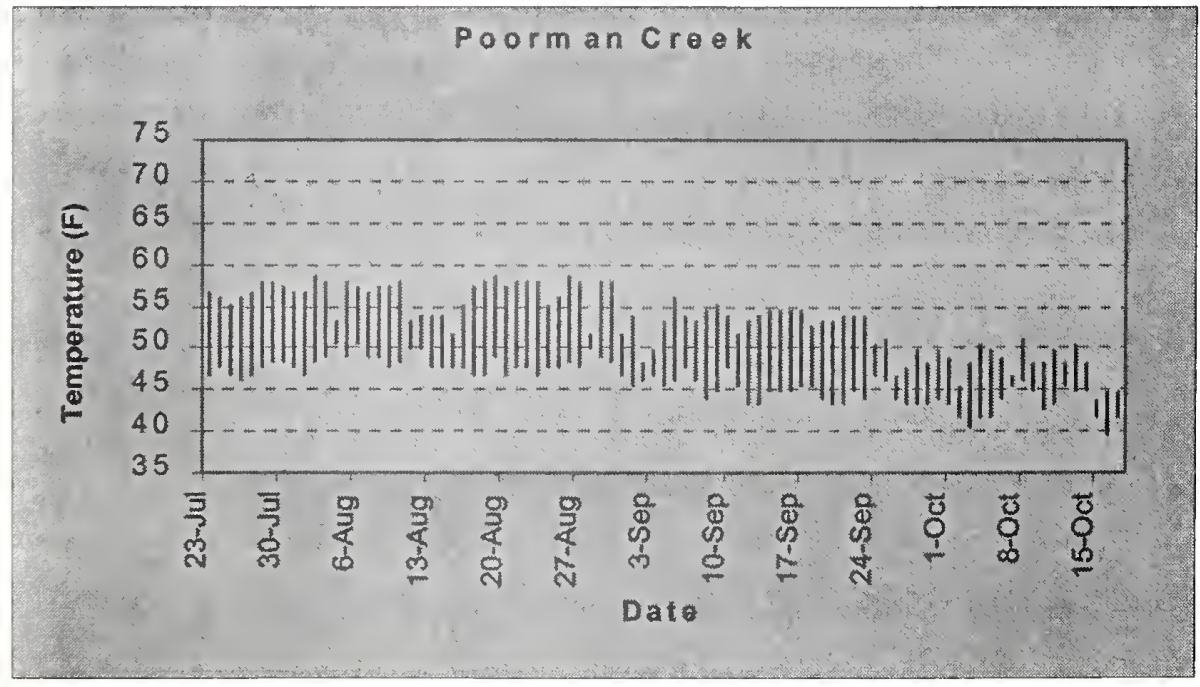

Month July August September October

$\begin{array}{lllll}\text { Monthly } & 51.2 & 51.5 & 47.9 & 45.2\end{array}$

Mean

Monthly

58.0

58.7

56.0

51.1

Max

Monthly

46.1

46.1

43.2

39.5

Min

Stdev

3.2

3.0

3.0

2.5 


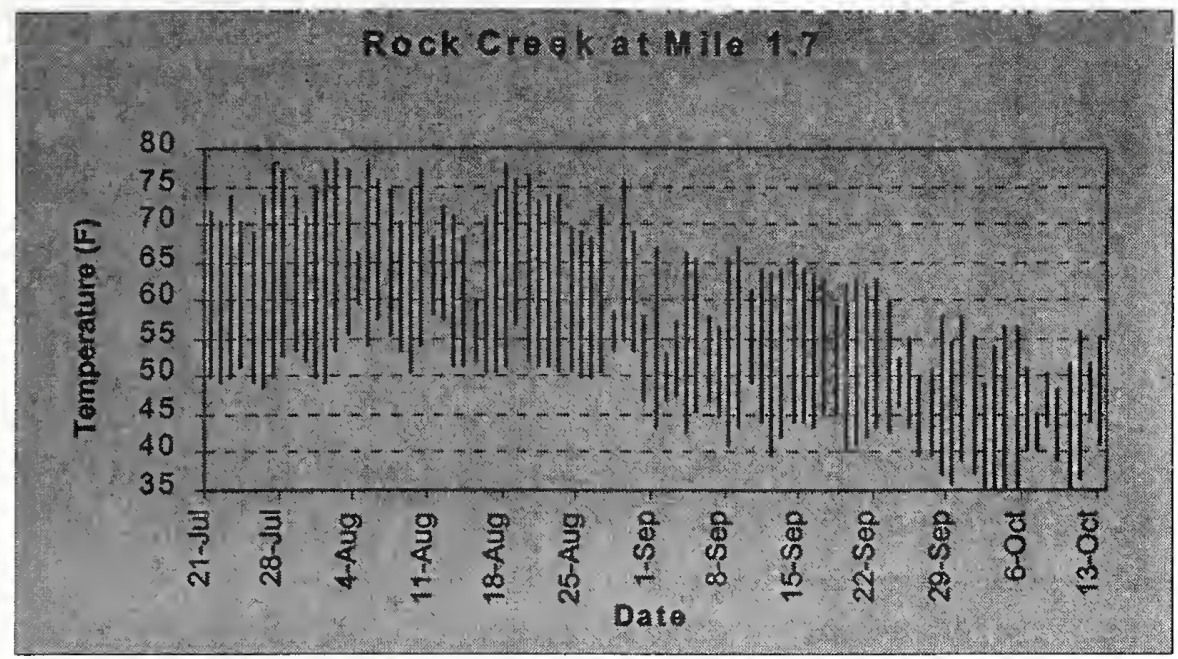

\begin{tabular}{lrrrr} 
Month & July & \multicolumn{4}{c}{ August } & \multicolumn{3}{c}{ September October } \\
Monthly & 60.3 & 60.8 & 50.5 & 44.1 \\
Mean & & & & \\
Monthly Max & 78.0 & 78.7 & 67.0 & 56.6 \\
Monthly Min & 48.3 & 45.4 & 35.7 & 34.1 \\
Stdev & 8.0 & 7.5 & 7.0 &
\end{tabular}

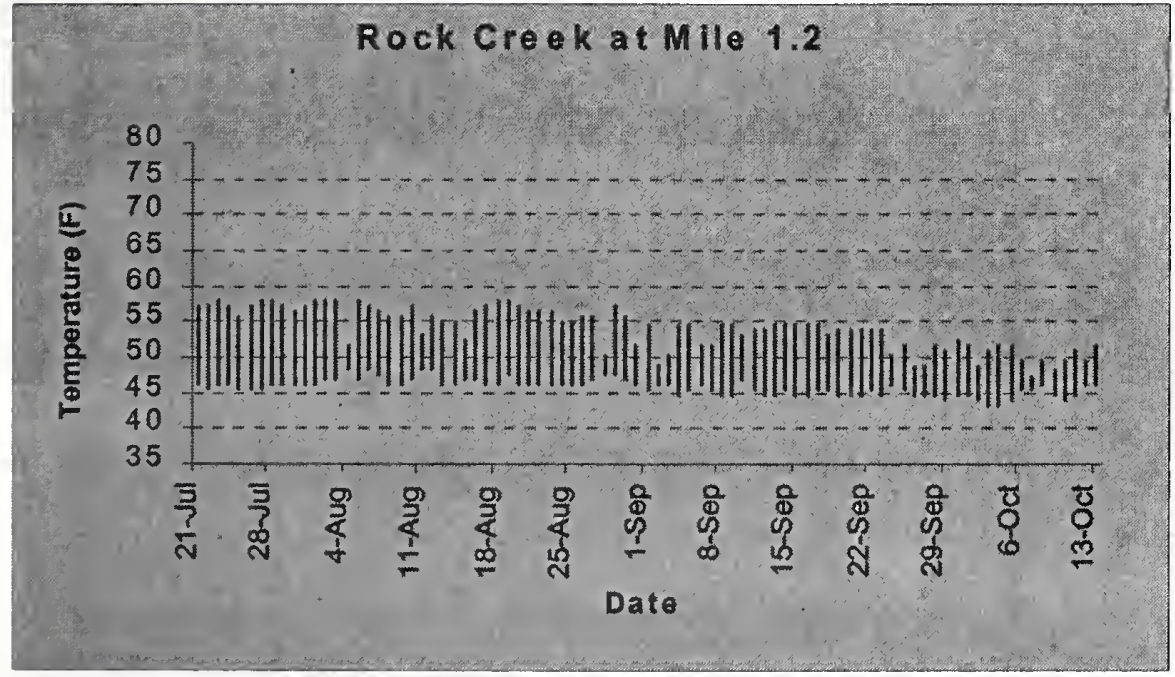

Month July August September October

$\begin{array}{lrrrr}\text { Monthly } & 50.6 & 50.4 & 48.1 & 46.8 \\ \begin{array}{l}\text { Mean } \\ \text { Monthly }\end{array} & 58.0 & 58.0 & 54.6 & 51.8 \\ \begin{array}{l}\text { Max } \\ \text { Monthly }\end{array} & 45.4 & 45.4 & 43.9 & 43.2 \\ \begin{array}{l}\text { Min } \\ \text { Stdev }\end{array} & 4.0 & 3.3 & 2.8 & 2.0\end{array}$



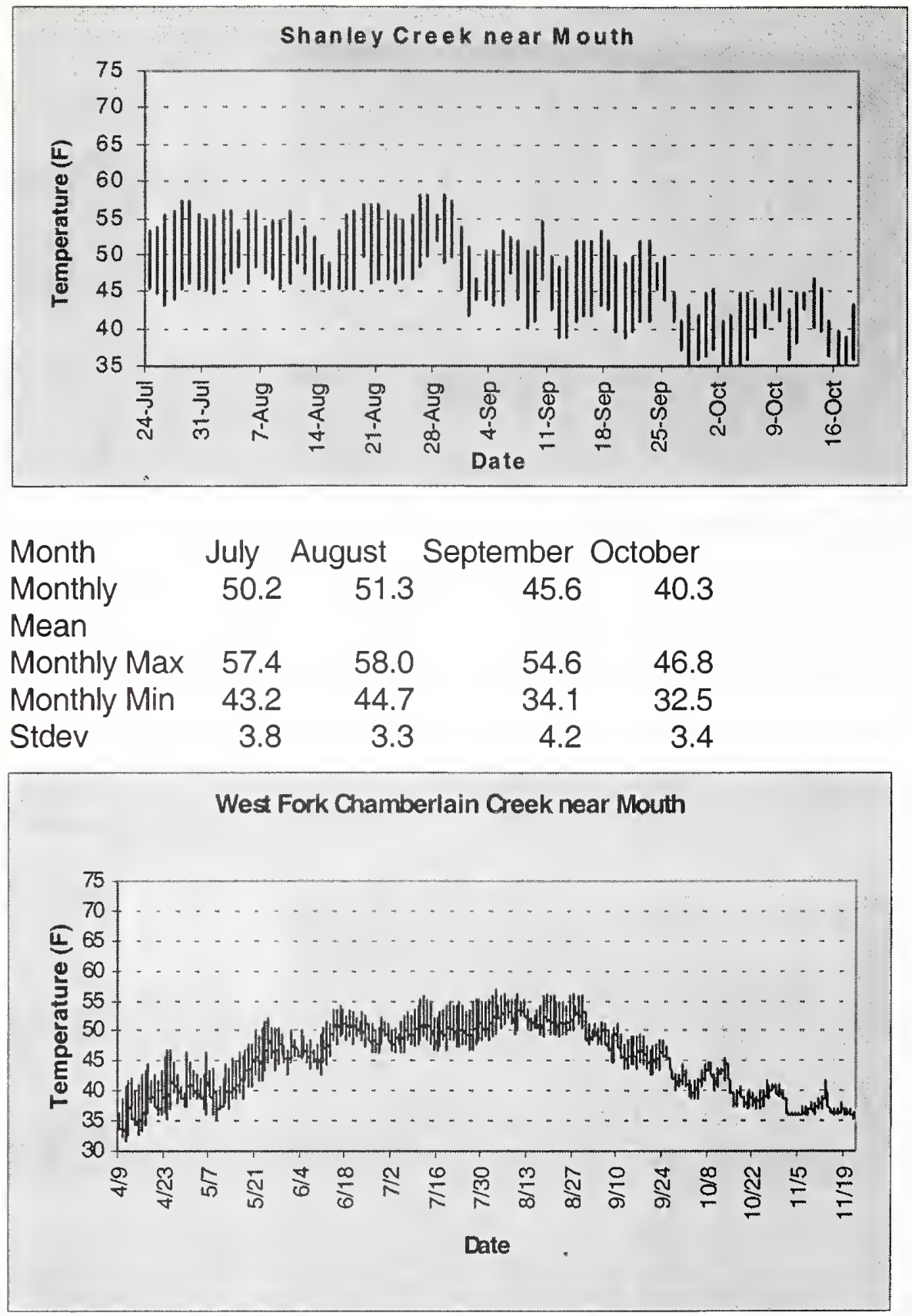

Month April May June July August September October November $\begin{array}{lllllllll}\text { Monthly } & 38.6 & 43.0 & 48.8 & 50.6 & 52.5 & 46.4 & 40.6 & 37.0\end{array}$ Mean

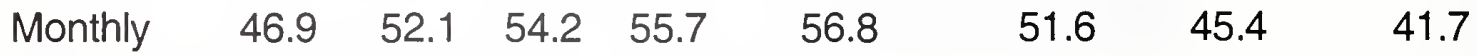
Max $\begin{array}{lllllllll}\text { Monthly } & 31.7 & 35.4 & 42.8 & 46.4 & 48.5 & 40.2 & 37.0 & 35.4\end{array}$ Min stdev $\begin{array}{llll}3.2 & 3.8 & 2.4 & 2.3\end{array}$ 


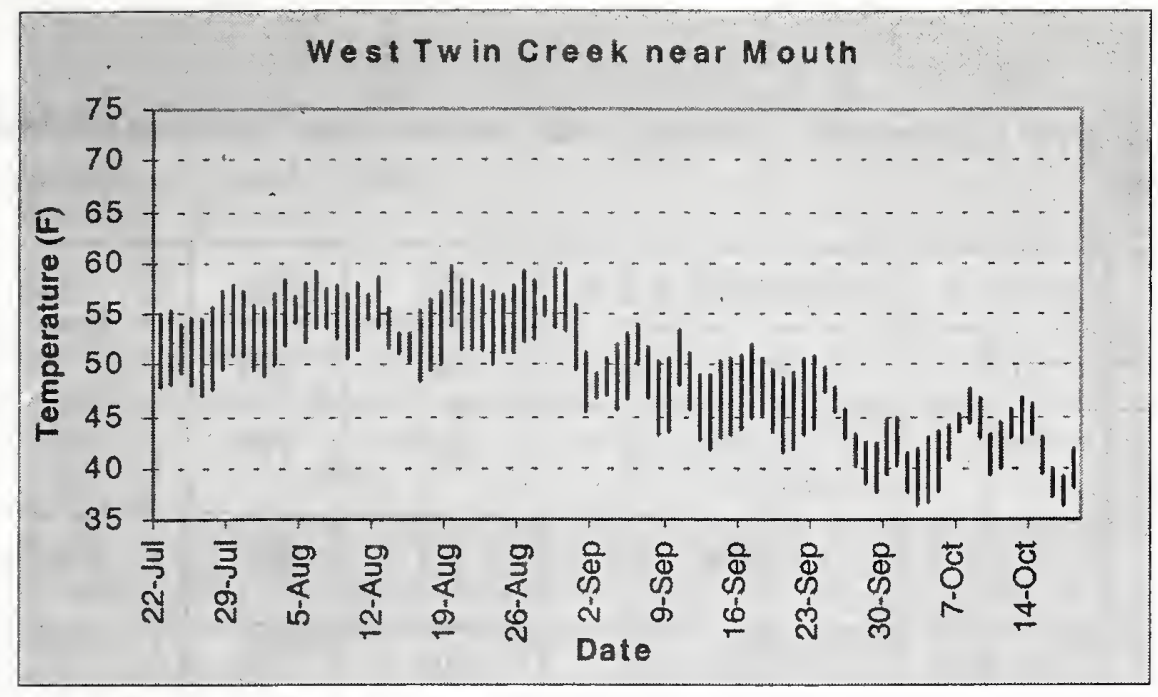

Month July August September October

$\begin{array}{lrrrr}\text { Monthly } & 52.1 & 54.5 & 46.7 & 41.9 \\ \begin{array}{l}\text { Mean } \\ \text { Monthly }\end{array} & 57.8 & 59.8 & 53.9 & 47.5 \\ \begin{array}{l}\text { Max } \\ \text { Monthly }\end{array} & 46.9 & 48.3 & 37.7 & 36.3 \\ \begin{array}{l}\text { Min } \\ \text { Stdev }\end{array} & 2.7 & 2.5 & 3.3 & 2.9\end{array}$

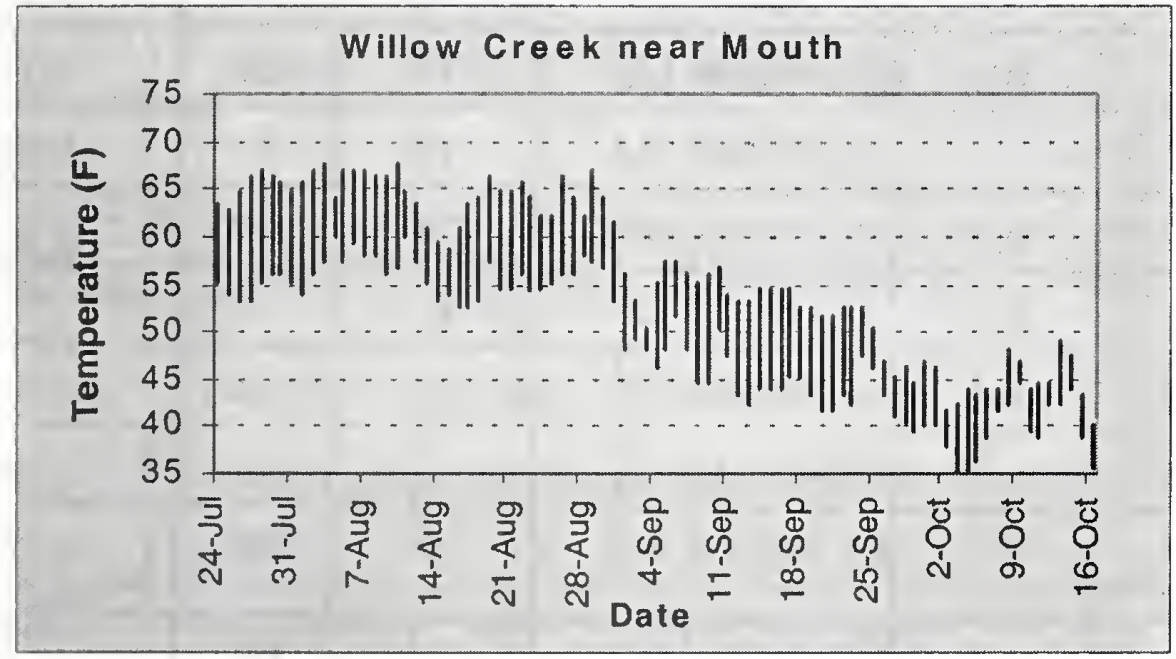

Month July August September October

$\begin{array}{lllll}\text { Monthly } & 60.1 & 60.1 & 48.7 & 42.0\end{array}$

Mean

$\begin{array}{lllll}\text { Monthly } & 67.0 & 67.7 & 57.4 & 49.0\end{array}$

Max

$\begin{array}{lllll}\text { Monthly } & 53.2 & 51.8 & 39.5 & 34.1\end{array}$

Min

Stdev

3.8

3.7

4.1

3.2 
Exhibit J. Westslope cutthroat trout genetic sampling results for the upper Blackfoot Watershed upstream of Nevada Creek.

\begin{tabular}{|c|c|c|c|c|c|l|}
\hline Poorman Creek & $8-10-99$ & $4.4 \& 7.4$ & $13 \mathrm{~N}, 8 \mathrm{~W}, 8 \mathrm{C} \& 22 \mathrm{~A}$ & 25 & 100 & \\
\hline Poorman Creek & $8-1-88$ & 9.4 & $13 \mathrm{~N}, 8 \mathrm{~W}, 24 \mathrm{~A}$ & 10 & 100 & \\
\hline $\begin{array}{c}\text { Poorman Creek } \\
\text { (South Fork) }\end{array}$ & $6-19-90$ & $\sim 0.8$ & $13 \mathrm{~N}, 7 \mathrm{~W}, 20 \mathrm{C}$ & 10 & 100 & \\
\hline $\begin{array}{c}\text { Poorman Creek } \\
\text { (South Fork) }\end{array}$ & $6-19-90$ & $\sim 1.5$ & $13 \mathrm{~N}, 7 \mathrm{~W}, 29 \mathrm{~A}$ & 10 & 100 & \\
\hline Sandbar Creek & $8-18-89$ & 2.0 & $15 \mathrm{~N}, 6 \mathrm{~W}, 32 \mathrm{D}$ & 20 & 100 & \\
\hline Sauerkraut Creek & $8-17-99$ & 0.2 & $14 \mathrm{~N}, 9 \mathrm{~W}, 29 \mathrm{C}$ & 11 & 100 & \\
\hline Sauerkraut Creek & $8-18-99$ & 3.0 & $13 \mathrm{~N}, 9 \mathrm{~W}, 5 \mathrm{D} \& 8 \mathrm{~A}$ & 13 & 100 & \\
\hline Sauerkraut Creek & $8-24-89$ & 5.8 & $13 \mathrm{~N}, 9 \mathrm{~W}, 18 \mathrm{D}$ & 10 & 100 & \\
\hline Sauerkraut Creek & $7-1-93$ & 5.8 & $13 \mathrm{~N}, 9 \mathrm{~W}, 18 \mathrm{D}$ & 10 & 100 & \\
\hline \begin{tabular}{c} 
SevenUp Pete Cr. \\
\hline
\end{tabular} & $8-9-99$ & $0.1 \& 0.5$ & $14 \mathrm{~N}, 8 \mathrm{~W}, 14 \mathrm{D} \&$ & 25 & 100 & \\
\hline SevenUp Pete Cr. & $4-1-90$ & 0.1 & $14 \mathrm{~N}, 8 \mathrm{~W}, 14 \mathrm{D}$ & 11 & 100 & \\
\hline SevenUp Pete Cr. & $8-1-90$ & 0.1 & $14 \mathrm{~N}, 8 \mathrm{~W}, 14 \mathrm{D}$ & 10 & 100 & \\
\hline Stonewall Creek & $8-1-88$ & $\sim 4.8$ & $15 \mathrm{~N}, 9 \mathrm{~W}, 34 \mathrm{~A}$ & 10 & 100 & \\
\hline Lower Willow Cr. & $8-3,4-99$ & 5.7 & $13 \mathrm{~N}, 9 \mathrm{~W}, 10 \mathrm{C}$ & 24 & 100 & \\
\hline Lower Willow Cr. & $8-90$ & 6.8 & $13 \mathrm{~N}, 9 \mathrm{~W}, 15 \mathrm{C}$ & 10 & 100 & \\
\hline $\begin{array}{c}\text { Lower Willow Cr. } \\
\text { (West Fork) }\end{array}$ & $8-3,4-99$ & 6.1 & $13 \mathrm{~N}, 9 \mathrm{~W}, 10 \mathrm{C}$ & 3 & 100 & \\
\hline $\begin{array}{c}\text { Lower Willow Cr. } \\
\text { (West Fork) }\end{array}$ & $8-24-89$ & 0.7 & $13 \mathrm{~N}, 9 \mathrm{~W}, 16 \mathrm{~A}$ & 10 & 100 & \\
\hline Upper Willow Cr. & $8-19-99$ & 0.7 & $15 \mathrm{~N}, 7 \mathrm{~W}, 35 \mathrm{D}$ & 4 & 100 & \\
\hline Upper Willow Cr. & $8-3-99$ & 1.1 & $14 \mathrm{~N}, 7 \mathrm{~W}, 2 \mathrm{~A} \& 1 \mathrm{~B}$ & 2 & 100 & \\
\hline Upper Willow Cr. & $8-2-99$ & 4.1 & $14 \mathrm{~N}, 6 \mathrm{~W}, 8 \mathrm{C}$ & 8 & 100 & \\
\hline
\end{tabular}


Exhibit $\mathbf{J}$. Westslope cutthroat trout genetic sampling results for the upper Blackfoot Watershed upstream of Nevada Creek.

\begin{tabular}{|c|c|c|c|c|c|c|}
\hline $\begin{array}{l}\text { Davis Gulch } \\
\text { (Trib to Poorman Cr.) }\end{array}$ & $8-88$ & $\sim 0 . .4$ & $13 \mathrm{~N}, 7 \mathrm{~W}, 17 \mathrm{~A}$ & 10 & 100 & \\
\hline Hogum Creek & $7-28-99$ & $0.4 \& 0.7$ & $14 \mathrm{~N}, 7 \mathrm{~W}, 8 \mathrm{~A} \& 8 \mathrm{D}$ & 25 & 99.3 & Rainbow \\
\hline Hogum Creek & $8-18-89$ & $\sim 3.1$ & $14 \mathrm{~N}, 7 \mathrm{~W}, 21 \mathrm{~B}$ & 15 & 100 & \\
\hline Humbug Creek & date & $\sim 2.0$ & $14 \mathrm{~N}, 7 \mathrm{~W}, 31 \mathrm{C}$ & 27 & 100 & \\
\hline $\begin{array}{c}\text { Humbug Creek } \\
\text { (South Fork) }\end{array}$ & date & $\sim 3.0$ & $13 \mathrm{~N}, 8 \mathrm{~W}, 1 \mathrm{~A}$ & 10 & 100 & \\
\hline $\begin{array}{c}\text { Humbug Creek } \\
\text { (South Fork) }\end{array}$ & $10-11-95$ & $\sim 3.8$ & $13 \mathrm{~N}, 7 \mathrm{~W}, 6 \mathrm{D}$ & 10 & 100 & \\
\hline Keep Cool Creek & $7-23-92$ & $\sim 9.0$ & $14 \mathrm{~N}, 8 \mathrm{~W}, 4 \mathrm{~B}$ & 10 & 100 & \\
\hline Landers Fork & $9-8-99$ & 0.1 & $14 \mathrm{~N}, 8 \mathrm{~W}, 13 \mathrm{~B}$ & 2 & 100 & \\
\hline Landers Fork & 9-8-99 & 4.6 & $\begin{array}{c}15 \mathrm{~N}, 8 \mathrm{~W}, 25 \mathrm{C} \& \\
36 \mathrm{~B}\end{array}$ & 1 & 100 & \\
\hline Landers Fork & 9-8-99 & 8.2 & $\begin{array}{c}15 \mathrm{~N}, 8 \mathrm{~W}, 13 \mathrm{~A} \& \\
12 \mathrm{C}\end{array}$ & 5 & 100 & \\
\hline Landers Fork & $10-23-91$ & 11.1 & $16 \mathrm{~N}, 8 \mathrm{~W}, 35 \mathrm{D}$ & 11 & 100 & \\
\hline $\begin{array}{c}\text { Landers Fork } \\
\text { (Byrnes Cr.) }\end{array}$ & $7-1-91$ & 0.2 & $16 \mathrm{~N}, 8 \mathrm{~W}, 26 \mathrm{~A}$ & 10 & 100 & \\
\hline $\begin{array}{l}\text { Landers Fork } \\
\text { (Middle Fork) }\end{array}$ & date & $\underbrace{@}_{25.1}$ mouth & $17 \mathrm{~N}, 9 \mathrm{~W}, 26 \mathrm{~A}$ & 10 & 100 & \\
\hline Little Moose Cr. & $8-6-90$ & $\sim 0.1$ & $14 \mathrm{~N}, 10 \mathrm{~W}, 26 \mathrm{D}$ & 6 & 100 & \\
\hline Little Moose Cr. & $8-90$ & $\sim 0.7$ & $14 \mathrm{~N}, 10 \mathrm{~W}, 35 \mathrm{~A}$ & 10 & 100 & \\
\hline Liverpool Creek & $8-88$ & $\sim 3.8$ & $15 \mathrm{~N}, 8 \mathrm{~W}, 31 \mathrm{C}$ & 10 & 100 & \\
\hline $\begin{array}{l}\text { Moose Creek } \\
\text { (below culvert) }\end{array}$ & $8-26-99$ & 0.3 & $\begin{array}{c}14 \mathrm{~N}, 10 \mathrm{~W}, 33 \mathrm{D} \& \\
34 \mathrm{C}\end{array}$ & 14 & 100 & \\
\hline $\begin{array}{c}\text { Moose Creek } \\
\text { (above culvert) }\end{array}$ & $8-26-99$ & 0.5 & $14 \mathrm{~N}, 10 \mathrm{~W}, 34 \mathrm{C}$ & 11 & 99.2 & Rainbow \\
\hline Moose Creek & 8-24-89 & 0.5 & $14 \mathrm{~N}, 10 \mathrm{~W}, 34 \mathrm{C}$ & 7 & 100 & \\
\hline Park Creek & $8-88$ & 2.0 & $15 \mathrm{~N}, 9 \mathrm{~W}, 36 \mathrm{C}$ & 10 & 100 & \\
\hline Pass Creek & $7-31-89$ & $\sim 0.1$ & $15 \mathrm{~N}, 6 \mathrm{~W}, 20 \mathrm{~A}$ & 11 & 100 & \\
\hline
\end{tabular}


Exhibit J. Westslope cutthroat trout genetic sampling results for the upper Blackfoot Watershed upstream of Nevada Creek.

\begin{tabular}{|c|c|c|c|c|c|c|}
\hline Stream Name & Date & $\begin{array}{c}\text { Location } \\
\text { (stream } \\
\text { mile) }\end{array}$ & $\begin{array}{c}\text { Township,Range, } \\
\text { Section }\end{array}$ & $\begin{array}{c}\text { \# of } \\
\text { Samples } \\
\text { analyzed }\end{array}$ & $\begin{array}{c}\% \\
\text { Purity }\end{array}$ & Introgression \\
\hline Alice Creek & $7-27-99$ & 3.1 & $15 \mathrm{~N}, 7 \mathrm{~W}, 21 \mathrm{~A}$ & 2 & 100 & \\
\hline $\begin{array}{l}\text { Alice Creek } \\
\text { (Toms Gulch) }\end{array}$ & $4-1-91$ & 3.0 & $16 \mathrm{~N}, 7 \mathrm{~W}, 32 \mathrm{~A}$ & 10 & 100 & \\
\hline Alice Creek & $8-1-88$ & 12.5 & $16 \mathrm{~N}, 7 \mathrm{~W}, 23 \mathrm{~B}$ & 11 & 100 & \\
\hline Anaconda Creek & $7-1-93$ & 0.3 & $15 \mathrm{~N}, 6 \mathrm{~W}, 27 \mathrm{~B}$ & 10 & 100 & \\
\hline Arrastra Creek & $9-15-99$ & 0.3 & $14 \mathrm{~N}, 10 \mathrm{~W}, 30 \mathrm{~A}$ & 3 & 100 & \\
\hline Arrastra Creek & $9-15-99$ & 0.7 & $14 \mathrm{~N}, 10 \mathrm{~W}, 29 \mathrm{~B}$ & 12 & 100 & \\
\hline Arrastra Creek & $9-15-99$ & 9.2 & $15 \mathrm{~N}, 10 \mathrm{~W}, 24 \mathrm{C}$ & 16 & 100 & \\
\hline Arrastra Creek & $8-88$ & 9.2 & $15 \mathrm{~N}, 10 \mathrm{~W}, 24 \mathrm{C}$ & 9 & 100 & \\
\hline Bartlett Creek & $7-26-99$ & 0.4 & $15 \mathrm{~N}, 7 \mathrm{~W}, 22 \mathrm{D}$ & 14 & 98.8 & Rainbow \\
\hline Beartrap Creek & $8-88$ & 1.0 & $15 \mathrm{~N}, 6 \mathrm{~W}, 27 \mathrm{D}$ & 12 & 100 & \\
\hline Beaver Creek & $9-1-99$ & 5.4 & $15 \mathrm{~N}, 9 \mathrm{~W}, 32 \mathrm{~A}$ & 25 & 100 & \\
\hline Beaver Creek & $8-88$ & 4.4 & $15 \mathrm{~N}, 9 \mathrm{~W}, 33 \mathrm{C}$ & 10 & 100 & \\
\hline $\begin{array}{c}\text { Black Diamond } \\
\text { Creek }\end{array}$ & 8-18-89 & $\sim 2.1$ & $14 \mathrm{~N}, 7 \mathrm{~W}, 15 \mathrm{D}$ & 10 & 100 & \\
\hline Blackfoot River & $7-27-92$ & $\sim 130$ & $15 \mathrm{~N}, 6 \mathrm{~W}, 20 \mathrm{~B}$ & 10 & 100 & \\
\hline $\begin{array}{l}\text { Blackfoot River } \\
\text { (Upstr. Hogum Cr. Rd.) }\end{array}$ & $8-25,31-99$ & 120 & $14 \mathrm{~N}, 7 \mathrm{~W}, 5 \mathrm{D} \& 14 \mathrm{C}$ & 8 & 100 & \\
\hline $\begin{array}{l}\text { Blackfoot River } \\
\text { (Upstr. Flesher Pass Rd.) }\end{array}$ & $8-24,30-99$ & 124.3 & $15 \mathrm{~N}, 7 \mathrm{~W}, 35 \mathrm{~B}$ & 15 & 99.8 & Rainbow \\
\hline Copper Creek & 9-9-99 & 1.1 & $15 \mathrm{~N}, 8 \mathrm{~W}, 25 \mathrm{C}$ & 6 & 100 & \\
\hline Copper Creek & $8-88$ & $\sim 3.5$ & $15 \mathrm{~N}, 8 \mathrm{~W}, 22 \mathrm{~A}$ & 11 & 100 & \\
\hline Copper Creek & $7-1-89$ & $\sim 5.5$ & $15 \mathrm{~N}, 8 \mathrm{~W}, 10 \mathrm{C}$ & 26 & 100 & \\
\hline Copper Creek & 9-9-99 & 6.2 & $15 \mathrm{~N}, 8 \mathrm{~W}, 9 \mathrm{~A}$ & 11 & 100 & \\
\hline Copper Creek & 9-9-99 & 8.9 & $15 \mathrm{~N}, 8 \mathrm{~W}, 5 \mathrm{~B}$ & 4 & 100 & \\
\hline Copper Creek & $9-9-99$ & 10.8 & $15 \mathrm{~N}, 9 \mathrm{~W}, 1 \mathrm{~A}$ & 4 & 100 & \\
\hline
\end{tabular}


Montana

January 10,2000

Division of Biological Sciences

The University of Montana

Missoula, Montana 59812-4824

Phone: (406) 243-5122

FAX: (406) 243-4184

Ron Pierce

Montana Department of Fish, Wildlife, and Parks

3201 Spurgin Rd.

Missoula, MT 59804

Ron:

We have completed the electrophoretic analysis of the trout collected from 28 locations in the Blackfoot River drainage during summer of 1999 (Table 1). The Paired Interspersed Nuclear DNA Element-PCR (PINE-PCR) method was used to determine each fish's genetic characteristics at 21 regions of nuclear DNA. This method produces DNA fragments (hereafter PINE markers) that distinguish westslope cutthroat trout, Oncorhynchus clarki lewisi, from rainbow trout, O. mykiss (Table 1). This situation also pertains to a comparison of westslope and Yellowstone cutthroat trout, O. c. bouvieri (Table 2). These species specific PINE markers, therefore, can be used to determine whether a sample came from a genetically pure population of one of these fishes or one in which hybridization between two or all three of them has or is occurring.

Presence of a PINE marker is dominant to absence. The presence of the marker indicates the individual is either heterozygous or homozygous for the marker. The frequency of each marker in each sample is thus estimated as one minus the square root of the frequency of fish lacking the marker. This procedure assumes the genetic characteristics of the population conform to random mating expectations which is tested using three microsatellite loci. The degree of hybridization in the population is then estimated as the average frequency of the markers that are specific to the introduced species.

PINE markers characteristic of only westslope cutthroat trout were detected in the following samples:

$\begin{array}{llllr}\text { Location } & \text { T } & \text { R } & \text { S } & \text { N } \\ \text { Alice Cr. } & 15 \mathrm{~N} & 7 \mathrm{~W} & 21 & 2 \\ \text { Upper Willow Cr. } & 14 \mathrm{~N} & 6 \mathrm{~W} & 8 & 8 \\ \text { Upper Willow Cr. } & 14 \mathrm{~N} & 7 \mathrm{~W} & 1 \& 2 & 2 \\ \text { Upper Willow Cr. } & 14 \mathrm{~N} & 7 \mathrm{~W} & 35 & 4 \\ \text { Lower Willow Cr. } & 13 \mathrm{~N} & 7 \mathrm{~W} & 10 & 24 \\ \text { West Willow Cr. } & 13 \mathrm{~N} & 9 \mathrm{~W} & 10 & 3 \\ \text { Sevenup Pete } & 14 \mathrm{~N} & 8 \mathrm{~W} & 14 \& 24 & 25 \\ \text { Poorman Cr. } & 13 \mathrm{~N} & 8 \mathrm{~W} & 8 \& 22 & 25\end{array}$
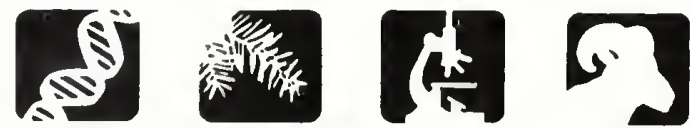


$\begin{array}{llllr}\text { Lower Sauerkraut Cr. } & 14 \mathrm{~N} & 9 \mathrm{~W} & 29 & 12 \\ \text { Sauerkraut Cr. } & 13 \mathrm{~N} & 9 \mathrm{~W} & 5 \& 8 & 13 \\ \text { Blackfoot R. at Hogum Cr. } & 14 \mathrm{~N} & 7 \mathrm{~W} & 5 \& 4 & 8 \\ \text { Moose Cr. below culvert } & 14 \mathrm{~N} & 10 \mathrm{~W} & 33 \& 34 & 14 \\ \text { Beaver Cr. } & 15 \mathrm{~N} & 9 \mathrm{~W} & 32 & 25 \\ \text { Landers Fork at mouth } & 14 \mathrm{~N} & 8 \mathrm{~W} & 13 & 2 \\ \text { Landers Fork below falls } & 15 \mathrm{~N} & 8 \mathrm{~W} & 13 & 5 \\ \text { Landers Fork at Copper Cr. } & 15 \mathrm{~N} & 8 \mathrm{~W} & 36 \& 25 & 1 \\ \text { Copper Cr. at road crossing } & 15 \mathrm{~N} & 8 \mathrm{~W} & 5 & 4 \\ \text { Copper Cr. at Snowbank L. Bridge } & 15 \mathrm{~N} & 8 \mathrm{~W} & 9 & 11 \\ \text { Copper Cr. at Sucker Cr. Bridge } & 15 \mathrm{~N} & 8 \mathrm{~W} & 25 & 6 \\ \text { Copper Cr. at Red Creek Bridge } & 15 \mathrm{~N} & 9 \mathrm{~W} & 1 & 4 \\ \text { Arrastra Cr. below culvert } & 15 \mathrm{~N} & 10 \mathrm{~W} & 24 & 16 \\ \text { Arrastra Cr. upstream Hwy200 } & 14 \mathrm{~N} & 10 \mathrm{~W} & 29 & 12 \\ \text { Arrastra Cr. below Hwy200 } & 14 \mathrm{~N} & 10 \mathrm{~W} & 30 & 3 \\ & & & & \end{array}$

We are able to have a $95 \%$ chance of detecting as little as a 1\% rainbow trout and Yellowstone cutthroat trout genetic contribution to a population when a sample size reaches 25 (Table 3). We, therefore, cannot reasonably exclude the possibility that some of the populations, whose sample sizes are smaller than 25 , may be slightly hybridized with rainbow trout, Yellowstone cutthroat trout, or both. Unless demonstrated otherwise, the conservative approach would be to manage them as pure westslope cutthroat trout.

PINE markers characteristic of both westslope cutthroat trout and rainbow trout were detected in the samples from McCabe Creek, Bartlett Creek, Hogum Creek, Blackfoot River upstream of Flasher Pass Rd., and Moose Creek above culvert (Table 4). These samples, therefore, came from hybridized populations of westslope cutthroat trout and rainbow trout.

Sincerely,

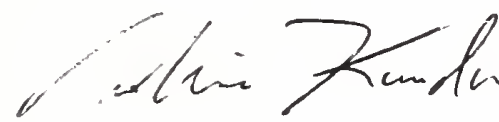

Naohisa Kanda 
Table 1. Location, township (T), range (R), section (S), collected date, and number $(N)$ of trout samples.

\begin{tabular}{lllllrl}
\hline Location & T & R & S & Collected & N & Note \\
\hline McCabe Cr. & $15 \mathrm{~N}$ & $12 \mathrm{~W}$ & $4 \& 5$ & $7 / 20,8 / 23 / 99$ & $25(24)^{\mathrm{a}}$ & \\
Bartlett Cr. & $15 \mathrm{~N}$ & $7 \mathrm{~W}$ & 22 & $7 / 26 / 99$ & 14 & \\
Alice Cr. & $15 \mathrm{~N}$ & $7 \mathrm{~W}$ & 21 & $7 / 27 / 99$ & 2 & \\
Hogum Cr. & $14 \mathrm{~N}$ & $7 \mathrm{~W}$ & 8 & $7 / 28 / 99$ & 25 & \\
Upper Willow Cr. & $14 \mathrm{~N}$ & $6 \mathrm{~W}$ & 8 & $8 / 2 / 99$ & 8 & \\
Upper Willow Cr. & $14 \mathrm{~N}$ & $7 \mathrm{~W}$ & $1 \& 2$ & $8 / 3 / 99$ & 2 & \\
Upper Willow Cr. & $14 \mathrm{~N}$ & $7 \mathrm{~W}$ & 35 & $8 / 19 / 99$ & 4 & \\
Lower Willow Cr. & $13 \mathrm{~N}$ & $7 \mathrm{~W}$ & 10 & $8 / 3,4 / 99$ & 24 & \\
West Willow Cr. & $13 \mathrm{~N}$ & $9 \mathrm{~W}$ & 10 & $8 / 3,4 / 99$ & 3 & \\
Sevenup Pete & $14 \mathrm{~N}$ & $8 \mathrm{~W}$ & $14 \& 248 / 9 / 99$ & 25 & \\
Poorman Cr. & $13 \mathrm{~N}$ & $8 \mathrm{~W}$ & $8 \& 22$ & $8 / 10 / 99$ & 25 & \\
Lower Sauerkraut Cr. $14 \mathrm{~N}$ & $9 \mathrm{~W}$ & 29 & $8 / 17 / 99$ & $12(11)^{b}$ & \\
Sauerkraut Cr. & $13 \mathrm{~N}$ & $9 \mathrm{~W}$ & $5 \& 8$ & $8 / 18 / 99$ & 13 & \\
Blackfoot R. & $15 \mathrm{~N}$ & $7 \mathrm{~W}$ & 35 & $8 / 24,30 / 99$ & $19(15)^{\mathrm{b}}$ & upstream Flasher Pass Rd. \\
Blackfoot R. & $14 \mathrm{~N}$ & $7 \mathrm{~W}$ & $5 \& 4$ & $8 / 25,31 / 99$ & 8 & upstream Hogum Cr. \\
Moose Cr. & $14 \mathrm{~N}$ & $10 \mathrm{~W}$ & $33 \& 348 / 26 / 99$ & 14 & below culvert \\
Moose Cr. & $14 \mathrm{~N}$ & $10 \mathrm{~W}$ & 34 & $8 / 26 / 99$ & 11 & above culvert \\
Beaver Cr. & $15 \mathrm{~N}$ & $9 \mathrm{~W}$ & 32 & $9 / 1 / 99$ & 25 & \\
Landers Fork & $14 \mathrm{~N}$ & $8 \mathrm{~W}$ & 13 & $9 / 8 / 99$ & 2 & upstream from mouth \\
Landers Fork & $15 \mathrm{~N}$ & $8 \mathrm{~W}$ & 13 & $9 / 8 / 99$ & 5 & below falls at headwater \\
Landers Fork & $15 \mathrm{~N}$ & $8 \mathrm{~W}$ & $36 \& 259 / 8 / 99$ & 1 & upstream from Copper Cr. \\
Copper Cr. & $15 \mathrm{~N}$ & $8 \mathrm{~W}$ & 5 & $9 / 9 / 99$ & 4 & at road crossing \\
Copper Cr. & $15 \mathrm{~N}$ & $8 \mathrm{~W}$ & 9 & $9 / 9 / 99$ & 11 & at Snowbank L. Bridge \\
Copper Cr. & $15 \mathrm{~N}$ & $8 \mathrm{~W}$ & 25 & $9 / 9 / 99$ & 6 & at Sucker Cr. Bridge \\
Copper Cr. & $15 \mathrm{~N}$ & $9 \mathrm{~W}$ & 1 & $9 / 9 / 99$ & 4 & at Red Cr. Bridge \\
Arrastra Cr. & $15 \mathrm{~N}$ & $10 \mathrm{~W}$ & 24 & $9 / 15 / 99$ & 16 & below culvert \\
Arrastra Cr. & $14 \mathrm{~N}$ & $10 \mathrm{~W}$ & 29 & $9 / 15 / 99$ & 12 & upstream from Hwy200 \\
Arrastra Cr. & $14 \mathrm{~N}$ & $10 \mathrm{~W}$ & 30 & $9 / 15 / 99$ & 3 & below Hwy200 \\
\hline & & & & & &
\end{tabular}

a: One of the 25 vials did not contain fin clip.

b: actual number of fish whose DNA were successfully extracted and analyzed. 
Table 2. PINE markers that distinguish between westslope cutthroat trout and Yellowstone cutthroat trout and between westslope cutthroat trout and rainbow trout.

Species $\quad$ PINE markers

$\begin{array}{ll}\text { Westslope } & 110,153,162,242 \\ \text { Yellowstone } & 138,159,170,173,232,248 \\ \text { Westslope } & 69,72,110,148,153,162,242,366,388 \\ \text { Rainbow } & 66,70,230,266,395,369\end{array}$

Note: Presence of a PINE marker is dominant to absence. The appearance of a marker indicates the individual is either heterozygous or homozygous for the marker. The frequency of each marker in each sample, therefore, is estimated as one minus the square root of the frequency of fish lacking the marker. This procedure assumes the genetic characteristics of the population conform to random mating expectations which is tested using three microsatellite loci. The degree of hybridization in a population is then estimated as the average frequency of the markers that are specific to the introduced species. 
Table 3. Minimum percent of hybridization of westslope cutthroat trout with rainbow trout or Yellowstone cutthroat trout that we can detect with $95 \%$ certainty for particular sample sizes $(N)$.

\begin{tabular}{rlllll}
\hline $\mathrm{N}$ & Percent & $\mathrm{N}$ & Percent & $\mathrm{N}$ & Percent \\
\hline 1 & 22.1 & 11 & 2.3 & 21 & 1.2 \\
2 & 11.7 & 12 & 2.1 & 22 & 1.2 \\
3 & 8.0 & 13 & 1.9 & 23 & 1.1 \\
4 & 6.1 & 14 & 1.8 & 24 & 1.1 \\
5 & 4.9 & 15 & 1.7 & 25 & 1.0 \\
6 & 4.1 & 16 & 1.6 & 30 & 0.9 \\
7 & 3.5 & 17 & 1.5 & 35 & 0.8 \\
8 & 3.1 & 18 & 1.4 & 40 & 0.7 \\
9 & 2.8 & 19 & 1.3 & 45 & 0.6 \\
10 & 2.5 & 20 & 1.3 & 50 & 0.5 \\
\hline
\end{tabular}


Table 4. Frequencies of PINE markers distinguishing westslope cutthroat trout from rainbow trout in the samples from hybridized populations of these fishes in McCabe Creek, Bartlett Creek, Hogum Creek, Blackfoot River upstream of Flasher Pass Rd., and Moose Creek above culvert.

PINE marker

Samples and frequencies

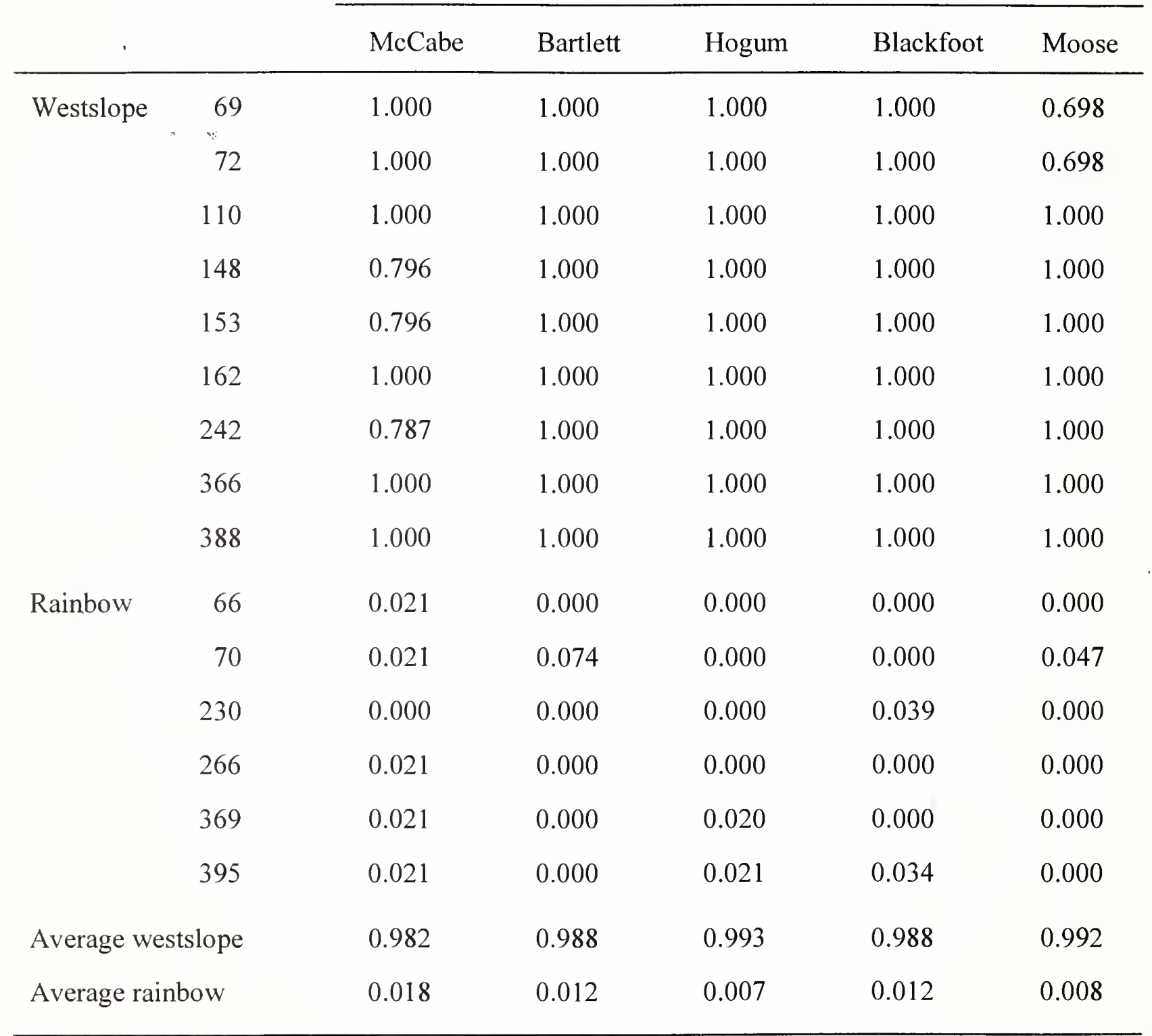

Note: To avoid overestimating the average westslope cutthroat trout genetic contribution due to the dominance of PINE markers, averages are estimated using only the markers unique to rainbow trout. It is the presence of these markers that definitely indicate the presence of rainbow trout hybridization. Average frequency of westslope cutthroat trout, therefore, is one minus the average frequency of rainbow trout markers. 

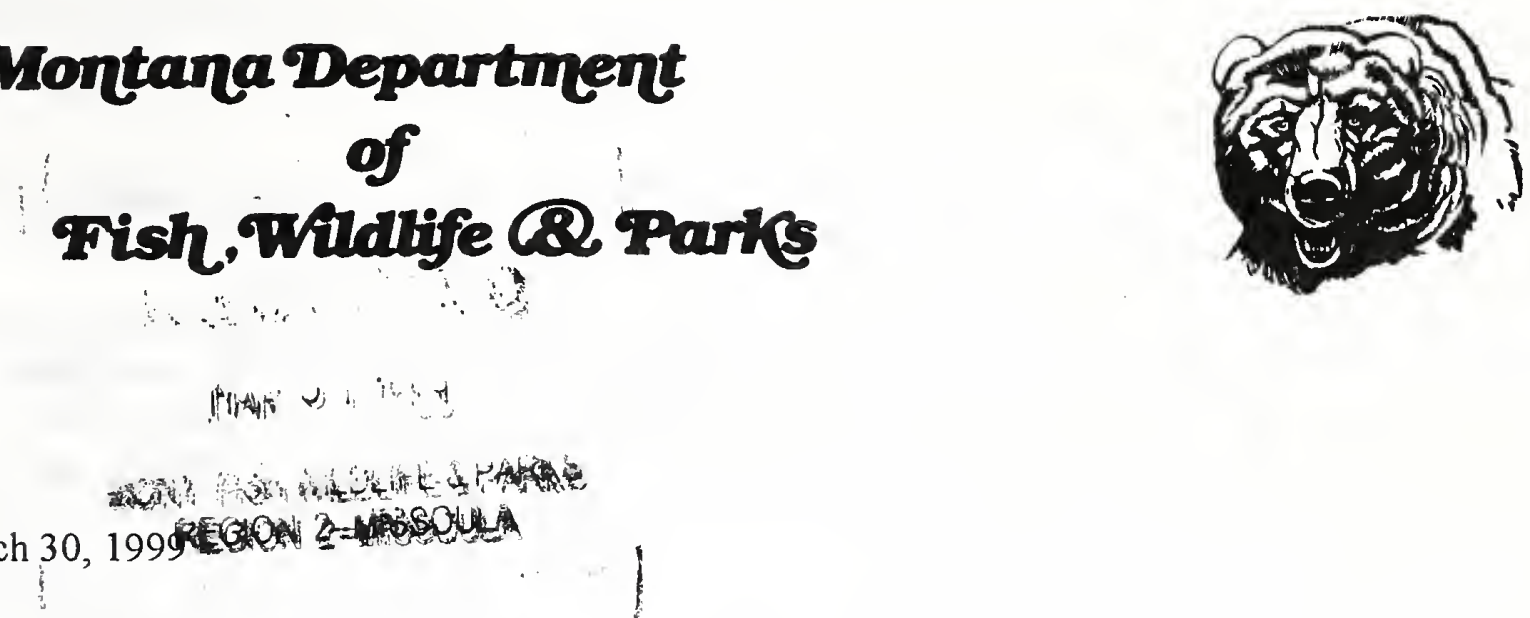

March 30, 1999)

To: Ron Pierce

Fm: Dick Vincent Sucic

Subj: Big Blackfoot River Live Cage Results

Enclosed is most of the 1997 whirling disease live cage data from the Big Blackfoot River and selected tributaries. There were six sites on the mainstem river and six sites on the selected tributaries. The original 12 sites were exposed for a ten day period from July 1 through July $11^{\text {th }}$. Of the original 12 sites, two were repeated because of very high mean daily water temperatures during the exposure period (Lower Big Blackfoot - Bonner and Warren Cr Sept 28 - Oct 8, 1998). These two exposures have yet to be returned from Washington State University. As you recall from my talk at the Whirling Disease Symposium in February, infection rates are highly dependent on mean daily water temperatures with the optimum temperatures of infection being between $50 \mathrm{~F}$ and $60 \mathrm{~F}$, see enclosed graph from Willow Creek exposures.

The following table shows the results for the July 1998 live cage tests for whirling disease in the Big Blackfoot River Drainage. As you can see by the Mean Grade of Infection most of the sites have rates below what I feel is dangerous to the wild trout populations with the exceptions being Lower Kleinschmidt Creek and Cottonwood Creek which are defiantly high enough to cause population or reproduction damage. The site in the mainstem above the Clearwater River is also troubling in that the 1.10 mean grade infection is very high considering the high mean daily water temperature of $63.0 \mathrm{~F}$. This infection at the optimum water temperatures could well be in the low three's. This site bears watching. The Bonner site on the lower Big Blackfoot is too warm during the exposure period to produce any meaningful data, as was Warren Creek, thus we reexposed fish there in late September - early October. I feel it would be highly beneficial to run another live cage series in 1999 to: 1) have another data set at cooler water temperatures; 2) determine if infection rates at each site are stable or increasing; and 3) add a few new tributary sites to further expand the WD database. 
Table 1. Whirling Disease test results for 12 sites in Big Blackfoot River Drainage for the July 1 11, 1999 period.

\begin{tabular}{|l|l|l|l|l|}
\hline Site & No fish & $\begin{array}{l}\text { Percent } \\
\text { Infected }\end{array}$ & $\begin{array}{l}\text { Mean } \\
\text { Grade } \\
\text { Infection }\end{array}$ & $\begin{array}{l}\text { Mean daily } \\
\text { temp using } \\
\text { high 4 days }\end{array}$ \\
\hline BBR-1 Lower Big Blackfoot & 36 & I4\% & 0.22 & $64.7 \mathrm{~F}$ \\
\hline BBR-2 Big Blackfoot below Elk Cr & 41 & $15 \%$ & 0.21 & No Data \\
\hline $\begin{array}{l}\text { BBR-3 Big Blackfoot above } \\
\text { Clearwater River }\end{array}$ & 20 & $52 \%$ & 1.10 & 63.0 \\
\hline BBR-4 Big Blackfoot Below N. Fork & 41 & $15 \%$ & 0.25 & No Data \\
\hline $\begin{array}{l}\text { BBR-5 Big Blackfoot below Nevada } \\
\text { Creek }\end{array}$ & 27 & 0 & 0 & No Data \\
\hline $\begin{array}{l}\text { BBR-6 Big Blackfoot at } \\
\text { Nevada/Ogden Road }\end{array}$ & 39 & 0 & 0 & $57.2 \mathrm{~F}$ \\
\hline Tributaries & & & & \\
\hline NFK-1 N. Fork above Kleinschmidt & 43 & 0 & 0 & $57.3 *$ \\
\hline NFK-2 N. Fork below Kleinschmidt & 50 & $12 \%$ & 0.14 & $52.2 *$ \\
\hline EFS-3 Lower Kleinschmidt & 48 & $90 \%$ & 2.83 & $54.4 \mathrm{~F}$ \\
\hline CER-4 Lower Chamberlin Cr & 50 & $8 \%$ & 0.16 & $57.3 \mathrm{~F}$ \\
\hline COT-5 Cottonwood Cr & 50 & $-94 \%$ & 3.66 & $58.2 \mathrm{~F}$ \\
\hline WAR-6 Warren Creek & 47 & $19 \%$ & 0.21 & $63.2 \mathrm{~F}$ \\
\hline
\end{tabular}

cc: Don Peters

Dan Hinley, BLM 
Case no. 98-110527.

Washington Animal Disease Diagnostic Laboratory

\begin{tabular}{llllll} 
Site & Species & Age & Tank & Lot \\
\hline Big Blackfoot R. & Rainbow & YOY & NP* $^{*}$ & BBR-1
\end{tabular} Nea mouth

\section{Grades}

\begin{tabular}{|c|c|c|c|c|c|}
\hline Fish & 0 & 1 & 2 & 3 & 4 \\
\hline 1 & 1 & & & & \\
\hline 2 & 1 & & & & \\
\hline 3 & 1 & & & & \\
\hline 4 & & 1 & & & \\
\hline 5 & 1 & & & & \\
\hline 6 & 1 & & & & \\
\hline 7 & 1 & & & & \\
\hline 8 & 1 & & & & \\
\hline 9 & 1 & & & & \\
\hline 10 & & & & 1 & \\
\hline 11 & 1 & & & & \\
\hline 12 & 1 & & & & \\
\hline 13 & 1 & & & & \\
\hline 14 & 1 & & & & \\
\hline 15 & 1 & & & & \\
\hline 16 & 1 & & & & \\
\hline 17 & & & 1 & & \\
\hline 18 & 1 & & & & \\
\hline 19 & 1 & & & & \\
\hline 20 & 1 & & & & \\
\hline 21 & 1 & & & & \\
\hline 22 & 1 & & & & \\
\hline 23 & 1 & & & & \\
\hline 24 & 1 & & & & \\
\hline 25 & 1 & & & & \\
\hline
\end{tabular}

*Not Provided

\section{Comments}

Areas of cartilage lysis containing moderate numbers of $\mathrm{M}$. cerebralis developmental stages but no mature myxospores are in calvarium (most common) and gill arches (less common). Moderate numbers of leukocytes surround and infiltrate lytic areas. \begin{tabular}{cccccc} 
Grade & 0 & 1 & 2 & 3 & 4 \\
\cline { 2 - 5 } & Fish & 3 & 1 & 1 & 0
\end{tabular}

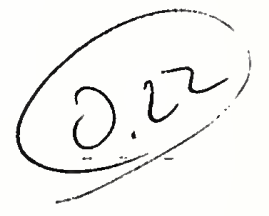

Total fish examined: 36

Percent infected: 14 
Case no. $\underline{98-110528}$

Washington Animal Disease Diagnostic Laboratory

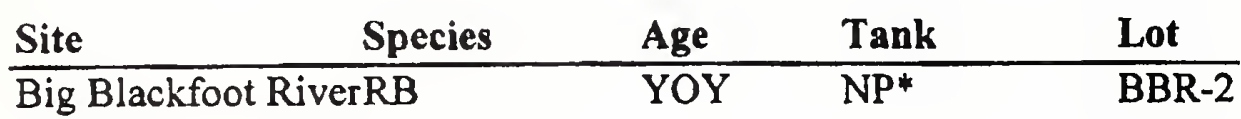

Grades

Grades

\begin{tabular}{|c|c|c|c|c|c|c|c|c|c|c|c|}
\hline Fish & 0 & 1 & 2 & 3 & 4 & Fish & 0 & 1 & 2 & 3 & 4 \\
\hline 1 & 1 & & & & & 26 & 1 & & & & \\
\hline 2 & 1 & & & & & 27 & 1 & & & & \\
\hline 3 & 1 & & & & & 28 & 1 & & & & \\
\hline 4 & 1 & & & & & 29 & & & 1 & & \\
\hline 5 & 1 & & & & & 30 & 1 & & & & \\
\hline 6 & 1 & & & & & 31 & 1 & & & & \\
\hline 7 & 1 & & & & & 132 & 1 & & & & \\
\hline 8 & 1 & & & & & 33 & & & 1 & & \\
\hline 9 & & 1 & & & & 34 & 1 & & & & \\
\hline 10 & 1 & & & & & 35 & 1 & & & & \\
\hline 11 & 1 & & & & & 36 & 1 & & & & \\
\hline 12 & 1 & & & & & 37 & 1 & & & & \\
\hline 13 & & 1 & & & & 38 & 1 & & & & \\
\hline 14 & 1 & & & & & 39 & 1 & & & & \\
\hline 15 & 1 & & & & & 40 & 1 & & & & \\
\hline 16 & 1 & & & & & 41 & 1 & & & & \\
\hline 17 & 1 & & & & & $\overline{42}$ & 1 & & & & \\
\hline 18 & 1 & & & & & 43 & 1 & & & & \\
\hline 19 & & 1 & & & & 44 & 1 & & & & \\
\hline 20 & & & 1 & & & 45 & 1 & & & & \\
\hline 21 & 1 & & & & & 46 & 1 & & & & \\
\hline 22 & 1 & & & & & 47 & 1 & & & & \\
\hline 23 & 1 & & & & & 48 & 1 & & & & \\
\hline 24 & 1 & & & & & & & & & & \\
\hline 25 & & 1 & & & & & & & & & \\
\hline
\end{tabular}

Total fish examined: 48

Percent infected: 15

*Not Provided

\section{Comments}

Areas of cartilage lysis are small and seen in calvarium and less commonly in gill arches. Some foci have no associated inflammatory cells while others have moderate numbers of bordering and infiltrative mononuclear leukocytes. Small to moderate numbers of M. cerebralis generative stages, including a few pansporoblasts, are in lytic areas. 
Case no. $\quad \underline{98-110529}$

Washington Animal Disease Diagnostic Laboratory

\begin{tabular}{|c|c|c|c|c|}
\hline Species & Age & Tank & Lot & \\
\hline Big Blackfoot RiverRB & YOY & $\mathrm{NP}^{*}$ & $\overline{\text { BBR-3 }}$ & $\begin{array}{l}\text { Monee Ruer } \\
\text { Ruper }\end{array}$ \\
\hline
\end{tabular}

Grades

Grades

\begin{tabular}{|c|c|c|c|c|c|c|c|c|c|c|c|}
\hline Fish & 0 & 1 & 2 & 3 & 4 & Fish & 0 & 1 & 2 & 3 & 4 \\
\hline 1 & & 1 & & & & 26 & & & 1 & & \\
\hline 2 & & 1 & & & & 27 & & & & 1 & \\
\hline 3 & 1 & & & & & 28 & 1 & & & & \\
\hline 4 & 1 & & & & & 29 & & & & 1 & \\
\hline 5 & & & & & 1 & 30 & & 1 & & & \\
\hline 6 & 1 & & & & & 31 & 1 & & & & \\
\hline 7 & & & 1 & & & 32 & & & 1 & & \\
\hline 8 & 1 & & & & & 33 & 1 & & & & \\
\hline 9 & & & \begin{tabular}{|l|}
1 \\
\end{tabular} & & & 34 & & & 1 & & \\
\hline 10 & & & & & 1 & 35 & 1 & & & & \\
\hline 11 & 1 & & & & & 36 & & 1 & & & \\
\hline 12 & 1 & & & & & 37 & 1 & & & & \\
\hline 13 & & & 1 & & & 38 & 1 & & & & \\
\hline 14 & & & & & 1 & 39 & & & & 1 & \\
\hline 15 & 1 & & & & & 40 & & & 1 & & \\
\hline 16 & & 1 & & & & 41 & & & 1 & & \\
\hline 17 & 1 & & & & & 42 & 1 & & & & \\
\hline 18 & & 1 & & & & & & & & & \\
\hline 19 & 1 & & & & & & & & & & \\
\hline 20 & 1 & & & & & & & & & & \\
\hline 21 & 1 & & & & & & & & & & \\
\hline 22 & 1 & & & & & . & & & & & \\
\hline 23 & & 1 & & & & & & & & & \\
\hline 24 & 1 & & & & & & & & & & \\
\hline 25 & & & 1 & & & & & & & & \\
\hline
\end{tabular}

*Not Provided

\section{Comments}

Multifocal areas of cartilage lysis, bordered and infiltrated by mononuclear leukocytes, are common in the calvarium and gill arches. Moderate numbers of $\mathrm{M}$. cerebralis generative stages, including numerous pansporoblasts, are in lytic areas. Occasional mature myxospores are also noted. 
Case no. $\quad \underline{98-110530}$

Washington Animal Disease Diagnostic Laboratory

Site

Big Blackfoot R.

Species

Age

Tank

Lot

Below North Fork

Grades

Grades

\begin{tabular}{l} 
Fish \\
\hline
\end{tabular}

BBR-4 RFR beloue

larta corit

U,Arter aneretio

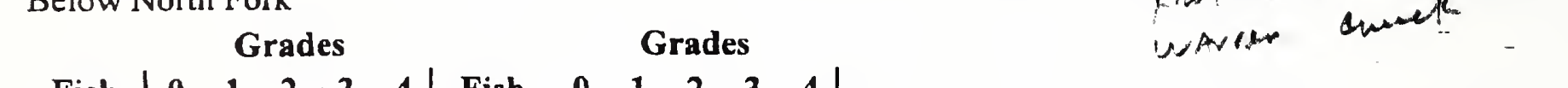

*Not Provided

\section{Comments}

Areas of cartilage lysis are limited to the calvarium. Moderate numbers of $M$. cerebralis generative stages are in lytic areas, but no myxospores are seen. Few to moderate numbers of leukocytes border and infiltrate lytic areas.

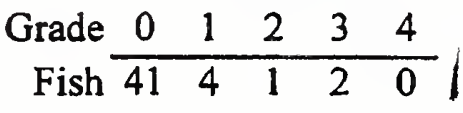

Total fish examined: 48 Percent infected: 15 
Feb-08-99 01:27P WA Anima7 Disease Diag La $5093357424 \quad$ P.02

Case no. $98-110531$

Washington Animal Disease Diagnostic Laboratory

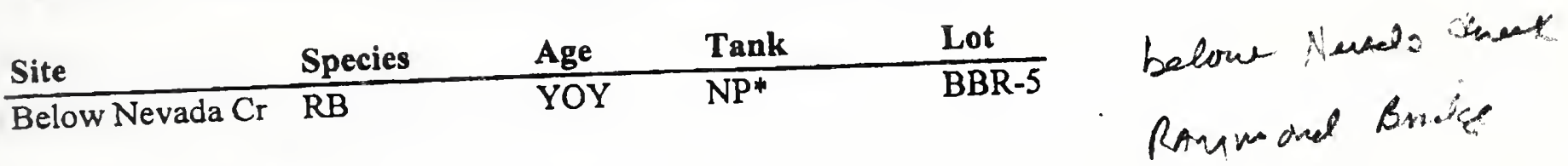

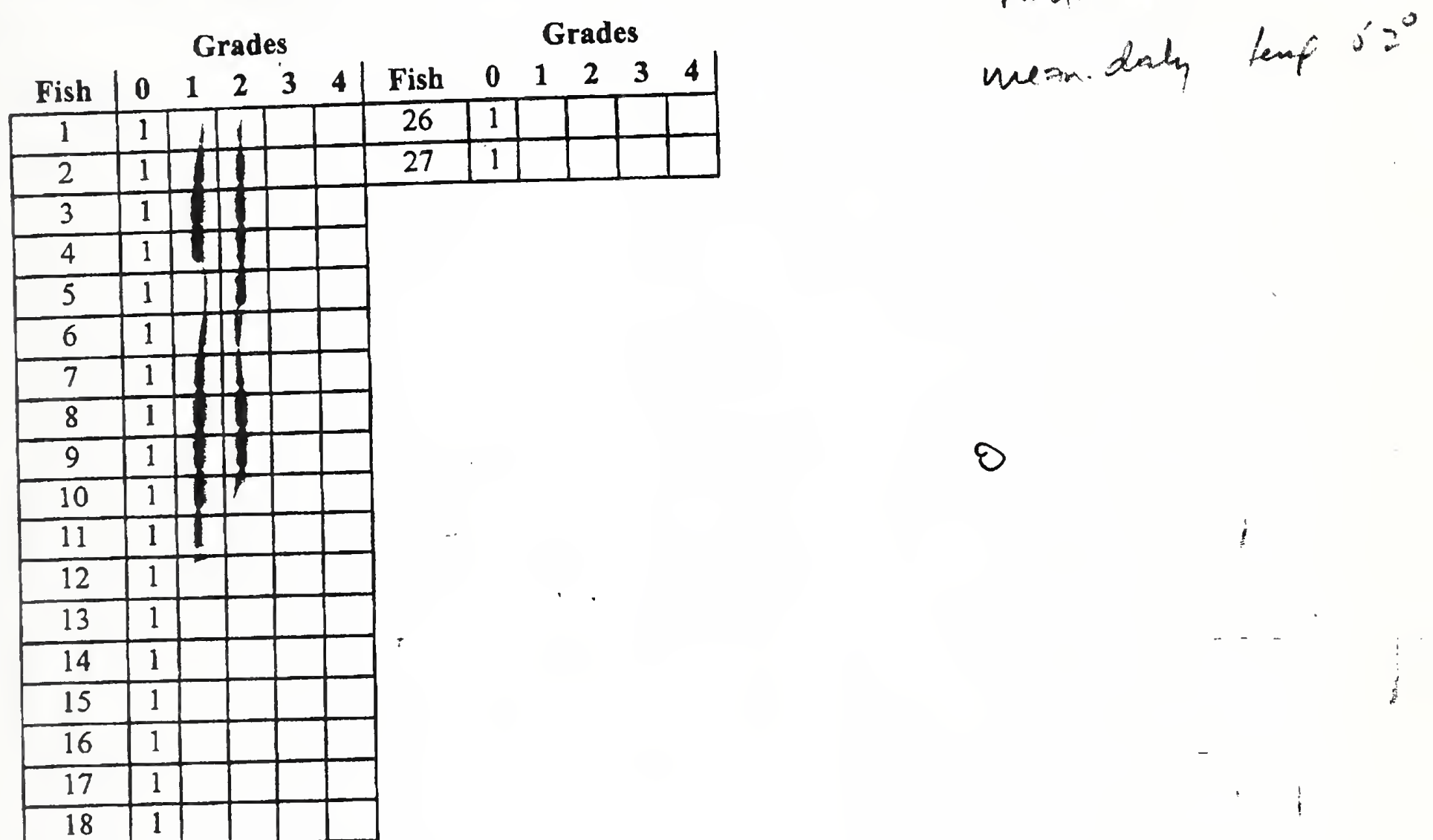

\begin{tabular}{|l|l|l|l|l|l|l|}
\hline 19 & 1 & & & & \\
\hline 20 & 1 & & & & \\
\hline 21 & 1 & & & & \\
\hline 22 & 1 & & & & \\
\hline 23 & 1 & & & & \\
\hline 24 & 1 & & & & \\
\hline 25 & 1 & & & & \\
\hline
\end{tabular}

Summary

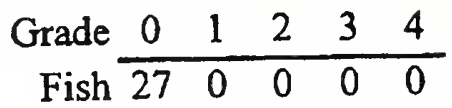

Total fish examined: 27

Percent infected: 0

*Not Provided

\section{Comments}

No cartilaginous lesions suggestive of $M$. cerebralis infection seen. Most fish have peri- and intraneuronal granulocytic cells in cranial and spinal nerves. Significance of these cells in absence of lesions is unknown. 
Case no. $\quad \underline{98-110532}$ Washington Animal Disease Diagnostic Laboratory

Site

Species $\begin{array}{ll}\text { Age } & \text { Tank } \\ \text { YOY } & \mathrm{NP}^{*}\end{array}$

Lot

Grades

\begin{tabular}{|c|c|c|c|c|c|}
\hline Fish & 0 & 1 & 2 & 3 & 4 \\
\hline 1 & 1 & & & & \\
\hline 2 & 1 & & & & \\
\hline 3 & 1 & & & & \\
\hline 4 & 1 & & & & \\
\hline 5 & 1 & & & & \\
\hline 6 & 1 & & & & \\
\hline 7 & 1 & & & & \\
\hline 8 & 1 & & & & \\
\hline 9 & 1 & & & & \\
\hline 10 & 1 & & & & \\
\hline 11 & 1 & & & & \\
\hline 12 & 1 & & & & \\
\hline 13 & 1 & & & & \\
\hline 14 & 1 & & & & \\
\hline 15 & 1 & & & & \\
\hline 16 & 1 & & & & \\
\hline 17 & 1 & & & & \\
\hline 18 & 1 & & & & \\
\hline 19 & 1 & & & & \\
\hline 20 & 1 & & & & \\
\hline 21 & 1 & & & & \\
\hline 22 & 1 & & & & \\
\hline 23 & 1 & & & & \\
\hline 24 & 1 & & & & \\
\hline 25 & 1 & & & & \\
\hline
\end{tabular}

*Not Provided

\section{Comments}

Cartilaginous lesions suggestive of $M$. cerebralis infection are not seen. A mild granulocytic neuritis/perineuritis is present in many fish. 
Case no. $\underline{98-110533}$

Washington Animal Disease Diagnostic Laboratory

\begin{tabular}{|c|c|c|c|c|c|}
\hline Site & Species & Age & Tank & Lot & \\
\hline Big Blackfoot R. & Rainbow & YOY & $\mathrm{NP}^{*}$ & NFK-1 & North Fork \\
\hline
\end{tabular}

\begin{tabular}{|c|c|c|c|c|c|c|c|c|c|c|c|}
\hline \multicolumn{7}{|c|}{ Grades } & \multicolumn{5}{|c|}{ Grades } \\
\hline Fish & 0 & 1 & 2 & 3 & 4 & Fish & 0 & 1 & 2 & 3 & 4 \\
\hline 1 & 1 & & & & & 26 & 1 & & & & \\
\hline 2 & 1 & & & & & 27 & 1 & & & & \\
\hline 3 & 1 & & & & & 28 & 1 & & & & \\
\hline 4 & 1 & & & & & 29 & 1 & & & & \\
\hline 5 & 1 & & & & & 30 & 1 & & & & \\
\hline 6 & 1 & & & & & 31 & 1 & & & & \\
\hline 7 & 1 & & & & & 32 & 1 & & & & \\
\hline 8 & 1 & & & & & 33 & 1 & & & & \\
\hline 9 & 1 & & & & & $\overline{34}$ & 1 & & & & \\
\hline 10 & 1 & & & & & 35 & 1 & & & & \\
\hline 11 & 1 & & & & & 36 & 1 & & & & \\
\hline 12 & 1 & & & & & 37 & 1 & & & & \\
\hline 13 & 1 & & & & & 38 & 1 & & & & \\
\hline 14 & 1 & & & & & 39 & 1 & & & & \\
\hline 15 & 1 & & & & & 40 & 1 & & & & \\
\hline 16 & 1 & & & & & $\overline{41}$ & 1 & & & & \\
\hline 17 & 1 & & & & & 42 & 1 & & & & \\
\hline 18 & 1 & & & & & 43 & 1 & & & & \\
\hline 19 & 1 & & & & & & & & & & \\
\hline 20 & 1 & & & & & & & & & & \\
\hline 21 & 1 & & & & & & & & & & \\
\hline 22 & 1 & & & & & & & & & & \\
\hline 23 & 1 & & & & & & & & & & \\
\hline 24 & 1 & & & & & & & & & & \\
\hline 25 & 1 & & & & & & & & & & \\
\hline
\end{tabular}

Above Kleicuschowet.

\author{
Summary

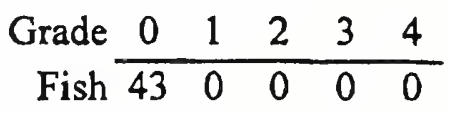 \\ Total fish examined: 43 \\ Percent infectcd: 0
}

\title{
Comments
}

No cartilaginous lesions suggestive of M. cerebralis infection are seen. Most fish have a mild granulocytic neuritis/perineuritis of unknown (doubtful) significance. 
Case no. $\quad \underline{98-110525}$

Site

N.F. Big Blackfoot Rainbow

\section{Grades}

Washington Animal Disease Diagnostic Laboratory

\begin{tabular}{lll} 
Age & Tank & Lot \\
\hline YOY & NP* $^{*}$ & NFK-2
\end{tabular}

Grades

\begin{tabular}{|c|c|c|c|c|c|c|c|c|c|c|c|}
\hline Fish & 0 & 1 & 2 & 3 & 4 & Fish & 0 & 1 & 2 & 3 & 4 \\
\hline 1 & 1 & & & & & 26 & 1 & & & & \\
\hline 2 & 1 & & & & & 27 & 1 & & & & \\
\hline 3 & 1 & & & & & 28 & & & 1 & & \\
\hline 4 & 1 & & & & & 29 & 1 & & & & \\
\hline 5 & 1 & & & & & 30 & 1 & & & & \\
\hline 6 & 1 & & & & & 31 & 1 & & & & \\
\hline 7 & 1 & & & & & 32 & 1 & & & & \\
\hline 8 & & 1 & & & & 33 & 1 & & & & \\
\hline 9 & 1 & & & & & 34 & 1 & & & & \\
\hline 10 & 1 & & & & & 35 & 1 & & & & \\
\hline 11 & 1 & & & & & 36 & 1 & & & & \\
\hline 12 & & 1 & & & & 37 & 1 & & & & \\
\hline 13 & 1 & & & & & 38 & . & 1 & & & \\
\hline 14 & & 1 & & & & 39 & 1 & & & & \\
\hline 15 & 1 & & & & & 40 & 1 & & & & \\
\hline 16 & 1 & & & & & 41 & 1 & & & & \\
\hline 17 & 1 & & & & & 42 & 1 & & & & \\
\hline 18 & 1 & & & & & 43 & 1 & & & & \\
\hline 19 & 1 & & & & & 44 & & 1 & & & \\
\hline 20 & 1 & & & & & 45 & 1 & & & & \\
\hline 21 & 1 & & & & & 46 & 1 & & & & \\
\hline 22 & 1 & & & & & 47 & 1 & & & & \\
\hline 23 & 1 & & & & & 48 & 1 & & & & \\
\hline 24 & 1 & & & & & 49 & 1 & & & & \\
\hline 25 & 1 & & & & & 50 & 1 & & & & \\
\hline
\end{tabular}

*Not Provided

\section{Comments}

Lesions are in ventral calvarium (most common) and gill arches (less common). Lesions consist of areas of cartilage lysis that contain moderate numbers of $M$. cerebralis developmental stages, including pansporoblasts. Few to moderate numbers of leukocytes border lytic foci.

$$
0.64
$$

\section{Summary}

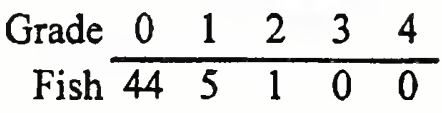

Total fish examined: 50

Percent infected: 12 
Washington Animal Disease Diagnostic Laboratory

\begin{tabular}{lll} 
Age & Tank & Lot \\
\hline YOY & NP* $^{*}$ & LKS-3
\end{tabular}

Case no. $\quad$ 98-110524.

Site

Big Blackfoot RiverRainbow

\section{Grades \\ Grades}

\begin{tabular}{|c|l|l|l|l|l|l|l|l|l|l|l|l|} 
Fish & \multicolumn{1}{|c}{$\mathbf{0}$} & $\mathbf{1}$ & $\mathbf{2}$ & $\mathbf{3}$ & $\mathbf{4}$ & \multicolumn{1}{|c|}{ Fish } & $\mathbf{0}$ & $\mathbf{1}$ & $\mathbf{2}$ & 3 & $\mathbf{4}$ \\
\hline 1 & & & & & 1 & 26 & & & 1 & & \\
\hline 2 & & & & & 1 & 27 & & & & 1 & \\
\hline 3 & & & & & 1 & 28 & & 1 & & & \\
\hline 4 & & & & & 1 & 29 & & & & & 1 \\
\hline 5 & & & & & 1 & 30 & & & & & 1 \\
\hline 6 & & & & 1 & & 31 & & & & 1 & \\
\hline 7 & & & & & 1 & 32 & & & & & 1 \\
\hline 8 & & & 1 & & & 33 & & & & & 1 \\
\hline 9 & & & & & 1 & 34 & & & & & 1 \\
\hline 10 & & & & 1 & & 35 & 1 & & & & \\
\hline 11 & & & & & 1 & 36 & & & 1 & & \\
\hline 12 & & & & & 1 & 37 & & & & 1 & \\
\hline 13 & & & & & 1 & 38 & & & & & 1 \\
\hline 14 & & & 1 & & & 39 & & & & 1 & \\
\hline 15 & & & & 1 & & 40 & & 1 & & & \\
\hline 16 & & & & & 1 & 41 & 1 & & & & \\
\hline 17 & & & & & 1 & 42 & & & & & 1 \\
\hline 18 & & & & 1 & & 43 & & & & 1 & \\
\hline 19 & & & & 1 & & 44 & & 1 & & & \\
\hline 20 & & & & 1 & & 45 & & & & 1 & \\
\hline 21 & & & 1 & & & 46 & & & 1 & & \\
\hline 22 & 1 & & & & & 47 & 1 & & & & \\
\hline 23 & & & 1 & & & 48 & 1 & & & & \\
\hline 24 & & & & 1 & & & & & \\
\hline 25 & & & & & 1 & & & & & \\
\hline
\end{tabular}

* Not Provided

\section{Comments}

Multifocal to coalescing areas of catilage necrosis bordered and infiltrated by moderate numbers of leukocytes are common in calvarium and gill arches. In lytic areas are moderate to large numbers of $\mathrm{M}$. cerebralis generative stages, including numerous pansporoblasts.

\begin{abstract}
\begin{tabular}{cccccc} 
Grade & 0 & 1 & 2 & 3 & 4 \\
\cline { 2 - 5 } & Fish & 5 & 3 & 13 & 20
\end{tabular}
\end{abstract}
Total fish examined: 48

Percent infected: 90 
Case no. $\underline{98-110522}$

Washington Animal Disease Diagnostic Laboratory

\begin{tabular}{lllll} 
Site & Species & Age & Tank & Lot \\
\hline Chamberland $\mathrm{Cr}$ & $\mathrm{RB}$ & YOY & $\mathrm{NP}^{*}$ & $\mathrm{CCR}-4$
\end{tabular} ne worth

Grades

Grades

\begin{tabular}{|l|l|l|l|l|l|l|l|l|l|l|l|l|} 
Fish & \multicolumn{1}{|c}{$\mathbf{0}$} & $\mathbf{1}$ & $\mathbf{2}$ & $\mathbf{3}$ & $\mathbf{4}$ & \multicolumn{1}{|l}{ Fish } & $\mathbf{0}$ & $\mathbf{1}$ & $\mathbf{2}$ & $\mathbf{3}$ & $\mathbf{4}$ \\
\hline 1 & 1 & & & & & 26 & $\mathbf{1}$ & & & & \\
\hline 2 & 1 & & & & & 27 & 1 & & & & \\
\hline 3 & 1 & & & & & 28 & 1 & & & & \\
\hline 4 & 1 & & & & & 29 & 1 & & & & \\
\hline 5 & 1 & & & & & 30 & 1 & & & & \\
\hline 6 & 1 & & & & & 31 & 1 & & & & \\
\hline 7 & 1 & & & & & 32 & 1 & & & & \\
\hline 8 & 1 & & & & & 33 & 1 & & & & \\
\hline 9 & 1 & & & & & 34 & 1 & & & & \\
\hline 10 & 1 & & & & & 35 & & & 1 & & \\
\hline 11 & 1 & & & & & 36 & 1 & & & & \\
\hline 12 & & & & 1 & & 37 & 1 & & & & \\
\hline 13 & 1 & & & & & 38 & 1 & & & & \\
\hline 14 & 1 & & & & & 39 & 1 & & & & \\
\hline 15 & & & 1 & & & 40 & 1 & & & & \\
\hline 16 & 1 & & & & & 41 & 1 & & & & \\
\hline 17 & 1 & & & & & 42 & 1 & & & & \\
\hline 18 & 1 & & & & & 43 & 1 & & & & \\
\hline 19 & 1 & & & & & 44 & & 1 & & & \\
\hline 20 & 1 & & & & & 45 & 1 & & & & \\
\hline 21 & 1 & & & & & 46 & 1 & & & & \\
\hline 22 & 1 & & & & & 47 & 1 & & & & \\
\hline 23 & 1 & & & & & 48 & 1 & & & & \\
\hline 24 & 1 & & & & & 49 & 1 & & & & \\
\hline 25 & 1 & & & & & 50 & 1 & & & & \\
\hline
\end{tabular}

0.16

*Not Provided

\section{Comments}

Lesions are confined to calvarium (all fish) Ind gill arches (one fish) and consist of areas of lysis with moderate numbers of $\mathrm{M}$. cerebralls generative stages, including pansporoblasts. Large numbers of leukocytes typically border and infiltrate lytic foci. 
Case no. $\quad \underline{98-110523}$

Washington Animal Disease Diagnostic Laboratory

\begin{tabular}{lllll} 
Site & Species & Age & Tank & Lot \\
\hline Cottonwood Creek Rainbow & YOY & NP* $^{*}$ & COT-5
\end{tabular} mouth

\begin{tabular}{|c|c|c|c|c|c|c|c|c|c|c|c|}
\hline \multicolumn{7}{|c|}{ Grades } & \multicolumn{5}{|c|}{ Grades } \\
\hline Fish & 0 & 1 & 2 & 3 & 4 & Fish & 0 & 1 & 2 & 3 & 4 \\
\hline 1 & & & & & 1 & 26 & & & & & 1 \\
\hline 2 & & & & & 1 & 27 & 1 & & & & \\
\hline 3 & & & & & 1 & 28 & & & & & 1 \\
\hline 4 & & & & & 1 & 29 & & & & & 1 \\
\hline 5 & & & & & 1 & 30 & & 1 & & & \\
\hline 6 & & & & & 1 & 31 & & & & & 1 \\
\hline 7 & & & & & 1 & 32 & & & & & 1 \\
\hline 8 & & & & & 1 & 33 & 1 & & & & \\
\hline 9 & & & & & 1 & 34 & & & & & 1 \\
\hline 10 & & & & & 1 & 35 & & & & & 1 \\
\hline 11 & & & & & 1 & 36 & & & & 1 & \\
\hline 12 & & & & & 1 & 37 & & & & & 1 \\
\hline 13 & & & & & 1 & 38 & & & & & 1 \\
\hline 14 & & & & & 1 & 39 & & & & & 1 \\
\hline 15 & & & & & 1 & 40 & & & & & 1 \\
\hline 16 & & & & & 1 & 41 & & & & & 1 \\
\hline 17 & & & & & 1 & 42 & & & & & 1 \\
\hline 18 & & & & & 1 & 43 & & & & & 1 \\
\hline 19 & & & & & 1 & 44 & & & & & 1 \\
\hline 20 & & & & & 1 & 45 & & & & & 1 \\
\hline 21 & & & & & 1 & 46 & & & & & 1 \\
\hline 22 & & & & & 1 & 47 & & & & & 1 \\
\hline 23 & & & & & 1 & 48 & 1 & & & & \\
\hline 24 & & & & & 1 & 49 & & & & & 1 \\
\hline 25 & & & & & 1 & 50 & & & & 1 & \\
\hline
\end{tabular}

*Not Provided

\section{Comments}

Multifocal to coalescing, often locally extensive areas of cartilage necrosis are in calvarium, gill arches, and less commonly other cartilages. In lytic areas are large numbers of $M$. cerebralis developmental stages, including numerous pansporoblasts. Numerous leukocytes surround and infiltrate lytic foci. 
Jan-22-99 02:41P WA Anima 7 Disease Diag La 5093357424

Case no. $\quad \underline{98-110521}$

Washington Animal Disease Diagnostic Laboratory

\begin{tabular}{lllll} 
Site & Species & Age & Tank & Lot \\
\hline Warrin Creek & RBT & YOY & & WAR-6
\end{tabular}

\begin{tabular}{|c|c|c|c|c|c|c|c|c|c|c|c|}
\hline \multicolumn{7}{|c|}{ Grades } & \multicolumn{5}{|c|}{ Grades } \\
\hline Fish & 0 & 1 & 2 & 3 & 41 & Fish & 0 & 1 & 2 & $\mathbf{3}$ & 4 \\
\hline 1 & 1 & & & & & 26 & 1 & & & & \\
\hline 2 & 1 & & & & & 27 & 1 & & & & \\
\hline 3 & 1 & & & & & 28 & 1 & & & & \\
\hline 4 & 1 & & & & & 29 & 1 & & & & \\
\hline 5 & & 1 & & & & 30 & & 1 & & & \\
\hline 6 & & 1 & & & & 31 & 1 & & & & \\
\hline 7 & 1 & & & & & 32 & 1 & & & & \\
\hline 8 & 1 & & & & & 33 & 1 & & & & \\
\hline 9 & 1 & & & & & 34 & & 1 & & & \\
\hline 10 & 1 & & & & & 35 & 1 & & & & \\
\hline 11 & 1 & & & & & 36 & 1 & & & & \\
\hline 12 & 1 & & & & & 37 & 1 & & & & \\
\hline 13 & & 1 & & & & 38 & 1 & & & & \\
\hline 14 & 1 & & & & & 39 & 1 & & & & \\
\hline 15 & 1 & & & & & 40 & 1 & & & & \\
\hline 16 & & & 1 & & & 41 & & 1 & & & \\
\hline 17 & 1 & & & & & 42 & 1 & & & & \\
\hline 18 & 1 & & & & & 43 & 1 & & & & \\
\hline 19 & & 1 & & & & 44 & 1 & & & & \\
\hline 20 & 1 & & & & & 45 & 1 & & & & \\
\hline 21 & 1 & & & & & 46 & & 1 & & & \\
\hline 22 & 1 & & & & & 47 & 1 & & & & \\
\hline 23 & 1 & & & & & & & & & & \\
\hline 24 & 1 & & & & & & & & & & \\
\hline 25 & 1 & & & & & & & & & & \\
\hline
\end{tabular}

*Not Provided

\section{Comments}

Areas of cartilage lysis are limited to the calvarium and occasional gill arches. In lytic areas there are moderate numbers of $\mathrm{M}$. cerebralis generative stages and fewer pansporoblasts. Rare free mature myxospores are seen. Few to moderate numbers of leukocytes border and infiltrate lytic areas. 


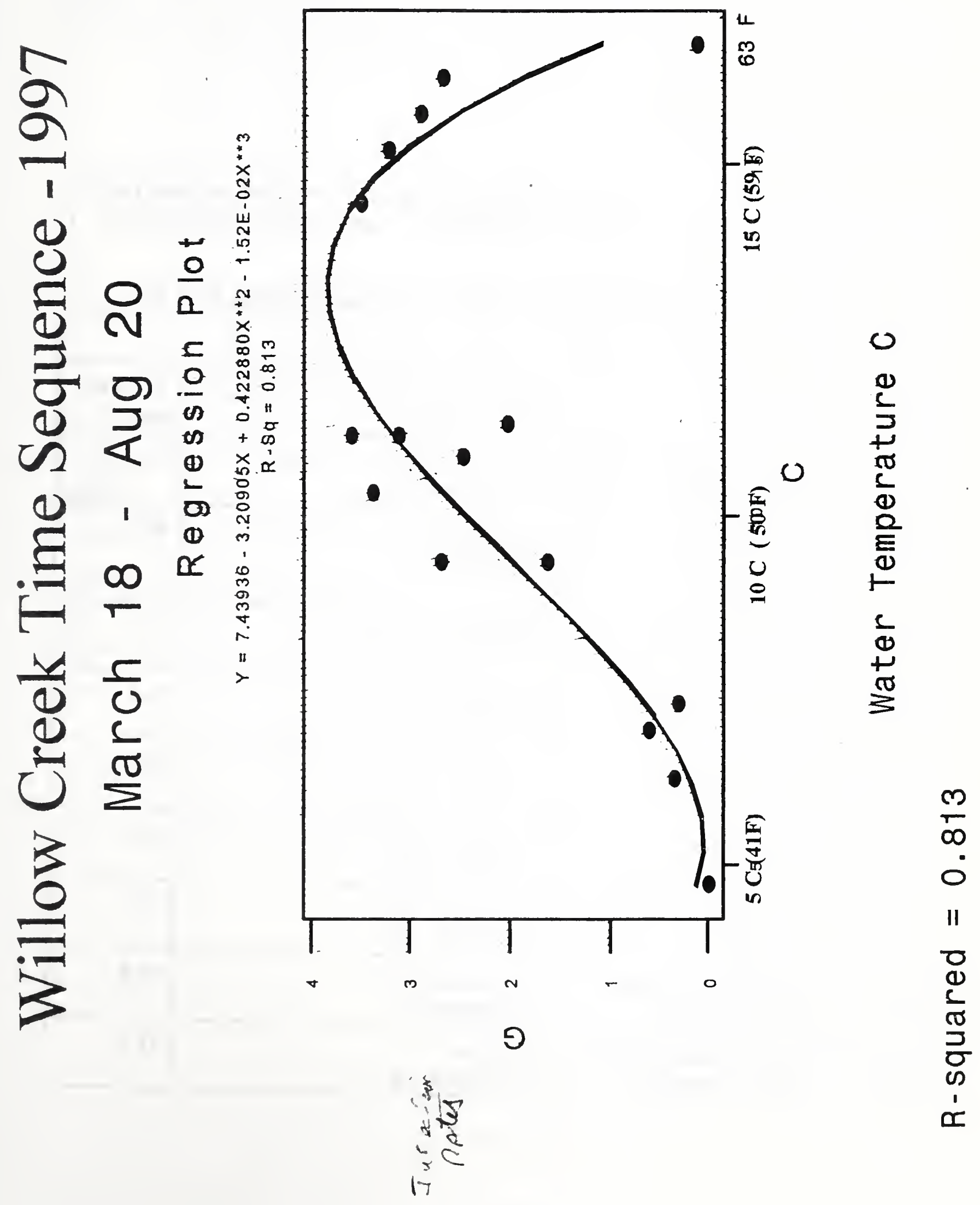




\section{Ron Pierce \\ MFWP}

Dear Ron,

Enclosed is what histological data that I have available from the Washington State Lab. Everything has returned from the July - August sentinel cages. Table 1 shows the histo data through this period.

Table 1. Histological data from sentinel cages placed in the Big Blackfoot River and selected tributaries for 1999 .

\begin{tabular}{|l|l|l|l|}
\hline Date & Location & $\begin{array}{l}\text { Histological Data } \\
5 \text { scale }\end{array}$ & $\begin{array}{l}\text { Av. Water } \\
\text { temp F }\end{array}$ \\
\hline $\begin{array}{l}\text { July 14- } \\
24\end{array}$ & $\begin{array}{l}\text { Big Blackfoot below Elk } \\
\text { Cr BBR-1-99 }\end{array}$ & $\begin{array}{l}\text { Av Grade }=0.52 \\
\% \text { infected }=42\end{array}$ & 61.2 \\
\hline $\begin{array}{l}\text { July 14- } \\
24\end{array}$ & $\begin{array}{l}\text { Big Blackfoot above the } \\
\text { Clearwater River } \\
\text { BBR-2-99 }\end{array}$ & $\begin{array}{l}\text { Av Grade }=0.22 \\
\% \text { infected }=17\end{array}$ \\
\hline July 1-11 & $\begin{array}{l}\text { lower Kleinschmidt } \\
\text { LKS-1-99 }\end{array}$ & $\begin{array}{l}\text { Av Grade }=0.3 .56 \\
\% \text { infected }=90\end{array}$ & 58.2 \\
\hline July 1-11 & $\begin{array}{l}\text { Chamberlain Cr } \\
\text { CCR-2-99 }\end{array}$ & $\begin{array}{l}\text { Av Grade }=2.71 \\
\% \text { infected }=93\end{array}$ & 56.5 \\
\hline July 1-11 & $\begin{array}{l}\text { Cottonwood Cr } \\
\text { COT-3-99 }\end{array}$ & $\begin{array}{l}\text { Av Grade }=4.72 \\
\% \text { infected }=98\end{array}$ \\
\hline July 1-11 & $\begin{array}{l}\text { Warren Cr } \\
\text { WAR-4-99 }\end{array}$ & $\begin{array}{l}\text { Av Grade }=2.10 \\
\% \text { infected }=84\end{array}$ & 54.6 \\
\hline $\begin{array}{l}\text { Aug 19- } \\
29\end{array}$ & $\begin{array}{l}\text { Chamberlain Cr mouth } \\
\text { CCR99-5S }\end{array}$ & $\begin{array}{l}\text { Av Grade }=0.90 \\
\% \text { infected }=55\end{array}$ & $\mathbf{6 2 . 1}$ \\
\hline $\begin{array}{l}\text { Aug 19- } \\
29\end{array}$ & $\begin{array}{l}\text { E Fk Chamberlain Cr } \\
\text { EFCCR-99-1S }\end{array}$ & $\begin{array}{l}\text { Av Grade }=0.00 \\
\% \text { infected }=0\end{array}$ \\
\hline $\begin{array}{l}\text { Aug 19- } \\
29\end{array}$ & $\begin{array}{l}\text { W Fk Chamberlin Cr } \\
\text { WFKCCR-99-1S }\end{array}$ & $\begin{array}{l}\text { Av Grade }=0 \\
\% \text { infected }=0\end{array}$ & 51.2 \\
\hline
\end{tabular}




\section{9- Big Blackfoot River and Tributaries}

\begin{tabular}{|c|c|c|c|}
\hline Date & River Stations & Tributary Stations & Kill Date \\
\hline July 1 - 11 & $\begin{array}{l}\text { BBR-1 Below Elk Cr } \\
\text { BBR-2 Above Clearwater R }\end{array}$ & $\begin{array}{l}\text { LKS-1 lower Kleinschmidt } \\
\text { CCR-2 Chamberlain Cr } \\
\text { COT-3 Cottonwood Cr } \\
\text { WAR-4 Warren Cr }\end{array}$ & 9/28/99 \\
\hline Aug 1929 & Spatial & $\begin{array}{l}\text { CCR99- 5S Chamberlin Cr mouth } \\
\text { EFCCR99-1S E. FK Chamberlin Cr } \\
\text { WFCCR99- 1S W FK Chamberlin Cr }\end{array}$ & \\
\hline Sept 1- 10 & $\begin{array}{l}\text { BBR- } 3 \text { near mouth } \\
\text { BBR }-4 \text { below Elk Cr } \\
\text { BBR - } 5 \text { above Clearwater R } \\
\text { BBR - } 6 \text { below N. Fork } \\
\text { BBR - } 7 \text { below Nevada Cr } \\
\text { BBR - } 8 \text { Nevada/Ogden Rd } \\
\end{array}$ & $\begin{array}{l}\text { Elk - } 5 \text { Elk Cr @Sunset Hill Rd } \\
\text { Rock - 9 Rock Cr mouth } \\
\text { LKS -10 Kleinschmidt Cr mouth } \\
\text { MT - } 10 \text { Monture Cr mouth } \\
\text { Rat - } 11 \text { Rattlesnake Cr mouth }\end{array}$ & \\
\hline $\begin{array}{l}\text { Aug 29- } \\
\text { Sept } 8 \\
\end{array}$ & Time Sequence & $\begin{array}{l}\text { CCR99- } 6 \text { Below the mouth of } \\
\text { the East Fork }\end{array}$ & \\
\hline Sept 8- 18 & Time Sequence & $\begin{array}{l}\text { CCR99- } 7 \text { Below the mouth of } \\
\text { the East Fork }\end{array}$ & \\
\hline $\begin{array}{l}\text { Sept } 18- \\
28\end{array}$ & Time Sequence & $\begin{array}{l}\text { CCR99- } 8 \text { Below the mouth of } \\
\text { the East Fork }\end{array}$ & \\
\hline & & & \\
\hline & & & \\
\hline & & & \\
\hline & & & \\
\hline & & & \\
\hline
\end{tabular}




\section{Big Blackfoot River and Selected Tributaries}

Comparison of Infection Intensities between 1998-1999

\begin{tabular}{|c|c|c|}
\hline Location & Hitological Data-1998 & Hitological Data-1999 \\
\hline Big Blackfoot below Elk Cr & $\begin{array}{l}\text { Av Infection }=0.21 \\
\text { Av water temp }=62.0 ?\end{array}$ & $\begin{array}{l}\text { Av Infection }=0.52 \\
\text { Av water temp }=61.2\end{array}$ \\
\hline Big Blackfoot above Clearwater $\mathbf{R}$. & $\begin{array}{l}\text { Av Infection }=1.10 \\
\text { Av water temp }=63.0\end{array}$ & $\begin{array}{l}\text { Av Infection }=0.22 \\
\text { Av water temp }=58.2\end{array}$ \\
\hline Lower Kleinschmidt $\mathbf{C r}$ & $\begin{array}{l}\text { Av Infection }=\mathbf{2 . 8 3} \\
\text { Av water temp }=\mathbf{5 4 . 4}\end{array}$ & $\begin{array}{l}\text { Av Infection }=3.56 \\
\text { Av water temp }=52.5\end{array}$ \\
\hline Lower Chamberlain $\mathrm{Cr}$ & $\begin{array}{l}\text { Av Infection }=0.16 \\
\text { Av water temp }=57.3\end{array}$ & $\begin{array}{l}\text { Av Infection }=2.71 \\
\text { Av water temp }=56.9\end{array}$ \\
\hline Cottonwood Cr & $\begin{array}{l}\text { Av Infection }=3.66 \\
\text { Av water temp }=58.2\end{array}$ & $\begin{array}{l}\text { Av Infection }=4.72 \\
\text { Av water temp }=54.6\end{array}$ \\
\hline Warren $\mathrm{Cr}$ & $\begin{array}{l}\text { Av Infection }=0.21 \\
\text { Av water temp }=63.2\end{array}$ & $\begin{array}{l}\text { Av Infection }=2.10 \\
\text { Av water temp }=61.1\end{array}$ \\
\hline
\end{tabular}


Big Blackfoot River - 1999

Highest 4 day mean daily avg.

Mean daily for period

BBR-1 (BELOW Elk Cr.)(Repeat)

BBR-5 (ABOVE CLEARWATER R.)

\begin{tabular}{|c|c|c|c|}
\hline & & & \\
\hline $07 / 14 / 1999$ & 61.9 & 59.1 & \\
\hline $07 / 15 / 1999$ & 58.5 & 56.3 & \\
\hline $07 / 16 / 1999$ & 56.2 & 53.8 & \\
\hline $07 / 17 / 1999$ & 57.1 & 54.3 & \\
\hline 07/18/1999 & 59.1 & 56.0 & \\
\hline 07/19/1999 & 60.5 & 57.7 & \\
\hline 07/20/1999 & 61.8 & 59.9 & \\
\hline 07/21/1999 & 60.6 & 58.8 & \\
\hline $07 / 22 / 1999$ & 60.4 & 57.4 & \\
\hline
\end{tabular}

\begin{tabular}{lllll} 
& \multicolumn{4}{c}{ MEAN } \\
61.2 & $09 / 04 / 1999$ & 52.8 & 49.9 & 55.5 \\
59.6 & $09 / 05 / 1999$ & 55.0 & 51.6 & 58.3 \\
& $09 / 06 / 1999$ & 56.9 & 55.5 & 58.6 \\
& $09 / 07 / 1999$ & 53.8 & 51.6 & 56.1 \\
& $09 / 08 / 1999$ & 53.0 & 49.4 & 56.1 \\
& $09 / 09 / 1999$ & 54.1 & 50.8 & 56.9 \\
& $09 / 10 / 1999$ & 57.1 & 55.0 & 59.5 \\
& $09 / 11 / 1999$ & 54.1 & 51.6 & 56.9 \\
& $09 / 12 / 1999$ & 52.3 & 49.1 & 54.7
\end{tabular}

BBR-2 (ABOVE CLEARWATER R.) MEAN MIN MAX

$\begin{array}{llll}07 / 14 / 1999 & 60.0 & 56.1 & 62.9 \\ 07 / 15 / 1999 & 56.4 & 53.9 & 60.6 \\ 07 / 16 / 1999 & 53.8 & 50.8 & 56.4 \\ 07 / 17 / 1999 & 55.1 & 51.6 & 58.6 \\ 07 / 18 / 1999 & 57.2 & 53.3 & 61.4 \\ 07 / 19 / 1999 & 58.8 & 54.7 & 62.6 \\ 07 / 20 / 1999 & 60.2 & 56.9 & 62.3 \\ 07 / 21 / 1999 & 58.8 & 55.8 & 61.4 \\ 07 / 22 / 1999 & 58.7 & 54.7 & 62.6\end{array}$

BBR-3 (NEAR MOUTH) Lost fish

MEAN MIN MAX

$\begin{array}{llll}09 / 04 / 1999 & 54.7 & 53.1 & 56.8 \\ 09 / 05 / 1999 & 57.0 & 55.4 & 58.4 \\ 09 / 06 / 1999 & 56.4 & 48.7 & 59.3 \\ 09 / 07 / 1999 & 55.9 & 41.4 & 76.0 \\ 09 / 08 / 1999 & 55.8 & 54.0 & 57.6 \\ 09 / 09 / 1999 & 55.2 & 54.0 & 56.8 \\ 09 / 10 / 1999 & 57.1 & 56.2 & 58.7 \\ 09 / 11 / 1999 & 57.2 & 56.2 & 58.4 \\ 09 / 12 / 1999 & 54.7 & 52.9 & 56.8\end{array}$

BBR-4 (BELOW ELK CR.)

\begin{tabular}{|c|c|c|c|}
\hline & $N$ & MIN & MAX \\
\hline 9/04/1999 & 54.5 & 52.3 & 56.5 \\
\hline 999 & 56.2 & 53.4 & 59.3 \\
\hline $9 / 0$ & 58.1 & 56.8 & .2 \\
\hline 9 & 55.5 & J. & o. \\
\hline 99 & 54.2 & 51.2 & 57.0 \\
\hline & 55.2 & 52 & 57.6 \\
\hline & 58.1 & 56.2 & 61.0 \\
\hline & 5.8 & 53.4 & 58. \\
\hline 99 & 53. & 50.9 & 56 \\
\hline
\end{tabular}

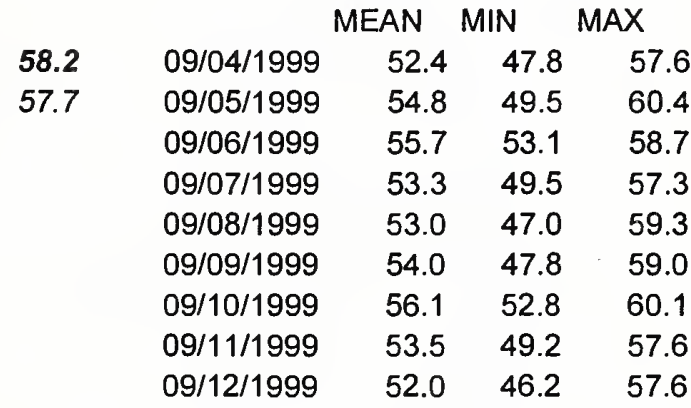

\section{BBR-6 (BELOW N.FK.)}

MEAN MIN MAX

BBR-7 (BELOW NEVEDA CR.)

\begin{tabular}{|c|c|c|c|c|c|}
\hline & & EAN & MIN & MAX & \\
\hline 56.9 & $09 / 04 / 1999$ & 52.9 & 48.2 & 58.0 & 57.1 \\
\hline \multirow{8}{*}{56.0} & 09/05/1999 & 56.1 & 51.0 & 61.7 & 55.7 \\
\hline & $09 / 06 / 1999$ & 58.2 & 55.8 & 62.8 & \\
\hline & 09/07/1999 & 55.8 & 52.4 & 60.9 & \\
\hline & 09/08/1999 & 54.8 & 49.4 & 61.1 & \\
\hline & 09/09/1999 & 55.8 & 49.9 & 61.7 & \\
\hline & 09/10/1999 & 58.1 & 54.7 & 63.1 & \\
\hline & $09 / 11 / 1999$ & 55.7 & 51.9 & 60.9 & \\
\hline & $09 / 12 / 1999$ & 53.6 & 48.2 & 59.7 & \\
\hline
\end{tabular}

BBR-8 (NEVEDA/OGDEN RD.)

$\begin{array}{llllll}\mathbf{5 7 . 1} & 09 / 04 / 1999 & 50.8 & 47.1 & 56.0 & \mathbf{5 2 . 8}\end{array}$

$\begin{array}{llllll}55.7 & 09 / 05 / 1999 & 52.9 & 48.7 & 57.9 & 51.5\end{array}$

$09 / 06 / 1999 \quad 53.7 \quad 51.2 \quad 57.4$

$09 / 07 / 1999 \quad 51.0 \quad 48.2 \quad 54.6$

$09 / 08 / 1999 \quad 50.7 \quad 46.2 \quad 55.4$

$09 / 09 / 1999 \quad 51.7 \quad 47.3 \quad 56.2$

09/10/1999 $53.1 \quad 50.7 \quad 56.5$

$09 / 11 / 1999 \quad 50.6 \quad 47.9 \quad 53.5$

$\begin{array}{llll}09 / 12 / 1999 & 49.4 & 45.1 & 53.7\end{array}$

55.1

53.9

5.1

5.7 
TRIBUTARIES OF BLACKFOOT RIVER - 1999 1ST AND LAST DAY TEMPS. FOR PERIOD NOT INCLUDED HIGHEST 4 MEAN DAILY AVG I MEAN AVG.

\begin{tabular}{|c|c|c|c|}
\hline \multicolumn{4}{|c|}{ LKS-1 (LOWER KLEINSCHMIDT) } \\
\hline \multicolumn{2}{|c|}{ MEAN } & MIN & MAX \\
\hline 07/02/1999 & 49.4 & 45.5 & 54.4 \\
\hline 07/03/1999 & 50.6 & 45.8 & 58.0 \\
\hline $07 / 04 / 1999$ & 48.9 & 46.9 & 52.7 \\
\hline $07 / 05 / 1999$ & 51.8 & 46.0 & 60.0 \\
\hline $07 / 06 / 1999$ & 52.7 & 45.8 & 61.4 \\
\hline $07 / 07 / 1999$ & 52.0 & 47.4 & 59.4 \\
\hline $07 / 08 / 1999$ & 51.0 & 45.8 & 59.1 \\
\hline 07/09/1999 & 52.5 & 45.8 & 61.1 \\
\hline $07 / 10 / 1999$ & 53.0 & 46.6 & 61.4 \\
\hline
\end{tabular}

CCR-2 (CHAMBERLIN CR.)

MEAN MIN MAX

$07 / 02 / 1999 \quad 51.2 \quad 47.6 \quad 54.9$

$07 / 03 / 1999 \quad 52.5 \quad 47.1 \quad 59.1$

$\begin{array}{lllll}07 / 04 / 1999 & 51.8 & 49.8 & 55.2\end{array}$

$\begin{array}{llll}07 / 05 / 1999 & 53.1 & 47.3 & 60.8\end{array}$

$\begin{array}{llll}07 / 06 / 1999 & 55.4 & 48.7 & 67.1\end{array}$

$\begin{array}{llll}07 / 07 / 1999 & 56.7 & 50.1 & 69.4\end{array}$

$07 / 08 / 1999 \quad 55.9 \quad 49.6 \quad 65.1$

$\begin{array}{lllll}07 / 09 / 1999 & 56.7 & 46.0 & 72.1\end{array}$

$\begin{array}{llll}07 / 10 / 1999 & 58.3 & 48.7 & 72.1\end{array}$

\begin{tabular}{|c|c|c|c|}
\hline \multicolumn{4}{|c|}{ COT-3 (COTTONWOOD CR.) } \\
\hline & MEAN & MIN & MAX \\
\hline $07 / 02 / 1999$ & 49.5 & 45.8 & 52.7 \\
\hline 07/03/1999 & 50.7 & 45.8 & 55.8 \\
\hline $07 / 04 / 1999$ & 49.5 & 47.8 & 52.7 \\
\hline $07 / 05 / 1999$ & 51.2 & 45.8 & 58.0 \\
\hline 07/06/1999 & 53.8 & 48.0 & 60.0 \\
\hline $07 / 07 / 1999$ & 54.1 & 50.5 & 57.7 \\
\hline 07/08/1999 & 53.5 & 48.6 & 59.1 \\
\hline 07/09/1999 & 54.7 & 49.1 & 60.6 \\
\hline $07 / 10 / 1999$ & 55.9 & 50.5 & 61.7 \\
\hline
\end{tabular}

WAR-4 (WARREN CR.)

MEAN MIN MAX

$\begin{array}{llll}07 / 02 / 1999 & 54.2 & 49.9 & 58.0\end{array}$

$\begin{array}{llll}07 / 03 / 1999 & 55.3 & 49.3 & 61.4\end{array}$

$\begin{array}{llll}07 / 04 / 1999 & 55.3 & 53.0 & 59.1\end{array}$

$07 / 05 / 1999 \quad 56.2 \quad 49.6 \quad 64.6$

$\begin{array}{llll}07 / 06 / 1999 & 60.1 & 52.7 & 68.1\end{array}$

$07 / 07 / 1999 \quad 61.4 \quad 58.0 \quad 65.2$

$\begin{array}{llll}07 / 08 / 1999 & 57.8 & 52.1 & 64.0\end{array}$

$\begin{array}{llll}07 / 09 / 1999 & 60.2 & 53.3 & 67.8\end{array}$

$\begin{array}{llll}07 / 10 / 1999 & 62.7 & 56.3 & 69.3\end{array}$

\begin{tabular}{|c|c|c|c|c|}
\hline \multicolumn{5}{|c|}{ CCR99-5S (CHAMBERLIN CR.) } \\
\hline & MEAN & VIN & MAX & \\
\hline $08 / 20 / 1999$ & 62.4 & 56.0 & 69.2 & 62.3 \\
\hline $08 / 21 / 1999$ & 62.3 & 56.6 & 68.9 & 61.2 \\
\hline $08 / 22 / 1999$ & 62.3 & 56.8 & 68.3 & \\
\hline $08 / 23 / 1999$ & 60.9 & 55.4 & 66.5 & \\
\hline $08 / 24 / 1999$ & 59.8 & 56.0 & 64.2 & \\
\hline $08 / 25 / 1999$ & 58.8 & 55.2 & 63.4 & \\
\hline $08 / 26 / 1999$ & 61.6 & 56.3 & 68.0 & \\
\hline $08 / 27 / 1999$ & 62.0 & 57.1 & 67.7 & \\
\hline $08 / 28 / 1999$ & 60.8 & 59.4 & 62.8 & \\
\hline
\end{tabular}

56.9

61.1

58.1
EFKCCR99-1S (E. FK. CHAMBERLIN CR.) MEAN MIN MAX

$\begin{array}{llllll}52.5 & 08 / 20 / 1999 & 54.7 & 49.1 & 61.7 & \mathbf{5 5 . 0}\end{array}$

$\begin{array}{llllll}51.3 & 08 / 21 / 1999 & 54.5 & 48.8 & 61.7 & 54.2\end{array}$

$08 / 22 / 1999 \quad 54.2 \quad 49.1 \quad 61.2$

$08 / 23 / 1999 \quad 52.7 \quad 47.2 \quad 59.5$

$08 / 24 / 1999 \quad 52.9 \quad 48.6 \quad 59.2$

$08 / 25 / 1999 \quad 53.1 \quad 48.3 \quad 59.7$

$08 / 26 / 1999 \quad 54.8 \quad 49.9 \quad 62.0$

$08 / 27 / 1999 \quad 55.1 \quad 49.9 \quad 62.0$

$08 / 28 / 1999 \quad 55.5 \quad 54.1 \quad 57.2$

WFKCCR99-1S (W. FK. CHAMBERLIN CR.) MEAN MIN MAX

54.6

08/20/1999

$08 / 21 / 1999$

$08 / 22 / 1999$

$08 / 23 / 1999$

$08 / 24 / 1999$

$08 / 25 / 1999$

$08 / 26 / 1999$

$08 / 27 / 1999$

$\begin{array}{lll}50.6 & 47.1 & 53.5\end{array}$

$\begin{array}{lll}50.5 & 47.1 \quad 53.8\end{array}$

$50.2 \quad 47.1 \quad 53.0$

$\begin{array}{lll}49.4 & 45.7 & 52.7\end{array}$

$\begin{array}{lll}49.9 & 46.8 \quad 53.0\end{array}$

$\begin{array}{lll}49.8 & 46.8 & 53.0\end{array}$

$\begin{array}{lll}50.7 & 48.0 & 53.8\end{array}$

$51.2 \quad 48.0 \quad 54.1$

$08 / 28 / 1999$

$52.1 \quad 51.0 \quad 53.5$

ELK-5 (@ SUNSET HILL RD.)

54.6
52.5

\begin{tabular}{|c|c|c|c|}
\hline & MEAN & MIN & MAX \\
\hline 09/04/1999 & 50.4 & 46.7 & 55.6 \\
\hline $09 / 05 / 1999$ & 52.5 & 46.7 & 59.8 \\
\hline $09 / 06 / 1999$ & 53.5 & 50.3 & 57.8 \\
\hline $09 / 07 / 1999$ & 49.9 & 45.3 & 55.6 \\
\hline 09/08/1999 & 48.9 & 42.2 & 56.7 \\
\hline $09 / 09 / 1999$ & 49.5 & 42.5 & 56.4 \\
\hline $09 / 10 / 1999$ & 54.0 & 49.7 & 60.4 \\
\hline $09 / 11 / 1999$ & 49.8 & 44.5 & 55.6 \\
\hline $09 / 12 / 1999$ & 47.4 & 40.8 & 54.8 \\
\hline
\end{tabular}

52.6

50.6

ROCK-9 (ROCK CR. TRIB OF BBF)

\begin{tabular}{|c|c|c|c|}
\hline & EAN & MIN & MAX \\
\hline 09/04/1999 & 49.4 & 45.5 & 55.2 \\
\hline $09 / 05 / 1999$ & 50.0 & 46.0 & 55.8 \\
\hline $09 / 06 / 1999$ & 49.4 & 46.6 & 53.0 \\
\hline $09 / 07 / 1999$ & 48.5 & 46.0 & 2.7 \\
\hline 09/08/1999 & 49.2 & 44.9 & 55.5 \\
\hline 09/09/1999 & 49.7 & 45.5 & 55.2 \\
\hline $09 / 10 / 1999$ & 49.8 & 47.1 & 54.4 \\
\hline $09 / 11 / 1999$ & 48.8 & 45.8 & 54.9 \\
\hline $09 / 12 / 1999$ & 48.9 & 44.9 & 54.9 \\
\hline
\end{tabular}

LKS-10 (LOWER KLEINSCHMIDT @ MOUTH) MEAN MIN MAX

$\begin{array}{lllll}09 / 04 / 1999 & 51.6 & 46.9 & 58.8 & 52.2 \\ 09 / 05 / 1999 & 52.5 & 47.4 & 60.0 & 51.6 \\ 09 / 06 / 1999 & 51.9 & 48.2 & 56.0 & \\ 09 / 07 / 1999 & 50.8 & 47.4 & 56.0 & \\ 09 / 08 / 1999 & 51.4 & 46.0 & 59.1 & \\ 09 / 09 / 1999 & 51.9 & 46.6 & 59.4 & \\ 09 / 10 / 1999 & 52.3 & 49.1 & 57.7 & \\ 09 / 11 / 1999 & 50.9 & 47.1 & 57.7 & \\ 09 / 12 / 1999 & 50.8 & 45.8 & 58.3 & \end{array}$

MT-10 (MONTURE CR. @ MOUTH) MEAN MIN MAX

09/04/1999 $\quad 51.6 \quad 46.9 \quad 56.9$

$09 / 05 / 1999 \quad 53.3 \quad 48.0 \quad 60.0$

09/06/1999 $54.2 \quad 51.3 \quad 58.3$

09/07/1999 $51.8 \quad 47.7 \quad 57.4$

09/08/1999 $51.1 \quad 44.9 \quad 57.7$

09/09/1999 $51.6 \quad 45.5 \quad 57.7$

09/10/1999 $54.3 \quad 50.5 \quad 59.7$

09/11/1999 $51.7 \quad 46.9 \quad 57.4$

$09 / 12 / 1999 \quad 49.6 \quad 43.6 \quad 56.1$

RAT-11-99 (TRB OF CLRK FK)

MEAN MIN MAX

$09 / 14 / 1999 \quad 48.9 \quad 44.1 \quad 54.2$

09/15/1999 $48.8 \quad 44.1 \quad 53.6$

09/16/1999 $49.2 \quad 44.4 \quad 54.2$

09/17/1999 $49.6 \quad 45.2 \quad 54.4$

$\begin{array}{lllll}09 / 18 / 1999 & 49.7 & 45.5 & 54.4\end{array}$

$\begin{array}{llll}09 / 19 / 1999 & 48.7 & 44.4 & 53\end{array}$

$\begin{array}{llll}09 / 20 / 1999 & 47.4 & 42.7 & 52.2\end{array}$

09/21/1999 $47.8 \quad 43.3 \quad 52.5$

$\begin{array}{llll}09 / 22 / 1999 & 48.7 & 44.4 & 53.3\end{array}$

GOLD-1-99 (TRIB. BBLKFT)

MEAN MIN MAX

$\begin{array}{lllll}09 / 14 / 1999 & 47.6 & 42.9 & 51 & \mathbf{4 8 . 5}\end{array}$

$\begin{array}{lllll}09 / 15 / 1999 & 47.9 & 43.1 & 51.5 & 47.5\end{array}$

$09 / 16 / 1999 \quad 48.2 \quad 43.4 \quad 51.8$

$\begin{array}{llll}09 / 17 / 1999 & 49.2 & 45.1 & 52.1\end{array}$

09/18/1999 $48.7 \quad 44.6 \quad 51.5$

$\begin{array}{lllr}09 / 19 / 1999 & 46.4 & 42.3 & 49\end{array}$

09/20/1999 $45.4 \quad 40.9 \quad 48.7$

$09 / 21 / 1999 \quad 46.2 \quad 41.5 \quad 49.5$

$\begin{array}{llll}09 / 22 / 1999 & 47.5 & 43.1 & 50.7\end{array}$
49.4

48.8

53.4

52.1

48.5
47.5 
- 
